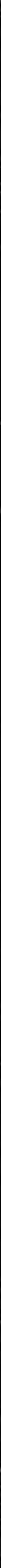



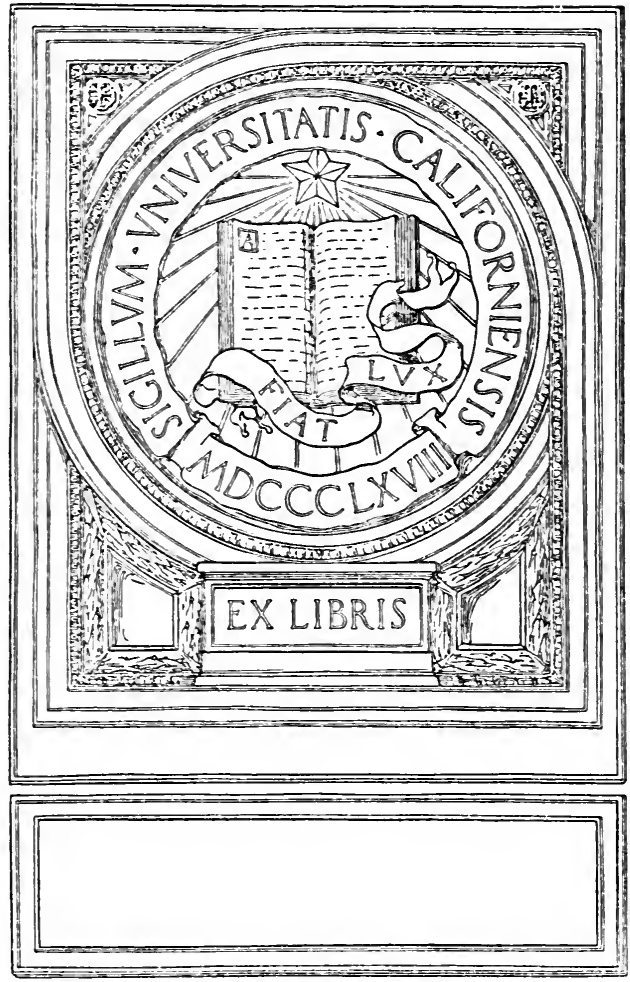

i) inalaed by the Internet Archive in $200-$ w th funding from 1. Microsoft Corporation

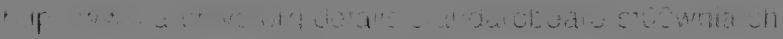




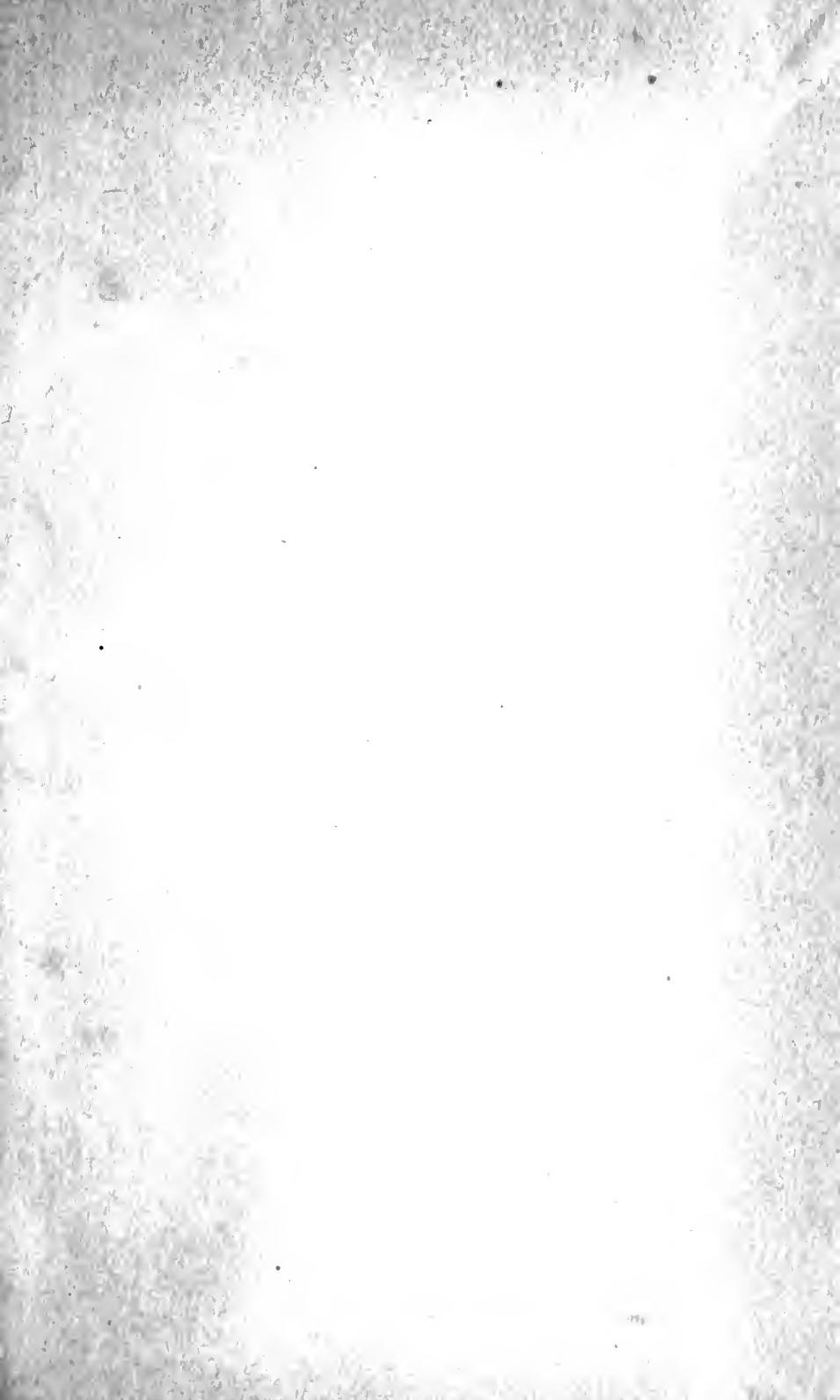






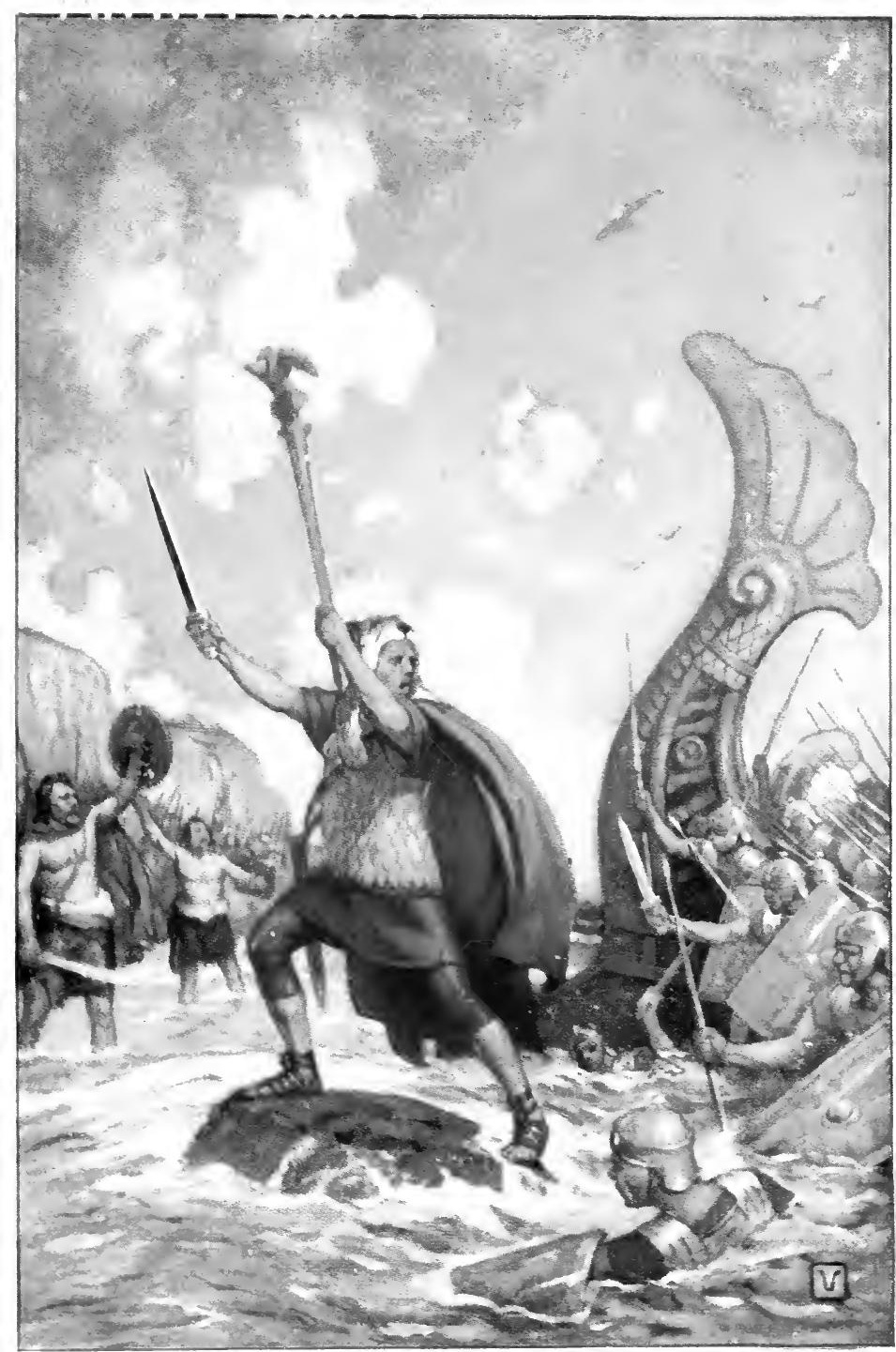

TH: STAXIARM BFARFR IFADS THF I,FCIONS 


\section{THE STANDARD BEARER}

A STORY OF ARMY LIFE
IN THE TIME OF CAESAR

BY

A. C. WHITEHEAD

INSTRUCTOR IN LATIN IN BOYS' HIGH SCHOOL ATLANTA, GEORGia

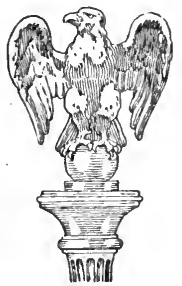

AMERICAN BOOK COMPANY 
$\therefore:: \because \because \because \because: \because \because \vdots \ldots, \because \because \cdots$

462

W59

st

Copyright, 1914, 1915

By A. C. WHITEHEAD

THE STANDARD BEARER

E. P. 3 


\section{PREFACE}

A cLAss of boys and girls whom the author was teaching some time ago, displayed more than ordinary interest in the study of the Commentaries of Cæsar. On reading the account of the standard bearer who so boldly led the legions at the first landing in Britain, the young people expressed considerable wonder as to the personality of that hero, making many conjectures as to his origin, his deeds in the army, and his promotion. It then occurred to the author that a story might be written which would give an accurate picture of the Gallic campaigns, and lend character, individual and national, to the chief actors. This book is an effort at such a story.

Much reading and study have gone to its making. While there has been a constant effort to portray the customs and beliefs of Romans, Gauls, Germans, and Britons, it is hoped that the characters and incidents are not hidden under loads of glaring facts as to customs and habits. The author further hopes that the story is presented in English which is pure and forceful, and in some degree, attractive. 
Cæsar and Baculus and Caius and Procillus and most of the lieutenants named are real actors in the Commentaries and may be further studied in the encyclopedias; but Matho and Sannio and Carvillax and Eredox and Lanius and even Bridiga are imaginary creations, and such character as they may have grew with the story. Should they fall short in any manner, it will in no wise be fair to blame Julius Cæsar.

If this book shall cause young people of the future to read their Cæsar with more profit and pleasure, the author will be amply repaid for his attempt.

Thanks are due my wife, Cora Brown Whitehead, and young son, Carlton, who very patiently read and criticized the chapters as they were written.

A. C. W.

Atlanta, Ga. 


\section{CONTENTS}

\section{BOOK ONE - PASTOR}

CHAPTER

I. The Shepherd meets a Proconsul • . . • . II

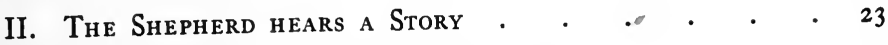

III. The Shepherd follows the Proconsul • $\cdot$. 33

IV. The Shepherd makes Acquaintances • • • . 42

V. The Shepherd becomes a Legionary • • • • 54

\section{BOOK TWO - MILES}

I. The Soldier has Adventures . • • • • • . 67

II. The Soldier hears a General's Speech • • • • 78

III. The Soldier savios himself by Flight • • • • $\quad .89$

IV. The Soldier fights in a Great Battle • • • 98

V. The Soldier asks a Question • • • • • • . IIo

VI. The Soldier in Winter Quarters • • • • • II7

VII. The Soldier learns of a Plot . • • • • . I I23

VIII. The Soldier in Battle with the Nervians • • • I3I

IX. The Soldier befriends a Nervian Youth . . 140

\section{BOOK THREE - AQUILIFER}

I. The Standard Bearer carries a Message • • • 147

II. The Standard Bearer has a Good Supper • . . I55

III. The Standard Bearer hears of a Distant Land • . 165

IV. The Standard Bearer refuses to write his Name - 170

V. The Standard Bearer leads the Legions • • 175

VI. The Standard Bearer hears a Tale • • • • I8I

VII. The Standard Bearer prepares for a Hunt • • • 188

VIII. The Standard Bearer is worsted by a Beast • . 195 


\section{BOOK FOUR - DUX}

CHAPTER

I. The Commander exercises Clemency . . . . 205

II. The Commander is attacked by the Enemy . . . 210

III. The Commander holds the Camp . . . . . . 214

IV. The Commander plays the Spy . . . . . . . 225

V. The Commander is made a Prisoner . . . . 233

VI. The Commander is not Sacrificed • • . . . 238

VII. The Commander fights and runs Away . . . . 246

\section{BOOK FIVE - VIR}

I. The Man meets a Glad Surprise • • • . . 255

II. The Man forgets his Motive . • . . . . 264

III. The Man sees a Great Siege Begun . • • 270

IV. The Man hears Another Story . • . . 275

V. The Man becomes a Lieutenant • • • . . 283

VI. The Man receives his Greatest Joy . . . . 290

VII. Conclusion . . . . . . . . . . . . . . 296

\section{APPENDIX}

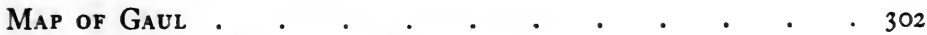

Pronunciation of Proper Names . $. \quad . \quad . \quad . \quad . \quad . \quad . \quad 303$ 


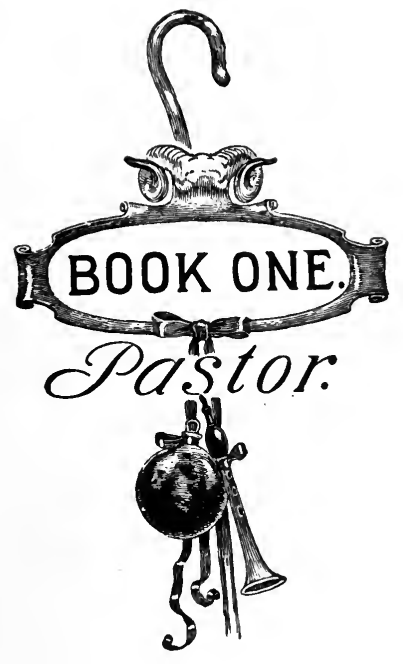




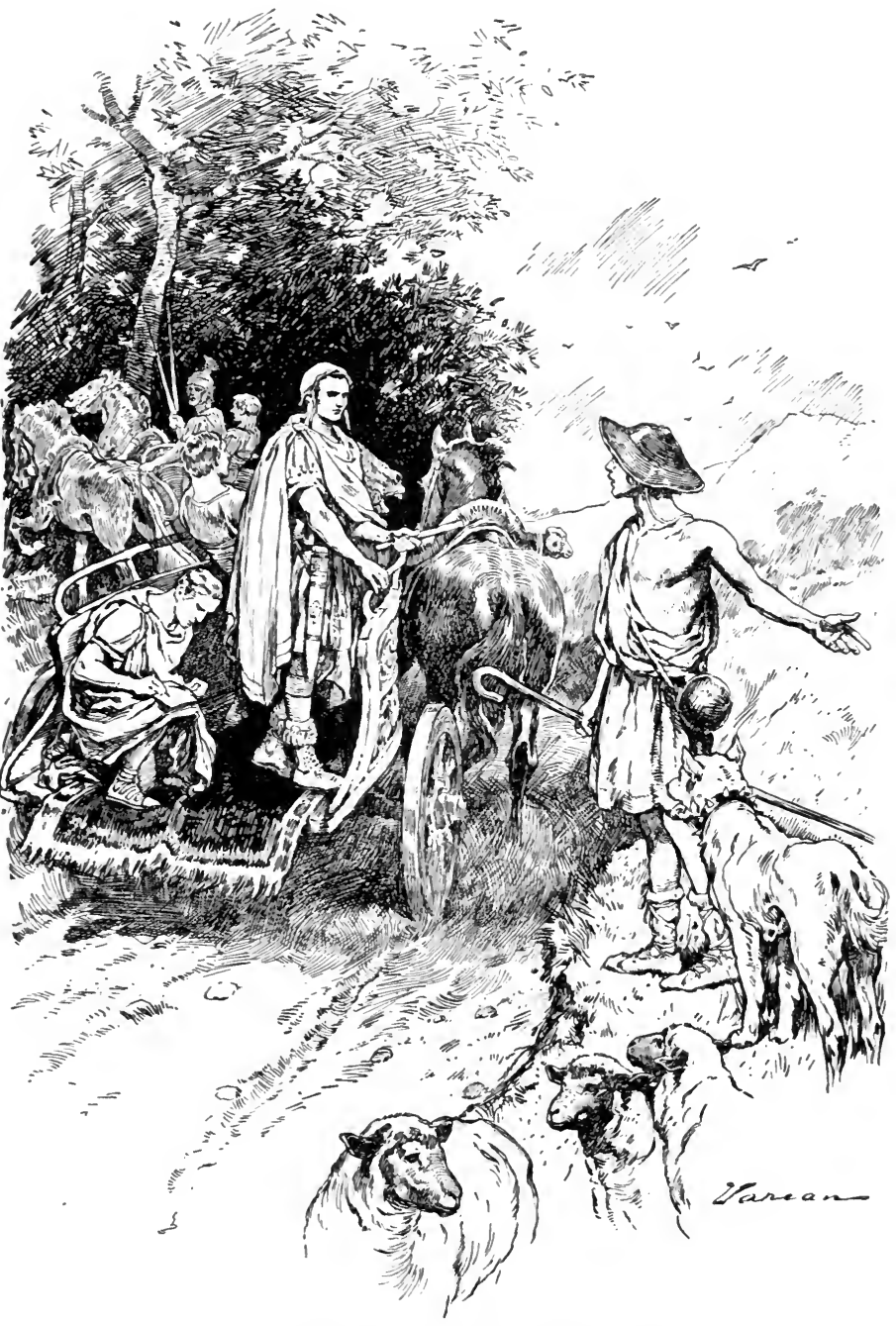

The Shepherd meets a Proconsul 


\section{THE STANDARD BEARER}

\section{CHAPTER I}

\section{THE SHEPHERD MEETS A PROCONSUL}

UNDER a spreading beech tree, on a grassy hillside, two youths whirled about each other with quick leaps and gasps for breath. Their faces were beaded with perspiration and their clothes as wet as though they had been dipped in the little lake at the foot of the hill. They had already struggled for some time in a wrestling match, and were still striving, each for the better hold to throw the other.

Suddenly, Caius, the taller and more slender, raised both arms as though he would enfold the arms and body of Titus, who was short and thick. To prevent this, Titus awkwardly flung up his own arms, which was exactly what the other had planned. Quick as thought, Caius rushed in and locked both arms about the big, round body of Titus. Then for a time they swayed back and forth, breathing hard and each doing his best to stretch the other at his length on the ground. Caius had the advantage of hold, Titus that of weight and age. Try as he would, Caius could not raise his heavy antagonist from the ground, for at every such effort, Titus threw his legs far back and planted his feet firmly, wide apart. 
Caius soon saw that if he won at all, he must do so by other tactics. He now began to strain with all his might toward his own left, and Titus, to keep his feet, pulled hard in the opposite direction. When Caius felt the opposing effort of Titus sufficient, quick as a flash, he yielded to the pull of Titus, and at the same time, threw his own right foot on the outside of Titus's left, thus blocking his chance at a firm footing. And so they fell heavily to the ground, Caius on top.

In the soft carpet of grass, neither was hurt. They rose, and now they might be more plainly seen.

Caius was tall and rather slender: seemingly about eighteen years of age, with a sunburned, frank, open face, pleasant blue eyes, and fair hair, and withal, an air of unconscious nobility. His companion was short, thick, and dark, with a stolid and rather surly visage. He was apparently somewhat older then Caius. Both wore wide hats, and short, armless, woolen tunics, the usual dress of Roman farmers, shepherds, and the like. On their feet were sandals held in place by means of leather thongs crossed and bound about their ankles and legs.

Caius now sat, or rather lay, under the shade of the beech, on which climbed a huge grapevine, hung with the odorous clusters of its white bloom, all alive with bees. The whole hillside was covered with the fresh, tender grass of early April, and sprinkled over with flowers - larkspurs, anemones, violets, and narcissus. At the foot of the hill lay a small lake, and beyond this stretched, far and level, the Via Flaminia, the great highway from Rome to northern Italy. On the margin of the little lake a small flock of sheep was feeding, guarded by a white shepherd dog, huge and fierce, 
and wearing a broad collar, thick set with three-inch spikes, a protection to the dog's throat against the attack of wolves from the mountains.

Titus had continued standing after he rose from the ground. "You did not throw me fairly," he grumbled. "Come, let us try again."

"No, not I," said Caius. "It is too hot, and I am weary already with trying to lift your big body. I wrestled just now only to please you, for I can scarce reach around you, and, with much more difficulty, throw you."

"Come on, once more," urged Titus stubbornly. "You know I must be learning and training, for I intend to be a gladiator like those who fight in the games at Rome."

"I mean to be a brave, strong man, too; perhaps a great soldier, maybe a famous general. Rome is good to her soldiers," said Caius. "But now it is hot. We may do our hopes harm by overexertion. We may wrestle again, perhaps leap and box also, when the sun falls lower and it grows cool. Let me pipe to you, now."

So saying, Caius took from a small bush where he had hung it a musical instrument called the fistula, made from short pieces of reeds of different lengths, and began to blow on it so gay a tune that Titus soon lay down on the grass, became more agreeable, and at last forgot to frown.

"Fortune is kind to you, Caius," said Titus when his companion had ceased playing. "You have old Simmias to teach you, and so you are well learned. You wrestle, leap, box, throw the quoit, and know 
music. Now here am I, a great lumbering fellow, anxious to do these things well, and yet I am awkward and clumsy in all. I suppose it is because I am a common rustic and have no teacher."

"Now, don't overrate my poor talents," answered Caius. "You have a big true heart as well as a great strong body, and I will ask mother to let Simmias give you lessons. I am sure you will soon learn as much as I know, for the sheep keep me too busy to learn much."

"No," said Titus, "I don't expect to learn as well as you, for my father knows when you and your mother came here. He says you are patricians. But if you are so good as to give me this chance, I will do my best what time I can be spared from the plow. Taxes and the robberies of our thievish neighbors keep me busy in making a living. Besides, this year old Meturio looked on our crops with the evil eye, and all our olives, figs, and barley have spoiled. But I shall find some time to learn. They say the gladiators are held in great honor and win much wealth at Rome, and if Simmias will teach me enough, I mean to go there to win my fortune and leave off fooling with crops on rocky hills. But what mean those birds flying at the edge of the wood beyond the pasture land?"

"Very likely a hawk has come down and is trying to catch a supper from among them," replied Caius.

"No, we should see the hawk as well as the birds," said Titus. "I prefer to think it a good omen for our future. See! They are flying toward our right. I am sure that is an omen - a good one for us who see it."

"I hope it is," said Caius. "But who made you an augur to interpret omens from the flight of birds?" 
"Well, no one made me an augur, but I know omens. Whether you believe that a good omen or not, this is certain: the sun is now far over toward the setting place, and that is an omen that night is coming. So I must run back to my work. Farewell."

"Farewell, till to-morrow," answered Caius.

Then Titus ran off down the hill, around the end of the little lake, across the road, on beyond, and soon disappeared around a line of gnarled olive trees that stood on the border of the field where he had left his work to seek the companionship of the young shepherd on the hillside.

Caius watched Titus out of sight. When he turned to look to his sheep once more, he saw his dog, Lucan, with bristles erect, angry and snarling, looking toward the wood where the boys had, so short a time before, remarked the flying birds. Turning his own eye in that direction, Caius saw two men coming toward him. They moved rapidly, and were soon near enough to be clearly seen. Both were clad in the common dress of working people, with the difference that the garments of these two were of cloth striped with gay colors - red, blue, and green. They wore besides a sort of loose trousers of the same varied colors. Each carried a large sword, old, rusty, and gapped, slung from his shoulder by means of leathern straps. Each appeared to be about sixty years of age, with gray hair and beard, longish stolid face, and fierce blue eyes. Snag-toothed, unkempt men they were, rough, harsh, careless and reckless.

"It was they who frightened the birds," said Caius to himself. "Truly a bad omen for me, I fear." 
Meantime the two men came up, while the dog took position as near as possible between Caius, the sheep, and the two men, showing his long, sharp, white fangs, and snarling fiercely.

"Come, boy, keep your dog quiet, now," said one of the men. "We want only a sheep or two to celebrate the great victory of Chæronæa, where we won much glory under old Sulla - may all the Roman gods keep him!"

"What will you pay me for the sheep:" asked Caius.

"Pay ? We don't pay for anything we want, not we, old soldiers of Sulla. So keep your dog back. The less noise you make, the quicker and easier will all be over." So saying, they unslung their swords and advanced toward the sheep.

But Caius had no intention of giving up any of his flock without an effort to save them. He was now moving down the hill toward his sheep, his long, heavy wooden shepherd's crook in hand.

"No trouble, now, my boy. Let us have the sheep and we will be gone shorty and out of your way," answered one.

"You shall not have them unless you pay me their value," said Caius.

"All right. We have given you fair warning. We shan't pay, but we shall take the sheep. At them, Eredox," he cried, "and cut down three or four of the best and fattest. I will keep the boy and the dog away."

By this time the men, Caius, and the dog, all moving down the hill, had nearly reached the flock. Old 
Eredox made a dash and tried to kill one with his sword, but gentle as they were, they all took fright at this, and scattered, scampering helter-skelter among the hedges and hillocks. The dog had quickly seized Eredox by the calf of the leg, and with a great surge, dragged him to the ground, just as Eredox slashed at him with his sword. The dog adroitly dodged this

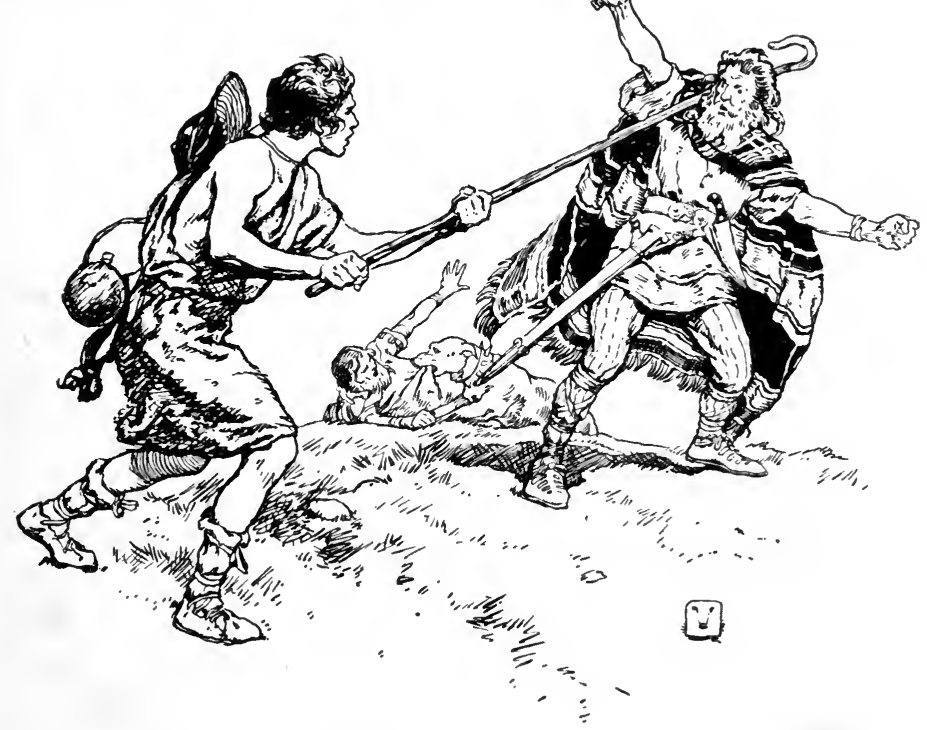

blow as well as a second which the other robber rushed in and aimed at him.

Caius meanwhile lunged and struck heavily at the one who had agreed to stand guard. The latter parried this blow, at the same time hurling himself at Caius and aiming a cut with his long sword. This 
Caius barely evaded, and was only saved from another by the dog's fierce attack on the man. But the dog came in now for a savage slash which would have cut his head clean off his body but for the thick, wide collar with its iron spikes. As it was, the faithful animal was stretched at his length on the grass.

Eredox being now up again, both robbers charged furiously upon Caius, who retreated slowly before them. Old Eredox, fairly foaming with rage, came on ahead of the other, howling and swearing and slashing like a madman. Caius watched his chance and skillfully laid a sounding knock on his head with his heavy staff. Seeing the man stunned, with a second quick blow, he knocked the sword from the hand of the old rascal, who yelled with pain and fell back out of reach.

The other of the two was just coming up to Caius, when now was heard in the distance the roar of chariot wheels and the hammering of horses' hoofs on the hard, stone-paved Via Flaminia. The two robbers at once ceased their attack to look in the direction whence the noise came. A single glance was sufficient to show them, moving swiftly forward along the great Roman road, several chariots in which, under the rays of the late evening sun, appeared the glow of burnished brass, the flutter of Roman standards, and the clear white glitter of the polished steel points of armed men.

The old rogue who still retained his sword took to his heels. Eredox was just on the point of following, when Caius gave him a final whack on the head, and the dog, now recovered, seized him by the throat, and with a fierce snarling and growling, dragged him down. It was with difficulty that Caius prevented the enraged 
brute from tearing the man's throat into bloody shreds, and he succeeded in pulling the dog off only just as the chariots came up and stopped in the road, by the little lake.

A man in the second chariot from the front at once called to Caius to come down to the road. Not knowing what else to do, Caius signaled to the dog to follow, and obeyed. Old Eredox quickly sprang up and ran away, leaving a red trail on the green grass, for Lucan's teeth had left his throat ragged and bloody.

"What was the trouble?" asked a second man in the chariot, as Caius approached. His voice was wonderfully clear and low, dignified yet friendly - a tone which implied also that he had small time or temper to listen to useless details.

"They were trying to take my sheep," answered Caius. Then led on by the stranger's kindly look of inquiry, he briefly related the occurrence. While doing so he had opportunity to observe his questioner - a man about forty years of age, somewhat tall, not stout, and yet not a weak line in his whole body. He wore a white tunic of richest material, and over this was thrown with a seeming carelessness that gave a touch of grace rather than of negligence, a short scarlet mantle, edged with gold, and caught together on the left shoulder with a jeweled clasp. On his head he wore a soft traveling cap and he was shod with pliant leather sandals. His face was rather pale. A large nose, full firm lips, and dark piercing eyes were overhung by a forehead, broad and high. There were lines and seams, too, of power and set purpose. All together he was a man whose quick and vivid energy, bold deter- 
mined will, and masterful intelligence caused Caius to feel at once that he would love and respect this man friendly to him, and would hate and fear him hostile. The young shepherd knew by instinct that he was in the presence of one who would spare none of his vast energy in executing the far-reaching plans which his august and massive intellect might conceive and his inflexible will determine.

He heard Caius to the end and then said, "You fought well, but it is perhaps fortunate that we came. Now, what is your name?"

"Caius Volcatius Tullus," answered the youth.

The man started with something like surprise and, dropping his eyes, seemed trying to call to mind something long forgotten. But this action occupied only a moment. "Caius Volcatius Tullus," he mused, looking now hard at Caius. "Well," he continued, "we have the same name, at least in part. Perhaps this is a good omen for you or for me, perhaps for both. My name is Caius Julius Cæsar."

The young shepherd stared in astonishment. He now knew what he might have known from the bright red cloak, had he been better versed in the meaning of military dress, that this was a general. .From current rumor, he was informed that this was the proconsul to Gaul. He knew, too, that this man was reputed the favorite of the Roman populace. Caius stood speechless, not knowing what to say.

Meanwhile, noting the broad chest, muscular arms, long slender body, and sinewy calves and feet of the youth, Cæsar continued, "You have the certain marks of a good soldier. Would you like to be one?" 
"Nothing would please me better," replied Caius.

"Good," cried Cæsar. "Will you go to Gaul with me and learn?"

"Sir," answered the boy, "I would gladly do so if my mother could spare me. But I fear I must remain at home with her, as she and I live alone except for. old Simmias and his wife. She needs me to care for the sheep and olives."

"Caius, I should be pleased to have you go with me, if you wish it and can arrange for the care of your mother. A body of my soldiers will pass this way tomorrow. I will give you a note to Quintus Pedius, their commander. They will spend the night at yonder village of Spoletum. Join them there if you can," said Cæsar. Then he added to a third man in the chariot, "Write the note to Pedius concerning the youth, and quickly, for we must proceed."

The secretary, for such he was, rapidly wrote on a small piece of parchment, folded and tied it around with a slender linen thread, and sealed it with a small piece of wax on which Cæsar stamped the impression of the seal which he wore on a chain. This note was handed to Caius. Then at a word from Cæsar, the company dashed forward on the highway toward Ravenna, the seat of government of Cisalpine Gaul.

In amazement at this sudden fortune, Caius gazed after the warlike troop with its pennons, crests, and togas floating in the breeze that now stirred. A chance to go to Gaul in the army of Caius Julius Cæsar, the idol of Rome!

But now the bleating of the sheep suddenly brought his thoughts back from the glories of future wars to 
the duties of present peace. "Come, Lucan, gather the sheep," he said, to the dog; and blowing a peculiar call on his fistula, he soon had the sheep collected.

The sun had now set in a bank of fire, leaving the sky and fleeting clouds a glory of shining gold and glowing tints and sparkling gems. Crickets were chirping, and frogs began to croak and chatter on the margin of the little lake. So Caius, seconded by the dog, led the sheep past the tree where he had wrestled and piped, along by the barley field bordered with fig trees, to the little home over which three tall, longarmed cypresses kept guard.

The sheep were soon disposed of for the night, and then with brain awhirl and heart afire with excitement and hope, the youth went into the house. 


\section{CHAPTER II}

\section{THE SHEPHERD HEARS A STORY}

Camilla, the mother of Caius, was waiting for him. She was a handsome and portly Roman matron, of a quiet, dignified mien. "Caius, you are late," she said as he approached. "Has anything happened?"

"Yes, mother," he answered calmly, not willing to alarm her. "But I am not hurt, and no harm is done."

"I am glad all is well," she said. "Your supper is waiting. Come, eat first, and afterward you shall tell me all."

Then with her own hands, Camilla waited on her son while he ate a meal of coarse barley bread, milk, curd, and some dried figs. But the supper was soon finished, for Caius in his eagerness to tell his mother the occurrences of the evening could hardly wait to satisfy his boyish appetite.

When he had finished, he sat near her on a small wooden stool and related to her the attack of the robbers on the sheep. To this she listened with indignant anger. However, she said nothing. But when he told of the meeting with Cæsar, she felt a delight she could not conceal.

"Why do you smile and look glad, mother ?" inquired the boy. "Is it because you wish me to go away to be a soldier?"

"I will tell you something, first, Caius," she answered, "and then you will know why I smile, and you yourself 
shall decide whether you will follow Cæsar to Gaul, or not."

Then, while Caius listened with wide-eyed and breathless interest, Camilla began: "Your father was of a noble and ancient family in Rome. He was handsome and brave. He was educated in Greece, and loved his books. But wars came on, and he left his books and study to serve as a lieutenant in the army of Caius Marius against Jugurtha in Africa. He also fought with Marius against the Cimbrians and Teutons when those dreadful barbarians seemed likely to overrun all Italy with fire and sword. During the battle with the former in the Raudian Plains his left hand was shorn off by a huge, long-bearded, red-headed Cimbrian giant. After this he retired from the army, he and I were married, and we lived at Rome. He gave his time to the management of his three farms in other parts of Italy, and to the reading and study of his books. We were very happy, especially after you came.

"Meanwhile, the soothsayers predicted direful events to occur in Italy and Rome. For it was reported that fearful prodigies had appeared in various places. A cow in Campania was heard to speak the words, 'Danger and Death.' At Rome the statue of Tiberius Gracchus was observed to shed tears which ran down the face and became drops of blood. Also a spear in the hand of the statue of Mars moved with a great rattle and clangor. By order of the consuls, a sacrifice of larger victims was made. But despite sacrifice and prayer to the gods, all the time a dark cloud was gathering over Rome which would shut out the sun of prosperity and happiness from us and thousands of 
others. The struggle for supremacy between Marius and Sulla was on, waxing ever more bitter as their mutual hatred grew more violent. When Sulla had once come to power, he put to death some of the friends of Marius. Later, Marius came to rule Rome and he had large numbers of Sulla's followers cruelly butchered by freed slaves. And thus their passions grew more deadly. At last Sulla returned victorious from his wars with the great Mithridates in the far East. He defeated all the Marian armies in Italy, took possession of Rome, and at once coolly set about a terrible reckoning. He first massacred eight thousand captive Marian soldiers in the Circus."

Camilla stopped, seeming to recoil from the relation of the horrors that followed, but, led on by the intent silence of Caius, she continued: "All Rome was in alarm. Most citizens remained at home unless duty called them out. Your father, conscious of having done no wrong, continued to come and go about his business. A day or two after Sulla had entered the city, he returned home early. His face was troubled, and in reply to my questions, he said that Rome would quickly be drenched with the blood of her own citizens. He said that Sulla had nailed up in the Forum a long list of those who had opposed him. Pardons as well as rewards were offered to any who would kill those named on the list.

"Your father had hardly told me these things, when we heard a piercing scream that checked the blood in our veins and almost stiffened us-with fear. We rushed to the door, and looking forth across the street, we saw Cornelia, the wife of Lucius Curo, fallen forward 
on the dead body of her husband in an agony of grief, while strutting away were three insolent soldiers, one carrying in his hand the head of Curo, ghastly and dripping blood. A little farther on we saw them attack another Roman knight. Your father was in the act of rushing out to give him aid, but I held him to me so

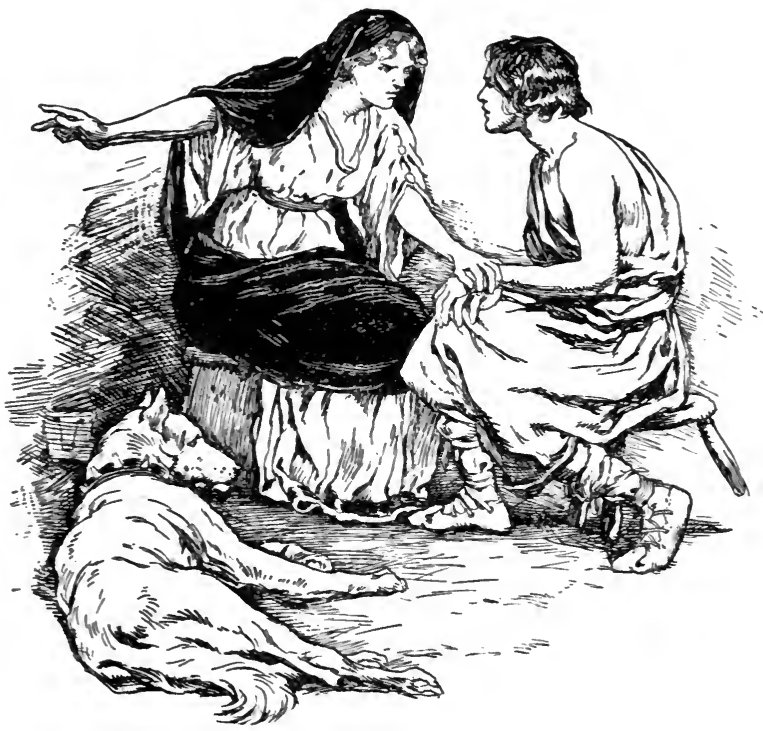

he could not. I feared to bring the ruffians upon our house. Horror drove me into the innermost parts of our house, but the walls could not shut out the screams and shrieks of terror-stricken women and children as they beheld some relative stabbed or saw his head shorn off. The slaughter went on all that day and did not cease with the coming of night.

"The next morning a longer list of names appeared 
in the Forum. Then it was said that the property of those put to death was to be given to those who executed them. Everywhere, now, could be seen bands of soldiers and rude Gauls hired for the purpose, roving the streets and slaughtering, while on every side the cries and shrieks and moans of the wretched victims pierced our ears.

"Pale fear laid her hand on man, woman, and child. Every one began to plan how he might most surely save himself. Many with old grudges contrived to get their enemies' names on the black lists, and thus to rid themselves of those they feared or hated. The avaricious got the names of the wealthy on the lists and then claimed their houses, villas, and lands. The wife of one of our neighbors betrayed her husband. She soon got his property. A friend of ours, Mutilus, found his own name upon the list. He fled. Then at night he came disguised to the door of his wife's house to beg for comfort and protection. With abuse and curses she told him he was a forbidden man, no better than a corpse. She refused to admit him. And there on her threshold, he stabbed himself and sprinkled her door with his warm life blood. And so the madness raged. Lifelong friends were given up, and lovers betrayed each other. Husbands saved themselves by reporting their wives, and mothers by handing over their daughters. Fathers betrayed their sons; sons, their fathers. Most incredible to relate, a mother, one Crispina, gave the prætor her son's name as a traitor to Sulla, and he was beheaded before her eyes. So none were safe and all to be feared, and the black list grew day by day. 
The streets presented a horrible spectacle. In one place so many men were butchered that streams of blood flowed on the rough stone pavement like water in a spring flood. The dead lay unburied, and the stench was like that of a battlefield. Headless, bloated, blackened bodies floated on the yellow waters of the Tiber. Vultures swarmed and dogs slunk about in packs, and glutted themselves on putrid flesh torn from the limbs of Rome's proudest patricians. In the Forum were pyramids of human heads, with the glazed and sightless eyes staring unseeing through tangled, bloodclotted mats of hair. On the main streets stood rows of upright spears, each topped with a head, grinning and horrid.

"Most of our servants, overcome with terror, left us. But Simmias remained true to the last. He kept about his duties as though nothing unusual were happening. Your father, also, came and went freely on the streets, but under a secret dread. At length, one day, he returned home toward night and said that he had, by chance, overheard Marcus Bassa, who was an old personal enemy, and another man speaking of your father's having served under Marius, and what was of more importance to them, he had a large amount of property. We were now much alarmed, knowing full well that his name would be on the list next day. So we began at once to make hasty preparations for leaving Rome. But we had hardly set about the task, before three villainous-looking Gauls who had stealthily followed him appeared, and in barbarous accents called for him to come forth. He felt that there was no escape, and so like a brave man, he presented himself, 
sword in hand. The men began to quarrel in Gallic fashion, as to which should attack him first, and he, quickly seizing the opportunity, stabbed the first who came near, and wounded the next, but meanwhile the third had run behind him and thrust him through the back. He fell in a great pool of blood. A dizzy, sickening horror almost overcame me, but I caught you up and tried to run.

"Just then Simmias entered, returning from the market place. 'We must fly,' he said. He and Chloe quickly dressed me as a servant. It had now grown dark, and we went out into the street by a back way. No one molested us, and we hastened toward one of the breaches in the wall that Sulla had made when he took the city. Simmias carried you, a babe of two years, in his arms, while Chloe and I hurried after him. As we neared the place, close by the temple of Neptune, we found ourselves approached by a chariot, the occupant of which, in a low tone, called Simmias by name. Then we were almost frozen with fear, thinking we should be arrested, but there was no chance to escape. Simmias answered, and we found that the occupant of the chariot was none other than Julius Cæsar, then a priest of Jupiter, and a friend of your father's.' He had recognized Simmias in the dark, and, fearing some evil had befallen the family, he had called him. Our story was quickly told. Cæsar, too, was leaving Rome, seeking safety in flight, because he had refused to divorce his young and beautiful wife at the command of Sulla.

"Cæsar took three of us - Chloe, you, and me - into his chariot, and Simmias followed on foot. Instead of 
going on to the breach in the wall through which Simmias had expected to steal with us, Cæsar boldly followed the street leading to the Flaminian gate that opens on the Via Flaminia. At the gate, a soldier on guard challenged him. "A priest of Jupiter with his servants going forth into the country," carelessly answered Cæsar, and we were allowed to pass without further question.

"Once out upon the road, it was agreed that Cæsar should take us to this little farm which belonged to your father, while Simmias was to follow as best he could. Then Cæsar drove rapidly northward, and lodged us here safely. Cæsar went his way. He has since, as you know, climbed to place and power at Rome.

"We were very lonely here and had to live very hard. Soon rumors reached us that our home at Rome had been given by Sulla to Bassa and his associates, and our other property had been confiscated. The next year Sulla settled many of his legions in towns in various parts of Italy. One legion composed largely of Gauls was settled at Spoletum, here right at us. Many citizens of the place had supported Marius in the struggle with Sulla. So their lands were given to these old Gallic soldiers. The large farm with the handsome villa that lies between here and Spoletum was ours. It, too, was taken and given to these hated Gauls. Our last hope of a comfortable home was thus removed, and we were left only this poor little farm, and worst of all, we were almost surrounded with rough soldiers, men who knew no law and feared nothing, and who, worst of all, would be our enemies, should they once find out who we were. 
"I do not know how it was, but this little farm was overlooked when the rest of the property was confiscated. So we have dwelt here. Simmias and Chloe have remained with us and have been faithful beyond all belief. As you know, he has taught you and cared for you as a son, while Chloe has been, though a servant, almost a sister to me."

"Mother, why have you never told me these things before?" asked Caius when his mother had ceased.

"Because, Caius, as we were surrounded with these Gallic soldiers, among whom, perhaps, might be the very one who had robbed your father of his life, I feared your pride in the matter might lead to trouble with them. We have never been molested further than by an occasional robbery. But if they had once found out who we are, they would likely have given us a great deal of care. They have always believed that we are only plebeian farmers."

"I wish now that I had let Lucan kill the old rascal called Eredox this evening," said Caius, his face white with grief and rage. "Mother, may I go with Cæsar and learn to be a soldier? Perhaps in some way I may be able to recover something of what we have lost."

"Yes, my son, now that Cæsar has opened the way for you to a soldier's career, I am glad, and you may go. I believe you can win new honor for the old name, and above all, avenge your father's death. I will make any sacrifice for you to go. Cæsar is a man of power, is just, and a friend of the people's rights.'

Caius was so touched by the knowledge of what his mother had lost in life and the suffering she had en- 
dured, that he had no words to express himself. So he was silent. Boylike, he was glad, too, that he could become a soldier with his mother's consent. But after a time, he said, "Mother, I shall go. I will do all in my power to win fame and fortune in order that your life may be more happy than it has been here."

"Caius, I have been happy here in seeing you grow large and strong, and in the hope that times will change. I grieve sorely to part with you, but I feel sure it is best for us both. So, go."

"I will," declared Caius. "And you shall have no cause on my part to regret sending me. I think Titus will keep the sheep, and I can give him a part of my pay as a soldier. Besides, he is eager to learn, and if you are willing, Simmias shall teach him."

And so mother and son made plans late into the night. 


\section{CHAPTER III}

\section{THE SHEPHERD FOLLOWS THE PROCONSUL}

After Caius had retired to his straw bed, he lay long awake. He tried to rest first on one side, then on the other, but his mind was in such a fever of excitement that sleep would not come. Now he grew hot with anger at the memory of his fight with the hateful Gauls who had tried to rob him of his sheep; then he thought on the face and form and words of Cæsar; and next, visions of future glory as a soldier flashed upon his mind's eye. Then he ground his teeth with rage at the thought of his father's being slaughtered and lying unburied, and it seemed his heart must burst when he realized the poverty in which his mother had been compelled to live all these years, when the best that Rome could afford should have been hers.

Over and over again these thoughts chased each other in his brain, and over and over again he turned his body. At last all grew confused and he knew no more until, suddenly, it seemed that he and Titus were down under the shade of the old beech tree, about to cut a melon with a big knife. Then in a flash the scene changed, and old Eredox was standing over him just ready to hack off his head with the old gapped sword. He could actually feel the rusty blade sawing on his neck, when, with a jump and a gasp, he awoke, glad to find it was only a dream.

A bar of sunlight was falling in his room, and so he 
hastily got to his feet and dressed. Indoors his mother and Chloe were busy about household duties, while outside Simmias was feeding the cows, chickens, pigs, and pigeons.

"Simmias, you didn't know that I am to be a soldier?" cried Caius, as he hurried into the yard.

"No," replied Simmias, rather glumly, as Caius thought. "Your mother has just now told me and Chloe of your chances and your plans, but I think you had best stay here and take care of her. The robbers may take all the sheep and olives, too, if you are not here."

"Now, I know you too well to believe you think any such thing," said Caius. "I am sure you will be glad for me to go if it is possible. I know, too, that you and Chloe will take good care of mother for me, especially if Titus will keep the sheep."

"You are right, Caius. What you say is only too true," said Simmias, sadly. "I am anxious that you go, though I grieve more than I can tell to give you up. When I think of all that your father's family has suffered, and I and mine with it, I am only too glad for such a chance to come to you. So you had best run over at once, and see if Titus can stay with us. If you are to leave us to-morrow, there is much to do to get you ready."

Then Caius hurried away, down the path by the old beech, past the little lake, across the highway, and beyond to the house on a small, stony hillside farm, where Titus lived with his father. A fresh wolf's head grinned at him from the big cypress tree before the house. 
"Hello, Titus," shouted Caius coming up.

"Where did you get the wolf's muzzle?"

"Father killed one yesterday," said Titus. "The head will keep away the witches."

"Well, at any rate, I have good news," said Caius. "Sure enough, the birds were for a good omen. A bad one for me, though, I thought at first; but it turned out to be a good one for me, and you, too, I hope."

Titus continued stolidly yoking his oxen to go to his plow. "What has happened now?" he asked carelessly.

Then as Caius told him about the robbers, Titus grew visibly interested. Finally his jaw fell lower, and he stopped his work, stood and listened hungrily, and a great frown ridged his forehead. Meanwhile he was knotting his big fist and drawing himself into a wad. "Why didn't you call me? I wish I had been there," he muttered. "What a chance for practice to become a gladiator!"

"A gladiator I see you are bound to be, sooner or later," said Caius. "But I had no time to call you. Besides, Lucan and I kept them busy enough, I think. I have come now to beg you to be something other than a gladiator for the present." And Caius proceeded to tell the other of the meeting with Cæsar and its result.

"Fortune is certainly good to you, as I said yesterday. Why could not I have had this chance to be a soldier?" grumbled Titus. "Well, so you want me to stay here at home and keep your sheep while you go abroad with the great Cæsar to be a soldier in Gaul? I won't do it. I will go to Gaul myself," he affirmed stubbornly. 
"But, Titus, it was not you that Cæsar asked to go. Besides, I think you forget that this is just the very chance for you to learn from Simmias what we were talking about yesterday," argued Caius.

"Yes, but this is not like being in a legion and fighting in real war," returned Titus. "But perhaps my chance will come some time," he went on. "So I will try to keep your sheep if father will let me. Come on, we will ask him."

As old Pullo had a large family to feed and clothe, and no very great income from the rocky little fields, he decided he could spare Titus for the money Caius promised; and therefore it was soon arranged.

Titus went home with Caius, and with his aid and instruction was soon prepared to take charge of the flock. Old Lucan, as well as the sheep, seemed distrustful and displeased. The faithful dog appeared in doubt whether he should throttle the new shepherd or obey his strong-voiced orders. But he finally showed by his actions that he understood, and so went off to. the hills with Titus and the bleating sheep.

Nearly all day, Caius's mother, with Simmias and good motherlike Chloe - who took it all quite as hard as Camilla - were busy making him ready for his departure. It was hard for Caius to do much except watch the road to which his eyes constantly turned, though he knew that Cæsar had said it would be nearly night when Pedius would pass. But the preparations were finally completed, and at last, about sundown, he saw a body of horsemen and chariots flash by with a clatter and rumble, and on toward Spoletum, a half mile beyond. By their standards and armor, Caius 
knew these were the men with whom he was to travel to Gaul, and that they would stop for the night at Spoletum, as Cæsar had so appointed.

Despite his loss of sleep the preceding night, Caius could hardly close his eyes, so excited and eager was he. An hour before day, he was up, dressed in his best, which was only a clean shepherd's cloak. Then, after a farewell to his mother, Simmias, Chloe, Titus, and even old Lucan, he set forth briskly in the dim light and fresh air of the early dawn.

By rapid walking, Caius reached Spoletum just as it was light enough to begin to see well. He went directly to the inn where he thought it most likely the lieutenant, Pedius, had spent the night. Before the door in the yard, he found several horses and chariots being made ready for travel. A number of young men in bright armor and plumed helmets stood and stamped about, seeming fretted at the delay. The one nearest Caius as he came up - a young man of medium size, with heavy body, thin legs, a back-slanting forehead, dark face, and sneering eyes - stood carelessly leaning against a horse richly trapped. Caius asked this youth where the lieutenant, Quintus Pedius, might be.

"The lieutenant, Quintus Pedius," mocked the young Roman. "And what has a rude shepherd from the hills to do with the lieutenant, Quintus Pedius, I should like to know."

"I have business with him and must see him," replied Caius, hotly, for he was stung by the insulting manner of the other.

"Ah, rather warm for one of so gentle a calling," calmly smirked the Roman. "Perhaps you come as 
ambassador of the sheep to report to Pedius that those worthy folk have been furiously attacked with hoof and horn by a band of bellicose goats, and to ask aid."

A wink and a smile from some of the others greeted this far-fetched sally, and Caius was betrayed into a fury by a cool insolence, such as he had never met with

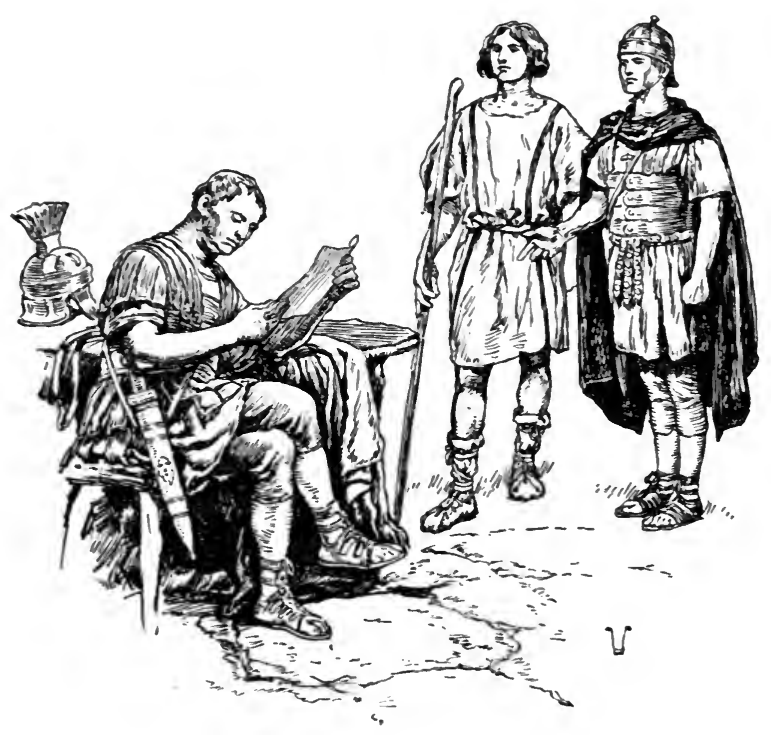

before, and so he quickly returned, "I am to be a soldier, and you shall not mock me."

"Ah! Perhaps you mean to conquer the goats. I see your helmet shows signs of fierce battle, already," drawled the other, glancing meaningly at Caius's hat, which was old and worn.

Caius firmly grasped the heavy staff with which he had set off from home, and was on the point of charging 
upon the young man who had so causelessly insulted him, when one of the others spoke. "Don't tease the youth, Lanius; enough has been said." Then he added to Caius, "Good youth, present yourself to the guard at the door there. If you can show sufficient cause, he will admit you to Pedius."

Caius at once followed these directions, and was soon admitted to the presence of Pedius, a stout, middleaged man, of no extraordinary appearance, dressed in a short-sleeved, red-bordered sort of shirt, belted about his waist and reaching nearly to his knees the usual dress of a Roman legatus, or lieutenant. He was alone at his breakfast, and received Caius while busy at this meal. He read Cæsar's note and looked at Caius with some interest.

"You are in luck, young man," he said. "Whom Cæsar favors, Fortuna smiles upon. I am commanded to take special care of you. Well, you shall ride in one of the chariots, and when we reach Ravenna we will provide a more suitable dress for you. We set forward at once. Be ready." And he dismissed Caius, after giving an order to the legionary soldier at hand to direct the youth to the vehicle in which he was to travel.

It was now bright daylight. A trumpet sounded, arms and armor clinked and clanged with the sound of men taking their places in saddle and chariot, and the troop set forward out of the little town toward Ravenna. As the party rattled along, people gathered in the doorways and streets to see them. At a small house near the outskirts of the place, Caius thought he recognized old Eredox leaning against the doorpost, his neck 
thickly wound with a dirty cloth. He quickly dodged within as Caius passed. But as Caius looked back, he saw the youth Lanius wave a hand toward the house, a motion that seemed to be one of recognition. For a moment he wondered at this.

But as they traveled onward his mind was quickly removed from this subject by the talk of one of the men with whom he rode. This was Sannio, a jovial, goodnatured soldier of middle age who found something at which to laugh in everything that happened.

"The men in the chariots," he told Caius, "are mostly soldiers and lower officers. Those on horse in brass armor are hardly soldiers at all. They think they are going on a holiday-sort of fair-weather friends of Cæsar's, who are following him to Gaul, expecting to have a good time and collect a lot of valuable plunder. But they won't think so long, under Cæsar. If they were real soldiers, they would have good steel armor instead of this brass floppery. But they want something bright and costly. True Roman fighters have not been accustomed to wear brass for these hundred years. These gay young gentlemen will soon learn better, too, if they can be coaxed or driven into a battle. Some of them think they are knights. No older than I am, I knew some of them when their fathers were butchers, wine merchants, mule drivers, and the like. The occupations, mind you, young man, are all right, but they don't change dandies into patrician knights by any means. For as the proverb goes, one born in a garret does not fit a palace. Now, I was born in the country. My father was a freedman farmer. But he was plain and honest. 
He brought me up in the same way. I believe in the gods and worship them all, whether they dwell in the wood, field, sea, or sky. I know there is no profit or fitness in making as though you are what you are not. If I should try, as some of these upstarts, I'd look as foolish as a mule on a housetop." And he laughed, well pleased with his wisdom.

And so they traveled, over the Apennines, down into the plains of Umbria, and on to Ravenna. 


\section{CHAPTER IV}

\section{THE SHEPHERD MAKES ACQUAINTANCES}

Авоuт sunset of the second day after leaving Spoletum, the detachment of Pedius went clattering into Ravenna, a small seaport on the Adriatic. The road led near the seashore and was thronged with shouting sailors, hawking peddlers, silent merchants, sturdy soldiers, and gazing travelers, jostling and pushing among each other.

As the Roman party appeared, all made way for it, and it dashed onward through the crowd. Upon looking down the streets to the right, Caius saw that they seemed full of water. "How is this?" he exclaimed to Sannio. "Has a flood filled the streets?"

"No," laughed Sannio. "Ravenna is built partly in the water. If you wish to travel one of these streets; you go in a boat instead of walking or taking a chariot."

Caius, Sannio, and two or three others were sent, by the order of Pedius, to lodge for the night at a small inn on the northern side of the town. After their fat, darkfaced host had assigned them their quarters, Sannio said to Caius, "My young friend, Pedius has commanded that I go with you to a merchant and buy suitable clothing for a soldier. Let us forth and do this before we eat."

"Well enough," replied Caius. "But I shall claim the right to pay for them."

"I have orders to buy them at Cæsar's expense," 
said Sannio. "So there's an end to all discussion of the matter."

"Well, I shall keep an account of the cost against a day of settlement," said Caius. "I have little money, but neither Cæsar nor any other man shall pay for the clothes I wear."

"Keep all the accounts you may, young Proudheart," said Sannio. "I fancy you will have opportunity to pay for all you wish, if you are to be a soldier. Most of them end every year with exactly as much money as they have when they begin it - which is none."

They had now reached the end of an earthen street leading toward the sea. They entered a small boat, poled by a stout boatman, and after proceeding for some distance, stopped at last at one of the shops near the seaward end of the street. Here with the aid of Sannio, Caius selected three tunics of light woolen stuff and a like number of togas of similar material, white with scarlet borders. Shoes and headdress to match were bought, all paid for, and the two set out on their return to the inn.

Just as they reached the landing, they saw Lanius and a number of the other young Romans to whom Sannio had referred as upstarts, in the crowd. As Caius had had no occasion to come in contact with Lanius since their meeting at Spoletum, he had consequently not been again insulted. But now, Lanius, with his air of haughty insolence, called out so his companions could hear, "See, here is our shepherd who wanted to be a soldier. I wager that we shall see him in fine feathers to-morrow."

"Heed him not," whispered Sannio in Caius's ear. 
"A brawl with him and his companions can be of no help to you. Let us pass this way to the right and on to the tavern." And so they stepped out of the boat

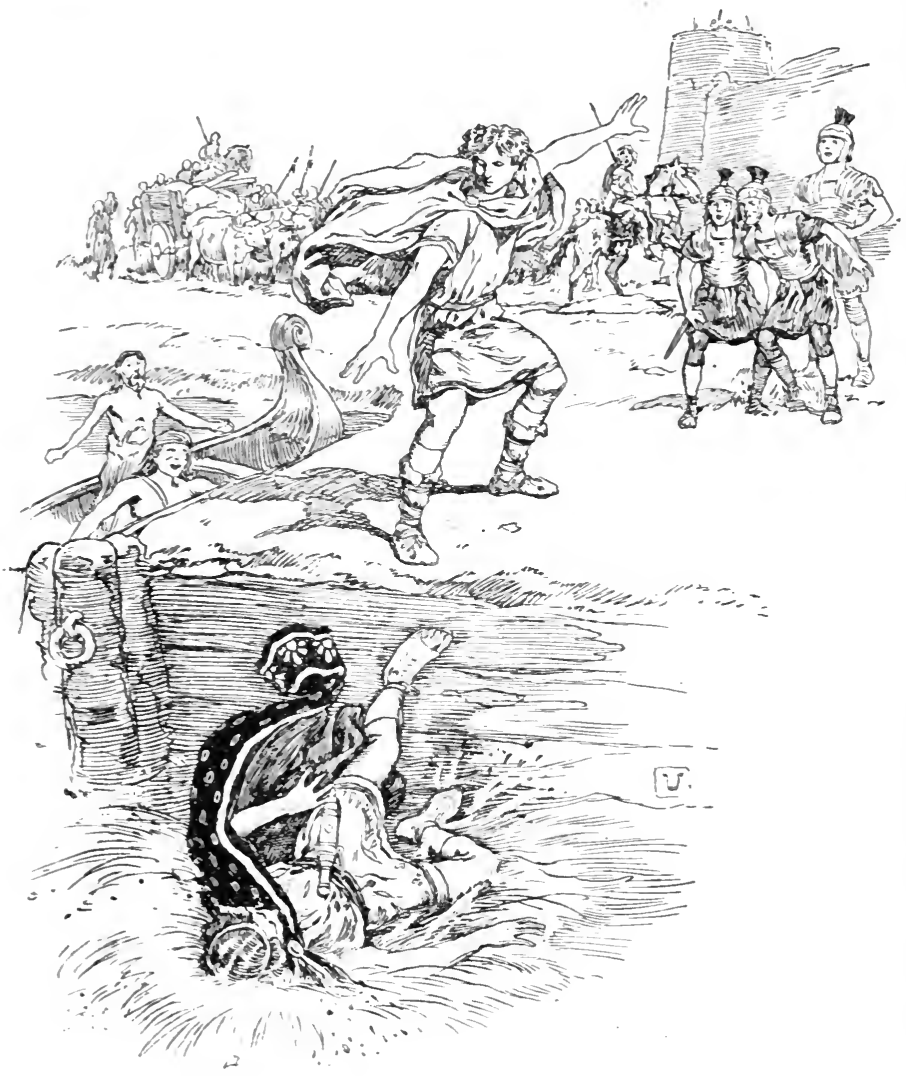

and were just turning away, when Lanius thrust himself before them.

"So our young soldier will not speak to me. You have grown a great pride in a short time. Because of 
weightier matters, have you forgotten your sheep and goats?"

"No;" replied Caius, "and with apologies to all other goats, it seems I am not to be allowed to forget a certain goat."

"What do you mean?" shouted Lanius, now enraged. "I will teach you." And he struck at the face of Caius with his hand, but Caius evaded the blow, and profiting by what instruction he had received from old Simmias and his practice with Titus, he quickly tripped Lanius, who stumbled forward headlong, trying to keep his footing, and thus carried himself face first into the muddy water. A burst of laughter and applause arose on all sides. But Caius was already dragging Lanius from the water, who had risen after having at once sunk like a stone. The latter had no sooner regained his feet than, dripping, bubbling, and sputtering, he drew sword, and was rushing at Caius, when a large man who had been standing near, grasped the sword arm of the enraged Roman, and stopped him short. "Hold!" he said quietly. "You had best think a moment. The other has just dragged you from the water, and now would you stab him?"

"Yes, the plebeian upstart that he is!" shouted Lanius. "Let me loose, or it will be the worse for you."

"Not yet," said the stranger, coolly. "Don't be in such haste. He might give you another souse in the water."

"Sextius Baculus, by Hercules!" now cried Sannio, who had quickly stepped between Caius and Lanius; and addressing the big man who still held the wrist of Lanius, he asked, "Where did you come from?" 
But there was no time for answers now; for in the crowd which was pressing about, the form of the lieutenant, Quintus Pedius, appeared, accompanied by three or four legionary soldiers.

"What is the trouble here, Sannio ?" he asked calmly.

"This boorish upstart has insulted me," threw in Lanius, not waiting to be questioned.

"I think he did," laughed a bystander. "He gave you a ducking in the Adriatic."

"Speak when called upon, Lanius," commanded Pedius. "Sannio, give me an account of this matter."

This Sannio briefly did. "And I as an old comrade of Sannio and a soldier under Julius Cæsar, know that Sannio has spoken the truth about the matter," added the man who had been called Baculus.

"Now what have you to say for yourself?" asked Pedius, turning to Lanius.

When the latter could not bring forward a single statement to his advantage, Pedius said, "Lanius, since we left Rome, I have warned you more than once that you would get into trouble. Here I have orders from Cæsar to take especial care of this youth. You would have small favor from Cæsar should word of this affair come to his ears. If I hear of any more of it, I shall report it to him, and then your hope of military service in Gaul will vanish. Sannio, return with the youth to your quarters."

Then as Caius and Sannio pushed their way through the crowd, accompanied by Baculus, Caius found himself wondering why Cæsar had bought clothes for him and why he had given especial orders concerning him. But his mind was not permitted to dwell long on these 
questions, for his attention was strongly drawn to Baculus, whom he now observed closely. Meanwhile, the latter and Sannio, as old comrades in arms are wont to do, asked and answered questions as to where they had been, what they were doing and were going to do.

Baculus was tall, thick-set, well-formed, and straight as a staff. He was fair, and had steely blue eyes set in a hard but honest face. His straight carriage, steady tread, and scarred face and hands showed him to be a real soldier - one who had been in the thick of battle, where he had taken as well as given cuts and thrusts.

"And who is this stout youth whom Cæsar wishes well cared for, Sannio, and yet leaves to so funny and reckless a fellow as you are?" asked 'Baculus as they reached the tavern.

"Why should I not care for him as well as any big fellow who looks more fierce and feels more gentle than I do ?" retorted Sannio. "But as you seem anxious to know, so far as I can see, there can be no harm in telling you. He is Caius Volcatius Tullus. He goes with Pedius to Gaul at Cæsar's request."

"I am right glad to know you, Caius," said Baculus. "You gave the boaster a good ducking, and I hope it will help his manners. You are very fortunate, too, if you have come into Cæsar's favor. He is a great man and going to be greater."

"I am glad to know you, Baculus, for you look a good soldier, and that is what I mean to be," said Caius, simply.

"Well, here we are at our inn, and I am hungry," said Sannio. "My jaws have had a long vacation 
and my teeth are dull for lack of use. Come, let's eat." And then they pushed their way among the soldiers and merchants that thronged the inn and sat on low stools about a three-legged table, and ate heartily of the bread, meat, and cheap wine which the host placed before them.

"But let me tell you, Caius," went on Baculus as he drained his horn cup, "you are likely to march long and late, wake soon, and fight hard, if you serve under Julius Cæsar. You remember, Sannio, year before last, don't you, in Spain, when a tribe of those Iberians were making trouble and had collected a band fifty thousand strong? Well, when Cæsar was informed, he at once called his soldiers together and made a speech to them. And such a speech! It wasn't long and it wasn't loud, but when he finished, the soldiers' shouts rolled along the hills and valleys till you'd have thought there were ten men instead of one of us. And every man of them was ready to march on a solid line of Spanish spears for Cæsar. Then on his big horse, long-footed and glossy-coated, he rode up and down the lines, looking over his men, only six thousand in all. 'Baculus,' he said to me, - he knew every soldier by name, Cæsar did, - 'we can rout them, can't we ?' 'Yes,' I shouted, 'with you to lead us.' '

"Sure, I remember," broke in Sannio. "He knew me, too, and asked me if I didn't think it would be fun to see them run. I remember, too, that he reminded us of the glorious deeds of Paris at the siege of Alba Longa and the bravery of Hannibal at the taking of Troy."

"Yes, and Cæsar led us, too," said Baculus, failing to notice Sannio's mixing of history. "We marched 
after him all that night. We came to the barbarians' camp a full hour before day. They were all asleep, thinking Cæsar was twenty-five miles away. We fell on them so suddenly and fiercely that they hadn't time to get their poor weapons. They fled in all directions. We cut and slashed and hacked among them, right and left, till day came and no more could be found, except such likely youths and maidens as we had taken prisoners to sell as slaves."

"But the plunder he gave us!" exclaimed Sannio, smacking his lips over a morsel of meat. "Why, I got enough gold and silver ornaments to buy my old mother a little farm close by the Tiber, where the finest nuts, grapes, and olives grow."

"And I got enough to keep myself living in plenty from that day to this," laughed Baculus, "and besides, three handsome boys that I sold at Rome. Yes, Cæsar's men must march and fight, but he knows them and honors them and gives them plunder. And they never fail him."

"I am told that Cæsar himself had some plunder in Spain," said an old man who had been sitting at a nearby table, sipping his wine and listening. The others now turned and saw a small, droop-shouldered, man, with a leathery, wrinkled face, and, under heavy lashes, a pair of glittering black eyes that seemed to be always searching for something they never found.

"You are told wrongly," said Baculus, with warmth. "Cæsar only collected taxes, as is allowed to Roman governors in the provinces. If the tax was rich, so much the better for Cæsar. And if he gave over a few thousand rebellious savages to be plundered by his 
good soldiers who restored the peace of the province, who is to say that Cæsar himself plundered ?"

"Come, come," said the old man. "I meant no harm."

"If Cæsar collected great tax, he paid a worthy debt, one made by himself for the Roman people," said Sannio. "The games he provided while ædile of the City have never been surpassed."

"There you are right," exclaimed Baculus. "I have seen games for a whole week and enough gladiators to furnish over three hundred separate fights. As many gladiators, bears, lions, and the like were slain as would last the vultures on the Esquiline Hill for a month. And the people - why, they worshiped him. He could hardly appear on the streets without a crowd trooping at his heels eager to do his slightest wish."

"I see you think Cæsar a very great man, but I believe he will not take much money away from Gaul," said the old man.

"No one believes the hare-brained, hot-headed, fighting, quarreling Gauls have much money," said Sannio. "They are too busy making trouble to make much money or other wealth. Brave as mad bulls, but poor as the priests of a new god."

Baculus laughed and Caius smiled.

"In that you are mistaken, my friend," returned the old man. "I am Marcus Pomponius Matho. My father's grandfather was a merchant and trader before me. He was made a prætor when the Romans warred with Hannibal. He was once sent by the state with a golden crown of two hundredweight to consult the oracle of Delphi. I have his name and I am proud 
of it. I also am a merchant, and have traveled in all parts of Gaul, so I ought to know what I speak of. The Gauls have many walled cities, rich and prosperous. Why, Bibracte, the capital of the Hæduans, would be a surprise to any one who thinks them unskilled barbarians. The Gauls are good farmers and fertilize their soil with marl. They raise the best horses, the largest cows, the finest oxen, and hogs without number. They make the best cheese, and every year thousands of cartloads of dried bacon are sent out of Gaul. They weave strong cloth and dye it in beautiful colors. They dig gold, iron, and copper from the mines, and have more skill in tempering brass than any other people in the world. They mint money after the Greek style and carry on some commerce though not very much, since they have about all they need at home, and do not want to learn the bad customs of other nations. But let me tell you," the old man went on, "the Gauls mean to keep what they have. If Cæsar should trouble them, good general though he be, he will find a task not like that among the Spaniards. Cæsar would do well to pray the gods not to put it into the heads of the Gauls to attack Rome again. The Gauls are fighters. Their religion teaches them that they will live again in a happier world, and so they do not fear to die. Why, don't you know that they swarmed into Italy and burned Rome itself over three hundred years ago? Don't you know they have broken over the Alps time and again and have kept the Roman people under dread of them most of the time since? Don't you remember that the Gauls were among the most stanch of Hannibal's allies? My father's 
grandfather told him so, and he told me. Don't you know that a great weight of gold is yet kept in the treasury at Rome to buy them off should they ever appear before the walls again?" The old man stopped and looked over the group that had gathered about him with the air of one who had convinced all hearers. He was a Roman himself, but knowing something of the history of the Gauls, and having been much among them, he was not sure that they would be so easily subdued by Roman arms.

Caius began to think that perhaps he was going into a very unsafe country - one where a soldier's fame might not be so easily and quickly won as he had fancied. "But Rome has grown great in three hundred years," urged Baculus, with energy, "and besides, the Gauls have never met Julius Cæsar in battle.”

"I think they may not wish to meet him after the first time, either," laughed Sannio.

"Why should it be thought certain that there is going to be war with the Gauls because Cæsar is proconsul to Cisalpine Gaul ?" asked Caius. "Is not that province entirely separate from Gaul beyond the Alps ?"

"To be sure it is," replied the old merchant, quickly. "But Rome and Roman governors always find excuse to meddle in the affairs of the peoples adjoining Roman provinces, and conquer them sooner or later. From all you say of Julius Cæsar, I have no doubt that there will soon be war with the Gauls. It is reported that even now the Helvetians, a Gallic tribe, are planning a move that will bring a clash with Rome."

"The sooner it comes, the better it will suit me and all the other soldiers of Cæsar," said Sannio. "I 
hope it will come on and not take a backward turn like a calf's tail."

"Yes, and I'll soon be found under Cæsar's eagles again, I think," said Baculus. "I am tired of this easy quiet way of life. The bolder and fiercer the Gauls, the freer the fight and the richer the plunder."

Caius, remembering all the evil he had heard of the Gauls, and knowing all his family had suffered from them, could only hope there would be a war, and that a very destructive one to the Gauls. He was eager and ready to do his part in converting all Gaul into a single Roman' province. He had realized his hatred of the Gauls, and his desire for revenge formed his leading motive in life just now.

Baculus, watching the face of Caius, seemed to understand what was passing in his mind. "It will soon come, friend Caius," he said. "You will be a soldier, and I hope you and I may see fighting under the same eagle. Perhaps Cæsar will enroll new legions and put us both in the same one."

"I could wish nothing better," returned Caius, for he had come to admire the kindly strength and wholesome heartiness of big old Baculus.

"Well, it is late, Caius, and we must stir early," said Sannio. "Let us to sleep."

"Then, farewell, Sannio, and my young friend, Caius," said Baculus. "If Cæsar makes war in Gaul and raises new legions, you will see old Baculus again before long." And he strode away, snapping his big fingers and whistling a merry tune. 


\section{CHAPTER V}

\section{THE SHEPHERD BECOMES A LEGIONARY}

THE fertile plains of the Po passed, the party of Pedius, moving northward, began to ascend a higher region, and to wind over gentle slopes and through little valleys - all covered with grass, dotted with flocks, and comfortable with the humble homes of farmers and shepherds. Then, far away, over the green grasslands, beyond the smaller hills, beyond the larger hills thick grown with trees, Caius felt himself awed at the sight of the snowcapped Alps, rising upward, upward, and losing their whitened peaks in the misty grayness of the upper sky.

Although it was spring, the passage over the snows of the Alps was cold, but without mishap, and about dark of the sixth day after leaving Ravenna, the party arrived at Geneva, where Cæsar himself was posted. This was a considerable town of the Allobrogians, at the southern end of Lake Geneva.

Just on the outskirts of the place, Cæsar was encamped with a single legion, the one called the Tenth. Pedius led his party directly to this camp, and at once reported to Cæsar in his tent.

In a short time a messenger came to Caius where he was waiting, and said, "The Proconsul Cæsar desires Caius Volcatius Tullus to come to his tent without delay.'

The youth obeyed and went to a large leathern tent, 
from the top of which floated a white flag, the mark of the general's quarters. When he had entered he observed that the floor was covered with beautiful tiles; for in Cæsar's baggage always went these tiles for flooring his tent.

"Well, Caius, I see that your mother was willing for you to come with me to Gaul," quietly said Cæsar, upon the entrance of Caius.

"Sir, she was glad for me to come with the noble Julius. I think I now know why I was honored with the invitation to come, and I am sure I know why my mother gladly consented," said Caius.

"I asked you to come, Caius, chiefly because I thought I saw in you a good soldier and a true man," returned Cæsar, rather firmly. "There might be other reasons, too, but let us get to business and not say too much about that at present. Now that you are here, would you choose to do real service as a soldier, with a prospect of promotion if worthy, or do you prefer to be one of the hangers-on about the camp, depending upon the favors of Fortune to raise you to place and wealth ?"

"With your leave, sir, I should choose to serve in the ranks till I can learn to be a real soldier, and then I may be able to show myself worthy."

"Your decision is good," said Cæsar. "I shall raise new legions and place you in one of them. In the meantime, you may be a tent fellow with Sannio, and report with him for service to-morrow. I shall keep you in mind, and I expect you to show yourself a man and a soldier. Come and consult with me should you find it necessary." And then he dismissed Caius and turned to other affairs. 
As the youth left the tent, he met near the door a number of the gayer young men in brazen armor, who had come in the party under Pedius. Among them strutted Lanius. He looked at Caius with wonder, and almost stopped short before him in his surprise; but Caius gave no heed, and hurried on. However, he was not rapid enough to miss hearing one of them say, "Lanius, your young shepherd seems more in favor with Cæsar than we are."

Caius slept soundly that night in a leather army tent, with Sannio and seven or eight others - the usual number assigned to a tent in the Roman army at that time. At daybreak, he was awakened by the hoarse blare of a bugle.

"Ah," cried Sannio, jumping up. "That seems like old times in Spain. We must now get something to eat and be ready for the next thing - no one knows what that will be where Cæsar commands."

When Caius looked forth from the tent he saw the camp alive with soldiers clad only in their tunics and shoes, all hurrying in one direction. At the same moment, one of his own tent mates brushed out past him with a basket of grain on his shoulder. To Caius's look of wonder, Sannio explained, "They are going to the quæstorium where the hand mills are kept to grind the barley so it can be made into bread or broth. The men who tent together take turns at grinding the grain."

After Caius had washed down with cold water the simple and slight meal thus referred to, he heard the notes of the bugle again peal forth.

"That means," said Sannio, "that we are to assemble 
at once in the prætorium. "Casar doubtless has something of importance to say." And together they hurried out to be quickly mingled with hundreds of soldiers wearing their arms and armor, all pushing toward a large open square near the end of the camp. They found Cæsar already mounted upon his earthen tribunal.

The soldiers had collected in an incredibly short time, and before Caius hardly realized it, quiet had ensued, and Cæsar was speaking: "Fellow soldiers, the Helvetians, one of the most powerful and warlike peoples of all Gaul, are now threatening to march in a body through our province. They are planning to leave their own somewhat narrow territories and take up their abode in a new region. Should they do this, it would not only be a danger to the safety of the province, but also an insult to the dignity of Cæsar, yourselves, and the whole Roman people. To prevent this I propose to make a wall and ditch from Lake Geneva to Mt. Jura, a distance of nineteen miles.

"As to the Gauls themselves, we need not dread them; for the Romans have overcome them in numerous battles for the last two hundred years. True, they attack with fierce yells, a dreadful rattle and clangor of their arms, and incredible speed and bravery. But if stoutly and steadily withstood, they soon give way and fly. Gallic rage can never stand against Roman valor.

"I know of your courage and fortitude, especially that of the Tenth legion. I am sure it is not necessary to make an appeal to you on this occasion. I know that I can depend upon you. Let us build these 
works as rapidly as possible while our other men collect. I think we shall soon have more lively and mayhaps more profitable tasks. Let us do our duty, and our rewards will come."

This short speech was delivered with such energy of manner and such magnetism of gesture and expression, and especially were the last two sentences uttered with such insinuating grace, that Cæsar was greeted with shouts and cheers. He quickly silenced this applause by a motion of the hand and at once began giving orders to his officers, who had gathered around him.

Trumpets sounded, and immediately all were in motion. In a few moments, Caius saw thousands of soldiers marching out of camp, with picks, shovels, axes, and dirt baskets to build the wall and ditch.

While watching these depart, Caius was approached by Lanius, who was making an effort to smile pleasantly. "I did not know that you were under the especial care of Cæsar, my friend," he said. "I hope you will pardon my little jokes and be friends with me. I assure you I meant no harm."

"I fail to see why your ignorance of Cæsar's small but kindly interest in me should have anything to do .with the unprovoked insults you have offered me," replied Caius, rather coldly. "But as to being friends, I can say that I shall make no effort to do you harm." "I am a free man among free men," flashed Lanius. "I owe no man and I shame to face no man. I own three villas and much money. I feed fifty crops, six dogs, and a couple of horses. I drink the best wine, and always find myself welcome among the ladies." 
"I care nothing for your wealth," said Caius. "But we can be friends if you show yourself really friendly."

Lanius, though eager to repair what seemed a mistake, could hardly bear the cool and determined manner with which Caius met his advances. So he said with an effort at control of himself, "Very well, I shall see what I can do," - an answer which might have a double meaning - and he turned away.

"Did you see the look of hate and revenge on his face, Caius?" said Sannio, who just then came up. "You have made an enemyif not a strong one, at least a sly one. I knew his father. He was a butcher, and one of the worst men in Rome. You had best be on your guard against the young one."

Immediately another trumpet sounded in the camp, and Caius with a number of other men hastened into the wide, open space between the tents and the camp wall, for military drill. Under officers detailed for the purpose, the youths were put through exercises for strengthening the arms, wrists, legs, and whole body. After several hours

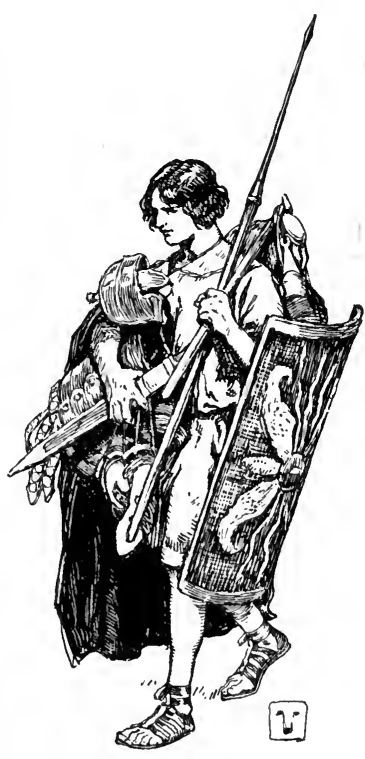
of this work, they were marshaled to the quarters of the camp prætor, where that officer provided each with a quantity of unground barley - rations for two weeks and a soldier's outfit, consisting of a short sword, a 
long javelin, a leather-covered, iron-bound shield, an iron helmet, and a metal-plated, leather coat of mail.

Caius found that for the time being he had been placed as a tent fellow with several former soldiers of Cæsar, and with others, for various reasons, in Cæsar's favor. One of these latter especially attracted the attention of Caius that night after all had collected in their tent and were chaffing and joking each other. This person - Procillus, the others called him - was of massive form, tall, broad in the shoulders, down to which hung the thick, fair, curling hair of a great head. He had a big yellow mustache, blue eyes, high cheeks, and fair complexion. He wore the clothing and arms of a Roman soldier, but, besides, he wore vari-colored trousers, and rings, bracelets, and armlets of gold, more massive and barbaric than was usual among the Romans.

"Will these Helvetians who are now threatening a march through the Roman province fight Cæsar, think you, Procillus ?" asked Sannio.

"Yes, they will fight Cæsar or any one else. The Romans should know that well, since one of their armies under the consul, Lucius Cassius, was some years ago defeated, and the consul himself slain," replied Procillus in a voice harsh, heavy, and Gallic in accent.

"But they are likely to find a different task when they meet Cæsar, are they not?" asked another.

"Yes, I think so," answered Procillus. "Cæsar is a great man and a great soldier. For my part, though my father was born a Gaul and I am still a Gaul at heart, I sincerely wish my people would learn the cul- 
ture and humanity of the Romans. I am sure our Gallic land and people could be much improved. Our armies would be almost invincible if well drilled and organized as is the Roman army. But the Gauls lack patience.

"You have noticed the three young Gauls who stand for hours each day in the prætorium, wearing only a short straight tunic. Well, they enrolled in Cæsar's army, thinking there would be nothing but to fight, as is usually the case in the Gallic army. But when they found that they must drill, drill, day after day, Gallic impatience and stubbornness made them rebel, and so they stand at their meals, are deprived of their pay, wear the straight tunic, and stand in the hot sun like any insubordinate Roman soldier."

"But Cæsar is kind to them," interrupted Sannio. "He stops and speaks to them. By and by they will love him, and be ready to lay down their lives for him."

"Yes, that is Gallic nature," went on Procillus. "His kindness will lead them, but they will not be driven. Also, when I asked Cæsar many questions about Rome and its people and their customs, he told me that the Romans have schools in which their youths learn many useful things. The Druids keep our only schools and they teach but of our religion. Cæsar told me that the Romans have hundreds of straight, stone-paved roads to all parts of Italy. Our roads are only open streaks winding through the forests like a broken serpent. They are often boggy and impassable. Our agriculture and commerce could be greatly improved. Then, too, Cæsar told me that all Italy is united in one strong government. That is not the 
case with us Gauls. We are divided into scores of different nations. We love to quarrel among ourselves, to differ in every way possible. We will never unite. Each nation is divided against itself, and there is scarcely a family but its members take sides against each other in all public affairs."

"Do you think it probable that the Gauls will ever willingly accept Roman civilization?" asked Sannio.

"No," said Procillus. "They are proud, brave, and believe themselves invincible. Besides, they think they are already superior to the Romans in culture as well as in courage.'

During the succeeding weeks, Caius drilled many hours each day, developing strength, learning the use of his short sword, hurling the long heavy javelin, and becoming accustomed to his armor. Then, too, there was the carrying of heavy weights, practice in vaulting upon wooden horses, and attacking a wooden man as though he were a real enemy. Indeed, Caius began to be quite a soldier in his helmet, tunic, and metalplated coat of mail.

Occasionally, he saw Lanius, who had chosen to try his chance for promotion without the trouble of service in the ranks. The latter was always dressed in the daintiest style that camp life would permit. He still made efforts to appear friendly to Caius, who fully distrusted him, because of the thoroughly graceless manner in which he did it.

Meanwhile, Cæsar, leaving the camp and fortifications under the command of Titus Labienus, his most trusted lieutenant, himself had hurried into Italy to 
enroll new legions. He soon returned, bringing three old legions and most of the men for forming two new ones.

Caius was at his drill when these troops came marching into camp. When he had finished and returned to his tent, whom should he meet there but his old friend Baculus.

"Well, Caius, I am glad to see you again," shouted Baculus, very heartily. "I told you that we should meet again, and here I am. What a fine-looking soldier you are! You promise well."

"I am truly glad you have come, Baculus," said Caius. "I am sure you can teach me much, and I am eager to learn the art of war."

"Well, I have no doubt you will do that," returned Baculus. "In what legion are you enrolled?"

"I do not know yet," replied Caius.

"We will get Pedius to mention the matter to Cæsar. I think you and I can be placed in the same one. I am to be in the Twelfth," said Baculus.

"That will indeed be to my liking," said Caius.

Following this plan, it was arranged the next day for Caius and Sannio as well as Baculus to become members of the new Twelfth legion. Baculus was given position as the first centurion of the legion, and Sannio was made centurion in the second hundred of maniples. As most of the men of the legion were fresh, Caius was placed as a common soldier in the second hundred. In these positions, the three friends were near each other in the ranks.

A day or two later, to his great surprise, Caius got a glimpse of old Eredox among the merchants and camp 
64 THE STANDARD BEARER

followers. "How came he in Gaul?" wondered Caius. "I left him at Spoletum, I thought. Besides, I wonder how many enemies I shall have among my friends. Here are Eredox and Lanius - both sly fellows to be watched." 


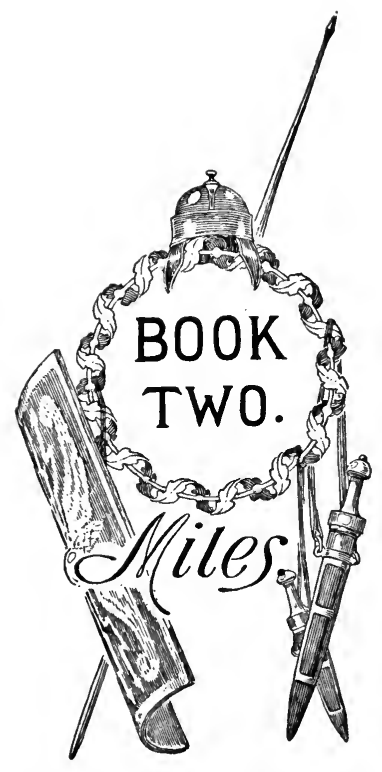




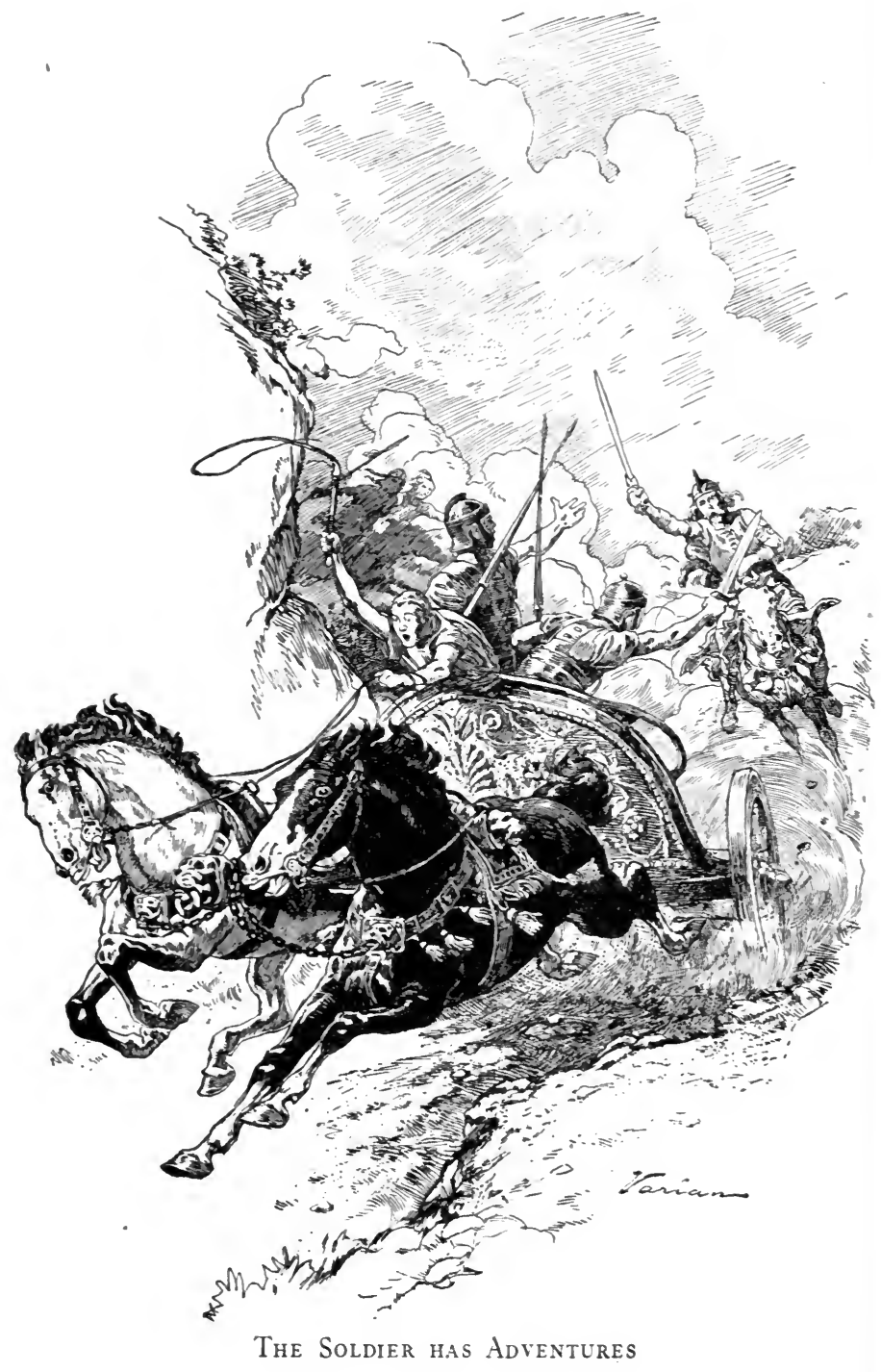




\section{CHAPTER I}

\section{THE SOLDIER HAS ADVENTURES}

Nearly two months had passed since the Proconsul entered Gaul. It was now June, and the sun was daily running higher up the horizon and shedding bright floods of heat over the earth.

On one of these days, Caius saw five Gauls, seemingly of high rank, come into the camp. They appeared to be in great haste, and their faces showed excitement, and even despair. Caius noted that they were received at Cæsar's tent, and he saw them depart later in the day, seemingly more hopeful. The next day and the next, these Gauls and others came to the camp for conference with Cæsar. There was a rumor among the legionaries that the Hæduan Gauls feared the Helvetians, who were now attempting to pass into Gaul by a route other than the one which Cæsar's fortifications had blocked against them. Several days later, one morning at early dawn, the slumber of the soldiers was broken by the hoarse blare of the tubas sounding the signal to strike their tents, pack their baggage, and be ready to march at sunrise.

As soon, as their slight morning meal was eaten, Sannio showed Caius how to pack into a compact bundle his surplus clothing, his heavy soldier's blanket, an ax, an iron hook, a leathern thong, a chain, and three or four wooden stakes. This bundle was to be fastened on a wooden staff and carried on the shoulder. 
The soldiers jokingly called it the "mule of Marius." These articles Caius, as well as every other Roman soldier on the march, must carry in addition to his helmet, shield, sword, and javelin.

When Caius turned to look about him after finishing this task, he was surprised to see that the tents were down and loaded on pack animals, along with the hand mills, prætor's stores, and other heavy articles of the camp. Indeed, some of the older legions were already forming for the march. Everywhere was noise - the blare of the trumpets, the shouts of men, the neighing of horses, the loud braying of mules, the clangor of arms, and the jangle of harness.

But out of all this seeming confusion, order soon appeared, and the legions began to move. As the Twelfth had been ordered to bring up the rear of the army, and was consequently stationed to wait till all the others had passed forth from the gate, Caius had ample opportunity to see the legions in motion.

First, after the scouts and a small advance guard of light-armed skirmishers, came the Tenth legion with its fluttering standards of scarlet and its golden eagle. The men of this legion won Caius's greatest admiration, for they showed by their firm tread and strong faces that they were soldiers of skill and experience. Each carried his bundle, but their heavy baggage followed them, loaded on pack horses, mules, and wagons. Next came another legion followed by its baggage, and then another and another, till five had passed the camp gate.

Then the Twelfth fell into place, and now Caius could see that the head of the long, swaying, waving 
line, moving twelve by twelve, had disappeared into the forest, a mile away. He thought he had never seen so fine a sight as those thousands of sturdy, steel and bronze clad men, whose arms and ornaments flashed and sparkled in the sunlight of that bright June morning not less than the millions of dewdrops on shrub and tree.

He was filled with eager delight, and a pride such as he had never known thrilled him as he felt himself at last, in fact, on the march, a real soldier. The blood of his Roman fathers was astir, his heart beat high, he stepped proudly.

"Take it easy, Caius," said Baculus, who dropped back near him for a moment. "Take it easy and step light. Before we camp, the road will be extra hard and the bundle double heavy."

"I'll try to do as you say, Baculus," said Caius, somewhat taken aback, "but it's hard to take it easy now. I feel a swelling of the heart, a something I can't say."

"You'll feel a bigger something-you-can't-say than that after awhile," laughed Sannio. "You'll feel like you are going to drop under your load, and still you'll be compelled to march on and on."

"Why, Sannio, is it so bad as that?" asked Caius, in grieved tones.

"Never mind, never mind. You'll get used to it so you can carry twice as much," said Baculus, who now returned forward to his place.

The whole army moved rapidly westward. No one seemed to know exactly where it was going, but there was a general impression that the Helvetians were to be met. Visions of rich booty to be won were already 
delighting the imaginations of Baculus and Sannio, as well as hundreds of others of the older soldiers.

When the sun was almost straight overhead, far down a broad opening in the dense forest there was seen rapidly advancing a great body of horsemen. The Romans were halted and stood awaiting the approach of the others.

"They mean no harm," said Sannio. "There can't be more than three thousand of them, and even the fighting Gauls are not so mad as to attack five legions with so small a force."

Procillus, who acted as a sort of attendant and interpreter for Cæsar, now came riding back from the front to give Baculus some order.

"Who are they, Procillus?" shouted the centurion.

"Only a body of cavalry which the Hæduans have sent to Cæsar to aid in driving the Helvetians out of the Hæduan country," answered Procillus. He gave Baculus his message and at once returned to Cæsar.

The body of horsemen was now near enough to be easily seen. The men were mounted on rather small but strong, wiry horses. Each man was clad in trousers, a shirt, a tunic of bright and varied colors, a brazen coat of mail, and a brazen helmet adorned, some with tufted horsetails, others with the horns of animals, and still others with the wings of eagles. Most of them also wore heavy bracelets, armlets, and collars of bronze and gold. Almost every man of them had the skull of an enemy hung to his horse's mane.

Their leader, Dumnorix, a proud and ambitious young noble, was of the same general appearance as the rest. To the mind of Caius, the great face of this 
man, with its stern eyes, big, fierce mustache, and set jaws, seemed to express, more than all things else, defiance.

"And has this man come to aid Cæsar?" he asked. "I would more readily believe that he had come to spy upon him and to play him some trick of treachery. Cæsar would do well to watch him."

"Never fear," took up Sannio, good-humoredly. "Cæsar watches all men who serve him. But they never know it, and always feel that he trusts them fully."

After some passing of messengers and a conference between Cæsar and Dumnorix, the Gallic cavalry joined with the army, and all were again soon in motion.

Caius now began to feel the truth of the warning Baculus had given him in the early morning. His baggage weighed, in fact, about fifty pounds, but it seemed now to have grown to a weight of at least a thousand. He felt that he would fall and be crushed under it in spite of all he could do. Several of the weaker men had already fallen and had been placed upon the wagons and pack animals.

But Caius held stubbornly on, and about two o'clock the trumpets sounded, sharp commands ran along the lines, and a halt was made. The army had reached the place where a camp had been laid out by the officers and the men sent ahead for the purpose. This place was on open ground sloping gently downward in the direction in which the army was moving. At the foot of this slope, near the camp, a small stream of clear water flowed, where men and animals were already slaking their thirst when the Twelfth legion came to a halt. 
Immediately all were set to work to build the camp. Some retaining their arms and armor stood guard, others put up the tents, some dug the ditch with pick and spade, while yet others carried the earth from the ditch in baskets to build the wall. This task required steady work for three or four hours.

Caius was helping to bring timbers to build a wooden rampart on the top of the earthen wall. As he and a fellow worker were carrying a long pole past where a group of peddlers and camp followers were erecting some rude tents outside the camp, he was surprised to see Lanius and Eredox in close and earnest talk. The two did not notice Caius at first, and he had passed near enough to them to overhear his own name spoken by Lanius, before they observed him. They immediately separated, each seeming to make an effort to lose himself in the crowd as quickly as possible.

Here was a new puzzle for the youth. "How did these two come to know each other?" and the wonder grew and grew upon him. Wearied as he was by his first day of actual marching, he lay sleepless late into the night, thinking, wondering about the thing. At last he got up, went outside, and sat on a stone near the tent, in the bright moonlight. It was cooler there, and gradually his vexation began to subside. "It was only by chance that they spoke together, and perhaps it was not my name, after all, that I heard," he thought. "There are hundreds of soldiers in the army named Caius. Besides, I believe that Eredox has had enough of me, and perhaps Lanius fears Cæsar so much that he will not trouble me."

But just then he heard a rush and a curse in the tent, 
and almost at the same time, a man dashed out of the tent swiftly followed by Baculus, who made a savage cut at the fugitive just as he passed Caius. The latter had sprung up only in time to recognize Eredox as he disappeared, dodging among the tents.

"By Hercules," muttered Baculus. "I wish I had struck the villain. What could he be doing, sneaking into our tent? and who is he, anyway?"

"It was Eredox, an old Gallic soldier from Spoletum," said Caius. "Where did he come from just now ?"

"Perpol! I don't know," replied Baculus. "The first I knew, he had tripped in my blanket and fallen headlong in the tent. I seized my sword and followed, and you know the rest."

Then Caius told Baculus in low tones what he knew of Eredox, but did not deem it wise to tell of seeing him with Lanius. He feared it would not be well to implicate Lanius in a questionable relation without direct proof.

They went back into the tent. Sannio and Procillus were sleeping soundly. When Caius had left the tent to go outside, he had also left his heavy soldier's blanket lying in a heap. He now stooped to pick it up. To his wonder it pulled and slipped from his hand. On close examination he found that a sword had been driven through the several folds of it, and on deep into the ground, where it yet remained.

"He was trying to kill you!" exclaimed Baculus. "You must be on your guard."

"Yes," replied Caius, simply. He was now sure he understood what he had seen in the afternoon. But as there was little to be said and less to be done, he 
lay down. As nothing more was seen of Eredox in the camp, Caius decided that he had gone, and as Lanius made his usual efforts - neither more nor less - to be friendly the next day, the alarm of the youth was soon forgotten in the stirring scenes of the succeeding days.

It now became definitely known that Cæsar was in pursuit of the hordes of Helvetians who, with their flocks driven before them and their women and children huddled in wagons, were descending into Gaul like an avalanche. Indeed, after a few days, Cæsar himself led the Tenth legion out of camp and marched away. Caius learned on their return that the Proconsul had attacked the Tigurini, a part of the Helvetians, on the bank of the river Arar, and cut them to pieces. The elation among the Romans at this victory was somewhat damped a few days later when the cavalry of Cæsar, composed of the Hæduan horsemen under Dumnorix, was defeated by the Helvetians and driven like sheep from the field.

Nevertheless, the pursuit continued day after day. Once Cæsar had almost brought them to bay and forced a battle, but his plans were thwarted by one of his oldest lieutenants, Publius Considius, becoming panicstricken. But when Cæsar's army was almost without food, and he had turned aside to Bibracte, the capital of the Hæduans, to procure supplies, then the Helvetians thought he feared them, and they turned and followed the Romans.

This was just what Cæsar desired. He now drew up the main part of his army in a triple line of battle to await the Helvetian onslaught. Back of this line, on a 
high hill, he arranged his baggage, and to guard it, he placed the Eleventh and Twelfth legions.

Here, upon this steep and grass-covered hill, these two legions of recruits, under the direction of Quintus

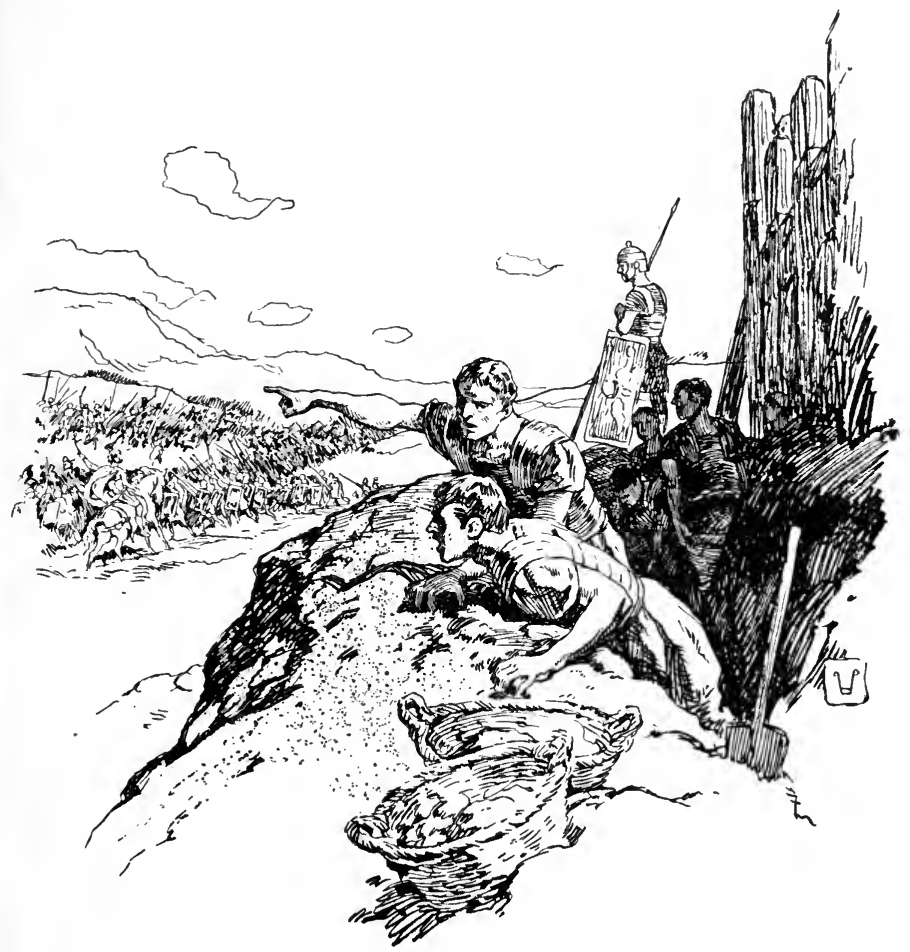

Pedius, hastily drew together the baggage of the whole army, and began making a ditch and wall about it. But even as they feverishly worked, it was impossible for the men to keep their eyes turned away from the teeming thousands of brightly clad Helvetians whose masses were now about to break on the Roman legions. 
Then there was a short pause in the uproar and movement. The silence was intense. Suddenly, with a loud shout and clatter and rattling of their arms, the Helvetians made their attack, driving the Roman auxiliary cavalry under Dumnorix before them. Then they formed their solid phalanx and rolled in an inconceivably close packed wave upon the Roman lines. At this moment, not even the rigidity of Roman discipline could hold the men on the hill to their work of ditching and wall building. Every man of them stood with sight and hearing strained upon the commingling masses of men, horses, shining spears, and glittering swords, weaving and working in the valley below.

“By Hercules!" exclaimed Baculus. "How I wish I were there fighting like a soldier instead of ditching here like a cabbage grower! See, Caius, it is a man's glory to fight like that. In the delight of it, you fear nothing, you feel no cuts, you hear nothing, you care for nothing but victory and the glory and honor of the Roman people. But look yonder! See that body of horsemen running away. Is it not our Gallic cavalry under Dumnorix? Yes, so it is, by all the Roman eagles! And chased by a horde of those striped barbarians. I think you said Dumnorix would bear watching, Caius. By Hercules and all his labors! I wish I were there." And he ground his teeth and clenched his big fists.

But Caius was silent and stood fixed, his heart, like a caged thing, beating against his ribs, his eyes staring on the scene of horror and death below, and a great sickness coming over him.

The carnage continued till late at night, and during 
the whole time no Helvetian was seen to turn his back and flee. But at last when so many of them had been cut down by the Roman swords that they could no longer stand against the steady press of the Roman lines, the survivors broke and fled as if by common consent, and then the Romans cut and hewed them more fearfully than ever.

Those who escaped, after a day or two surrendered themselves to Cæsar. While the hostages and arms of the Helvetians were being collected, six thousand men of the tribe of the Verbigeni, who were among the surrendered, thinking their departure would be unnoticed, just as soon as night fell, betook themselves to flight.

Cæsar at once ordered the Helvetians to bring the Verbigenians back to him if they wished his friendship and protection. The Helvetians searched them out of fen and forest, and dragged them back to Cæsar's camp.

The next morning Caius beheld a horror which he had not imagined possible. At the command of Cæsar, unarmed, the Verbigenians were marched up to a line of legionaries, who stabbed them as they came, until rows and heaps of the huge stripe-clad bodies lay stiff and silent in great pools of their own blood.

And then pity awoke in the heart of the young Roman for his hated enemies, even the Gauls. 


\section{CHAPTER II}

\section{THE SOLDIER HEARS A GENERAL'S SPEECH}

A FEw days later, a great number of chiefs from all Gaul - Sequanians, Parisii, Arvernians, Biturigans, Lingones, Senones, Ambiarrians, Carnutes, Rauracians, and Madubians - great chiefs all, came to congratulate Cæsar on his having defeated the Helvetians, and driven them back into their own mountain homes. Cæsar entertained them lavishly and dismissed them. On the next day, several of them returned and sought a secret conference with Cæsar. It was granted, and for a great part of the day they were shut up with Cæsar in his tent.

"Procillus, tell us about the Gauls who came into camp to-day," exclaimed Sannio after the four friends had gathered that night about a bright light of faggots in their tent. "Were they trying to make peace or shall we look for more lively work to come?"

"I fear it will be what you call lively work," replied Procillus. "The men whom you saw at Cæsar's tent to-day were chiefs. They came from almost all the states of Gaul. As Cæsar had me to act as interpreter for him, I learned their business fairly well. Since I am sure that my tent mates will not strew the news about the whole camp, I can tell you of it."

"Is there likely to be hard fighting?" asked Baculus. "And rich plunder?" added Sannio. 
"Is there to be more trouble with the Gauls?" inquired Caius.

"I will tell you something of the country and its people, and then your questions will all be answered," said Procillus.

"Make haste then," urged Baculus. "I did not get to fight the Helvetians at Bibracte because the Twelfth legion was left to the tame task of guarding the baggage. I am anxious for something to do."

"Well, to begin with," said Procillus, "all Gaul has long been divided against itself. Each state fears the outcome of any united action as likely to be more helpful to its neighbor than to itself. Hence there is continual jealousy and striving. At the present time, the states of Gaul are grouped in two factions. At the head of one of them are the Hæduans; and of the other, the Arvernians. The strife between them has gone on for years.

"At last, a few years ago, the Arvernians hired a body of fifteen thousand Germans to come across the Rhine and aid them against the Hæduans. The Hæduans then had the worst of the fighting, and lost most of their cavalry, nobles, and senators. They were compelled to give hostages to the Arvernians and Germans as a pledge that they would pay tribute and would not seek aid' from the Romans. But affairs were soon worse for the Arvernians than for the Hæduans, because the Germans settled among them and reduced them to the position of allies. And the Germans came in ever greater numbers and still they come, and take the Arvernian lands. Ariovistus, the king of the Germans, is a proud, cruel man, and the Gauls have a 
mortal dread of him and his tortures, whether he be present or absent."

"I imagine these Germans might offer some hard fighting," said Baculus.

"The more the Gauls are divided among themselves, the better for Cæsar and his brave soldiers," exclaimed Sannio. "It is said the Gauls are rich, and if they were not already divided, Cæsar would soon bring about a division."

"Yes," said Procillus. " Divide and rule' might almost be said to be his motto. The embassy which you saw to-day begged Cæsar to aid them against the Germans."

"And did Cæsar agree to do so?" quickly asked Baculus.

"Yes," answered Procillus. "As the Hæduans are allies of the Roman people, he could not afford to do otherwise. Besides, as Cæsar fears the Germans might overrun Gaul and then pass into Italy and even attack Rome, he thinks it best to check them at once. That is why I think we are to have more fighting. Perhaps more than you wish, for the Germans are very fierce and terrible. Ariovistus has an army that has never been beaten, and the men have been so constantly in war and on the march that they have not dwelt in houses for fourteen years."

But in spite of the reputed powers of the Germans, each of the four wrapped himself in his blanket, lay down on the ground, and went off to sleep with no whit of doubt as to the outcome of a battle between the armies of Cæsar and Ariovistus.

Procillus kept the other three informed from day 
to day. Ariovistus had flatly refused a conference with Cæsar, as well as compliance with Cæsar's demands that Ariovistus give up the hostages to the Hæduans and cease troubling these people and their affairs. Ariovistus claimed that Gaul belonged to him and he would act with it as he chose.

As other embassies of Gaul came to complain of the Germans, Cæsar now broke camp, and by forced marches proceeded northward to attack the haughty barbarians. While on the march, a message was brought to Cæsar that Ariovistus was on his way to besiege Vesontio, a Sequanian city, richly supplied with the means of carrying on war. By advancing day and night, Cæsar reached Vesontio, and took possession of it. Ariovistus halted his army miles and miles away. Cæsar spent several days at Vesontio to collect provisions for his army.

On the fourth day after reaching the place, the soldiers were given a day of rest. As Caius walked about the camp, he began to notice that the soldiers stood here and there in groups, talking earnestly and excitedly. On the edge of one of these groups he stopped.

"The Germans are so large," he heard a Hæduan say while measuring as high as he could reach with his arm. "One of them is larger and stronger than four Romans.".

"They may very well be big, but are they brave?" asked Lanius, who happened to be one of the group. Caius easily saw that Lanius was far from feeling so careless as he wished to pretend.

"Brave!" exclaimed the Hæduan. "There are no 
braver people in the world. Their women as well as their men will fight to the death in battle, and you never see a German wounded in the back."

"They are trained to be brave and to fight from their childhood up," added Matho, the old merchant of the Ravenna inn. "I have traveled and traded in the German country," he went on. "I have seen their boys and young men swim and bathe in the icy rivers in midwinter, and they practice going without food for days at a time. I have seen a party of the German young men fix swords thick in the ground, blades pointed upward. Then they would fasten swords and spears in a framework of poles so that some pointed downward over those fixed in the ground, while others extended in all directions over those pointed upward. This made a very bramble of bristling points. Then the young men would leap into the midst of these and dance and writhe and whirl, in and out, up and down, around and about, and never be so much as scratched."

"Why, at the battle of Magetobriga," said the Hæduan who had first spoken, "when we fought this same Ariovistus and his soldiers, I saw Germans leaping and fighting and dodging in the battle in the same way that you mention and at the same time cutting and thrusting with their heavy swords so that there was no escaping them. Both my brother and I, with sword and spear, set upon a big German warrior and made our heaviest cuts upon him, and it is likely that the demon would have hewed us both down had not the whole army taken flight, and so I escaped, but my brother fell, split from head to waist."

Caius saw the face of Lanius grow pale and his lips 
tremble. A sort of uneasiness seemed to have laid hold upon most of the others of the group, and this evidently added to the fear of Lanius.

"But Cæsar is likely to make peace with these Germans, is he not?" asked he. "I am sure I hope he will, for I am a free man among free men. I owe no man and I shame to face no man. I own three villas and much money.r. I feed fifty stomachs, six dogs, and a couple of horses at my own house in Rome. I drink the best wine and always find myself welcome among the ladies. But when it comes to fighting these Germans, I care - " and he broke off with the words stuck in his throat, and turned hastily away to his tent, like a whipped cur.

"No one knows whether he and Cæsar will make peace," said the Hæduan. "I know I shall not meet them in battle if I can get away. I could never bear their gnashing teeth and glittering eyes. Why, in the battle of Magetobriga, you could see the fire flash and sparkle from their eyes. It burned your face and you could not bear to look upon them. When fighting, they roar and rage and rally like so many wild boars." The Hæduan's face plainly showed that he was in earnest and that he had experienced the terror that he was inspiring in his listeners.

The group soon began to fall apart. Caius moved toward Cæsar's tent, where he had been appointed to stand guard during the evening. The old merchant, Matho, fell in by his side and tried to sell him a strong coat of chain mail of superior workmanship. "You will need it much when Cæsar leads you into battle with the Germans," he argued. But Caius, well know- 
ing his mother's need for all the money he could earn, thanked the old man, left him, and hurried on up the streets between the tents to his duty. On the faces of all he met, he now saw fear and doubt. Dread seemed to have settled on every soldier in the camp. "Surely, these Germans must be the most fearsome warriors in all the world!" he thought.

When he had taken his position on guard near the door of Cæsar's tent, he was surprised at the demeanor of the young nobles, previously so light-hearted, who now came and went. As an ominous stillness had fallen over all the camp, he could hear snatches of the talk within the tent.

"I need to return to Rome to attend to a lawsuit that I have before the courts," Caius heard one of them say to Cæsar. "May I go with your permission?"

"I fear not," he heard Cæsar reply coldly and firmly. "Your actions make it appear that you will be of small use here, but if you go, others will wish to go, and thus my army will be demoralized. You must stay. Go to your tent and take heart."

Others came to the tent with hope, and left in despair. Among these was Lanius. "Will the noble Cæsar permit me to return to Rome?" Caius heard him ask. "I have a large investment which demands my attention."

"I cannot spare you, Lanius," Cæsar replied. "I shall likely meet the Germans in battle soon, and as they are most terrible enemies, I shall need all my brave friends."

And Caius thought he caught a note of sarcasm in Cæsar's voice.

When Lanius passed from the tent, his head was 
drooping, his eyes were fastened on the ground, and his face was working convulsively.

"How like you being a soldier now, Caius?" asked Cæsar, who came after a while from his tent.

"Sir, I hardly know," replied Caius. "I did not get to fight in the Helvetian battle, and if these Ger-

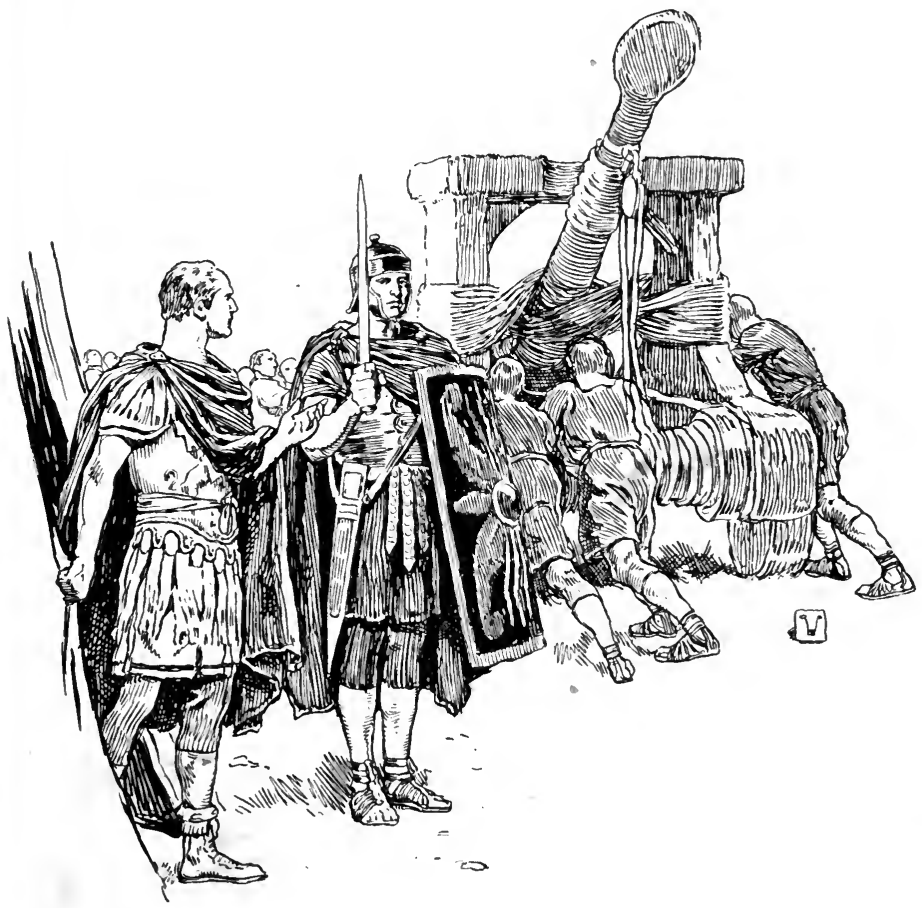

mans be so dreadful as they say, I fear I shall have to fight more than I wish."

"Ah, well, dangers lessen when approached," smiled Cæsar. "As we easily overcame the Helvetians, so shall we defeat the Germans. And I promise you that 
when we next join battle, you shall have opportunity to try your arms."

Caius was soon relieved from guard, and as he was leaving Cæsar's tent, he was joined by Baculus. The centurion was quiet and had little to say, but his face showed firm, strong, and fearless.

"Tell me about the Germans, Baculus," said Caius. "Are they really so dreadful ?"

"I do not know," replied Baculus. "But if Cæsar marches against them, we shall soon learn. Of that there can be no doubt, and if we all go down to Hades, across the much-ferried Styx, it will only be surely soon instead of mayhap late. I think Cæsar and his five legions can conquer all the Gauls and Germans between the Alps and the sea."

"Do you think our legion will fight well in battle, Baculus?" asked Caius.

"Yes, by Hercules," snapped Baculus. "It must fight. I shall see that it fights or falls. It must show itself worthy of Cæsar's favor."

Caius, though he had not felt the panic displayed by many of the others, nevertheless was reassured and felt more cheerful. As they passed down the long lines of yellow leathern tents, they drew aside several of the flap doors and looked in. On the ground in one, the men lay huddled, in abject fear, bemoaning their fate. One wretch was praying the gods to save them all from slaughter by the fearsome Germans. In another tent the men were making their wills and writing last messages to relatives and friends. In still another they saw Lanius weeping and muttering prayers to all the gods, and vowing to dedicate one of his Roman 
villas to them if allowed by Cæsar to go to Rome before the next battle came on. And so in all the tents were men given over to panic fear and black despair.

"By Pollux!" blurted Sannio, whom they met at the door of their own tent. "What is to become of us? It seems that there is no escape from these Germans. What are we to do? I think there is little plunder to be taken from them, anyway."

"Fight them is what we shall do, plunder or no plunder," said Baculus, sullenly. "And when we finish with them, if any of the legion be left alive, Cæsar shall say the Twelfth can be trusted.'

Then the bugle sounded the call for the whole army to assemble. The soldiers, as they moved toward the prætorium, presented' a shamed and whipped appearance.

When they had collected, Cæsar calmly mounted his earthen tribunal. He coolly began to censure some of his officers for the reasons they had urged why he should not march against Ariovistus. Then he spoke to the men somewhat thus: "Fellow soldiers, why should you show so much dread of Ariovistus and his Germans, anyway? In my consulship, only last year, did not that king come to the City and most eagerly plead for the friendship of the Roman people? Was it not granted him?. Why, then, should any one so rashly judge that he will now be recreant to his alliance and his duty? As for myself, I am fully persuaded that just so soon as my demands are made known to Ariovistus and their justness is clear to him, he will repudiate neither the favor of the Roman people nor even that of myself. And though he should be led on by rage and madness to begin a war, why should you fear him ? or why should 
you despair of your own former courage? A test of this enemy has already been made within the memory of our fathers when the Cimbrians and the Teutons were destroyed by Caius Marius, at which time the army seemed to deserve no less praise than the commander himself. Indeed, these are the same Germans whom the Helvetians have very often fought and vanquished. But you have lately seen that we easily vanquished the Helvetians, who were by no means a match for our army." And thus Cæsar soothingly reasoned, and ended by saying, "Now, I did not at first mean to advance at once, but at present it is my fixed intention to move the camp forward to-morrow at dawn so that I may learn as quickly as possible whether obedient duty or shameful cowardice rules you. If no man else will follow me, I shall go alone with the Tenth legion. I have no doubt of its loyalty and courage, and it shall be a body-guard for me."

The soldiers of the Tenth legion shouted their cheers, and their chief centurion was seen briskly stepping forward to thank Cæsar for the compliment and to assure him that the confidence in the legion should not be abused.

Caius felt his heart sink at being in a legion thus slighted. Old Baculus some little distance away blurted out, "By Hercules, the Twelfth can be trusted, too. I shall see that it can."

As Cæsar had said, the army advanced at dawn, and for seven days it moved forward toward Ariovistus. At the end of that time, the two armies were about twenty miles apart. 


\section{CHAPTER III}

\section{THE SOLDIER SAVES HIMSELF BY FLIGHT}

"Ariovistus now sends messengers to say that he is ready to hold a conference with Cæsar," said Procillus to Caius, Sannio, and Baculus, coming into their tent at night of the seventh day's march. "He claims that as Cæsar has now come nearer to him, he can meet the Proconsul without danger.'

"I should guess that he is rather beginning to think that he may be compelled to meet Cæsar with very great danger," laughed Sannio. "He seems not to know exactly his own mind about this matter. Sometimes it is one way and sometimes another, as said the countryman who lost a spotted pig."

"Well, I only hope we may have a battle, so we can show Cæsar that the Twelfth legion is as deserving of trust and honor as the Tenth," said Baculus, ignoring Sannio's effort at humor.

Caius said nothing. He rather wished if there must 'be a battle, it might be fought with the Gauls and not with the Germans. In fact the latter seemed more like friends because they were hostile to the Gauls, his own enemies.

"When is the conference to be?" asked Sannio.

"On the fifth day from this," replied Procillus. "Ariovistus demands that he and Cæsar shall meet, attended only by cavalry. So I fear none of us will be permitted to go." 
“What!” exclaimed Baculus. "Surely Cæsar will not trust himself to his cavalry. Every man of them is a Gaul, and would wish nothing better than to betray him, they are so uncertain and fickle."

"No," said Sannio. "You may be sure he will not do that. But he will do something that will cause you to open your eyes. Just wait and see. Listen! I hear an owl. That is an omen of evil to some of us." And he changed a large ring from one of his hands to the other.

On the morning of the day appointed for the conference with Ariovistus,Cæsar had the soldiers of the Tenth legion to dress as Gallic cavalry. He then mounted them upon the horses of his Hæduan cavalry. Procillus was summoned to go as interpreter. Baculus, Sannio, and Caius, despite the knowledge that they were in a new and untried legion, nevertheless felt a jealousy of the Tenth they could not well hide.

"Cæsar has done more for us than he promised," said a soldier of the Tenth, as they went galloping out of the camp, bumping with much awkwardness and pain on the backs of their horses. "He promised to make us prætorians; he has made us knights." A burst of laughter from the soldiers of the Tenth legion, loud but broken with the jolting, greeted this sally.

"And you are making ridiculous clowns of yourselves," yelled Sannio to him, as they bounced past where he stood guard. "May Pluto take you every one! You look like donkeys on housetops.'

That night Procillus gave the three friends an account of the meeting with King Ariovistus. The wily old German had demanded that they meet on the summit 
of a knoll situated in the midst of a considerable plain. The cavalry of each was left about two hundred paces away, and each leader went to the top of the hill, attended by only ten men. Cæsar then explained his demands to Ariovistus again, and Ariovistus haughtily

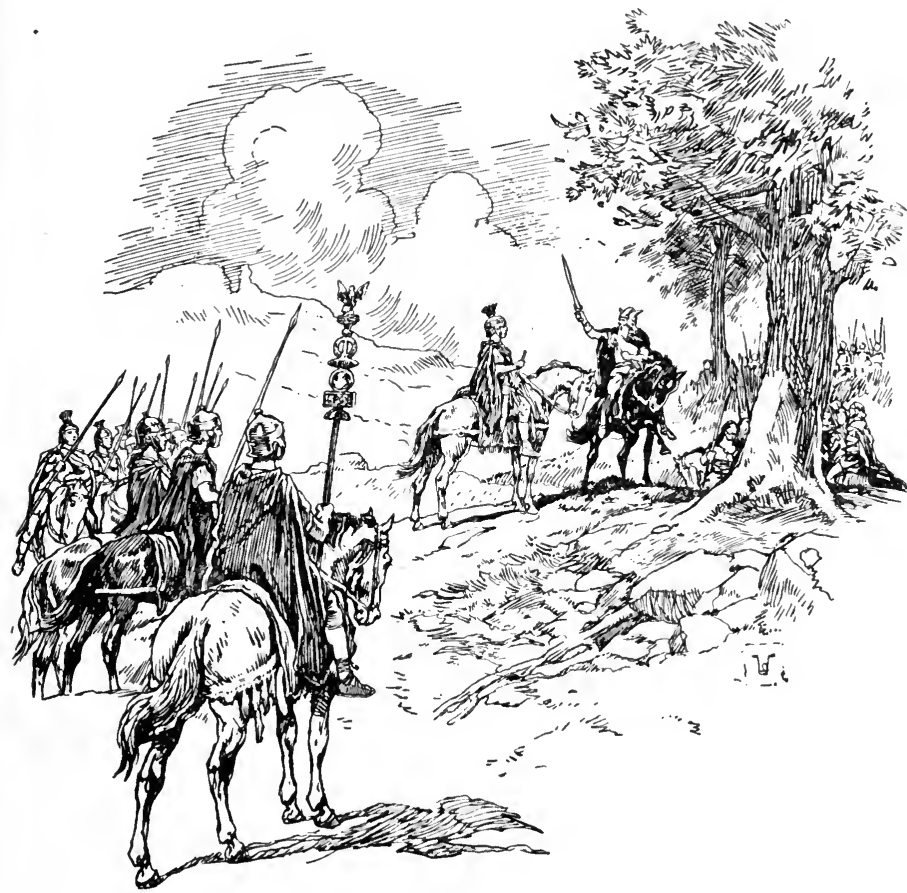

refused them, and spent more time in boasting than in trying to arrange for peace.

The Germans soon discovered that Cæsar's horsemen were not the Gallic cavalry they had expected. Enraged at the deception, they began to ride around the Romans and to cast stones and javelins upon them. This 
ended the conference, for Cæsar hastened away to prevent his men from beginning a fight with the Germans. He knew he could easily rout them, but he was unwilling to do anything that would furnish the least ground for the imputation of treachery. Cæsar had then returned directly to his own camp.

There now seemed no doubt among the Romans that a battle was impending. A great eagerness for it sprang up in the camp when the soldiers were told how insolently the German king had spoken to Cæsar. Preparations for battle were made and all previous doubt and fear vanished.

Two days later Ariovistus again sent messengers to Cæsar, saying that he wished to finish the discussion which they had begun in the former conference. Cæsar saw no further reason for parley with the Germans. But he nevertheless decided to send Procillus and Marcus Metius to learn what Ariovistus wished to say.

Sannio and Caius were detailed by Cæsar to go with these two as guards. Procillus and Sannio with a driver went ahead in one chariot, while Caius and Metius followed in another.

"I like not this business," said Metius when they were well out upon the way. "I once lived for some time in the household of this King Ariovistus. He is a bold, rash man. He hates the Romans, and it is by no means certain that he will give Cæsar's messengers a pleasant welcome."

"He is not likely to do them harm, surely," guessed Caius.

"Ah, that is uncertain," replied Metius. "I once saw him cleave the skulls of two Gallic messengers in 
his own tent because he was angry at their nation for not paying him tribute. For my part, I wish I were left safe in Cæsar's camp."

They drove rapidly on over the rough road, over the gently sloping country, seeing here and there small groups of thatched huts of the Rauracians, through whose territory they were passing. But for the most part, the land had been stripped bare of all crops, flocks, and homes by the hordes of the Germans in their passage.

About noon they approached the summit of a long, wooded ridge. Here they saw stretching far away in opposite dirctions, a line of wagons and heavy carts, placed close and bound together by chains. Beyond rose the smoke of innumerable camp fires.

As they drew nearer, they saw great numbers of hugebodied Germans within the line of wagons, while near a narrow opening in the line stood a small guard of armed men. In a space cleared of trees were playing hundreds of fair, curly-haired, blue-eyed children, for the most part bare of any clothing.

"You now see the German camp," said Metius. "Be ready to act quickly. We shall soon know the outcome of this venture."

Metius, knowing the German language well, hailed the guard and was soon signaled to approach. After some parley Metius returned to the chariot, and then he and Procillus went into the German camp. Caius and Sannio were not near enough to hear what was said after the two men were admitted within the lines formed by the wagons. But soon a loud uproar of harsh and guttural voices, mingled with the 
jangle of arms, rose upon the air, and then they saw great numbers of huge, fair-skinned men come rushing from the gate toward them.

"They mean to take us!" cried Sannio. "About! Let us fly! Drive, Caius, drive!" .

Caius waited for no second bidding. The foremost Germans were almost upon them before they could turn the chariot and get started. To add to the danger, they saw a number of horsemen dash out from the camp and come clattering after them with shouts and yells.

The drivers guided, and Caius and Sannio lashed the horses to their utmost run. The Germans on foot were quickly left behind, but those on horses rapidly gained upon the Romans.

"Drive, Caius, drive, as hard as ever you can!" shouted Sannio again. "There is a short cut through the hills. Some of them may head us off. Drive for life !"

Some five or six of the horsemen steadily gained. One hurled a javelin. It sang like a great arrow, barely missing Sannio, and passed between the two horses, doing no harm. Another javelin from a stronger hand struck quivering in the chariot bed in which Caius rode. Sannio cast a heavy Roman javelin, and the horse of the foremost German pitched headlong on the road, making an obstacle on which the next two tumbled in a squirming, kicking heap. The two latter, both horses and riders, quickly recovered, and all came on breakneck speed again.

"Hurl your javelin if you must, but first of all drive, Caius," shouted Sannio. "We must get away if we can. We are too few to fight."

The foremost German, a giant in stature, hurled his 
javelin. It sang in the air and struck Caius's driver square between the shoulders, and he pitched screeching from the chariot, dragged by the reins and bumping and knocking cruelly on the rough places and stones in the road. Sannio's javelin whizzed, and the huge German fell and was quickly pounded into a lifeless mass of bleeding flesh by the rushing hoofs of those behind.

The horses of Caius's chariot now began to be unmanageable. Sannio's chariot dashed up near his on the right. "Caius, when I slow up and give the sign, quickly change to this chariot," shouted Sannio.

The Germans had dropped somewhat behind, on the fall of their huge leader, and seemed to be planning. Caius now watched Sannio's every move. Soon they came to where the road made a sharp turn to the right. Sannio here gave Caius the signal to make the change, and at the same instant he pierced Caius's right-hand horse with a javelin. The poor brute, screaming piteously, plunged at length on the road, thus stopping the other horse and the chariot, and blocking the way. Caius quickly leaped to the other chariot, and then they were again rushing onward, while their pursuers were momentarily checked by the wreck of Caius's chariot. "What shall we do now ?" said Caius, seeing that besides their swords no weapons were left them excepting a single javelin for each. This state of affairs was what the Germans had expected, and now they were coming on like the wind, though their number had thinned to three.

"We must save our remaining weapons until we are compelled to use them," replied Sannio. "Hold on to 
the chariot and keep a good heart. We are now drawing near the place where the hill road comes into this, and we may have more enemies waiting for us there."

After a few minutes more of hard riding, they were in sight of where the hill road came in. No living thing was to be seen.

"Perhaps we have been too swift for them to head us off here," said Sannio.

On clattered the chariot and nearer pressed the Germans behind. Now the chariot was passing the end of the hill road, and now two Germans, breathing thick and running hard, dashed out upon them. One of them seized the bridle of the horse on the left. He was of such huge size that his weight caused the horses, though running their hardest, to swing around in a circle. As they did so, the horsemen came up. One of their javelins laid out one of the Romans' horses. Sannio let drive with his javelin, and the German who had killed the horse pitched gurgling and cursing to the ground, the long heavy shaft straight through his breast. As the chariot swung about, Caius had cut at the second man on foot, and he felt a fierce and savage delight in seeing that breathless warrior tumble in a heap, limp and loose, his arm and whole shoulder split almost from his body. Just then another javelin sang, and Caius felt a sting in his side and heard a tearing noise.

Meanwhile Sannio leaped down from his chariot and with his sword had stabbed another German, and then the horse of another from beneath, and it had fallen, pinning the rider to the ground. The last 
German, seeing himself alone, now betook himself to the woods, leaving his horse.

"By Pollux," panted Sannio, "but we have had some hard work with no plunder. What's that? Are you hurt, Caius?"

"I think it is nothing," replied Caius, as he examined a red smudge spreading on his white tunic. "A javelin barely nicked my side. No harm is done."

"We surely would have had it if the last two had been fresh and strong," said Sannio. "But we must get away from here. Others may come on at any moment."

They now found that the driver was wounded and hardly able to move. They laid him on the chariot, and Sannio now caught the horse of the German who ran away. The animal stood well enough to be harnessed, but he was no sooner hitched than he began to plunge and rear and kick. Sannio had the reins and called to Caius to get into the chariot. They then sped forward, the new horse plunging and trying to quit the road, but the other, a heavier horse of Roman breed, held him in place.

They reached the camp about an hour after dark. As they drove up Caius was sure he saw Lanius and Eredox together in the crowd of merchants and peddlers outside of the camp walls.

Inside, Caius and Sannio reported to Cæsar. "By Jupiter! the barbarians shall pay the penalty for violating the laws of embassies," said Cæsar, quietly. And then he gave orders for Caius, Sannio, and even the driver to have special attention given their hurts and hunger. 


\section{CHAPTER IV}

\section{THE SOLDIER FIGHTS IN A GREAT BATTLE}

"By Hercules, but fortune slights me sorely," complained Baculus, after listening to Caius's account of their escape from the Germans. "Here I am left out of everything that smells of a fight. I got tired of soft living and joined Cæsar's army, expecting hard fighting. And now here I've been in Gaul some three months, and nothing yet. I missed both the battles with the Helvetians, and even the little adventure yesterday. I wish I had been with you, boy," he went on, speaking to Caius. "I would have shown you how to fight them."

"We showed them, didn't we, Caius?" laughed Sannio, good-naturedly. "We got away from the whole German army, and killed a part of it, besides. The Germans have twice played Cæsar treacherous. I guess old King Ariovistus knows he can't conquer Cæsar in battle. So he takes every advantage he can. When a man can't beat his mule, he whacks the packsaddle. And, Baculus, you should have seen Caius. He acted like a veteran."

"Come, don't flatter me, Sannio," said Caius. "I was glad enough when that last fellow took to the woods."

"I was sorry enough we didn't have time to take the armor and horses of those two we cut down," said Sannio, with a long face. 
"Well, if there is no fighting soon, I think I shall be like some of Cæsar's friends. I shall have urgent business at Rome," said Baculus, with a meaning smile.

Just then the sentries on guard raised an alarm. Hurrying from their tents, as did the thousands of other soldiers in camp, they saw, a mile away, moving past them, a vast mass of men, carts, wagons, and animals. Almost immediately scouts brought news that this was the army of Ariovistus, and that it was encamping on a chain of heights about two miles away, with the purpose of intercepting the supplies of grain which the Hæduans had promised to furnish Cæsar.

"I begin to believe that you soon will have your wish, Baculus," said Sannio, as they stood and watched the trooping thousands. "If Cæsar does not join battle with this Ariovistus inside of five days, I shall no longer claim to know anything of him."

"So be it," grunted Baculus. "I am ready:"

On the next day, Cæsar marched his army forth and drew up a line of battle about halfway between his own camp and that of Ariovistus. Cæsar thus offered combat, and after the Roman manner had his camp to fall back upon in case of need. But Ariovistus refused the proffer, not allowing his men to come out.

And in this way, for five days, Cæsar offered, and Ariovistus declined battle. The Roman legionaries, having lost all fear of their enemy, were full of anticipation, expecting each day the greatest battle of their experience.

On the sixth day, in order not to be cut off longer from his grain supplies, Cæsar chose an elevated point 
about two miles from his own camp, and about half a mile from that of the Germans, and sent a force of men to make a smaller camp upon it. The Twelfth was one of the legions sent, and with the Tenth and Eighth, it was posted to protect the others while they dug the ditch and built the walls.

This work began about sunrise and went rapidly forward. The legions on guard were drawn up in line facing the German camp. The Tenth held the center, with the Eighth on the right wing and the Twelfth on the left. This arrangement threw Caius, Baculus, and Sannio not far from the center of the line, and almost directly in front of where the new camp was being built.

About the second watch of the day, a large troop of horsemen was seen to issue from the German camp, and advance.

"By Hercules," snorted Baculus. "I do believe here is going to be something to do at last. Now, fellow soldiers, now is the time to make a name for the Twelfth legion."

Caius in his place, six ranks from the front, watched, wide-eyed, with breathless interest.

On, swiftly on, came the black-clad, white-skinned Germans. At a distance of three hundred paces from the Roman ranks, they slowed and quickly formed themselves into a wedge-shaped body with its point toward the Romans. It was then seen that there were two men to each horse.

"Ho, ho, they are forming a swine's snout. They mean to root us out of Gaul with it," said Sannio. "See, Caius, the soldiers call that wedge formation 
a swine's snout. Its point, I think, is going to strike near us, too."

Caius heard a hoarse blare from hundreds of huge horns, and then he saw the German host roll toward the Romans like a black cloud. The young soldier's heart seemed to float in his throat like a hot liquid, and a great sickness almost overcame him. A youth at his side fainted, and a man two ranks to the front of him was heaving hard with nausea. Nevertheless, Caius felt an almost mad desire to dash to meet the on-coming wedge, but Roman discipline held him in place, quivering and gripping his javelin.

The command to cast their javelins now rang loudly in the Roman ranks. Caius, with thousands of others in the three legions, poised and hurled the heavy, steel-pointed shafts, and then for the first time he heard the whizzing swish and hurtling whine of the very storm of javelins as they glinted through the air, and fell rattling as they glanced, or thudding as they struck, on the wedge of men and horses.

Many Germans fell, some loose in death, others yelling and roaring with the pain of their wounds. Almost at the same instant when the javelins were cast the second man on each horse, a foot soldier, leaped down and with the others began to form small circles about the wounded and to remove them from danger. Meanwhile the advance of the Germans had not been checked.

They hurled their own heavy javelins, and many Romans were killed. Again the Romans cast, and again numbers of Germans toppled from their horses, and were quickly surrounded by their foot soldiers. 
And now the point of the wedge struck the Roman line almost in front of where Caius stood, and came crashing into it, overbearing rank after rank of the legionaries and crushing them to the ground, while

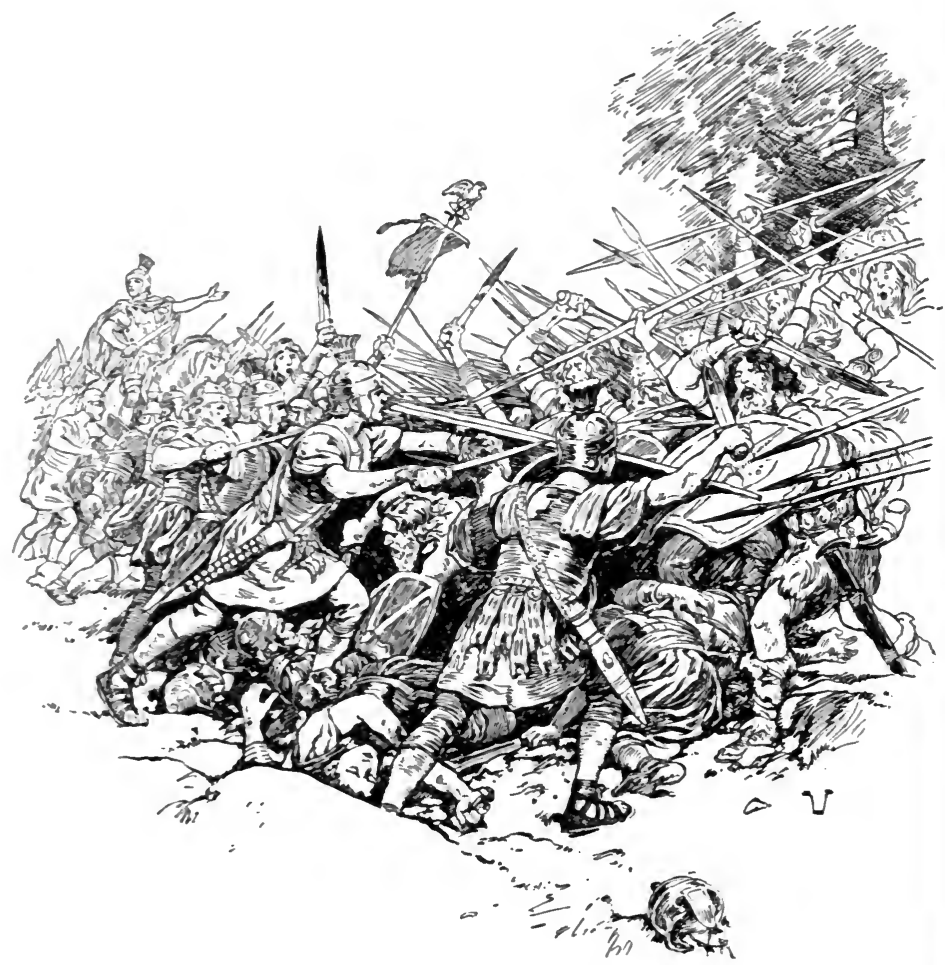

even the rearmost Roman ranks were driven backward by the terrific shock. Then the Roman short swords were out and passing back and forth, causing horses and riders to fall like grain before the scythe. It was not till the wedge had pierced almost through the entire 
first maniple that the force of the charge was somewhat broken. Indeed, Caius himself stabbed the foremost horse, while Sannio slew the rider as he pitched headlong on the ground.

The Germans hastily drew back, and formed their wedge behind those second men who had quickly passed between the horses to the front and had made a strong line to protect the horsemen. Then immediately the wedge rushed and plunged upon another part of the Roman line. But again it was repelled. Finally the Germans retreated, the footmen clinging to the horses' manes and easily keeping up with their hardest run.

Caius now saw that some forty of the men of Baculus's maniple were fallen. A few only were wounded, while most of the other fallen were crushed and mangled to death by the horses' hoofs. This left a huge gap in the line before him.

"By Hercules, but they came near killing all of my maniple," exclaimed Baculus, wiping the blood from a great cut on his face. "But by the Roman eagles, it was a pretty little piece of work, and the Twelfth will fight. Cæsar now knows that. I hope we shall see those Germans again soon. Are you hurt, Caius?"

"No, only frightened a little," answered Caius. "I believe I am not hurt so badly as you are."

"Ah, it is well that I came out alive," exclaimed Baculus. "Five of the rascals set upon me, and after I had slain three of them, it was only by good luck that I was able to hamstring another as he hung to a horse and got away with the rest."

The work was hindered no further, and the new 
camp was finished by one o'clock in the afternoon. Then Cæsar left the Seventh and Twelfth legions to hold it, and took the others back to the larger camp.

When the ranks of the first cohort of the Twelfth legion wère rearranged, Caius was advanced to a place in the first rank of the first maniple. This change put him under the command of Baculus, and was considered a promotion, for a Roman soldier was promoted from the rear ranks toward the front, and from the left of the lines toward the right. Caius now held a place in the front ranks, only eight places from the right, thus being near Baculus, his centurion.

On the next day, Cæsar again offered Ariovistus battle more persistently than before, keeping his men in line until noon. Seeing that Ariovistus would not fight, he then led his men back into camp.

Early on the third day after the new camp was made, Sannio returned to the tent from the quæstorium, where he had been to grind the corn.

"Well, Baculus," he said, "you are always wanting a fight. I think you will have one to-day. Cæsar means to force the Germans to a battle. When he consulted the auspices the sacred chickens came eagerly from their cage, the silence was silence perfect, and half the crumbs fell from the chickens' mouths as they greedily ate. The omen was good, and already the red battle flag hangs from a spear on Cæsar's tent."

"Suits me exactly," muttered Baculus. "I hope he won't change his mind."

And just then the tubas of all the legions sounded with a deafening blare for the legions to march forth and form in line of battle as on the previous days. Im- 
mediately the men shouted, "To arms! To arms!" the legions fell into place, and were soon outside of the camp in line of battle. The Seventh was on the extreme left, and the Twelfth next, while the others were in the center and on the right.

After the line was formed, Cæsar, on his great splayfooted horse, rode up and down the lines, encouraging his men, and urging them to remember all their former bravery and their hopes of future glory. Besides, he hinted, there might be some more substantial rewards, if the victory were won.

The order to advance was sounded, and then the line, more than a mile long, moved forward over the rocky, tree-covered ridges, toward the German encampment. On, right up to within a hundred paces of it, the Romans moved, and then halted.

"Come out," shouted a Roman soldier, "and make good the boasts of your insolent king."

"Come out and beat the mule," called Sannio. "You have whacked the pack long enough."

"Yes," roared Baculus. "We are ready for you."

And so hundreds of Roman voices cast insults upon the Germans, and the Germans hurled their taunts upon the Romans. And though their speech differed, each understood the other's meaning.

Cæsar was yet making some slight changes in his line, when a movement was observed among the Germans, and then they were seen to issue by thousands from numerous places in their lines of wagons, and quickly form their line of battle, having their wagons behind them as a rampart. On this wall of wagons the black-garbed women and the children were seen climb- 
ing, and then with flying hair, and with their white arms extended, they begged the men not to give them over to the Roman soldiers.

Now the German battle horns sounded loudly and harshly, the German line moved, broke into a run, faster and faster, and came on with a rattle, a clangor, and a clamor, that made the Roman veins swell almost to bursting with the hot blood pounding through them. At the same moment, the Romans dashed forward. So swift was the onset of each that there was no time for throwing their javelins. These were dropped, and with swords drawn, both lines closed upon each other with a horrid shock that sounded up and down the lines like a sudden burst of thunder over a hollow valley. The Germans had locked the front line of shields before them and the other lines above them, and formed their phalanx.

Caius, with an exhilaration he had never before known, had rushed with the legion upon the Germans. As the two armies had crashed together, he felt himself stunned and the breath almost crushed from him by the impact on the wall of hard shields. Recovering quickly, he found himself opposed to two huge German warriors, both protected by their shields and both striking at him savagely. With all the din and push and confusion, he barely saved himself with sword and shield. A fleeting glance as he dodged and parried showed him the Roman to his left fallen, with his blood and brains oozing from a cleft skull.

Baculus now called out, "Leap upon them, men, and tear their shields down." At once the Roman on Caius's right leaped, and clutched at the top edge of a 
German shield, and he was as quickly run through with a long two-edged sword. He fell, but a stream of dark blood was pouring upon the ground before his body reached it. Caius had only a glimpse of all this, for at the same instant, he himself had leaped upon the shiellds, and had only been saved from a like fate by the parrying of the soldier directly behind him. As it was, he caught the top edge of a shield with his left hand, and dragged it down. Two soldiers from the second rank had passed up beside him, and now all three thrust stoutly into the opening. A German fell, and in doing so, dragged down two other shields, thus exposing their owners. These two Germans were quickly stabbed, and the opening in the walls of shields grew.

Caius next found himself in combat with a single German giant, who swung his long sword, roared, leaped, cut, and thrust so swiftly and adroitly that Caius could scarcely defend himself. The young Roman, however, kept his head, made a movement as though to dash into the opening to the German's right, and when his antagonist whirled to prevent this, thus exposing his own left side, Caius's already bloody blade darted forward like an adder's tongue. He saw the German weaken, totter, and sink in a heap with the blood spurting from a gash in his side. And so the young soldier fought, now here, now there, until he was so weak and weary that it seemed he must fall and die among the litter of corpses that strewed the ground.

At last as he pressed half stupidly on, he became dimly aware of a Roman close at his side hard pressed by three Germans. A quick glance showed it to be Baculus. As the tide of battle had flowed somewhat 
away from the youth, he was not now engaged with any particular foe. So he quickly hurled himself upon the nearest of the antagonists of Baculus. As he did so, the German swung his long, heavy sword, and Caius must have been cleft to the teeth had he not parried with his own sword, upon the superior metal of which the German's weapon broke. Caius thrust, and the German fell. Baculus meanwhile had cut down another of his assailants, while the third betook himself to flight.

"By Hercules," panted Baculus, "I think that is once you have saved my life. They were about to get me, I believe. But look! they are leaving us."

Caius, clearing the blood and dust from his eyes, now saw that the whole German army was in flight. Far to his right he heard the thunder of Cæsar's Hæduan cavalry, bearing down upon the disordered barbarians. Dumnorix was proving that he could fight for Cæsar against the Germans, even if he had failed in the battle against the Helvetians. The Romans, too, broke into pursuit. Soon they came upon the line of wagons. Here strange sights met their eyes. A few of the women were yoking horses to wagons, trying to escape. Many more, the Romans saw to their astonishment, were coolly cutting the throats of their little ones, and then their own. The Roman soldiers butchered thousands of them, as they broke over the wagons, and then on, pursuing, hewing, cutting, hacking, stabbing, the flying Germans.

Baculus kept his cohort fairly well together. On, on, they followed, the whole army leaving behind it a track of dead, dying, plundered bodies. 
As Caius, Baculus, and Sannio pressed forward, they saw two Germans dragging a man who was loaded with chains on his arms and legs. He seemed half dead, and only moved because of his guards' threatening gestures with their brandished swords. The three hurried toward the prisoner.

"By Hercules," exclaimed Baculus, "it is Procillus. At them, and kill the cursed barbarian guards!"

Procillus was soon loosed from his guards and chains, glad to be free, but weak with exhaustion. A Hæduan of the cavalry gave up his horse, and Procillus was sent to Cæsar, who was as much delighted to see Procillus as he was to be victor in the battle.

As Caius and Baculus, in the long pursuit, reached the Rhine, they saw far out on the river a little boat. In it was a single huge man, struggling toward the opposite shore. Ever and anon, he was forced to cease rowing to beat off drowning wretches who tried to climb into his boat. At last he reached the shore, sprang out, and disappeared in the forest.

"Who is that man?" asked Caius of a German prisoner whom a Roman close at hand had taken.

"It is Ariovistus," he answered. 


\section{CHAPTER V}

\section{THE SOLDIER ASKS A QUESTION}

Night found Cæsar's army in the camp which they had left in the morning to fight the Germans. The shrieks and moans of the wounded might still be heard here and there in the tents, and still might be seen the flaring torches of the camp followers and soldiers' slaves as they went to and fro over the battle field, ever pulling and searching and plundering the bodies of the slain. The loud laugh, the rough jest, and the song of victory, all bespoke the joy that rioted in the Roman camp.

Most joyful of all, perhaps, were the Hæduans. They had seen the Germans, their cruel oppressors, beaten, and they had the glory of taking part in the battle that had destroyed them. They were now a free people once again.

The Romans were elated at having beaten an enemy so noted for courage, and they were delighted with the valuable booty that had fallen into their hands. There was not a Roman soldier but had some gold or silver ornament, taken from the body of a German, and scarce a Roman but held one or more German prisoners to sell as slaves in Italy.

Sannio, Baculus, Procillus, and Caius lay at ease on their cloaks in their tent, each happy in his own way Sannio, because of the extra share of plunder that he 
had taken from the body of a German chief; Baculus, wounded and weary, but gratified with all the fighting a day would hold; and Procillus, sick and sore, but once more among friends. Caius was proud because he had been publicly praised for his bravery by Cæsar, but he was still wondering at the cruelty and heartlessness of war. To the simple, kind-hearted boy, brought up on the Italian hills, with a task no harsher than the tending of sheep, the day's slaughter seemed a bloody dream, a horrid unreality.

"Procillus, tell us of what befell you among the Germans," said Baculus, as he bound a cut and bathed it with oil.

"Yes," Sannio joined in, counting over and toying with the trinkets of bronze and gold he had taken. "I thought never to see you again when we left you that day in the barbarian camp."

"You are a brave soldier to leave a mate like that," said Procillus.

"By Pollux, did you want me to storm the whole German army?" asked Sannio.

"No," said Procillus. "I was only teasing. You could have done nothing more than lose your life. As to what happened, it is rather a long story. More happened in a short time than you would think. If you fighting men can remain long enough awake, I will try to tell you all."

"Yes, tell us," they urged.

"As soon as Metius and I were in the camp, we were led past the sacred trees upon which were nailed the heads of many Gauls, an offering to Woden, before Ariovistus. He no sooner saw us than he shouted 
aloud, in the hearing of his whole army, "Why have you come into my presence? To spy out my men and strength?' We began to speak to give him Cæsar's message, but with horrid oaths and fearful threats he forced us to silence. We expected instant death, so dreadful were his gestures and countenance. Then he ordered chains fastened upon us, and we were dragged from before him.

"But he soon forgot us, I suppose, for he was even then making ready to march his army toward Cæsar. As Metius was known to Ariovistus, he fared better than I, and his chains were taken off, though he was kept under guard. I was dragged on foot by four strong men the entire distance of the march. My limbs were cut by the chains and dripped blood at every step. I had no water and was almost starved.

"When the Germans at last camped for the night, about six miles from Cæsar's army, I dropped on the ground, nearly dead with weariness and exhaustion. I quickly fell into a feverish sleep. Soon I dreamed, and it seemed a beautiful maiden was rescuing me from scorching flames. Then a soft touch that was real cooled my forehead and awoke me. In the half shadows, just apart from the light of the camp fires, a German maiden bent above me, offering me a horn of water. I drank greedily the cooling draft. With a smile she left me, and I slept again.

"But I was not to be allowed this luxury; for I was soon dragged up by a big warrior and carried before a sort of court of German women. It is the custom of the Germans to consult their women whenever any important business is to be undertaken, and the women 
in their turn cast lots or try omens. The Germans have the greatest respect for their women.

"These women coolly set about casting lots to find out if the gods would decree that I should be burned

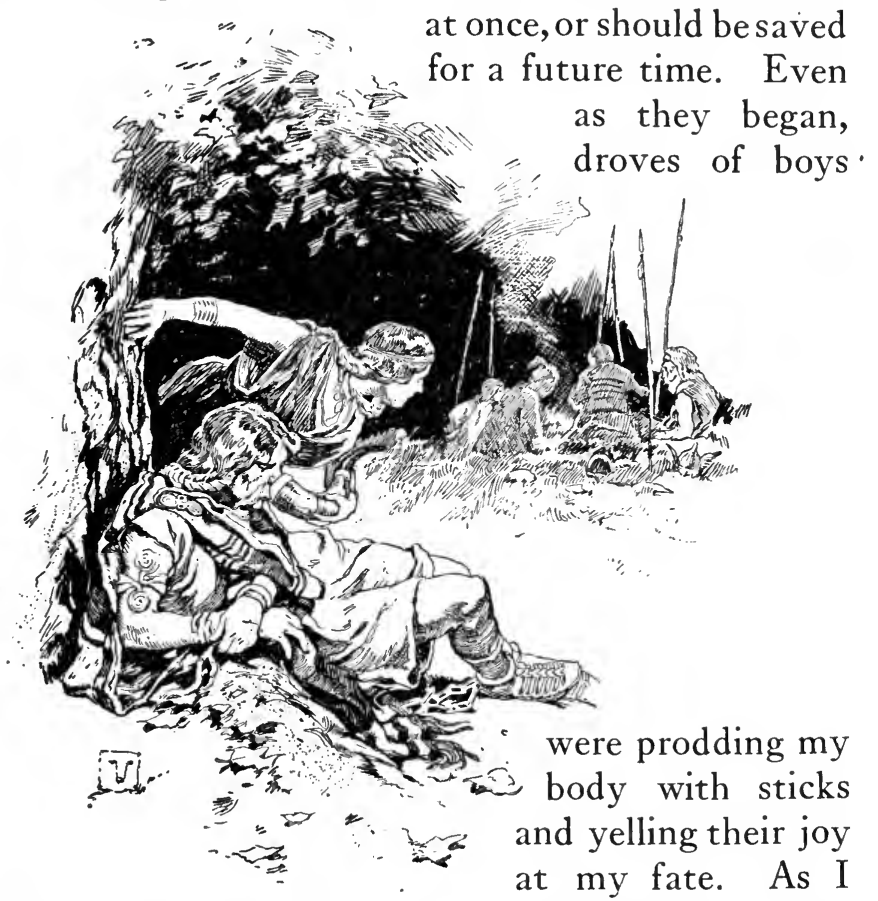

know their language, I understood all that they said. 'See the big fire to burn you,' shouted one bull-necked youth. "'That's what we will do for all the Romans we do not kill in battle,' yelled another.

"Yes, we'll cut off the food supplies of the Romans, starve them, and leave not one alive,' shouted yet another. And so I learned what they meant to be my fate and also that of the Roman army. 
"Soon all was ready for the trial. My gaze was fixed on the quiet face of the maiden. Just before they were to draw lots from a helmet filled with beans of different colors, I saw her remove the helmet from which they were to draw, and replace it with another by a move so deft and swift as to escape all notice. I did not understand the meaning of this action at once. But as the lot was in my favor, I was sure she had placed a helmet of beans all of the same color."

"What's that?" broke in Sannio, starting up, forgetting to play with his plunder.. "Was our bold Procillus made a double captive, fast in the iron chains of the enemy, and in the silken bonds of Cupid?"

"Oh, be quiet," snapped Baculus.

"Didn't you get to fight any of them, Procillus ?"

"Not fairly," answered Procillus. "One of these women, a lean, stooped, wrinkled-faced old hag, now stood forth, and in croaking tones, long and dolefully drawn out, wailed to the men the decree of the lots: 'It is not the will of Woden, Thor, Friga, and all the other gods that dwell in the bright city of Asgard that this man, our foe, shall be burned this night.'

"Then the men were enraged, and a great angry uproar swelled through the camp. One of my guards struck me. I was so angered that I hurled myself upon him, and slung my arm chains with all the force I could. They struck on his head, and he went down, bloody and groaning. But he was quickly up, and I think he would have run me through, but his companions laughed at him, and said, 'Good enough for you. Now don't take advantage of a man loaded with chains, even though he be an enemy.' 
"I expected that they would kill me the next day, because I knew we were so near Cæsar's army. But they did not, I suppose, because they were so sure of a victory. 'If the gods are unwilling that he be put to death now, so much the better. We shall have many of his fellows to go with him after we beat Cæsar's army,' they said.'

"Why did the Germans refuse the battle offered them the next day?" asked Caius.

"Because their women prophesied, and said that it was not the will of the gods for them to conquer if they fought before the new moon. So they were waiting for the moon to change," answered Procillus.

"Well, Cæsar couldn't change the moon for them, but his army removed the light from thousands of them," laughed Sannio.

"Did you see the maiden again ?" asked Caius, innocently.

"Here's the bold youth who wants to know more of the fair maiden," laughed Sannio again.

Caius colored deeply and said nothing.

"Yes, I saw her again," replied Procillus. "They cast lots twice again to learn if I should be burned. Twice again I saw the maiden, by the same movement, save me."

"And is she the same maiden that you were so determined to rescue from those two Roman soldiers who had captured her, as we were going to Cæsar's tent after we found you ?" asked Sannio.

"Yes," returned Procillus. "She had saved my life, and so I was eager to save her when I found her in the hands of the soldiers. I have learned that she is Hilda, 
the daughter of Ariovistus. She was most dear to the old barbarian king, and it was at the risk of her own life that she was so kind to me. She is now kept among the hostages in the camp, under the care of the wives of the Roman officers, who have dared to come to Gaul with their husbands. Cæsar has promised me that she shall be sent beyond the Rhine to her kinsmen among the Germans."

"So you expect to see Hilda again?" asked Sannio.

"I may," replied Procillus. "Now, as to the rest of my adventures, you already know them."

And then, though the groans and shrieks of the wounded, and the shouts of roving bands of plunderers, and the call of the sentries still broke harshly upon the night, the friends soon slept soundly. 


\section{CHAPTER VI}

\section{THE SOLDIER IN WINTER QUARTERS}

THE Roman army remained here for three days for the purpose of disposing of the dead. The bodies were piled in long rows and their arms with them. Into the mouth of each was placed a coin for Charon, the ferryman of the Styx. The lines were piled with branches of oak and laurel. On the third day Cæsar publicly eulogized the deeds of the slain, then the other soldiers bewailed and lamented them. Next the bodies were covered over with fagots and burned. The ashes were sprinkled with wine and placed in long trenches and covered with earth.

The thousands of German bodies lay unburied. At night droves of snapping, snarling wolves gorged upon the blackening flesh, sneaking and slinking here and there like ghostly shadows. The morning of the second day brought black clouds of vultures that fed and croaked and made the scene too horrid for words.

As Cæsar had finished two great wars in one summer, he now determined to lead his army into quarters for the winter. So upon the fourth day after the battle, when the sickening scent and revolting scenes of the field had become unbearable, the army marched northward. The long line, undulating like the billows of the sea, wound away through the hills, on which the green of the trees was already giving place to the brilliant hues of autumn. 
After several days of march, a place was reached in the country of the Sequanians, designed by Cæsar as a home for the army during the winter. Here Cæsar placed in command his most trusted lieutenant, Labienus, while he himself with a small retinue set off to Cisalpine Gaul to hold the courts of his province.

The greater number of the young friends of Cæsar who had come to Gaul for adventures now left for Rome, not caring to forego the gayeties of the capital to endure the rigors of a Gallic winter. Most delighted in this number was Lanius. As Caius was busy helping to build the log huts which were to shelter the soldiers during the long nights of winter, he saw Lanius among a troop of those passing forth, joy showing on every feature. "Come, Caius," he shouted as he reined in his horse. "You had best go with me to the City. There, I am a free man among free men. I owe no man and shame to face no man. I own three villas there and much money. I feed twenty crops, six dogs, and a couple of horses. Come with me. We will have pleasant times there this winter.'

"I give you thanks," replied Caius. "I care not to go. I remain here in order to be a better soldier for next summer's campaign."

"Every man to his taste," returned Lanius. "It will be too dull here for me. There will be games and shows and wine and women, all sorts of pleasure at Rome for those who will take - and as for me, next summer may look to itself." And with that, he dashed after his companions, his bright, bordered toga fluttering in the breeze, while Caius continued laying the poles to make his hut. 
"He would most likely poison you, anyway," grunted Sannio. "I have heard it hinted that his father got his wealth by murder in the times of Sulla."

Caius soon learned that winter in a Roman camp was far from being a period of rest. He worked day after day in helping to build a high wall and to dig a deep, wide ditch about the camp. Then, too, Labienus proved himself an unrelenting drillmaster. Though it was customary for every Roman army to drill each day during winter under long sheds built for the purpose, Labienus had it done with such persistent thoroughness that Cæsar could write the next summer that "the men understood as well how to direct themselves as they knew how to take orders from their commanders."

Toward the last of the winter, it was necessary to travel farther and farther from the camp to find forage and provision. One day when the first tender green of spring was softening the landscape, Caius was sent with some twenty other soldiers commanded by Baculus to make demand for supplies wherever they could be found.

This search took the party beyond the territories of the Sequanians, among the Senones. Toward night of the sixth day after leaving camp, as they entered a village, they saw a crowd of the townsmen collected about three or four huge carts to each of which were hitched two of the large, white, long-horned oxen common in Gaul. The animals stood quietly chewing their cuds, but the Gauls seemed much interested and rather excited.

As the Romans came up, they perceived that the carts were those of a number of Roman traders who 
were carrying a load of Gallic bacon to Massilia. The inhabitants of the village had, according to the Gallic custom, stopped the traders to ask questions as to where they had been and what they had learned and whom they had seen and what they whom they had seen had told them.

The Gauls at once turned their attention to the soldiers, fearlessly gathered about them when they had halted, and began asking questions.

"Where have you come from?" asked a Gaul who seemed to be a leader.

"We have come from the Roman camps of Cæsar," answered Baculus.

"What news from there?" asked the Gaul.

"All goes well, friend," answered Baculus, "except provisions for Cæsar's army grow scarce. Can we depend upon the people of this noble city to peaceably furnish us some supplies?"

The Gaul was taken somewhat aback, though this very request was what he had reason to expect, for news of the foraging of the Romans had spread far and wide, long earlier in the winter.

"That will have to be decided by our magistrates," replied the Gaul. "I will report your wants, and a meeting will be called to answer you. Meanwhile, our townspeople will feed and shelter you for the night."

As the Senones had previously made peace with Cæsar, Baculus had no fear of spending the night in the town, and so he was just giving orders to the men to disperse to the various houses, when Caius felt himself plucked by the tunic. He turned and was surprised to recognize the old merchant, Matho. 
"Is Caius, the young soldier, well ?" he asked. "All goes well," replied Caius. "And how fares the good merchant of Ravenna?"

"My health is good," returned the merchant, at

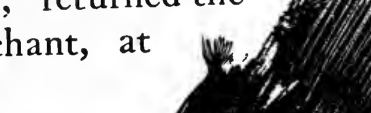

the same time laying his finger on his lip and pulling Caius aside. "Hush, and come a little

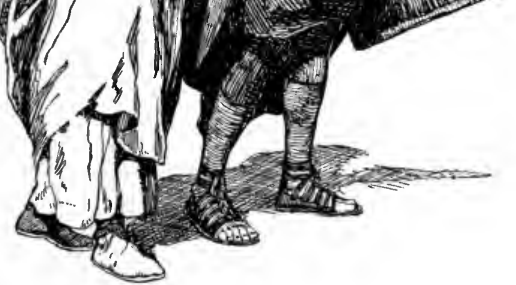
apart. I wish to speak with you." And while the men were being disposed of, he continued rapidly in a low tone. "There is trouble abroad, but I am sure it is useless to tell Baculus, what I know, for he thinks he and Cæsar can overcome any difficulties whatsoever. It were not wise to scatter this handful of Romans in the town, for almost the whole of Gaul is now plotting against Cæsar. I have learned that an embassy of Belgians will arrive 
in this town in a day or two for the purpose of persuading these people to join in the conspiracy. If these Romans are separated from each other, it is likely enough you will each be separated from his head long before morning."

Already the soldiers were moving away in various directions to their assigned quarters. Caius rushed to Baculus and rapidly told him all he had heard. "The old merchant, Matho!" snorted Baculus. "He of the Ravenna inn? He always finds danger. What if these Gauls should try to harm us? One good Roman soldier can put to flight half a legion of Gauls."

Caius felt the rashness of this view, and argued with the centurion, even against the rules of discipline.

Baculus tried to pretend anger, and asked, "Do you know the first and last lesson a Roman soldier must learn?"

"Yes," replied Caius. "It is obedience, and I am ready to yield obedience, but I am sure you have not thought carefully of this matter.'

"I am sure you have not thought at all," returned Baculus, "else you would not stand arguing with me instead of hastening to obey. If I report this conduct to Cæsar, your career as a soldier will be speedily ended. He demands absolute obedience to officers from every man. Nevertheless, I will recall the men and we will all sleep in the frosty air of the public square." And so he ordered the trumpeters who stood near to sound a recall.

Baculus placed his men in a close knot and set a watch of only one sentry. The soldiers knew nothing of what the merchant had told Caius and soon they all slept. 


\section{CHAPTER VII}

\section{THE SOLDIER LEARNS OF A PLOT}

But Caius could not rest, and lay long awake. He seemed to hear a stealthy tread over all the town as though its inhabitants were going about to plot the Romans' death. Once, away on the outskirts of the town, he heard a barking of dogs, and then a clamor of voices. After a time all was still again, and he slept. But not long, for he was awakened by a heavy groan. Springing to his feet, he saw the sentinel fallen on his face, writhing and kicking, while the form of a man leaped away from him and ran for the shelter of a near-by house. Caius shouted at the top of his voice. Then a fearful uproar swelled on the night air, and from behind the house where they had massed themselves, hundreds of townsmen sprang out upon the little Roman band. As the soldiers had slept armed, they quickly sprang up to defend themselves, but they were stupid with sleep and stricken with surprise and the terror of the unknown.

"Steady, men, stand firm, and let them have your sword points," shouted Baculus, as he stabbed the nearest Gaul.

The legionaries made a great effort to stand, but they were quickly rushed backward by force of numbers. Four or five Romans were cut down, and though for each of these at least five Gauls lay kicking in the dust, still 
it was impossible for so few to stand against such numbers.

" Keep together and retreat slowly,” Baculus ordered, but the Gauls pressed up more and more, and soon the Romans were scattered and running for life among the huts of the town.

Caius found himself surrounded, and seemingly with little chance to escape. A big Gaul had almost struck him down with a heavy blow on the head, and it seemed to him he was spinning around like a top. However, he struck out boldly at the nearest of his enemies, and by good fortune disarmed him. Taking quick advantage of this, he ran into the man with such force as to send him sprawling on the ground, while he himself dashed straight ahead, not knowing where he went. He was rapidly pursued, but he soon dodged into the shadows of a hut, and his pursuers passed by on the farther side of the house. He stopped and stood close in a corner, waiting and listening.

The whole place was a tremor with the barking of dogs, the shouts and swift running of men, the groans of the wounded, the screaming of women and children, and a thousand other noises and echoes set flying on the stillness of the night. Away on the outskirts of the town, Caius heard the blare of the Roman tuba, and he knew that a number of the Roman soldiers had escaped in a body and were calling to any who were lost or scattered to come to them. Then he heard it more faintly and he realized that the little band was getting farther away. But as men were still passing near him, he feared to stir. So he remained quiet in his place, waiting for the chase to go by. 
Finally, when the noise had nearly subsided and he was beginning to think of making a run for his life, he heard men enter the hut, speaking in Gallic. His hand sought his sword hilt, but it was not there; he had dropped it in his dash through the line of Gauls. $\mathrm{He}$ was helpless and defenseless. Since he could do nothing else, he lay still. As he had learned to understand many of the dialects of the Gallic tongue, he began to listen.

"By Tarann, but we gave them a scare and a chase, didn't we?" said one.

"Yes, but this night's work will bring Cæsar's army upon us," said another, whose voice sounded strangely familiar.

"No, Cæsar will not dare to lead his army this far into Gaul," said the first speaker. "Even if he should, did not these Belgian ambassadors who came in during the night say that the Belgians are just ready to send an army against Cæsar? and did they not say that all Gaul has been secretly organized against the Romans? and if so be the case, what have we to fear? If Cæsar should-dare to lead his legions all these hundreds of miles, we should, quicker than the lightning can flash, cut them in pieces."

Caius listened intently now to this extravagant talk, all thought of escape forgotten in the hope that he was learning something of value to Cæsar. He knew the Proconsul was in Cisalpine Gaul, holding his provincial courts, in the belief that all Gaul had been pacified.

"No, you do not know these Romans," urged the familiar voice. "A defeat stirs them only to more 
determined efforts. This town will suffer for this night's work before Cæasar stops, mark me."

"Yes, but I tell you now what we have heretofore kept secret from you, for our people thought your long stay in Italy had Romanized you. Listen: all Gaul has conspired with these Belgians against Rome. Cæsar will speedily be driven from Gaul. We may even march against great Rome.herself and camp on her hills as did our ancestors under the brave old Brennus, the greatest leader in the world."

"You need not have feared me," said the familiar voice. "I was born in this town, a Gaul, and a Gaul I remain, though Gaul, divided as it always is, has no chance against the system and unity of Rome. Well, I see I can't convince you of your folly, and you are too mean and stingy to bring out your wretched mead to wet a starving throat. I'll go and get a wink of sleep before the day comes." And as Caius lay closer in his corner and watched the man come out, and swagger away, he recognized old Eredox.

Everywhere, quiet had soon fallen. Then Caius, gathering up all his courage, slipped quietly along in the shadows of the houses, taking as near as he could the direction in which he had heard the Roman tuba. He had not gone far, before he found himself obliged to cross a narrow street in order to continue in his direction. In making a swift dash across in the darkness, he stumbled over a dead body, lost his footing, and tumbled heavily forward at his length upon the ground. His hand fell upon a long Gallic sword. He grasped it gladly, for even as he lay, he saw running upon him a stout, armed man, as Caius thought, a 
Gaul brought from a neighboring house by the noise of his fall. He leaped quickly up, and thinking it useless to run, he grasped the sword hilt in both his hands and swung it at the other's head with all his might, and so stretched him out on the ground. Then taking to his heels, he ran with all his might straight ahead, he did not know where nor how far. When weariness at last forced him to halt, he was in a forest of oaks. At the foot of one of the trees he fell, gasping and panting for breath.

Birdswere chirping and the woods were gray-

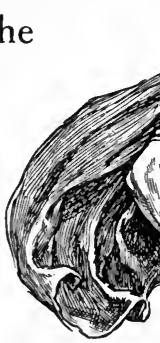
ing with the dawn. The young soldier. 团 had scarcely begun to breathe with any

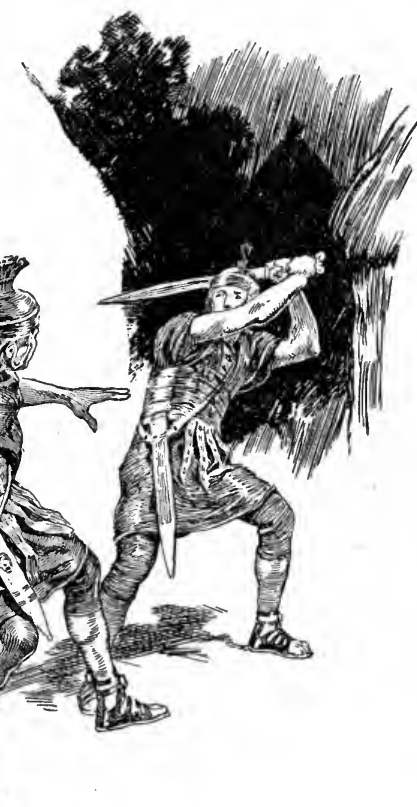
ease, when he saw through the dim light, at a little distance away, a man skulking among the trees as though he feared to be seen. Caius quickly rolled behind the trunk of a giant oak, and peered at the figure, now going past him at half a javelin's cast. It was Baculus.

Caius leaped up and ran toward the centurion, but Baculus gave him one wild look, and took to his heels, 
making his best efforts to run. However, he moved but slowly, winding and staggering as he went. Caius followed more rapidly, calling to him.

"By Hercules, it is Caius," exclaimed he under his breath, as Caius overtook him, seized his arm, and whirled him around. "I thought a Gaul or a ghost had me."

"What are you doing and why do you stagger so, Baculus?" asked Caius, in wonder.

"Well, when our little body got away and stopped in those woods yonder, I found you were among the missing," explained Baculus. "I feared you were lost or dead and I went back to that cursed town to look for you. I sneaked through all the place, hunting, and just as I found you, and before I could speak, you swung up your new Gallic sword and gave me a whack over the head with it. I would have been a dead man had it not been for my good steel helmet. As it was I lay senseless for a time, I know not how long. Like a brave soldier you ran away and left me, and here I am staggering like a winebibber. But I don't much blame you, even if you had known it was I whom you swung at so stoutly," he went on gloomily. "You tried to warn me and I wouldn't listen. It would have served me right if a Gaul had split my head with one of those big long swords. Now I am in a pretty fix to report to Labienus, and much more to report to Cæsar."

Caius now began to understand. It was Baculus he had struck down when he stumbled over the dead Gaul. $\mathrm{He}$ remembered now that he had vaguely wondered as he ran why a Gallic helmet of bronze had rung under his blow like a Roman steel one. 
"Well, Baculus," he said, "I am glad we are alive. True, it was bad enough we were tricked by the townsmen, and bad enough that we ran like rabbits, and bad enough that I lost my sword, and worse that in my fright I tried to kill my best friend. But perhaps you will agree with me that none of it is as bad as it might be. Besides, while you thought I was lost, I was hid by a hut hearing one Gaul tell another of the conspiracy which is being formed against Cæsar." And Caius briefly related what he had heard.

"By the legion's eagles," exclaimed Baculus. "Cæsar will think it more worth to know this than to have all the provisions in the whole town. We must hurry to camp and report this matter to Labienus." And even as he spoke he led Caius away, down a narrow hollow between the hills, and soon they came to where a sorry remnant of the legionaries were awaiting the return of Baculus.

Caius recognized his old friend, the merchant Matho, sitting somewhat apart from the soldiers, with gloomy downcast visage.

"I have lost all my goods and wagons, friend Caius," he exclaimed in reply to the inquiring look of the young soldier. "And I am now an old man. I shall starve in my age and helplessness." And he began to bemoan his fortune.

"Never mind, my good fellow," said Baculus. "You will never be the worse. Come now, and bethink yourself. Is there not some near route by which we may reach the camp of Labienus?"

There was, and guided by the old merchant, the little party set off at once, traveling at their best speed. 
They soon found a number of Gallic ponies tethered in a meadow near a small village. The soldiers caught these, and, mounted horseback, moved more rapidly. The old merchant, leading the way, sat his horse but awkwardly, and as they went on, he alternately bemoaned the loss of his goods and the discomfort of travel on horseback, while Baculus never ceased to express the hope that an occasion would speedily arise when he might blot out the memory of his rashness by some brave deed. 


\section{CHAPTER VIII}

\section{THE SOLDIER IN BATTLE WITH THE NERVIANS}

As the sun rose dim over the foggy marsh lands of Belgium, the tuba blared its call to march, the legions formed in columns of maniples, the signal to advance sounded, and the long line swayed forward.

Caius stepped with pride into his old place near Baculus. He had only the night before overtaken the army; for, after carrying to Cæsar, in Cisalpine Gaul, the message concerning the conspiracy of the Gauls which Labienus had sent him with, Caius had been ordered by Cæsar to go to Bibracte on an errand which consumed several days. This errand done, he had hastened northward after the army. He had reached it too late for the siege of Noviodunum and several other engagements with the Suessiones and Bellovaci.

"There is likely to be something to do to-day," said Baculus to Caius, as the army swung briskly along. "We have been marching for several days with each legion's baggage following next to it. But note now that the six old legions come first before even a single baggage wagon. The change shows that Cæsar expects something. Indeed, a Gaul told me last night that we were then not more than a day's march from the Nervians. Well, I am glad. May the gods grant me a chance to make good my ill fortune in that country." 
"And I hope I may make amends for the blow I laid on your big old head," said Caius.

As the army moved on northward toward the territory of the Nervians, Baculus told Caius how Cæsar had hastened to Gaul after Caius had carried the information they had gained by their midsadventure. The centurion told how Cæsar had quickly led the army against the Belgian tribes and how the Remians had submitted without a blow, and how Cæsar had defeated the great army of Belgians who had attacked his allies in the walled town of Bibrax, and how the Suessiones had surrendered to Cæsar because they were alarmed by the quickness with which Cæsar built fortifications to attack their town, because they thought that the gods must be aiding men who could work so rapidly. "I tell you Cæsar strikes swiftly," went on Baculus. "That is one of his favorite ways. When another commander would keep some plan a secret for a month, Cæsar makes no effort to keep the secret, but carries the plan out before it can be understood. But from all accounts, the Nervians, whom we are likely to fight next, will prove more difficult to rout than any foes Cæsar has yet met in Gaul. The Remians say the Nervians are the hardiest and the bravest of all the Belgians. The Nervians were the only nation of all Gaul who were able to prevent the hordes of Cimbrians and Teutons from entering their territories." And so much talk passed throughout the army, each soldier knowing there was likely to be hard fighting soon with a tough enemy, but each so seasoned in the two years of service under Cæas that this was what he most desired.

The day's march had been slow and toilsome. For, 
besides the marshy nature of the lower ground and the roughness of the higher, the Nervians were accustomed to train young trees and vines to grow into a thick hedge; and by bending down the young trees and intertwining them, an almost impassable wall was formed. The Romans had to cut passages through these. About two hours past midday, the Romans came to the brow of a long ridge, overlooking a little valley, beyond which rose another parallel ridge crowned with a thick forest. Down the valley between these ridges wandered the Sabis River, a small and shallow stream.

The Romans halted and began to fortify on the slope of the hill the camp which had been measured off by the scouts and centurions sent ahead for the purpose.

As the Twelfth legion came to a halt, Caius saw a small advance body of Roman cavalry beyond the river, attacking a few horsemen of the enemy. The latter did not stay to fight, but retreated into the woods on the top of the ridge. As the Romans did not follow, the Gallic horsemen soon charged upon them again, and then again retreated into the woods' as the Hæduan cavalry of the Romans advanced upon them. These movements were continued for some time.

Meanwhile, the Roman legionaries began to be busy building the camp. But the men had scarcely broken ranks and piled their arms and baggage for the purpose when a mighty uproar of voices, the clashing of weapons, and the rush and tramp of thousands of running men broke upon the Romans' ears from across the little valley.

Looking up from where he was helping to place a 
heavy timber in the works, Caius saw that a large body of Romans had attacked the Nervians. Then he saw pouring in a stream from the woods on the top of the opposite hill, thousands and thousands of Belgians, pursuing with incredible speed and fury the Roman cavalry, which soon turned in headlong flight.

Soon the youth heard the signal for the soldiers to collect to their standards sounded by Cæsar's trumpeters, and the hoarse notes were immediately taken up and repeated throughout the lines with mad haste. This was quickly followed by the signal to array in battle order, and the tuba blared the battle call. The Romans came running from all directions, stopping at whatever standards they first reached in order to lose no time from fighting. Almost at once the Romans were roughly arrayed, each soldier taking position as best he could. The Ninth and Tenth legions were on the left wing. The Eighth and Eleventh were in the center, and the Seventh and Twelfth on the right.

By good fortune, Caius reached his old and regular place just as Baculus in his position at the head of the legion gave the order to the eagle bearer to stand firm and hold the eagle high. Looking hastily down the lines, Caius saw that the legion was lacking many of its men who had not yet returned from the work. Those who had succeeded in getting into line were mostly without their helmets, having had time to snatch only their shields and swords from where they had been piled.

Even while he was taking this hasty glance, the Hæduan horsemen of Cæsar dashed terror stricken, fleeing for life, to the right of the Roman army, disap- 
pearing from view behind a dense hedge of trees and vines, and closely followed by one of the three divisions into which the Belgian army had quickly separated itself.

There was hardly time to glimpse these happenings before the enemy had crossed the Sabis, climbed the hill, and was upon the entire Roman line. The Nervians fell upon the Twelfth legion in a solid mass, led by their king, Boduagnotus, a great, long-bearded, fair-haired giant, clad in heavy mail, and armed with a long double-edged sword. With hoarse guttural shouts the Nervians pressed upon the Romans, front and flank. There was no time for casting javelins, and the battle was joined hand to hand, cut and thrust.

The weight of the Nervian onslaught drove the Romans into a close-packed mass. Caius found himself stunned and almost crushed, and blows from the Nervian long swords falling about him so fast that he could scarcely stand. He had drawn his sword, but had no room to use it. The legionary to his right, a stout veteran of other wars, with a great heave and surge, cleared a small space, and in a flash had stabbed two of the Nervians, but this act had given more room for the wielding of the enemies' long swords. Three or four of them instantly crashed on the legionary's head and shoulders with such force as to split his head in twain, and his shoulders and arms fell from his body. He crumbled to the ground and was quickly trampled and crushed under foot. Into the space thus momentarily cleared, Caius was thrust by the press from the rear. He glimpsed a tall, well-built youth of about his own age, raging and roaring, springing upon him 
and aiming blows at his head. Caius had only time to partly cover himself before he was almost beaten down by his antagonist's crushing blows. But he recovered himself a little, and as the Nervian youth exposed himself for another swing, Caius's sword sought his side, a ruddy stream dyed the white flesh, and he fell.

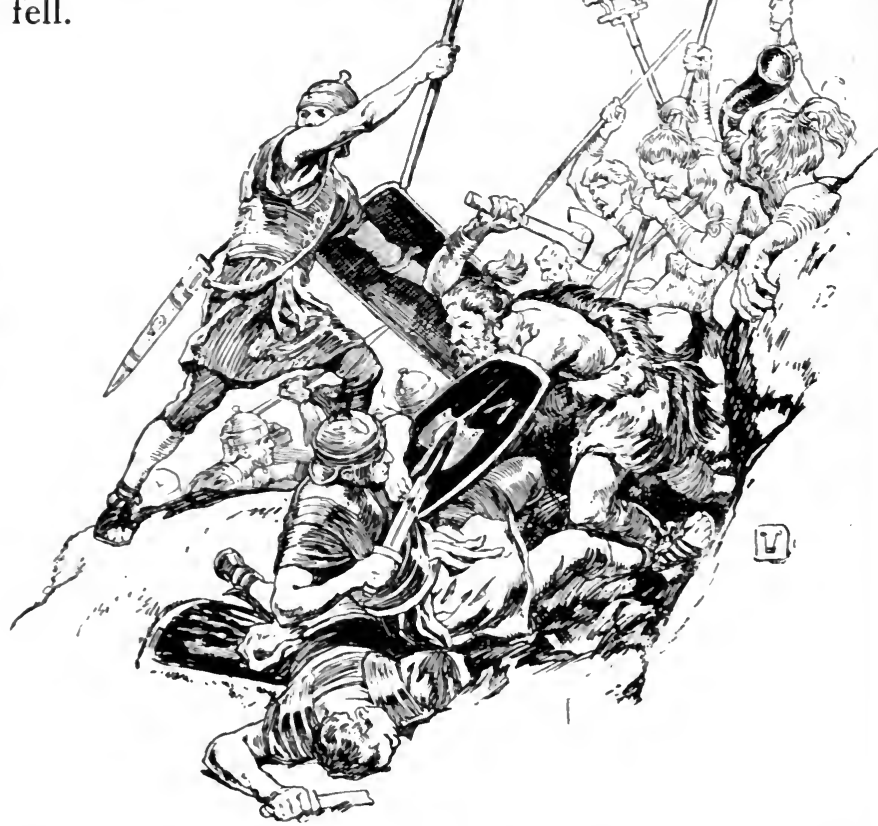

"By Hercules, well done!" And Caius, turning for a moment, saw Baculus beaten to his knees by King Boduagnotus, but the old centurion was still valiantly defending himself from the blows falling on his head. 
Caius now perceived that every one of the five men in the line between his place and that of Baculus, including the standard bearer, had fallen. He leaped to the aid of Baculus, while the press and surge and crush of panting, perspiring, bleeding men swayed the whole mass back and forth.

"Cæsar, Cæsar, Cæsar Imperator!" now arose the shouts of the soldiers. Even at the moment, Cæsar himself, in his scarlet cloak, rushed between the Seventh and the Twelfth legions to the front.

"Stand firm, fellow soldiers, and remember your courage and success in former battles. Loosen your ranks to give room for the use of your swords. Now, press forward, and strike," he was shouting in loud clear tones, at the same time cutting, thrusting, leaping, and defending himself with the utmost skill.

The effect on the legionaries was instant. The strong and uninjured pressed forward more stoutly, the weak took heart, the wounded endeavored to rise, those who had retreated came forward again, and all fought with such courage and renewed vigor that the enemy began to be checked.

Caius had at once snatched up the eagle and raised it in place, and also covered Baculus with his shield. The old centurion under this cover struggled to gain his feet. "O Mars, grant me the strength to fight till they fly,"' he gasped, and then fell again.

Boduagnotus had now ceased his attack on Baculus. But Baculus was disappointed in his hope of fighting the king, for the Romans now, in steady ranks, began to press the Nervians back, and Boduagnotus with a shout of defiance rattling in his throat fell by another hand. 
Cæsar hurried away to encourage the Seventh legion.

The battle was by no means ended. The Nervians in their desperation fought fiercely and tenaciously. Each Roman, feeling himself in Cæsar's presence, desired to do something more brave than any other, and so exerted himself to the utmost.

The ground was already strewn thick with dead. The long lines of Nervians stood upon heaps of corpses and fought as from a rampart. When their first line had been cut down by the Romans, the next foremost rank climbed upon the dead mass and fell fighting with the same reckless desperation.

And so the battle raged. The Roman short swords continued to work back and forth like the shuttles of a loom, seeking the sinewy flesh of the barbarians, letting forth blood and vitals; the Roman javelins from the rear fell on the heads of the Nervians, crushing their skulls, piercing faces, throats, and breasts, - all made a veritable shambles.

The Nervians stood their ground, wielded their heavy swords, and wrenched from the quivering bodies of their friends and brothers the Roman javelins, and furiously hurled them back upon the mailed mass of the legions. And steadily the heaping rows of dead rose higher until only a miserable handful of the Nervians remained alive. Then, at last, they broke and fled.

Meanwhile, Caius had held the eagle aloft and protected Baculus with the aid of some three or four legionaries that Baculus summoned to the defense of Caius and the eagle. When at last Caius was free to look about, he saw on both slopes of the valley 
Nervians fleeing and Romans pursuing. Here was a little group still resisting, there a single combat; in one place a body of Nervians entangled in their own carefully built hedges was being hacked to pieces, in another a handful of Romans was being hewed and split head to heel by the swinging swords of a larger body of Nervian horsemen. Everywhere the dead littered the ground, and where the fighting had been fiercest, lay thick-heaped windrows of huge golden-haired bodies.

As the setting sun threw its last glimmering rays over the little valley, it lighted the Romans completing their camps, despoiling the dead, and carrying away their wounded.

Caius tenderly lifted Baculus and the eagle and bore them into the camp. 


\section{CHAPTER IX}

\section{THE SOLDIER BEFRIENDS A NERVIAN YOUTH}

ON the next morning, Cæsar called all the soldiers to an assembly and praised them generally for their courage and fortitude. Many of the officers he praised by name.

"Procillus," said he, "though born a Gaul, has demeaned himself as a true Roman in that he checked the flight of our cavalry under Dumnorix, that had fled so ignominiously; and thus helped to bring victory out of defeat. The centurion, Publius Sextius Baculus, I commend most heartily. I found him fallen with many wounds in the thickest of the fighting, but still leaning upon his shield and battling stoutly. Sannio showed a cool head, and helped to win by his courage and example." And so he praised others in degree varying with their deeds.

"As to Caius Volcatius Tullus, since he raised and sustained the eagle of the Twelfth legion when it and its bearer had fallen, I now promote him to be aquilifer in the Tenth legion. You all, fellow soldiers, know the change from one legion to another is not according to custom in the Roman army. But this youth deserves much of me. I know of no greater honor that I can bestow upon one who has proved himself so worthy than to make him aquilifer, and let him be bearer of the sacred eagle, the emblem of Jove, in my beloved 
Tenth legion. Caius, I promote and commend you. May you never let the eagle fall.'

A great shout of applause rose, for the youth had come to be a favorite with great numbers of the legionaries. However, a few of the older soldiers of the Tenth grumbled somewhat because of the promotion over themselves of a younger man from a newer legion.

Next, the spoil was divided. The old merchant, Matho, was present and received a liberal share in reward for his efforts to aid the cause of Cæsar by giving information. The old man was happy once more.

During the day, Caius walked into the woods, away from the sights of the battle field. He sat after a time resting, for the exertions of the yesterday had wearied his whole body. As he thus sat, there passed through his mind proud thoughts of his new honor, of the bountiful share of spoils he had received, and of the help the latter would be to his mother. Then he thought of Simmias and Chloe and Titus and the dog and the sheep. So thinking, he grew lonely despite the singing of the birds in the trees, and the blossoms of the spring everywhere. He suddenly realized that he had not even Baculus with him to talk to.

He shook off his lonely thoughts and started to return to camp. But hearing the shouts of soldiers, he looked and saw, passing through the woods at a javelin's throw, a band of Roman legionaries. As they were moving rather slowly, he thought there must be something unusual. So he approached and learned that the soldiers were bringing to Cæsar a number of old men, women, and children of those Nervians who had 
been hidden in the marshes and fen lands. They were to be hostages, pledges to Cæsar that the Nervians would be no further trouble to him.

Caius joined the party. In crossing a bog, he came upon a youth of slender form and good features who

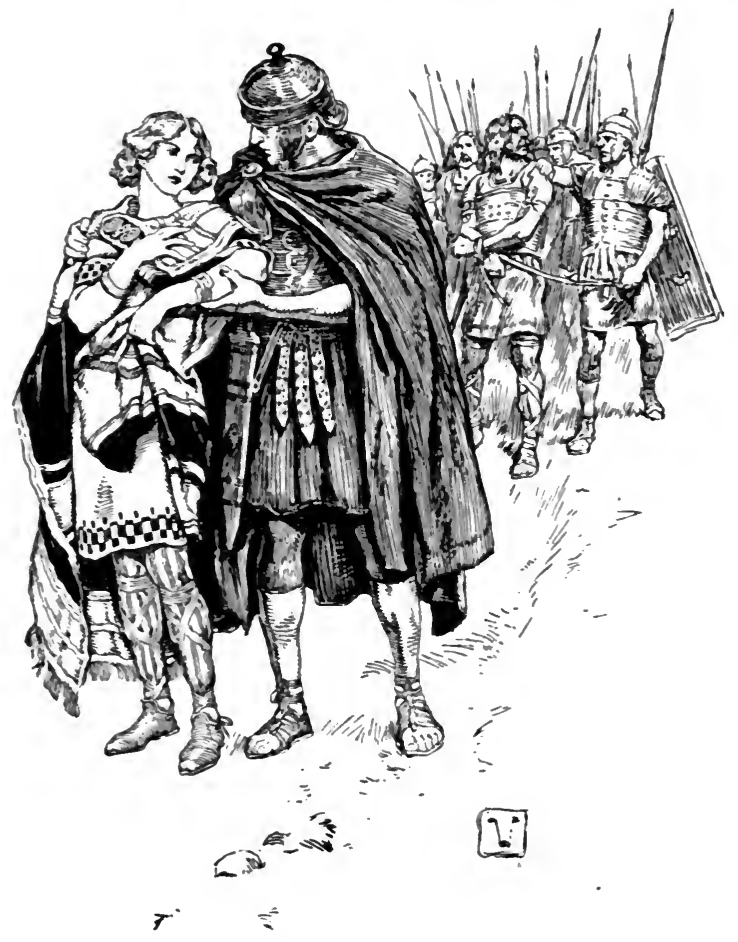

had fallen. A soldier was beating the unfortunate youth to force him to rise and go along with the others. The youth was making the greatest efforts but could not rise. Caius remonstrated with the soldier, but the latter, with an oath, told Caius to go about his own 
business, at the same time raising his hand for another blow. Caius warded it off the youth, and the soldier then struck at Caius, but Quintus Pedius, the legatus who was in command of the party, came up and ordered the soldier to desist and march on.

As the young Nervian now looked up, Caius saw a tear in his eye, and his heart was touched with pity. Caius aided the youth to his feet, and then supporting him, they went on among the others to the camp.

"I give you thanks, noble Roman," said the young Nervian, in broken Latin. "I was wounded in the battle yesterday, and, besides, I am faint with hunger, and so had fallen."

"It is nothing," said Caius, looking closely at his companion, and wondering at his unusually delicate features and small hands. "But how comes it," he went on, "that you wear the dress of a Nervian and yet speak the tongue of a Roman?"

"Oh, I learned a little of your language from a Roman trader when I was small," replied the other. "I am a Nervian, as you see, and I fear I am to be held as a hostage."

And so Caius walked on, supporting the youth until they were at the entrance of the Roman camp. While they were waiting to be admitted, the rearmost portion of the company passed up. Caius, standing with the youth, became aware of the presence of the stout Nervian whom he had fought in the battle the day before. Caius had thought him dead, and looking now more closely, he perceived that the Nervian had many wounds and bruises. Caius started with surprise at the glare of bitterest hatred which the Nervian 
warrior was darting upon him. But he ceased to wonder as soon as he reflected that every Roman might expect only hatred from a Nervian, éspecially from one who had been personally worsted in combat.

When the party at last marched into camp, Caius remained outside. The wounded young Nervian, having recovered sufficient strength to walk alone, stopped to say "Farewell" to Caius, and spoke with such gentleness that Caius somehow wished he had gone on with him.

After staying in Cæsar's camp four or five days, till Cæsar was ready to move his army, these hostages were to be sent away for safe keeping. Caius had meanwhile seen his Nervian friend only at a distance. He determined to have a last word with the youth. So he waited near the camp gate where the party was to pass out.

At last the hostages were marched forth, with sad faces and unwilling steps. The Nervian saw Caius and stopped a minute to thank him. "Farewell, kind Roman," he said in a low voice. "We meet no more. You were good to me, and I shall not forget."

Something in the tone, the movement, the smile, opened the Roman's eyes. "A maiden," he muttered as he gazed after her. "Worse still, a Gallic maiden."

And then with set face and swift steps he turned away to where the blare of the tuba was calling the legionaries to make ready for march. 


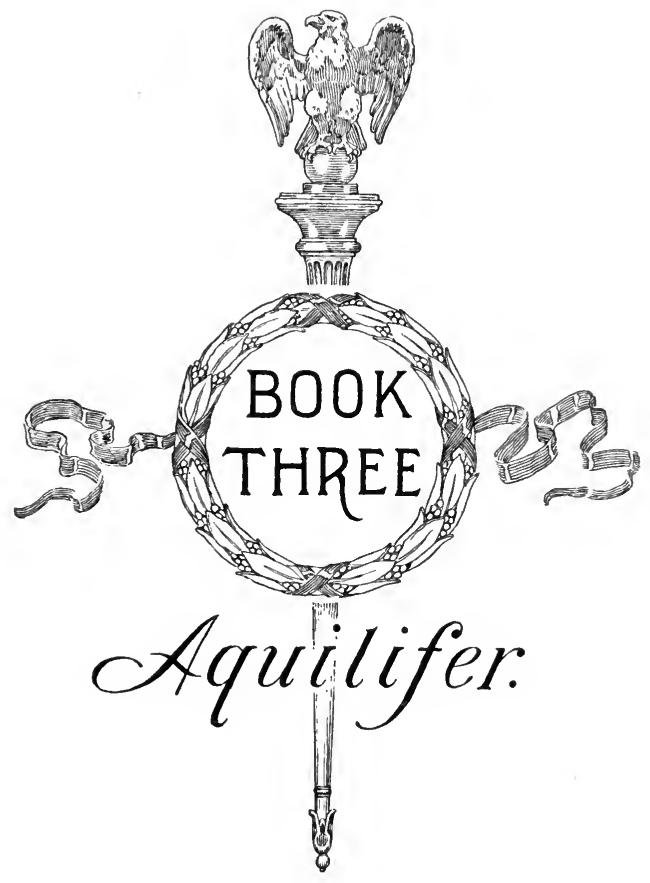




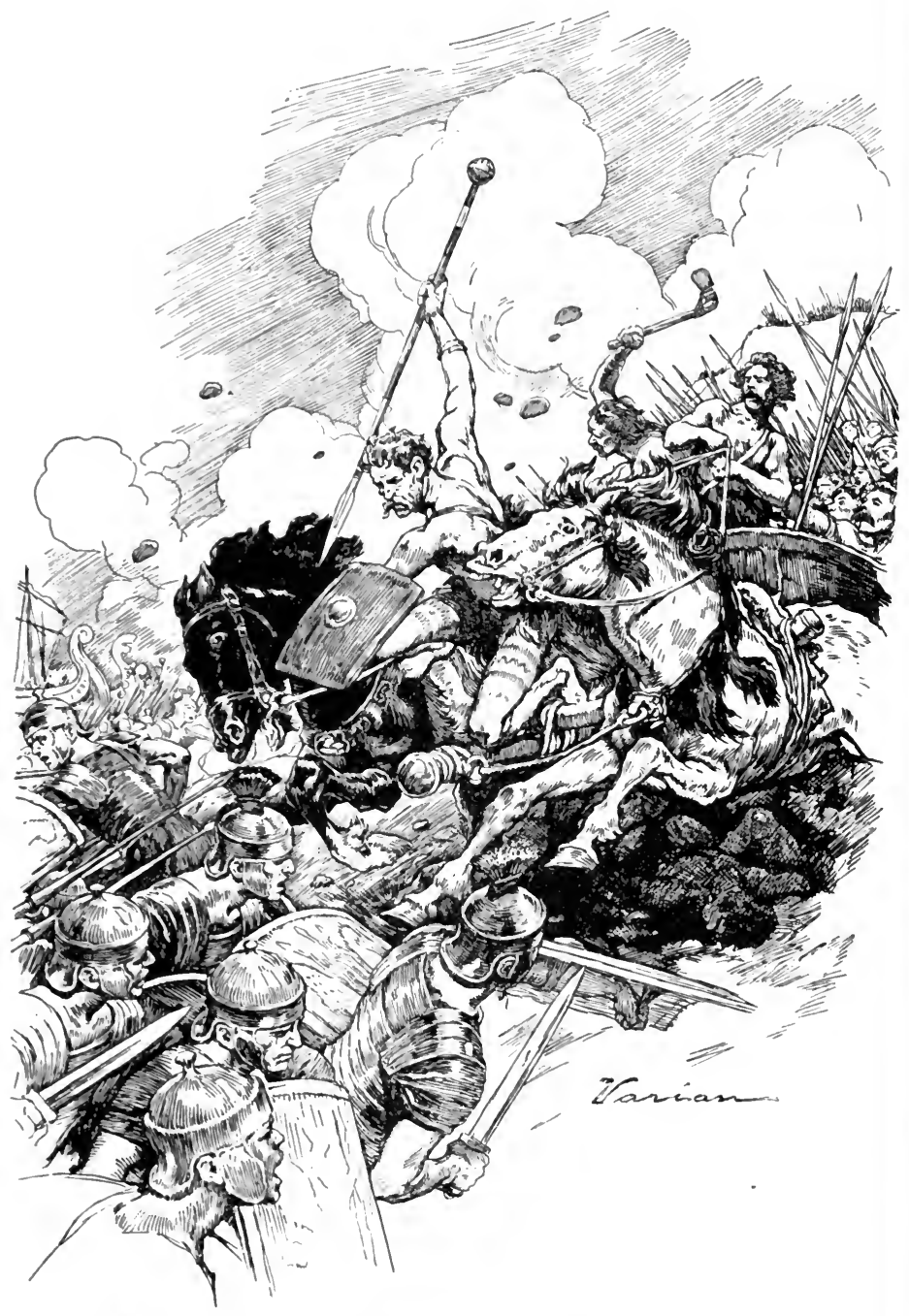

The Standard Bearer is lost Sight of in Battle 


\section{CHAPTER I}

\section{THE STANDARD BEARER CARRIES A MESSAGE}

Some months later, in the afternoon of a spring day, Caius, followed by some twenty or thirty horsemen, rode rapidly into Luca, a town of considerable size in Northern Italy. He was weary and dust covered. It was now twelve days he had ridden with only few and short rests, from Labienus and the Roman army quartered in the country of the Sequanian Gauls. He bore important letters from Labienus to Cæsar, relative to a fresh conspiracy which spread apace throughout all Gaul.

As he passed along, the youth was struck with surprise at the number of soldiers, traders, petty officials, and plainly clad citizens and laborers that thronged the narrow streets. He halted long enough to ask a soldier where Cæsar was lodged.

"Hard by the forum," replied the soldier. "You must be newly arrived from a distance not to know where the Proconsul of Gaul lodges."

Caius deigned no reply, and was just spurring forward, when the crowd through which he was now forced to push his way with difficulty, opened up, soldiers and citizens removing their head coverings, and bowing respectfully to a procession which was approaching. This movement of the throng showed to him a man wearing a toga with a broad purple stripe. He was borne by slaves in a chair, and was 
preceded by six lictors, one after another in a row. They were loudly but solemnly shouting, "Make way for the tribune, the tribune Caius Trebonius approaches."

The youth was just pulling his horse to one side in order to pass when one of the lictors who had now come even with him and his company, roughly laid hand on his bridle, and commanded him to dismount. Feeling the importance of his message and the need for haste, Caius spurred his horse, and it leaped forward. But he was quickly stopped again by the command of a lictor.

"Dismount," commanded the lictor, "and show respect to the dignity of a tribune of Rome."

The chair of the tribune had now come up, and he began to question the lictor. "This rude soldier dares to ride breakneck speed past you, and will not dismount," explained the lictor.

"Why show you such lack of respect to the dignity of a Roman tribune, my worthy man?" gravely inquired the tribune.

"Sir, I am but a soldier from Gaul, not used to the customs of the city," replied Caius. "I meant no disrespect. Besides, I am hot with haste to bear important letters to Cæsar. I pray you will allow me to proceed."

The tribune's manner at once changed. "If that be the case, I beg your forgiveness and urge you to go on at once. I also trust that I may have the pleasure of a talk with you during your stay at Luca. You will find me at the house of Cornelius, the prætor of the city. Pray come to see me there." And with a. gracious smile, he waved Caius a farewell. 
Soon the young soldier reached the forum. He found it crowded with all manner of folk. The rostra were covered with the various products of Gaul. Here a Roman merchant examined a mass of gold or bronze brought from the mines of Aquitanian Gaul, and there another looked with care at a stack of salted hams of swine. In another place a trader tested the strength of some Gallic cloth of linen which was on exhibition, and next to him, a Roman knight was admiring a suit of chain mail forged by the Gauls of Gergovia. Near by, a group of Romans, rustic in appearance, but plainly prosperous, examined a yoke of huge wide-horned, Gallic oxen, hitched to a heavy Gallic cart. And on all sides the various products of Gaul were being viewed by Roman farmers, soldiers, artisans, merchants, magistrates, and senators.

"By Ceres," he heard one farmer say to another, "we have thought all the time that the Gauls were a poor nation, without any of the things that make Italy so fair and rich."

"But we are mistaken," said a wine merchant. "I find over there on the left a sort of mead made from wheat and honey. Its taste makes a man wish he had a neck as long as a javelin. The Gauls have many things that are worth the while."

Caius pressed now in the direction which had been indicated to him as being the lodging of Cæsar. He had gone but a few steps, however, when he saw the Proconsul in company with a number of distinguished-looking Roman senators, clad in their purple-bordered togas.

Cæsar saw the young soldier advancing. He motioned Caius to him and asked his errand. 
"I bring letters from Labienus," replied Caius. And he handed them to the commander.

"Very well, come to my quarters at the third hour, and tell me the news," said Cæsar. "I am now occupied."

Caius, after having ordered his attendants to quarters indicated by one of Cæsar's officers, mingled with the throng in the forum. He soon learned from the talk everywhere that the products of Gaul were on exhibition here to show the Roman nobles the importance of the country and the real value of the victories Cæsar was winning in Gaul. Every one knew in a general way that Cæsar was here to meet the rich Crassus and the famous Pompey, relative to some important step that meant much to Rome. But neither Caius nor those to whom he listened knew what or how.

Caius found that he had an hour before the time at which he was to go to Cæsar's quarters. As he was already acquainted with such sights as he saw in the forum, he wearied of them and pushed his way down one of the streets. He had gone some distance when he found that he had passed out of the crowd and was in a part of the town where but few people were to be seen. He had barely realized this when from behind him he heard a scream and a clatter of hoofs. He whirled and saw a pair of maddened horses dashing down the street in his direction, while the chariot to which they were attached rattled wildly behind them. Boys yelled and dogs barked, and thus the animals' fright was increased.

Just as the young soldier was stepping aside to be well out of the way, he saw the face of a girl rise above 
the side of the chariot. She was making a wild effort to clutch the dragging reins. In a flash he saw that she was helpless and likely to be killed. Just at that

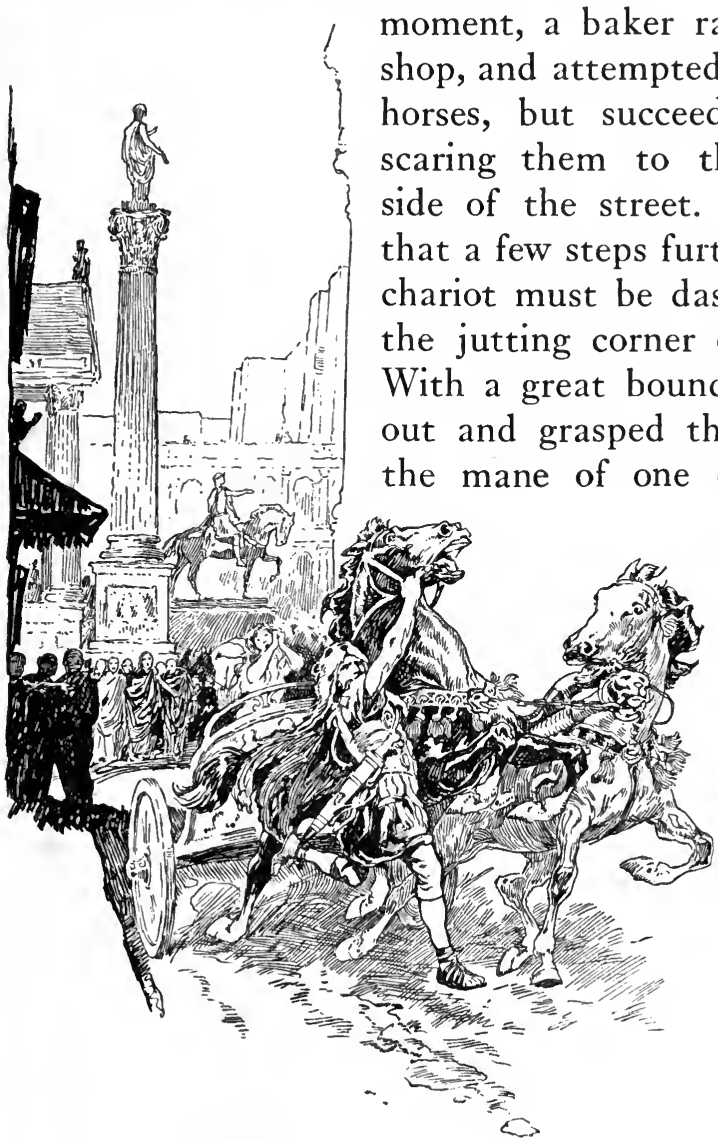


been in the chariot. She was rather tall, had brown eyes of wondrous luster, a tender mouth with full lips, glossy black hair, and a complexion of that transparent darkness which is lighter than any fairness. She seemed kind, yet her features and expression were withal haughty and dignified.

"The surgeon says you are only stunned a little and will be able to walk in a short time," she said. "My name is Trebonia. I am sure you saved my life. A crowd of rollicking, roistering, young patricians here from Rome stopped my chariot, and tried to kiss me. I begged them to let me go, but they would not. Before they knew what I was about, I slashed the horse and he dashed away and ran over one or two of them. But I got part of a bad bargain, for my driver fell out and dropped the reins on the ground. And that is how you came to save my life. I thank you, and my father will thank you, too."

"That is strange," said Caius. "Are young men allowed to loiter about the streets of Roman towns and attack women and girls in that manner?"

"Why, that is their most choice amusement," laughed the girl. "Even at Rome, the young nobles consider it fair sport to disguise themselves and go about the streets, especially at night, overturning the chairs of unarmed men, kissing the women, and sometimes even carrying them away.'

Just then Trebonius, the tribune whom he had met shortly before, entered the apartment.

"Welcome, my young soldier friend," he said. "I had no dream of so soon having the honor of entertaining you. I am also indebted to you for saving my 
daughter's life. I pray you will rest quietly at this house till you are recovered."

"I give you thanks, sir, but I can decide nothing until I see Cæsar. I fear it is already past the time at which I was to go to Cæsar's," replied Caius. "I must go at once."

"I shall be glad to send you to Cæsar," said Trebonius. It was so arranged, and as Caius passed out, he saw the girl in the atrium. And she smiled on the tall young soldier with something more than gratitude.

When he entered the room where Cæsar was, the Proconsul greeted him heartily. "How have you fared in Gaul since going into winter quarters?"

"I have been well, and I hope you have been also," replied Caius. "But I have just now had a hurt that has kept me from coming to you as soon as I ought. I beg your forgiveness for the delay."

"You are forgiven, Caius," said he. "I hope your hurt was not serious."

"Not at all serious," said Caius. "I am well even now. I was stunned and knocked senseless by a running horse. I was carried to the house of the tribune Trebonius, and he sent me here after my senses returned. I am quite over it."

"That is fortunate," returned Cæsar. "You are also fortunate to be here at this time. You may see something of the people and the customs of our great city, Rome. You may see senators, quæstors, prætors, knights, lictors, and what not. It is all very different from our camp life in Gaul. I have seen very little of the like myself for the past few years. By the way, Trebonius has a beautiful daughter. A marriage with 
her might be a wise thing, as the family is influential at Rome. Did you see her ?"

"I saw her, but I do not yet think of a marriage," replied Caius. "But I thank you for your thought of me."

"Well, perhaps you will see more of Trebonia," continued the Proconsul. "Her father is not now a tribune. But he loves power and appearance, and so keeps up the guise of a tribune. He will perhaps go to Gaul with me as a lieutenant."

Caius made no answer.

"Perhaps you would be interested to see Rome itself while you are so near it," Cæsar continued. "Or perhaps you would like to visit your mother."

Then a great longing came into the youth's heart, and the desire to go home shone clear on his face for a moment.

But he restrained his feelings, and answered: "No; I shall not go. My future lies in Gaul." 


\section{CHAPTER II}

THE STANDARD BEARER HAS A GOOD SUPPER

CAIUs was to wait two days at Luca to rest. On the night of the second day, Cæsar furnished a great feast for such Romans of note or importance as were in the town. Caius was bidden by Cæsar. "You may see something of the customs of the city," he said to the youth. "Besides, you may see Trebonia's bright eyes again."

Caius flushed, for the beauty of the girl had appealed to him, and, too, she had been kind when he was hurt. So he found himself eager to attend the feast.

When he arrived, he entered the great hall of the house. In the crowd gathered there, he saw Lanius talking with Trebonia, but she seemed anxious to leave him.

"Why, here is my rescuer," she cried when she saw Caius. She immediately turned away from Lanius to him. "I am so glad to see you. I feared you had gone back to fight those horrible Gauls. Come, Cæsar has promised that you shall recline at the feast with me. You shall tell me many stories of your heroic deeds."

She laughed with unfeigned gladness, and Caius followed her to the large hall in the second story of the house.

Cæsar had invited many guests, and, in order to have 
room, the tables had been placed about all sides of the apartment except one. Already many persons were in their places. Cæsar himself reclined at the head of the tables, and on the same couch with him

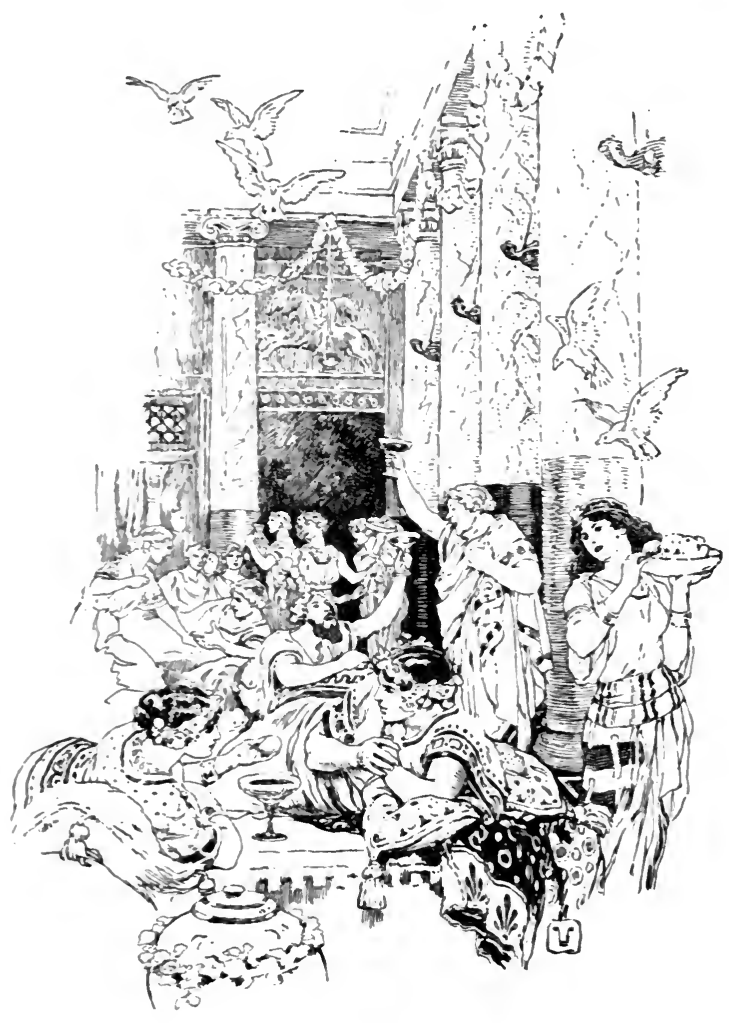

were Pompey and Crassus. A number of Roman senators and lesser dignitaries were present. Some of them had brought their wives and daughters with them from Rome. 
To the eyes of Caius, accustomed only to the rude camp and the army, the noble-looking men and the beautiful women, in the bright lights of the richly furnished room, seemed a picture of unsurpassable splendor. He was half bewildered, and scarcely knew what to do. But Trebonia, still talking, led him to the couch to which they had been appointed.

"Welcome, Caius," called Cæsar from his place. "This looks little enough like the meals we bolt in our tents in Gaul. Take your place with fair Trebonia, and may you feast with gladness, and forget the hardships of our camp life."

A quick glance at the Proconsul showed the young soldier the position he must take on the couch. He reclined at its head on the left side with his shoulders raised on his left arm and supported by great cushions of feathers. On the same couch, Trebonia reclined in such manner that her head was even with his breast, and her shoulders were also supported by cushions.

"Who is that slant-headed man over there on the other side of the room opposite us?" whispered Trebonia as they bathed their hands in the basins brought by a servant. "I do believe he is one of the ruffians who attacked my chariot yesterday."

"That is Lanius, one of Cæsar's followers in Gaul," answered Caius. "I saw you talk with him. I thought you knew him."

"I do not," she said. "He was speaking with me when you came, but I do not know him. He is an impudent man."

But now slaves were passing and placing on the head of each guest a garland of roses and lilies, and close 
behind them others followed, anointing their heads with sweet-smelling spikenard, while the soft strains of flutes floated into the room.

"Let us pray the gods, friends," said Cæsar. "It is not fit that we should forget the gods of our fathers." And he poured out a libation of rich Falernian wine on the tesselated floor, and called briefly on the gods of Rome to grant joy, protection, and guidance.

Meanwhile, the senator Colius, on a couch near to that of Caius and Trebonia, was muttering to himself. "Little it is that Cæsar believes in the old gods of Rome or any other gods but himself. I wish I could see which is to be the stronger, he or this Pompey who looks so solemn and great. I believe that Cæsar means to make Trebonius one of his lieutenants. I have asked for the same office."

But just then the libations and prayers were ended, silence ensued for a moment, and Cœlius was near to being left talking alone.

"He is very jealous of my father," whispered Trebonia, in explanation to Caius. "He now fears my father is to be given an office in Gaul which he desires for himself. That is well enough, but it is strange he can never learn that he cannot by any means ever be the equal of Trebonius."

The slaves now brought food. Eggs and sweetened wine were served, and all appetites were sharpened except those of Caius and Trebonia. They seemed pleased only when they looked into each other's eyes.

Then peacocks, pheasants, guinea hens, thrushes, and sausages were served in leisurely succession. Next, a great boar stuffed with a seasoned mixture 
of other meats and roasted whole, was brought in. The guests ate and drank and grew hilarious.

But Caius heard only snatches of the talk of Cæsar, Pompey, Crassus, and others of the senators and officials. He listened only to Trebonia, and forgot Gaul, and battles, and Cæsar, too, until she spoke of him.

"Your Proconsul, Cæsar, must be the greatest Roman alive," she said, after a time. "Why, the senate has decreed two great thanksgivings at Rome in honor of the victories he has won in Gaul. One of fifteen days, and one of twenty days. Such great honor was never voted any Roman before. But I was glad, for everybody forgave each other after the manner of thanksgiving times. Why, Crispilla, one of my friends who had a grudge against Publia for having brighter eyes than herself, forgave her the crime. And would you believe it? She even kissed her at one of the great festivals and continued her forgiveness for a full week after the thanksgiving was over. Don't you think that remarkable?"

"I do not know," answered Caius, awkwardly. "I know little of such things. Tell me more of the thanksgivings and what is done at Rome."

"I will if you wish it," she said. "But first I wish you would make your friend, or Cæsar's, that Lanius, leave off staring so hard at me. It frightens me."

Caius had been oblivious of the look of hate and envy Lanius was darting upon them, but now he perceived it. With a flush of long-repressed anger against him, Caius, forgetful of all else, started up with the halfformed intention of choking his enemy. But Trebonia pulled him back. 
"Come," she said. "I was only joking. Now see what you have done! You have upset a dish of your bread, and it has fallen on the floor."

"Sweep the floor here, slave," called Caius. "My bread has fallen on it.'

"No, no, you must not do that," cried Trebonia. "That would bring you ill luck, don't you know it? I will pick it up and place it on the table, and you must not brush those crumbs away, else you will offend the household deities."

Caius fumbled awkwardly, forgetful of all omens he had ever known.

"Come, get that savage frown off your face," she pleaded with mock severity. "I was only teasing. I do not wish that poor man who stares so to be killed. Anyway, he smiles and laughs, now. I believe he is not dangerous."

And Caius was enraged almost beyond endurance to see that Lanius smiled and talked with his companions, while they looked meaningly in his direction, evidently highly amused.

"Listen now," he heard Trebonia saying. "I will tell you of the great thanksgivings at Rome. The images of all the gods are crowned with garlands of the most beautiful flowers and their heads are anointed with richest perfumes. Their altars are wreathed with laurel, olive, and myrtle. All the temples are thrown open, and the prisons are emptied and the prisoners go free and glad. No work is done, every house in the city is thrown open, food and wine are given in plenty to all comers, law courts are closed, and all give thanks to the gods. Great bands of beautiful boys and 
THE STANDARD BEARER HAS A GOOD SUPPER I6I

maidens wreathed with flowers march and sing and dance in the streets. Oh! it is all so pretty and sweet. I wish you could see Rome at a thanksgiving. But I am sure you will, for, of course, you mean to come to Rome when Cæsar has his triumph. That is the greatest time. I have heard my mother tell of seeing triumphs. Will you not come then, Caius?"

"Yes, I will," said Caius, with emphasis. Influenced by the scene, the wine, Trebonia's eyes and beauty, the description she had given, he was ready to promise her anything. And thus she talked and smiled, and Caius looked and listened, and grew more and more forgetful of all else save Trebonia.

But now the slaves brought huge baskets of fruits.

"Oh, I am so sorry," cried Trebonia. "Here come the apples, and that is the last of the feast. We have gone from the egg to the apple. Be careful, now, and do not rise from the table till all have finished. That is a bad omen and might cause your departure from life. I will burn the bread you dropped in order to propitiate the gods of this household, so that you may not come by ill luck in that way."

The flute players now struck a more lively air, and the players and buffoons who had been busy during the meal endeavored to outdo all their previous efforts. But even now Caius and Trebonia were oblivious to the entertainments and could only talk and look at each other. At a signal from Cæsar, all rose from the table together, and began to pass from the room.

"Farewell, Caius," said the girl, in low pleading tones. "Won't you come to Rome, some time?"

"Yes, if you say for me to come, I will do so." 
"Come soon then," she said, and she was gone.

Left standing alone, forgetful of everything save.the girl and what she had said and looked, Caius was recalled to himself by a hand laid on his shoulder. "I do believe my little hint is being taken in earnest," said Cæsar. "Well, she is a beautiful girl, and she would give you influence at Rome if you claimed her as your wife. I shall ask Trebonius to become my lieutenant in Gaul, and perhaps you may see her again before long. But enough of that for the present. Take some rest now, for at daylight I wish you to be at my tent with your attendants, ready to set out on the return to Gaul with dispatches for Labienus."

As Caius passed along a dark and deserted street on his way to his lodging, two men sprang out upon him. But just at that moment a window above them was opened, letting out a dim light and a flood of slops from a barrel in the hands of the occupants of the house. He had barely braced himself, ready to fight, when his attackers were overwhelmed with the thick mass of ill-smelling stuff, so that though the light fell full upon them, they were so besmirched, that he could not clearly recognize either of them as they stumbled blindly away, snorting and blowing their noses and cursing their dirty luck.

"It is fortunate for me that the people of the city empty their house slops in the streets," he said. "But unfortunate that they poured it on so thick that I could not tell who were my friends."

Nevertheless, he had a shrewd guess that he knew who the two were.

In his quarters, he tried to rest. But as though the 
THE STANDARD BEARER HAS A GOOD SUPPER I63

vision of Trebonia lay in his eyes and was too delicious to close them upon, he slept not a wink. He rolled from side to side, recalling her every lightest smile, gesture, or word, living it all over and over again.

At the first light of the day, he set off to bear return dispatches to Labienus.

On reaching the winter quarters in Gaul, Caius was surprised to find Titus there. He had grown stouter and thicker than ever, and his face showed no sign of his temper having become any the milder.

"How come you here, Titus?" exclaimed Caius. "Have you left the sheep alone to be lost?"

"Do you think I intended to stay and watch your sheep all my days ?" said Titus, doggedly. "I mean to be a gladiator or a soldier. So here I am. My next brother, Marcus, is keeping your sheep. He is dumb, for a wolf once got the first look at him. But he can guard your sheep as well as I can keep them. Here is a letter for you."

Caius broke the seal and read, eagerly and hungrily:

Camilla to her son Caius:

I trust that you are well and happy. I and Simmias and Chloe are well. The sheep and olives have not prospered, but we have not suffered. Titus grew more and more restless and wanted to come to the army. Aid him to a place in the ranks if you can. His brother keeps our sheep. I shall hope to see you when you can well be spared. But I pray you will not let your love for me draw you away from the army in such a way that you may lose any opportunity to advance your own fortunes or to retrieve those of the family. "Come home with your shield or on 
it." Simmias and Chloe beg to be remembered. You know I love you with all my heart.

Fare thee well.

Trebonius came to the army in Gaul as Cæsar's lieutenant, and Trebonia came with him. Caius saw her often. And a whole winter had passed before he ceased to think of her, even when he looked at her beautiful face. For he had seen that she could be as kind to others, even to Lanius, as to himself. 


\section{CHAPTER III}

THE STANDARD BEARER HEARS OF A DISTANT LAND

Along a low sandy stretch of beach, facing the ocean, on a day in the late summer of the fourth year of Cæsar's proconsulship in Gaul, there stood in groups, or

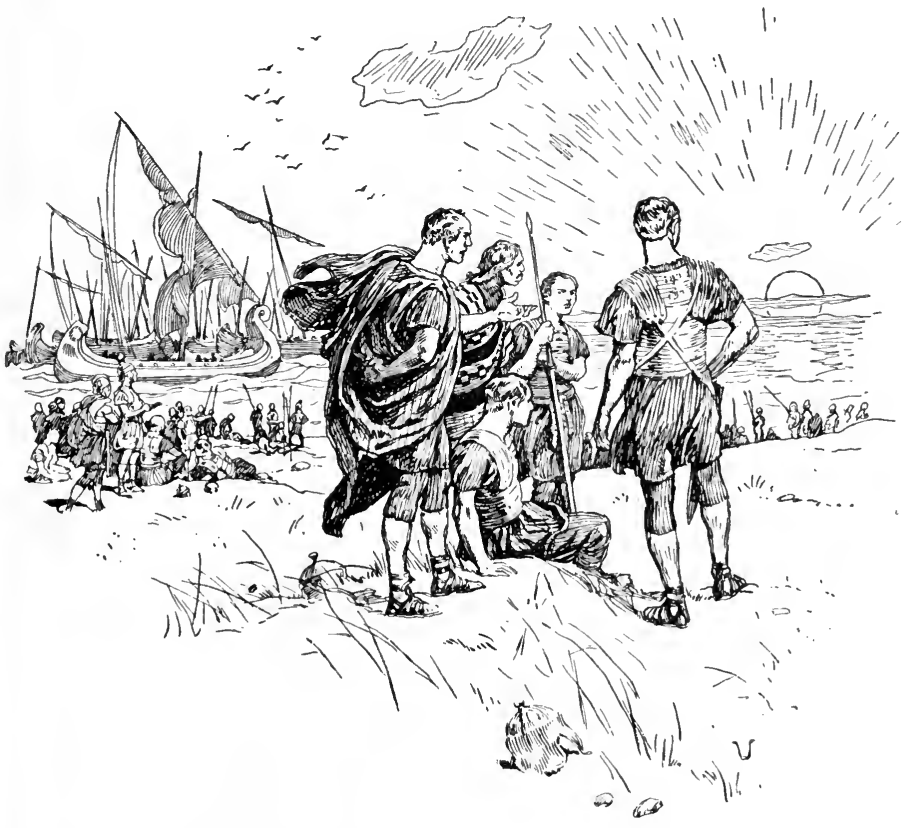

paced singly, numbers of legionaries, centurions, standard bearers, tribunes, lieutenants, and other officers of the Proconsul's army. A stiff breeze flapped and 
fluttered the loose folds of their togas and the crests of their helmets out to seaward. At the distance of an arrow's flight, on the high, white-crested waves, rode a Roman fleet of war vessels, extending for more than a mile along the shore, in well-ordered rank and file. The sun was just dropping behind the waves of this Great Western Sea and tingeing with colors of the rainbow the sandy beach, the crashing surf, the fleet, and a bank of low-lying clouds to the northward. On the land side, upon the flank of a hill sloping seaward, stood the friendly ramparts of a strongly entrenched camp in which lay the Roman army.

In one of the groups on the beach, stood Baculus, Sannio, Titus, Caius, old Matho, the merchant, and two or three others more or less bound to them by ties of friendship.

"I am glad all the baggage is loaded upon those water traps, though I like not the thought of sea travel, and much less do I like the idea of sea fighting," said Baculus, glancing out toward the triremes rising and falling roughly with the roll of the surf. "I like least of all this voyage to Britain," he grumbled. "I have always heard that it is a land of fierce savages, and they do say that it is clear away on the edge of the world, where one may drop off and fall down, down, down to nowhere."

"I have always heard that it is near the land of the Hyperboreans," said Sannio, "and if that be true, I have a fear that booty will be scarce, even though we should conquer them all. Besides, Coprax, my Gallic slave, told me that his father had once gone to Britain with a Gallic army. The Britains had many Druids 
and magicians with them to aid. Just as the Gauls were ready to land their boats, a great British magician clad all in white came out from the myriads of British warriors on the beach, and with raised hands uttered a charm, and the whole island of Britain began to shrink and become less and less till it was no bigger than a shield. At the same time a great wind sprang up and drove the Gallic ships far past the island into a great waste of water where were only waves and big rocks."

"Oh," said Baculus, "do leave off your nonsense. Who believes such stories? Why don't you go and tell Cæsar and get him to give up the voyage?"

"Tell Cæsar!" exclaimed Sannio. "No use to tell him. He believes not even in Jupiter, though he does sacrifice to the gods. But Sannio believes. I grew up on a farm in the country and saw many magicians in Italy when I was but a boy. One night my friend and I saw two haggard old women who dealt in magic creep into a cemetery when the moon was new. They came barefooted, with their robes tucked up, and hair flying loose in the wind. They began to pick up toe and knuckle bones, and to pluck poisonous herbs. Then with their long black nails they clawed a hole in the ground and tore a black lamb in pieces with their ugly teeth, while they uttered a charm in their squeaky voices, and the blood from the lamb flowed into the hole. Then the manes and the shades of the dead, with chattering cries and gibbering words, gathered around the women, and the noise was so awful we ran away in terror."

"I think these stories are all wrong," said the old merchant. "Men have been wont in all ages to garb 
the unknown in fantastic forms. I have never been in Britain, but Hanno, the Phœnician, whom I see every year when he comes to Rome to sell the tin he buys in Britain, told me he had found them to be, indeed, savage people, huge in form, fierce in manner, and wearing scant clothing of skins, but otherwise not greatly different from these Gauls. He said that they tattoo themselves and paint strange figures on their bodies with a blue paint."

"At any rate, I do not like water fighting and unknown dangers," persisted Baculus. "You all know I love a tough fight with a bold enemy on land, one that I can see face to face, and my body bears proof of it, but this adventure! Bah! Just look yonder where those cliffs come down to the sea! Those huge white waves are beating up their sides higher than Caius could reach with the staff of his eagle. I wonder such waves have not already sunk these ships. I wonder more that Cæsar should undertake such a chase after pearls. That is what they say he is after in Britain. All the pearls might turn to pebbles for what I care."

"Well, Cæsar has determined upon this voyage, and so there!" said Sannio. "He is not likely to make any change to suit the judgment of the centurion, Publius Sextius Baculus, or the beliefs of Sannio. As for me, if any pearls are to be had in Britain, I hope a few may fall to my lot. They sell well at Rome. But I am afraid there is not a pearl in the whole land. It is the common talk among the soldiers that Cæsar is going to Britain because the people there have helped the Gauls, and he thinks it needful to conquer Britain in order to keep Gaul conquered." 
Caius and Titus as younger men and subordinate officers said nothing, but each thought, not without dread, of the stories they had heard about the camp concerning this land lying beyond the limits of the known world, probably containing dangers and terrors which even the Roman might fear without shame.

"Well, it is time we slept," said Baculus. "We embark an hour after midnight." And so saying he set out toward the camp, followed by several of the others. 


\section{CHAPTER IV}

\section{THE STANDARD BEARER REFUSES TO WRITE HIS NAME}

CaIUs walked away toward a Gallic hut a half mile up the shore to buy a choice fowl which he wished to present to Cæsar to be used as a victim for sacrifice. As he walked, his mind dwelt on the stories he had been hearing about Britain. These did not tend to make him especially comfortable, though he was too stout-hearted and proud to admit that he felt any fear. Now, as the moon had not yet risen, it had grown very dark, and he soon lost his way and was wandering in the marshes and thickets, he knew not how far from the shore. He stopped and listened. All was still.

He must have wandered farther away than he knew. He shouted with all his might, hoping to get an answer from some soldier or sailor of the fleet. But he heard no sound save the echo of his own voice among the thickets, the solemn croaking of frogs, and the dismal cries of the night birds as they whirred and fluttered among the trees. He almost expected to see a faun or a drove of ugly lemures start up from the ground, and he saw in imagination the witches of Sannio. Then he fancied that some unknown danger, real and tangible, lurked near, and he thought he heard twigs snap here and there as though stealthily trod upon. He was beginning 
to feel that unreasoning terror that paralyzes and maddens a man when he is lost and knows that he is lost. At the next instant it seemed that his blood froze and his hair stood on end, and he shouted again and again in a frenzy of desperation.

"Hold, my pet, you are not quite alone!" And he felt himself suddenly seized by strong hands, jerked

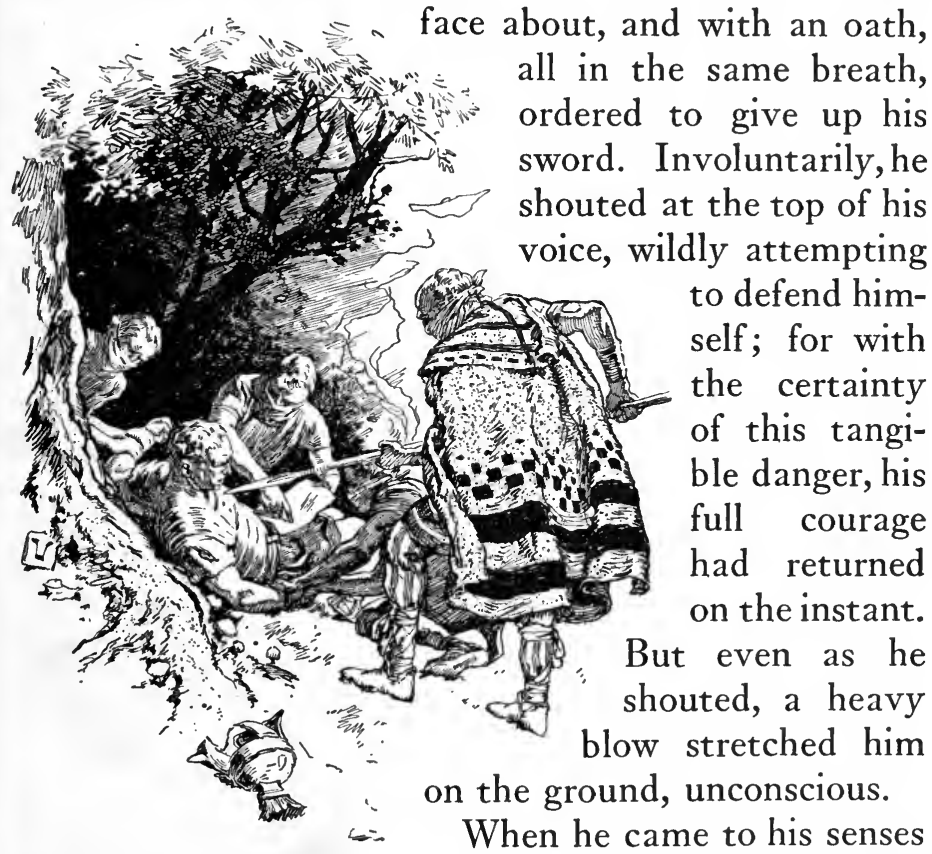
after what seemed an age, he found himself surrounded by three or four men with masks over their faces. A light made from dry twigs popped and crackled, enabling him to see them only dimly.

"Here, come now, you brave soldier, aquilifer, and pet of Cæsar, write your name quickly on this bit of 
papyrus and we will let you go unhurt," said a voice which seemed peculiarly familiar in spite of its attempted disguise.

Dazed as he was, he knew that here was some trick and that he ought not to write his name on the paper.

"Sign it," hissed another, giving him a cuff on his jaw and thrusting a stylus into his hand.

As Caius had been disarmed, realizing his helplessness, and knowing full well that he was in the hands of a set of ruffians who would but have the more reason to murder him after forcing him to do their will, he still remained silent. Then it occurred to him to read the paper, but his glance scarcely fell on it before they began to swear and strike him, giving him no opportunity to read.

"It is but your business to sign it," said one of the men. "We will attend to the reading our worthy selves. Sign it at once or we cut your throat."

But Caius now sprang up from where he lay on the ground, hurling two of them sprawling in the mud of the marsh. Then he seized one of the swords which they had dropped and quickly braced his back against a great oak and stood glaring upon his captors.

"Come, now, be reasonable," said one who seemed to be their leader, in accents somewhat Gallic. "We mean you no harm. Only put your name on this paper, and we will be gone."

"Perhaps, I might, if it would help you and not harm me. But I do not know what your paper is."

The leader continued to urge him, and Caius stood on guard. Meanwhile, one of them had crawled behind the tree and now sprang out and caught his sword arm. 
The others were upon him at once, brandishing their swords at his throat and threatening.

"Will you do our pleasure now ?" they asked.

"No," he roared, "I will not."

"Then we shall take you further into the forest and hack your head off," said the leader. And they all pressed upon him and began to drag him away, despite his desperate struggle to prevent them.

He began to think he was in his last extremes, when, with a shout, Titus, Baculus, and Sannio sprang in upon his captors. The latter did not stay to fight, but scurried away into the thickets.

"By Hercules! But how came you off here in these marshes alone?" asked Baculus. "If you hadn't yelled so loudly a little while ago, we shouldn't have found you, for we were just turning to go back to camp."

"I was going to the Gaul's house up the beach and lost my way," replied Caius. "I was sure those friends of mine were going to kill me. I had given up all hope. But how come you here?"

"Why, Titus there saw you go away, but thought nothing of it till you failed to return to the tent as usual. Then, when we remembered that he had seen three or four strange men pass near us on the beach, watching us covertly, and when he recalled that they had later followed in the direction taken by you, he grew uneasy. He told us, and we hurried neck and limb to find you."

As they turned away toward the camp, Caius saw lying on the ground a piece of papyrus and picked it up and thrust it into his belt. He would read it when he 
had a light. They hurried away to snatch a little sleep before the labor of embarking.

They were admitted to the camp by the guard.

"Our centurions are out late to-night," said one of the men, evidently an acquaintance of Baculus. "How many natives did you rob ?"

"Keep to your own stand and spear," grunted Baculus.

"Well, who were the men that just passed in ahead of you ?" asked the same man.

"I don't know," replied Baculus, carelessly.

But Caius wondered. They passed on. In one of the tents was a loud snoring.

"That fellow sleeps hard," said Titus.

"I don't know," said Sannio. "He may be asleep with his eyes, but his nose is wide awake."

Caius knew that this was the tent of Lanius, and, listening carefully, he knew that some one within was only feigning sleep. 


\section{CHAPTER V}

\section{THE STANDARD BEARER LEADS THE LEGIONS}

THE order to take ship sounded about midnight. To the disgust of Baculus, despite his protestations that he did not want to go to Britain, by a sudden change in Cæsar's plans, the Twelfth legion was left to guard the port. Only the older legions were carried. Immediately upon the signal, the camp was astir, orders were shouted, trumpets rang, men hurried down to the water's edge, boats went and came, and in less than an hour the blare of the tuba called from end to end of the fleet. The oars rattled in their sockets, the ropes creaked, the sails flapped in the wind, and the fleet swept out toward the chalk cliffs of Britain - the first naval fleet of civilized men to seek those shores.

By nine o'clock in the morning, through the misty light, the Romans on the lookout saw the land bulging high and steep before them. As the fleet drew nearer, the legionaries saw, gathered on the high headlands, thousands of long-haired, blue-painted Britons watching their approach in silence, but with weapons in their hands.

Seeing that the Britons might easily hurl javelins and stones from the heights upon his legionaries, should he attempt to land at this point, Cæsar turned his fleet up the coast to find a more suitable place for disembarking. But the Britons appeared to be aware of his intentions, for they followed on the land with such 
speed as to keep pace with the vessels, ready to oppose his landing on their shores wherever he might make the attempt.

When the fleet had proceeded up the coast for some seven miles, a long stretch of low flat shore was sighted, and here the ships lay to and Cæsar gave orders for disembarking.

The Britons now hurried down close to the water's edge and fairly swarmed for the distance of a mile or more along the sands, their red heads, long mustaches, and huge bodies, blue painted, and armed with huge javelins, long swords, and knotted clubs, all showing wild, fierce, and defiant, against the grassy shores and the great forests of ancient oaks and beeches. Their long-bearded priests, with loosened hair and flowing robes, hurried hither and thither among them, urging them with hideous shouts to fight bravely and not to give over their lands to the stranger.

The Romans were dismayed at so savage a scene, and so, when the order to disembark was given, only a few of the soldiers ventured to leap into the waves. Some of these, overcome by the wash of the surf, fell in the water, and being unable to rise again on account of the weight of their armor and the force of the waves, were lost. Such as maintained their footing were soon surrounded and killed by the Britons. The latter then retreated to the shore to await the next move of the Romans.

Caius and Titus stood together on the deck of one of the triremes. "What horrid barbarians!" exclaimed Caius. "Look yonder at that big, red-hearded giant with the knotted club. I believe he is preparing 
to hurl it upon us." And even as Caius spoke, the Briton swung his great knotted club and let it drive. It fairly groaned as it hurtled through the air, and barely missing Caius, struck the shield of a legionary just behind him, knocking the soldier sprawling. And then hundreds of them threw a shower of stones which rattled and glanced on the Roman armor.

"It seems that we are going to be beaten back and not allowed to land," said Caius.

Hardly had Caius spoken when a shower of stones and heavy darts from the ballista on the engine ships sang and fell rattling among the barbarians, killing a number, but doing more harm to them by the surprise and fear created. The barbarians at once fell back further up the shore. But still the Roman soldiers hesitated to leave the ships and to plunge into the rolling surf.

"Now is our time to win glory!" exclaimed Caius. Then he leaped upon a pile of shields and called out, "O Gods of the Romans, who have ever favored us in battle, grant now that what I am about to do may be for the glory and welfare of the Roman people." Then he sprang upon a weapon case so he could be seen, and holding the shining golden eagle aloft, shouted aloud, "Fellow soldiers, leap forth now unless you are willing to betray your eagle to the enemy. I, at least, shall do my duty to the state and to my commander." At the same moment, holding the eagle on high with his left hand and drawing his sword with his right, he leaped upon the railing and thence into the water, closely followed by Titus. At once, throughout the ship rose a clamor of voices. "Save the eagle!" 
"Follow the eagle!" "The eagle will be lost unless we follow!" "We are disgraced if the eagle is lost!" There was a mad scramble for the sides of the ship. Over the soldiers climbed, and right into the water, some falling with the weight of their armor, others being dashed down by the force of the swelling waves, and still others slipping into deep water from which they never rose. But the greater part maintained a footing and pressed after the standard bearer toward the shore. The soldiers of the other legions seeing those of the Tenth advancing, followed their example, and soon the whole of the two legions were moving toward the beach.

Caius still led the way, though now he was attacked by two Britons who had somewhat recovered from their surprise at the missiles from the ballista. The huge barbarian whom he had noted from the deck of the ship struck at him with his sword, but the weapon, being of bronze, bent on the well-tempered steel of Caius's sword with which he parried, and Titus stabbed him. The other Caius cut down. Still others pressed upon them and still they cut and hewed, and the water grew thick with foam and bright red blood and floating bodies. Caius did not know the whereabouts of the chief centurion, and scarcely any man was at his own standard.

But all pressed shoreward, a line a mile long, up and down the shore. Every foot of the advance was stoutly contested by the islanders, and whenever a Roman became by any chance separated from the mass, he was at once surrounded by British horsemen and killed. When at last the Roman line stood on the shore, an 
onset. was made against the Britons and they were easily forced back. But hardly had the Roman lines come to a halt for breath before the cry arose among them, "The chariots! The chariots!" and even at the instant the long line of chariots drawn by the wiry little British ponies, their heavy wooden wheels rattling and knocking, came charging at mad speed upon them. The Roman ranks opened to let them pass through, but contrary to expectation, just as the chariots had nearly reached the Roman lines the horses were suddenly stopped, the sword men in them leaped out and charged upon the Romans, the drivers rushed out upon the poles of the chariots and stood upon the yokes, striking downward, thus killing and wounding many Romans.

One of the chariots bore down upon the point where Caius and Titus stood. "Stand still till they are near us, Titus," said Caius, "and then run quickly to one side." At the instant the horses were upon them, Caius with the eagle darted aside to escape, but Titus leaped up and clung to the bridle of one of the horses and cut the animal's throat, thus stopping the chariot. A swordsman and the driver quickly leaped from the pole of the vehicle and charged upon Titus, who fended with his shield and struck out stoutly with his sword. The two together were on the point of beating him to the ground when Caius stabbed the other horse, which reared and in coming down struck the shield of Titus with its fore foot and knocked it from his arm. Caius rushed to his assistance, whereupon one of the Britons snatched up the shield, and the two ran away. 
A glance along the Roman line showed Romans everywhere breaking from the ranks and rushing out to stab the horses. Thus the charge was checked and the Britons fled. The Romans began to pursue. But the order to halt was sounded, for Cæsar did not wish to risk his legions in the forests among unknown dangers from the enemy.

Soon he came along the lines, cheering the men and praising them for their bravery. As he came near Caius and Titus, he stopped. "And how fared the eagle of the Tenth, young Caius ?" he asked.

The chief centurion of the legion had now come up and he hastened to tell the story of Caius and the eagle to the Imperator.

"Grand!" he cried when he had heard it. "I shall see that you are rewarded. But how come you without your shield, my sturdy Titus ?"

Titus threw himself at the Imperator's feet and in a burst of grief acknowledged that he had lost it, a deed the most disgraceful a Roman soldier might be guilty of.

"He lost it in defending the eagle," said Caius, "and no man could have done better." And Caius briefly told the story.

"You shall have one of the best shields in the army, and you are to take the place of a centurion to-morrow," said Cæsar. And giving special orders to the lieutenant relative to Titus, he passed on.

Thus was Titus made a centurion in the Roman army. And for once in his life did his stolid face break with smiles of joy. 


\section{CHAPTER VI}

\section{THE STANDARD BEARER HEARS A TALE}

Some months later, on the high banks of the Rhine, just below the point where that great stream and the Moselle mingle their waters and thence roll downward to the boisterous North Sea, Caius and Titus sat, watching the unusual scene of activity. From out the thick forests, team after team of the great Gallic oxen were driven, drawing huge tree stems and dropping them near the water's edge and winding away into the woods again to bring yet others. Thousands of Roman soldiers, all arms and armor laid aside, hurried here and there, everywhere, busy as a hill of antș. Here a group hewed the timbers into required forms, others rolled them into the water of the river, and still others with boats and poles pushed them to where they were needed, all working at the command of the fabri. Huge derricks, turning slowly with many a creak and groan, swung heavy timbers with sharpened ends into place, where they were propped for a moment, and then the weight of the ponderous pile drivers fell with loud thuds, time after time, until the timbers were driven firmly into place and men made them fast with nails and clamps of wrought iron as thick as a legionary's thumb. And so span after span of Cæsar's famous bridge across the Rhine was builded. On the banks of the river at regular intervals, their armor glittering in the rays of the sun, stood cohorts of soldiers, keeping guard while the others built the bridge. 
"It is now the morning of the tenth day since Cæsar ordered old Cornelius Balbus to begin the bridge,"

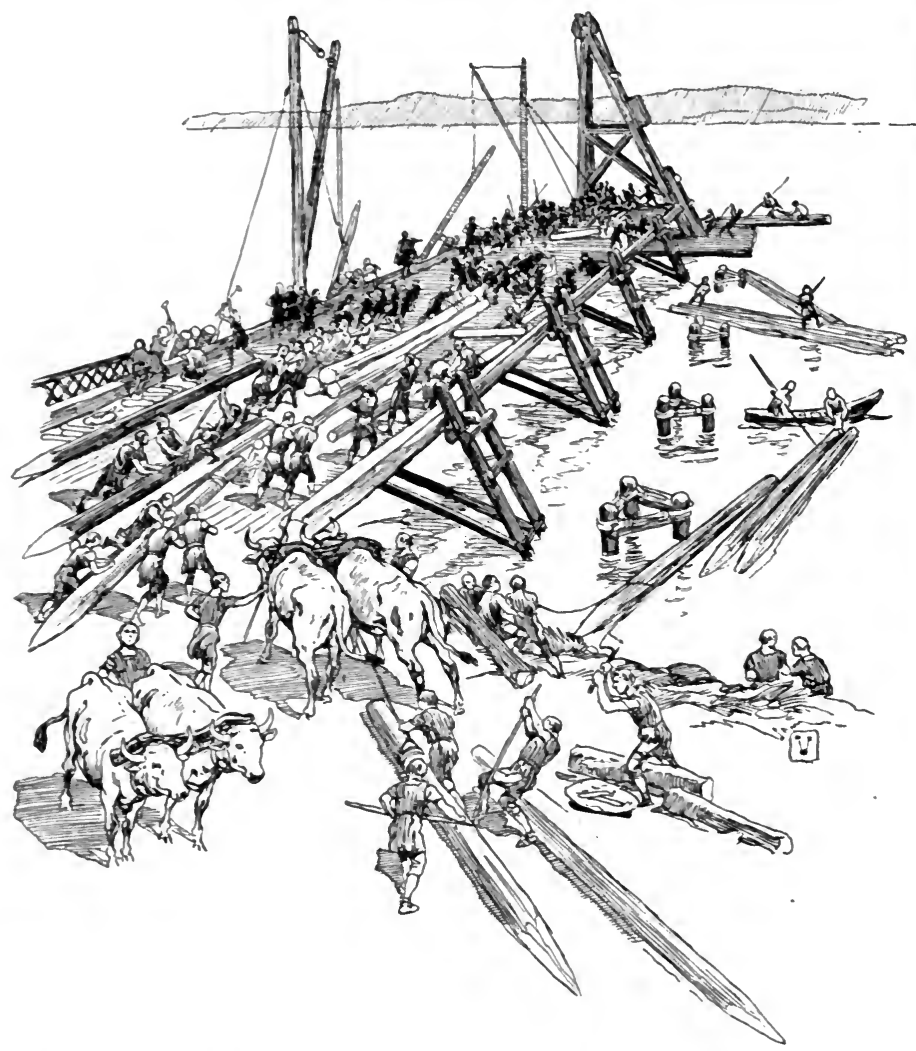

said Caius, lazily watching the work. "It looks as though the old smith would have it finished to-day. He can hurry men when a bridge or a fortification is to be built for Cæsar."

"I hope he will make these men finish to-day," muttered Titus. "To-morrow it will be my turn to 
work again if it is not finished to-day. I have worked on the bridge every third day and stood guard every third day with only a day to rest till I am tired of it. I came to Gaul to fight, anyway."

"Well, suppose there were fewer soldiers so that you had to work every day," laughed Caius. "As it is, Cæsar has enough men in the legions that he can give us one day out of every three to work, one to stand guard, and one to rest."

"If there had been so few soldiers as that we should not have worked at all, for Cæsar would not then have built the bridge to go into Germany," returned Titus.

"Your words show how little you have learned of Cæsar's ways," said Caius. "Why, when we first came to Gaul, he built a wall nineteen miles long with only one legion. The bigger the task, the more determined he is."

"Well, what is Cæsar going into Germany for?" suddenly blurted Titus. "Has the fighting given out in Gaul ?"

"I do not know exactly," said Caius. "But I learn from Procillus and Baculus that Cæsar is marching into Germany, chiefly on account of the Usipites and Tencteri, two large tribes of Germans. Three years ago in a war with the Suebians, the latter drove them out of their own lands, and ever since then the Usipites and Tencteri have been wandering about in Germany, with their wives, children, and wagons. Lately they were hard pressed by the Suebians again, and so they crossed into Gaul and destroyed the whole nation of the Menapians. Cæsar now fears, so Procillus told me, that these people may unite with 
the Gauls, send for other tribes of the Germans, and all together make him trouble. So he intends to show the Germans his power. I suppose you have not forgotten in these few days how we attacked the Usipites and Tencteri in their camp among their wagons and drove most of them into the Rhine - what we did not kill outright or take prisoners?"

"No, I have not forgotten, since I have by that battle become rich enough to put a band of gold about my sword sheath and to have a German servant," smiled Titus. "But I do not see why Cæsar needs to have us do all this work. Why could we not have gone over in the Gallic boats?"

"Oh, you ignorant rustic," mocked Caius. "Why not go over in boats? Well, it is not safe. Then again it would not be in accordance with the ideas of Cæsar and the Roman people to go paddling across into so great and unknown a country in Gallic skiffs. The Roman army must march across on a well-built bridge, in regular ranks, and steady order."

"Well, the fabri are hurrying the men to-day with more haste than before," said Titus, yawning. "I hope they do finish to-day."

Old Matho now joined them. "I hope this bridge will soon be finished, too," he said. "I hope to make some good gain in Germany. But not for the Germans. They never buy, but always sell. I have a large stock of such goods as Cæsar's legionaries pay well for in these wilds."

Before either of the youths could reply, a heavy crash of timbers and a loud splash of water drew their eyes to the bridge. One section of it had fallen in, 
carrying timbers, scaffolding, men, and all into the river. The water was covered with floating timbers and the bodies of men, some dead, others wounded, and a few swimming unhurt.

"By Libra and Pluto!" exclaimed Matho, "that thing has happened more than once in these last ten days. I wonder that the men do not mutiny and refuse to work at it any longer."

"Cæsar's soldiers never mutiny," said Caius.

"At any rate it is a dreadful sight," said the old merchant, "and I never hear such a sound but I smell blood, and I think of a venture I once had among the Nervians."

As the soldiers on duty were already rescuing such men as were unhurt as well as the wounded, the youths again lay on the ground and begged the old merchant to stay with them and tell them his story.

For a wonder he consented.

"Once some years ago I was trading in Farther Gaul, and gradually traveled northward.. Finally, I wandered into the territory of the Nervians. Few if any Roman traders had ever traveled among the people. They are a bold and hardy race, despising all foreigners and foreign customs. They believe that wine and soft clothing and such other goods as traders bring among them destroy their courage and soften their hardihood. After I had been in their country for a day or two, though I received no injury - nor trade - still I saw that I was regarded with suspicion and dislike. Then came a messenger from the king to order me to depart from his boundaries.

"I hastily set forth, hoping to pass from his country 
before the end of the day. But as night came on, the heavens suddenly blackened, the thunder rolled, lightning played among the huge trees, and great sheets of rain driven by hard gusts of wind almost swept me away. A storm was raging. As I was alone and no shelter to be had, I urged my oxen onward.

"A great flash of lightning seemed to set the blackness of the forest on fire. For a moment there was a horrific, splitting, tearing roar, and then I knew no more. All was blank as though I were dead. When my senses returned, I was lying on soft skins in a Nervian house with two or three of the Nervians about me. Among them was a fair young girl about twelve years old - just the age of my own little Nigra at Rome - who seemed specially eager for my welfare. I soon knew that I was in the house of King Boduagnotus himself, for I recognized the girl as his little daughter Bridiga. The previous day I had given her a Roman doll and a ribbon of purple silk. They cost me fifty good silver sesterces.

"As I lay and bemoaned the loss of my goods and feared what the people might do with me, the girl tried to comfort me. She told me I was safe and would be cared for. She said that a party of her father's warriors had found me under a heavy limb which had been torn from a great oak by the lightning. I had likely been dead, but the soft mud in which the limb had bound me had yielded under the weight. The men had brought me to the king, and she had begged him to take care of me till I should be well again.

"My leg was broken, and I lay long before I could stir from the house. All the time the little Bridiga 
tended me with the greatest care. I had a Roman book, the beautiful poems of Livius Andronicus. I read to pass a part of the time. She was curious and wished to know more about it. Soon I taught her to read it and also to speak Latin. She was very eager to learn and did so rapidly.

"Meanwhile, I knew the king was eager for me to be gone, and only endured my presence out of hospitality and for the sake of the golden-haired girl. Hospitality is one of the most marked traits of Gallic character, and hence I would have been safe, at any rate.

"At last I was well enough to travel, and I came away with no hurt. The little Bridiga wept and begged me to stay. I have often thought of her. I wish I knew if she lived and fared well after Cæsar defeated her father in that awful slaughter at the Sabis.

"But I had lost all my wealth, for robbers or some one had plundered me before the king's men found me. I have been busy since in trying to restore my fortune. May the gods favor me on this trip. I must go now and see if I can find some hungry legionary who wants to buy from me."

And he went away, leaving Titus asleep, and Caius thinking of the Nervian maid and a great deal more curious about the matter than he cared to own. What if this were the Nervian maiden whom he had taken for a boy? What if she were not the same? Anyway, what difference could it make to him, a Roman soldier of patrician birth, with a fortune to win and many wrongs to avenge?

He lay, for a long time, alone on the grass and tried to think of duty. 


\section{CHAPTER VII}

THE STANDARD BEARER PREPARES FOR A HUNT

CÆsAR's bridge across the Rhine was completed on the tenth day from that on which he had begun it.

On the next morning when the first light shone, the trumpets sang throughout the great Roman camp, the white flag on Cæsar's tent was taken down in token that the soldiers should strike their tents, the baggage was packed, the legions fell into column of advance, the trumpets again set the echoes flying on the river and throughout the forest, and the Roman army began to cross the bridge.

The rising sun tipped the steel points of the Tenth legion with silver as it led the way. The water of the swift, turbulent river splashed and gurgled uproariously as it dashed among the piles that obstructed its way. Occasionally, a huge tree or log brought down by the waters came rushing along with such force that it seemed the supports of the bridge must be broken away. Legion after legion now marched forth and across, a line a mile in length, reaching from the camp on across the bridge to the further edge of the open land, where, one after another, they were swallowed up in the dark shadows of the German forest.

After several days' march through the fire-wasted land which the Germans themselves had devastated to prevent, as far as possible, the advance of an enemy, the Roman army finally encamped not far from the Hercynian forest. 
There was a large number of Gauls in the camp who had followed the army into Germany. Many stories they told the Romans of the wonderful men of Germany, of its great swamps, and of its strange animals.

"Why do these Germans burn and destroy such fine crops and so many towns which might furnish at least some plunder?" asked Sannio of Crixus, a Gaul.

"Because," replied he, "that is their custom. Each German nation prides itself on the greatest width of territory it can keep devastated about its own borders. Then if an enemy threatens them, that they fear as they now do Cæsar's army, they will destroy their own houses, towns, and crops, and move farther on."

"I don't wonder that they move farther on in these dark forests," said Sannio. "I am sure they are full of fauns and wood sprites and magic as well as of wild beasts. They say this forest is the largest in Germany.’"

"It is the largest in the world," said the Gaul. "It begins at the borders of the Helvetians and Rauracians and runs along the Danube River to the territories of the Dacians. Then it extends round about many nations and rivers. It takes a man swift as the wind to walk around it in sixty days or more. In it the trees are so thick grown the shadows are black as night, and some of the trees reach to the clouds. No man goes in it or around it."

"How, then, does any one know all these things?" asked Titus. He was inclined to be rather skeptical. "Oh, well!" replied the Gaul, impatiently, "that is what they say. I was only telling you what I have heard." 
"I see," said Titus. "You are telling what you have heard as something you know. I have noticed many Gauls doing the like."

"By Bel, the bright sun god," exclaimed the Gaul, hotly. "If you tell me I speak falsely, I can prove on your body that I speak the truth." And his hand worked neryously over the hilt of his sword, while his jaws set and his eyes grew hard and bright.

"I'm ready," said Titus, stolidly, while drawing his sword. "I want all the practice I can get." The two were just ready to come to blows, when Cæsar, accompanied by several of his friends, passing that way, stopped and interposed.

Cæsar, learning what the discussion was about, grew interested, and then commanded the Gaul to tell more of the great forest.

"I know many things of it," he said, "but this man must not talk to me as he does."

"I will be surety that you are not interrupted again," said Cæsar. "Tell us something of the animals in the forest."

"Are there animals that yield beautiful and merchantable furs?" ventured Matho.

"I do not know that," replied the Gaul. "But the animals are the most wonderful and strange in the world. There is a kind of cow like a stag in form. In the middle of its head, between its ears, it has a single long straight horn which branches at the top like a tree."

A murmur of wonder ran around the group, but, encouraged by the attention Cæsar was giving him, Crixus continued. "Then there is the elk. It looks like a goat in shape and in the different colors of the 
THE STANDARD BEARER PREPARES FOR A HUNT I9I

skin, but it is smaller than a goat. Its horns are pronged, but they are bent every way like a broken bush. Its legs have no joints and it never lies down, not even to sleep. Should one by accident be thrown down, it is unable to rise again because of its stiff legs. To sleep they lean against trees. The Germans take them by cutting the trees almost down where they sleep, or by digging them at the roots till they will easily fall. The elks lean against them and both fall together."

"That is a wonderful animal," said Cæsar. "I should like to see one of them."

Thus further encouraged, the Gaul continued. "The aurochs is the biggest beast in the world. You could not reach to the top of its back with a Roman javelin. They are shaped and colored like a bull. They are strong and fierce and spare neither man nor beast, and can only be taken in deep pits digged and covered over with tree tops. The German youth prove their manhood by taking an aurochs. They must bring the horns and show them in public. Then they receive great praise. You cannot tame one even when it is very young."

"How did you learn these things?" asked Cæsar. "I was once made a prisoner by the Germans," said Crixus. "I escaped, and learned of them while wandering in the forests to hide from the Germans."

"Those are most wonderful animals," said Cæsar. "I should like to see them. Since we are to delay here for several days, we may hunt some of them. Let Caius, Baculus, Sannio, and this Gaul who knows of these animals advance into the forests this afternoon 
with fifty men and dig pits for aurochs and select trees for the taking of the stiff-legged elk. Then, early tomorrow we will go on a hunt. It were well sometimes to forget our battles and amuse ourselves with sports."

Cæsar and his companions walked on. "By Bacchus, but I do not want to go into this forest," said Sannio. "I see little profit in it, and I fear the fauns, the witches, and the magic of the place more than I do the animals." And he shuddered despite the fact that his hand rested on the hilt of his good sword.

"Yes, and so do I," said Titus. "I believe that there are magic and witchery in this great black forest much more than I believe there are such animals there as that Gaul told us about."’

Crixus had left the group, and there was no contradiction.

Caius and the party, sent to make ready for the hunt, found the reports of the great trees and the thick growth and grassy marshes, and of the darkness of the shadows, not by any means overtold. The darkness and the gloom were enough to lead wiser men than these to feel a dread of some unknown danger which might lurk in the bogs, the thickets, or the brakes, and which might be encountered in almost any shape of witchery or magic.

The party advanced cautiously, and at last found a place where, on a slight ridge covered with a growth of small trees, they found many tracks of some small cloven-footed animal. The Gaul said they were the tracks of the elk. So they carefully cut many of the trees near the ground till they were almost ready to fall. Some distance beyond they found fresh tracks like 


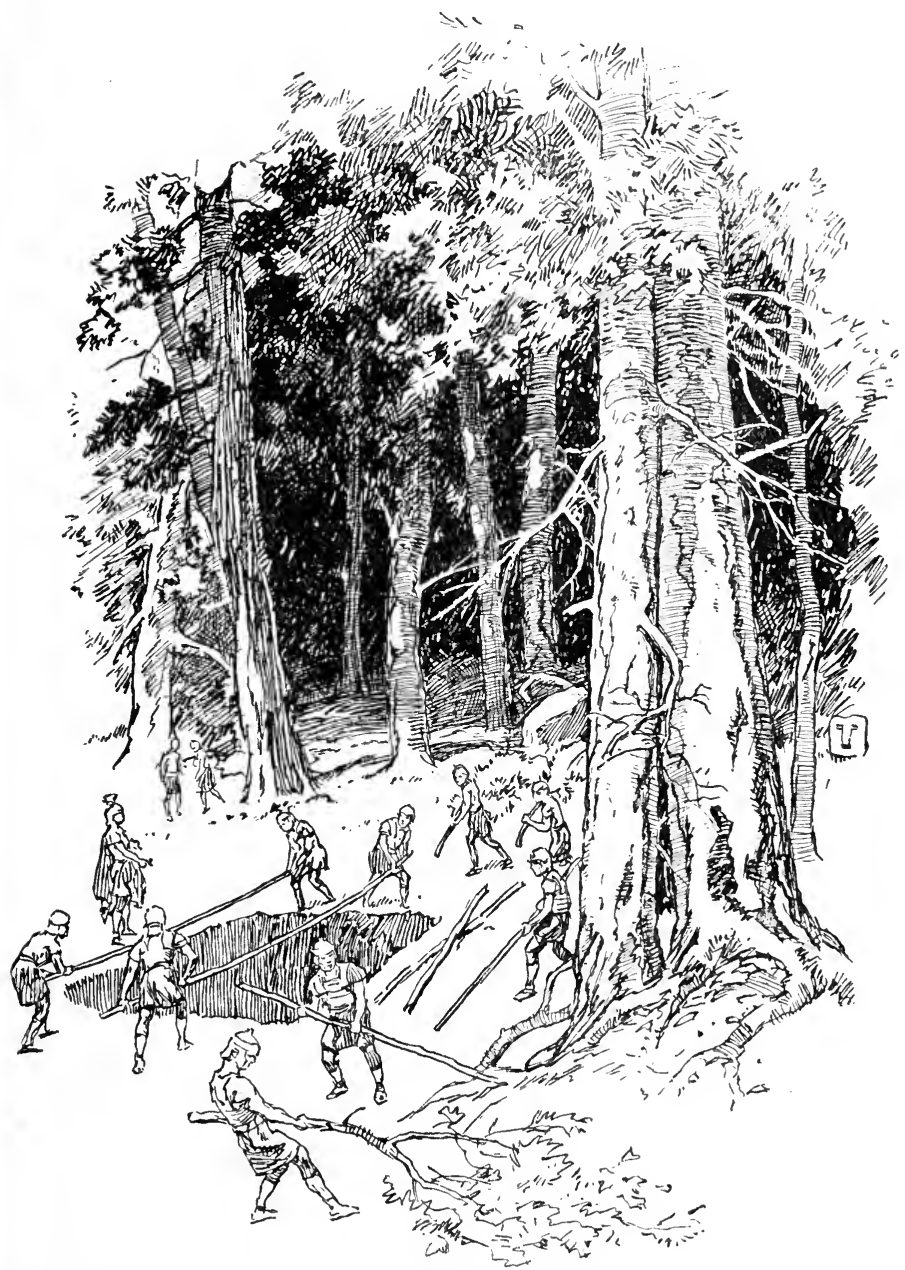

those of large cows. Crixus said these were the tracks of the aurochs. Near by they digged deep pits and covered them over with long slender poles on which they laid leafy branches. 
"By Hercules, I think we would best sacrifice a pig to Sylvanus, the forest god," said Sannio. "He is spiteful sometimes, and may do us harm for desecrating this wood. I think this must be especially sacred to him. The forest growth is so rank and thick."

"I imagine Sylvanus must be so lonely here, he would be glad to have us cut many more trees," said Titus. "At any rate, I vow to him the tall cypresses at home on which my father nails the wolf's head for protection, if he does us no harm on account of this evening's work. I would take no such risks in dangerous forests for any one but Cæsar."

"Never worry," said Baculus. "If man protects us, so tame a god as Sylvanus is not likely to harm us." "I think he stays only in Italy, anyway," said Caius. "He is not worshiped in Gaul."

"You had best fear only the storms that fell the trees and the gods of the stars and fires that dwell afar," said the Gaul; but the others gave him little heed.

And so with many a jibe at each other about their fear of Sylvanus, magic, fauns, and the like, albeit with more of dread than mirth in their hearts, the party returned to camp. 


\section{CHAPTER VIII}

THE STANDARD BEARER IS WORSTED BY A BEAST

ON the next morning, with the first light, the hunting party assembled in front of the camp. Near the person of Cæsar were grouped several of his attendants, men who were in Gaul merely as his friends, - among them Trebatius, Hirtius, Pansa, Oppius, and Metius. Three or four of his lieutenants-Quintus Cicero, Pedius, Cotta, and Galba - rode near him. Caius, Baculus, Sannio, Titus, and three or four other centurions had charge of the following of soldiers who attended.

"Let Crixus lead the van of this gay army for sport," said Cæsar. "Lanius may act as rear guard. As there are few enemies in our rear, he is likely to have a light task."

A boisterous laugh from the others greeted this order. For it had become well known in the army that Lanius was ready for all ventures except such as involved personal risk or bodily danger. However, he dropped back to the rear with a scowl on his averted face.

Crixus took his place in front as guide, a trumpet sounded, and the party set off with hilarious shouts and laughter, and many a jest and jibe.

"What a surprise!" said Cæsar. "And more so to me than to any one else. Who would have thought we would build a bridge across the Rhine, and march the Roman army into the wilds of Germany only to hunt for strange beasts?" 
"Truly," said Metius, lightly, "we might earn money by taking these beasts for the shows and the circuses at the city."

"But meanwhile the business of war would stop too long," said Cæsar. "Indeed, I am doing a rash thing to leave the camp to-day. But I have determined to lay off all duties and to have a day of happy, heedless sport. To-morrow we must be busy again."

Not far from Cæasar and his friends marched Titus and Sannio. They discussed the dangers of magic and witchery which might lurk in the mysterious intricacies of the great forest.

"Will our Italian people never learn that witches and fauns and magic do not exist and are only names with which to conjure the ignorant?" said Cæsar, who overheard them. "Here are these two men, the best of soldiers - and hundreds more like them throughout the army - who believe that there are secret dangers and mysteries and harmful spirits and gods in the woods. They are even yet, after all these centuries of Roman civilization, as superstitious as these barbarian Gauls. Hey, there, Titus, why do you fear the forests?"

"Sir, I believe in all the Roman gods, as my father before me has done," replied Titus, with a low bow. "In these dark forests I am sure there are harmful sprites which I cannot combat. If I could fight them with my sword and javelin, I would fear them not at all."

"You are right to fear the gods, Titus," said Cæsar, who, through policy, pretended a belief in the gods long after he held on to a faith only in fate and fortune. 
THE STANDARD BEARER IS WORSTED BY A BEAST I97

"But there are no such things as spirits or fauns or magic to harm you."

"With your leave, I cannot help believing in them," said Titus. "At home my father keeps a wolf"s head nailed on a great cypress at the front of the house to keep away evil spirits. When each of his children was born, three men at night went round to the doors of our home and struck them with an ax, then with a pestle, and lastly with a broom, to propitiate for us and mother the good spirits, Intercidona, Pilumnus, and Deverra. We sacrifice to the god Terminus as well as to Jupiter, Pluto, and all the rest. I feel even now my genius telling me that something is going to happen to-day."

Cæsar laughed heartily, and said, "Believe as you will, my good soldier Titus. You have all the country people of Italy with you, and it is that belief that makes Roman soldiers such unconquerable heroes, even though the whole Roman army did once refuse to enter the Ciminian forest." And he turned to his friends and engaged Hirtius in the discussion of Xenophon's treatise on hunting.

"I feel as you do," said Sannio, seriously, to Titus. "I am sure something is going to fall out wrong for some of us to-day. By Jupiter, but you gave Cæsar a good answer. But he believes in none of the gods unless it be Fortuna and perhaps Mars."

Soon the party approached the trees where the elks were supposed to sleep. Crixus had reached the place first and reported that no elk lay stretched on the ground, helpless. Likewise no aurochs had fallen into the pits. 
“"As we are out for sport," said Cæsar, "let us proceed a little farther and see if we cannot find at least a wild boar to capture."

The party advanced and soon came to ground that rose gently before them. The undergrowth grew more sparsely and the tree trunks were larger. After a little time they had reached the summit of an eminence and found that it sloped gradually away on the other side to a small treeless plain. On the border of this open space, they saw a small herd of animals feeding, all unsuspicious of danger. Crixus declared it to be a herd of aurochs. He eagerly repeated the wonders of their fierceness and danger to man and beast.

It was decided to separate the party and to make an effort to surround the plain. The soldiers were to rush upon them from all sides at a given signal, and endeavor to kill them with their javelins.

They all dismounted and crept forward. Spirits, witchery, magic, and the like were forgotten. But Titus kept near Caius. "I may owe Cæsar more as a soldier, Caius, but I grew up near you. I feel sure something will happen. You fear neither the magic of the wood nor the dangers you can see. I am strong and fear not those brutes yonder. Perhaps we may help each other. I am sure something will fall out wrong."

The two went toward the place to which they had been directed, at the farther end of the little plain. A bog at the edge of the wood obstructed their advance and delayed them. They had scarcely surmounted this difficulty and reached solid ground when it seemed that there must be some confusion as to the signal, for the 
animals which had continued feeding, now suddenly threw up their heads, at the sound of a trumpet, sniffed the air, and with a mad bellowing broke into a thundering run across the plain. The soldiers with loud yells broke cover, dashed out into the open, and began to pursue. As the signal had been given too soon, a great part of the circuit of.the plain was still clear of any men to check them. A soldier leaped out from behind a tree and hurled a javelin. It struck one of the animals in the shoulder. With a hoarse bellow of pain it dashed straight ahead. The soldier turned and ran toward where the others were escaping. Caius and Titus had rushed out, intending to pursue, but now that the beast was coming so directly toward them, they were confused and hardly knew what to do. "Let's leap aside and stab it as it tries to pass us," said Titus. But Caius seemed not to hear, for he had run straight ahead, seemingly with the intention of meeting the animal after its own manner. But just as the brute was nearly upon Caius, the latter leaped quickly to one side and stabbed. $\mathrm{He}$ was too slow and was overturned and tumbled headlong on the thick grass, while the brute rushed blindly on.

Then all at once Cæsar stood near its path. He came like a shadow from no one knew where. But there he stood, with a javelin poised, ready to cast it. The brute seemed to see him and when it was within six yards of him blindly swerved directly toward him. Then, either through excitement or over-exertion, or because attacked by one of those seizures which annoyed his later years, his lance dropped from his hand, his body grew limp, his eyes rolled upward, and he crumbled to 
the ground. In some way Titus had leaped in, and with a roll and a shove, had barely moved the Imperator out of the animal's course. Titus was himself knocked headlong by the outthrust of its hind legs as it dashed on.

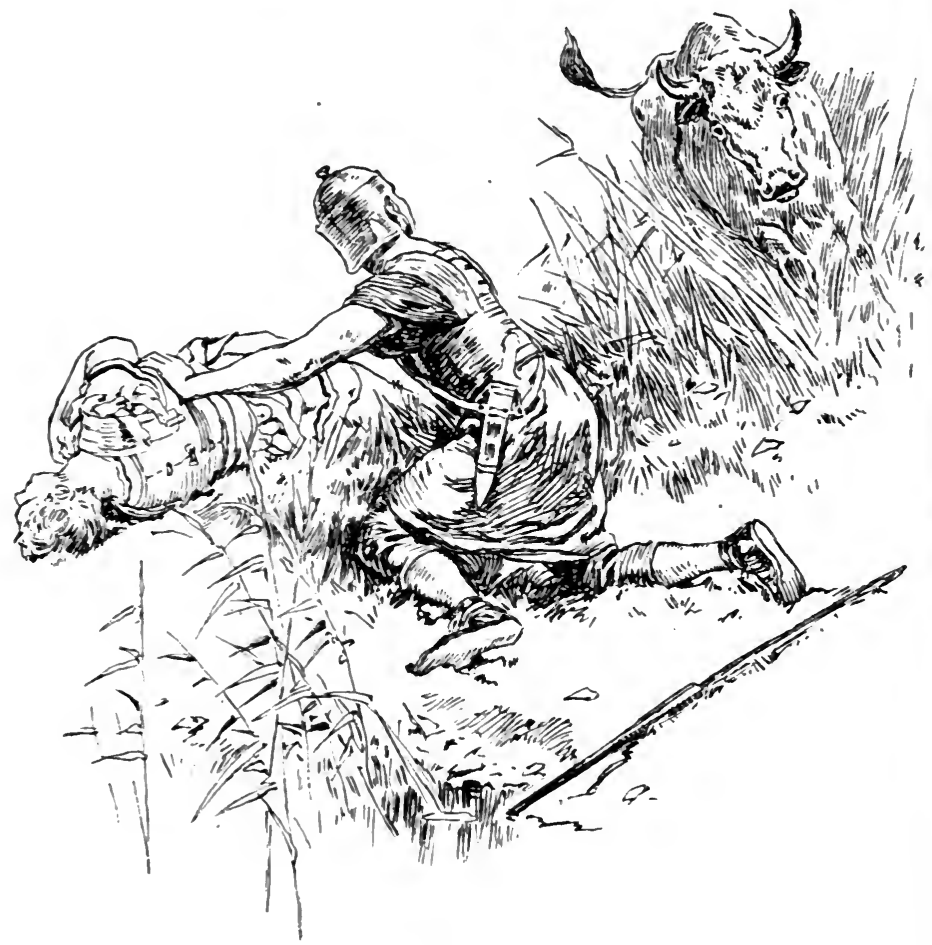

The arm of Caius had been hurt, but he was quickly up and ran to the spot where Cæsar and Titus lay. Titus was not much hurt, and was striving to rise. Caius helped him, and ran to the marsh to bring a cap of water. This he threw on Cæsar's face and also bathed his hands. He was rewarded by seeing the 
eyes of the Proconsul open; and then Cæsar sat up. "By Jupiter, but I had a narrow escape," he said. "What happened?"

The youth told him. "But where did you come from so suddenly?" they asked.

"I had ridden this way, thinking that in this quarter would be the most sport. My horse got entangled in yonder marsh, and I had to leave him there. I got to hard ground just in time to see that great brute rush out. I wanted to take a part in the sport, and thus I was here before either of you knew it. And so it was Titus that dragged me out of the way? He told me this morning that something would happen. Well, so it has. You deserve my eternal favor, Titus, and you have it. You shall be made a centurion of the first rank to-morrow. But let me charge you : say nothing about this seizure of mine. I do not wish it known among the soldiers that I am subject to them. Speak not of it, I say to you once again. But let us see if my horse can be pried from the marsh. Call some of the soldiers."

They walked to the edge of the wood, and not far away, near a huge, broad-headed white-stemmed beech, they found the aurochs struggling in one of the pits which the men had digged. 



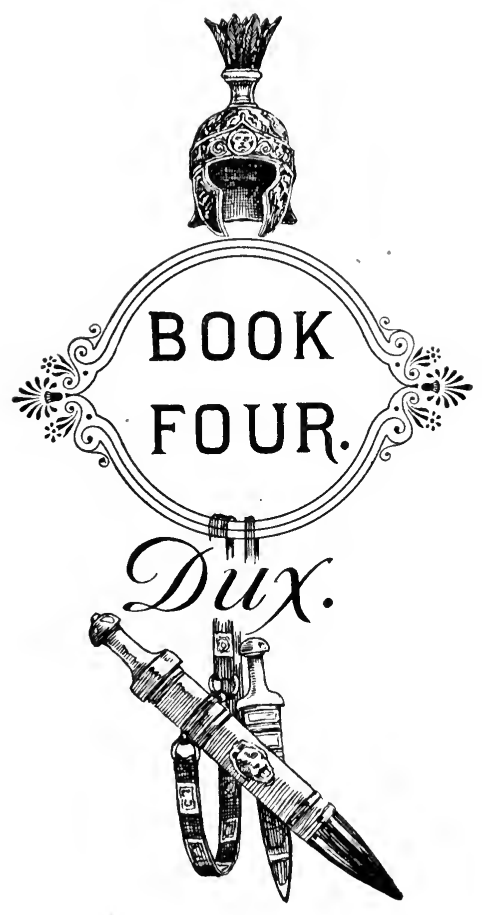




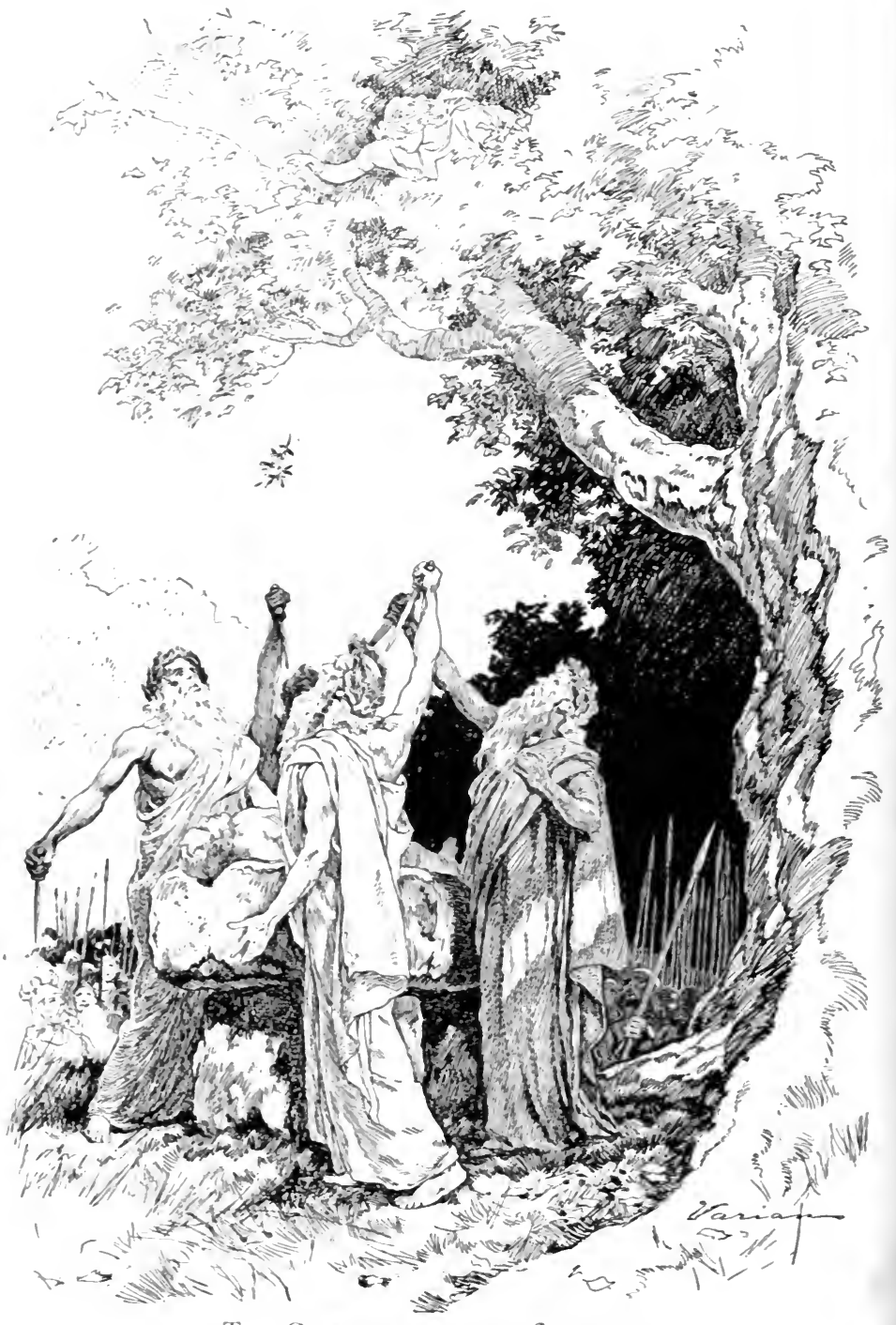

The Commander is not Sacrificed 


\section{CHAPTER I}

\section{THE COMMANDER EXERCISES CLEMENCY}

After some two weeks spent in Germany, Cæsar led his army back into Gaul, and broke down the bridge. When he had gone a short distance into the Gallic territory, he built a strong camp, with a four-story tower, and left Caius with five cohorts of the Tenth legion to hold it. They were to watch the proceedings of the Gauls in those parts, as well as to keep an eye on the fords of the river and the doings of the Germans. "Stay in the camp, Caius, as much as possible," he said. "It will be necessary for you to collect a part of the winter supply of grain for the soldiers, but it is near the camp. The Gauls at present pretend peace. But they are a fickle and changeable people above all others I have known. They will be ready to attack and destroy you if opportunity occurs. If they do attack you, fight them stoutly, always taking advantage of them in any way you can. Meanwhile, send a messenger to me, and I will bring or send you aid." "I will do my best to obey you, sir," said Caius. "I do not see why I am thus honored, but I will do all I can. Baculus can advise me, and with the cohorts of the Tenth, I think I can keep back a great force of Gauls."

"I trust you, and I fear not the results," said Cæsar.

The camp was built and provided as a winter camp. Instead of tents, log huts were built for the soldiers. A large supply of wheat and barley were to be stored 
in the quæstorium, and several wells were digged to furnish water within the walls. The men left were seasoned veterans, among them Sannio, Baculus, Titus, and several others whom Caius knew for coolness and bravery in danger.

Caius was surprised toward night of the day on which Cæsar went away to see Lanius and several of his companions come riding back to the camp, and demand admittance. All together, with their servants there were some fifty of them. Lanius showed a letter from Cæsar commanding Caius to admit them and provide him and his followers with the best quarters and food in the camp.

Caius doubted the validity of the letter, for he could see no reason why Cæsar had sent him such a command regarding a man whom he had publicly insulted only a few days previously. Yet there was the letter with Cæsar's seal, and all he could do was to admit him and treat him and his companions as well as he could.

They were no sooner in the camp than they began to be boisterous and insulting to men and officers. They seized on some of the huts and drove out their occupants. They had their slaves to fling the arms and baggage of the owners into the streets of the camp. They even beat several of the legionaries who objected to leaving their huts. Others they commanded to bring water for them and their horses. Their loud laughter and insolent looks and acts showed that they meant to carry things with a high hand.

At length, Caius remonstrated with Lanius, who seemed to be the leader of the party. At this Lanius braced himself erect, and assumed his haughtiest air. 
"I am a free man among free men, and shame to face no man. I own three villas and much money at Rome. I feed -"

"I am not concerned with all this talk," broke in Caius. "I have nothing to do with what you own or what you feed. But Cæsar has left me in command of this camp, and given me certain orders concerning it. I intend to carry them out. Now, unless you: and your friends behave more decently, you will not be a free man much longer, for I shall have you put in chains."

"Surely, you jest," sneered Lanius. "Put me in chains! Lanius, a rich Roman noble, put in chains by an upstart of a shepherd like you? Wealthy and honored as I am," he went on, "I have tried to treat you as a patrician. Yet have you refused to accept my kindness, and now you threaten to put me in chains! Bah, by Pollux, I defy you. You may not remember that Cæsar is not here to give you his aid in your great threat."

"I remember that I am in command here, and have given you warning," said Caius, and he walked away.

Lanius looked after him a moment, and then broke into a loud jeering laugh. Caius half turned, but recovered himself and went on to his hut.

The disturbance increased, and true to his threat, Caius had Lanius and several of the most turbulent of his companions put in chains. The others subsided into quiet.

Late in the night, Lanius sent to beg that he might see Caius. The latter, after some hesitation, went to the hut where Lanius was confined. 
"Sir, I earnestly beg your pardon for my conduct to-day," said Lanius, throwing himself at Caius's feet. "I am undone and ruined if you tell Cæsar of my doings. He suspects me already, and insulted me

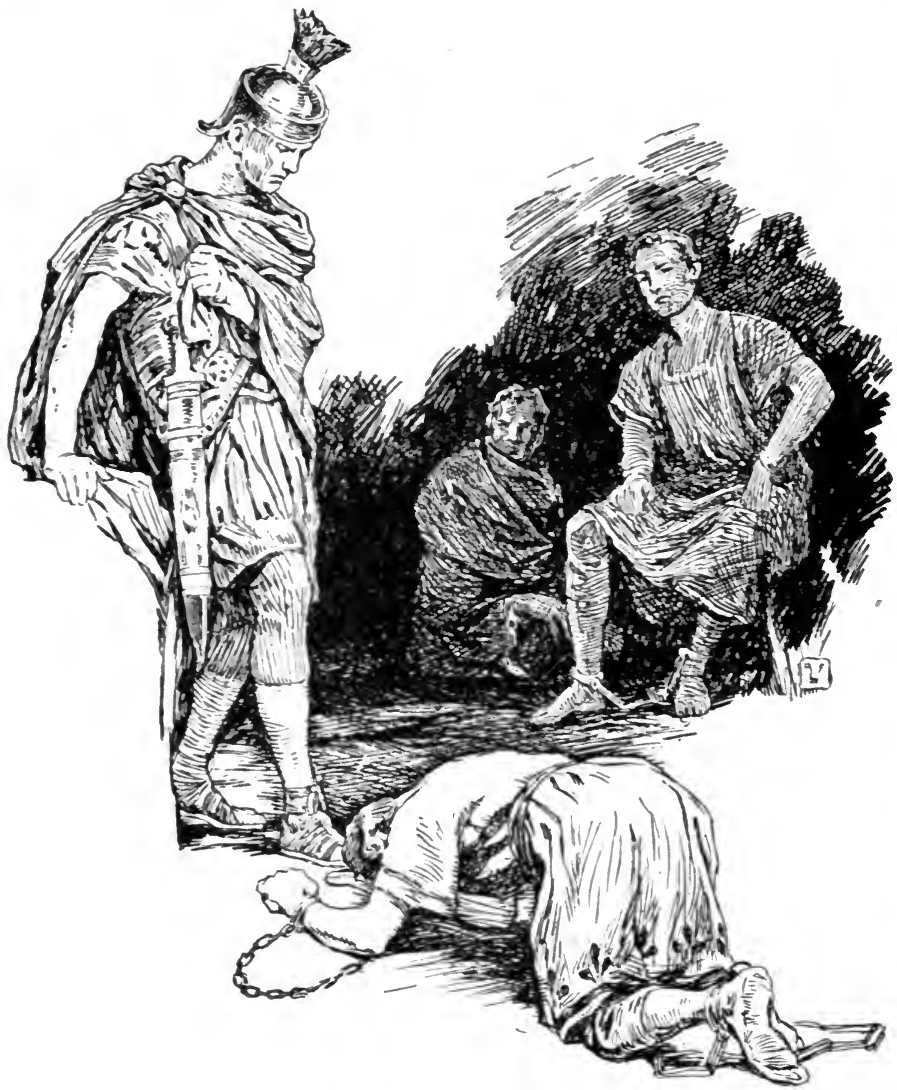

cruelly on the day of the hunt. I have done my best to be a faithful and useful man in Gaul, and yet he does not trust me, and seems never to think me in 
the least worthy of an office. A few nights ago I secured his seal and had one made like it. When we left this morning, I had grown desperate and did not care. With my friends, we lagged behind, and plundered a small group of Gallic merchants and farmers. They vowed vengeance, and said they would appeal to Cæsar. Then we were afraid to follow Cæsar further, and so we came back here. I do not know what madness possessed us to behave as we did, except that you have scorned all my efforts to be friendly. I do not know why you have done so unless because I jested with you at Spoletum before I knew that you were of any consequence. I am undone and ruined. What shall I do? I can't go to Cæsar. My acquaintances will despise me if I go to Rome. I have made the Gauls my enemies, and put myself at your mercy. I am ruined, ruined, ruined!" And he groveled on the earthen floor and moaned piteously.

Caius could but despise his contemptible meanness and cowardice, nor could he help feeling pity for him.

"It is possible the Gauls will not report your act to Cæsar," said Caius. "If you give no further trouble here, I will say nothing to him of your behavior in camp. I am willing to help you to have one more chance."

"By Pollux, will you?" exclaimed Lanius, leaping up. "You are splendid. I promise you no further trouble, and I will do more. If you ever come to Rome, I will help you to have a great deal of pleasure."

"That is enough," said Caius, with a smile. "I may never come to Rome. Guard, release this man and guide him to his hut." 


\section{CHAPTER II}

\section{THE COMMANDER IS ATTACKED BY THE ENEMY}

THE next morning Caius took about half his men and went to collect grain. This was repeated for several days. He left Lanius with reluctance, for he had never brought himself to trust the intentions of the man. But as Baculus was somewhat ill and remained in the camp, and could be depended upon, Caius felt the less hesitation. He usually took with him the greater part of the strong well men, for he was anxious to finish collecting stores before the cold of the winter should be upon them.

On the fifth day, when Caius with the foraging party was returning, and had come within a mile of the camp and stood upon the summit of a hill that overlooked the country, he saw men in Gallic costume and with Gallic standards, swarming around the camp. At the same time hoarse shouts of derision and defiance were borne to his ears through the distance. Almost at the moment, he saw the Gauls attacking the camp, and he could see only a few Romans on the ramparts, making efforts to beat them back.

"Forward, men, at a forced gait. We must hasten. We may be too late for the fighting," he said.

"Come, centurion Vorenus, you chicken," now called out Titus. "You have long boasted that you were the braver man and the better soldier. Let us see who shall be first to the camp." 
"Well enough," replied Vorenus, stoutly. "I am sure I shall be there first and cut down a Gaul before you reach the place."

There was time for no other clash between the two; for they had broken into a rapid run, closely followed

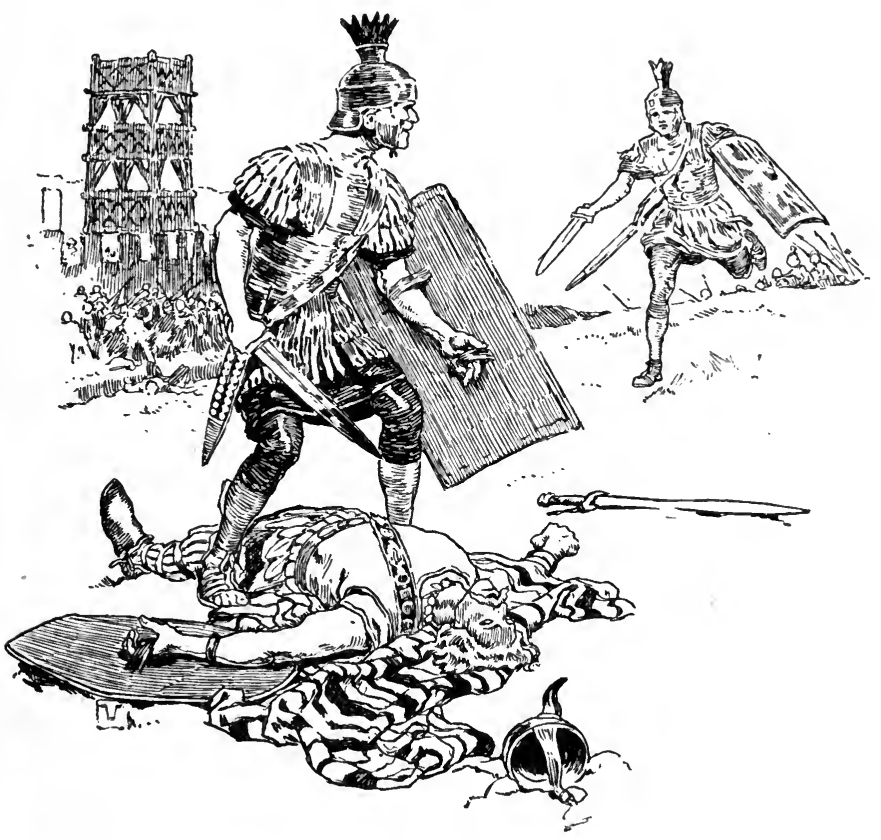

by all the other soldiers, with their armor slapping and jangling as they ran.

Vorenus and Titus had disputed time and again as to who was the better man, and would first be promoted. They had wrestled, boxed, and even fought, almost daily. Neither ever let slip an opportunity to jibe or taunt the other. 
Vorenus was the more slender and lithe of the two centurions. He and Titus now raced as for life. Vorenus soon left Titus behind, and by the time the latter and the other men came up, Vorenus had already reached the enemies' rear, had engaged three or four of the hindmost, and true to his prophecy, had stabbed one to the death.

"By the sacred standard, but I told you I would do so," good-humoredly shouted Vorenus to Titus, as the latter came up, panting and gasping for breath.

"I am not a horse to beat you running," retorted Titus, forgetting that it was he who had challenged the other to the race. "But I am the better fighter. Just see me, now." And leaping to the ranks, he called to his century and was soon in the thick of his fighting.

Caius had heard the two centurions, but with only slight attention, for he knew that the camp was in the greatest peril. Most of the men were the weaker and the less bold of the legion. Several were sick. Baculus was the only man in the camp that could be depended upon for any spirit or energy, and he had lain sick for five days without taking any food. The young commander realized with a great gulp in the throat how imprudent he had been to leave the camp so defenseless.

He knew there would be hard fighting to win into the camp through all that mass of Gauls; for now he saw the soldiers flying into the camp. Only in one place near the gate was there for but a moment some show of stout resistance to the attackers. And then he saw Baculus fall as though dead. The other Romans near the old centurion rallied for a moment, and 
fought fiercely against the Gauls who surged around. Baculus was lifted by the Roman nearest to him and passed to the next man, and so on into the camp.

"By Hercules," exclaimed Caius. "He must have been killed. He has eaten nothing for these five days."

The Gauls were taken somewhat unawares, but they faced about and boldly attacked the Romans. After a short time of stiff fighting, Caius and his party broke through, and entered the camp.

Then the leader of the Gauls desired a parley. He called for the commander of the camp to show himself upon the ramparts. Caius demanded that the Gauls retire to a javelin's throw from the camp. After they had done so, Caius mounted the wall.

"What do you desire, worthy chief ?" he asked.

"We have attacked the Romans because some of our merchants and farmers were robbed a few days ago. Cæsar promised us safety and peace. We know that those who robbed us are in your camp. If you will give them up to us, we will go away.'

The Roman youth felt that Lanius ought to be surrendered. Yet it could not be suffered that a Roman should deliver a Roman to a barbarian enemy. So he refused. But he endeavored to appease the Gauls by offering to pay for their loss at the hands of Lanius.

"We want his blood," shouted the leader. "He has taken blood from our veins, and we will only be satisfied with his. If you will not give him up to us, we will send for our allies and besiege your camp."

"I will not give him up to you," said Caius, and he went down from the ramparts into the camp. 


\section{CHAPTER III}

\section{THE COMMANDER HOLDS THE CAMP}

ThE Romans were busy late that night sharpening their swords, piling stones on the ramparts for hurling upon the enemy, and otherwise making ready for a siege, spurred on by the shouts and threats of the besiegers.

Suddenly, as they worked, upon a hill near the camp, they saw a tall bright flame shoot up, burn brightly for some minutes, and then disappear.

"That is a signal for help," said Baculus. "The Gauls send messages in that way for hundreds of miles in a few hours. What see you from the top of the tower, Statius?" he called to the watchman there posted.

"A moment ago, I saw a tall flame shoot forth from yonder hill," replied the watchman. "Now I see others and still others farther and farther away. They send a message of some sort."

"True, they send a message," said Caius. "By to-morrow they will begin to flock here from all directions. Every cutthroat and every dissatisfied Gaul for leagues about, as well as whole tribes, will come to besiege us as they did Cotta and Cicero. We can doubtless beat them off, but we must make ready."

And the Romans worked, while the Gauls made merry over the prey that had fallen into their hands. Ever and anon the Romans heard the greetings and 
shouts of fresh recruits, and they knew that with the coming of day there would be many a hard blow to strike.

With the first light, the Gauls began to press about the camp and urge the Romans to give up, as there was no hope for them. And indeed, it appeared as though they spoke truly, for during the night their forces had vastly increased by the new arrivals. Then they taunted the Romans with cowardice and dared them to come out in the open and fight like brave men.

"Only cowards and weaklings fight behind walls or play some trick of strategy," said their leader. "The Romans never beat us except with walls and tricks. Come out and fight if you be brave men."

In every part of the circuit of the walls, the soldiers listened to similar taunts. They were only prevented from leaping over the walls and fighting their tormentors by a strict order from Caius not to hurl a single missile nor leave their posts, unless the Gauls first attacked. But a particularly provoking group of Gauls laughed and shouted and hurled taunts and insults upon the Romans where Titus was posted near the century of Vorenus.

"Come over and fight if you be men," they called. "But you dare not leave your walls. You are women and cowards. Not one of you dare leave your walls."

This was continued. It was soon more than Titus could endure. "By our wolf's head," he swore, "I will show you what a Roman fighter will do without walls or tricks. Now, Vorenus," he called aloud so all the soldiers of their century could hear, "now this is the time to prove our claims to manhood as well as to teach these impudent vultures a lesson. Our conten- 
tion has already been too long. Why should we this morning hesitate to prove ourselves? What better place shall we ever find? This day shall decide for us. Come on, and follow me."

And before Caius could prevent him, Titus had leaped from the wall, followed by Vorenus, and both almost on the instant were scrambling up the outer wall of the ditch. The next moment, Titus had hurled his bull-like body upon the most closely packed part of the Gallic line. He drove his heavy javelin clear through a big Gaul, who fell with a screech of pain. The Gauls protected their fallen comrade with their shields, and cast a shower of javelins upon Titus, most of which rattled harmlessly upon his strong, ironcovered shield. But one of the shafts, more stoutly hurled, pierced his shield, and clung in his belt, twisting it far around his body, thus pulling his sword from his side to his back. The Gauls pressed closer upon him, with cut and thrust. He reached for his sword, and missed it. The delay almost proved his ruin, for at the moment when he finally secured it from his back, the blows were falling so furiously upon him, he could scarce stand. Vorenus was upon them with such skill that he drove them back and still back, until not one would come near him. But in his eagerness he dropped unexpectedly into a hole. Again the Gauls rushed to kill him, but Titus, raging and fighting like a madman, drove them away. So it was the two were still safe and had each saved the life of the other. And now in obedience to the commands of Caius shouted from the ramparts, they slowly, with faces to the enemy, returned within the walls. 
The Gauls began and kept up an attack on the camp on all sides for an hour or more, but it was fought mostly with missiles. At the end of this time they withdrew to a distance and built great fires. The Romans saw them then busy making great numbers of balls from stiff mud. These they cast into the fires. They also burned to points great heaps of small poles, cut from the surrounding woods.

When this work had gone on for some three hours, the Romans were startled by the shouts and cheers of a new band of arrivals. Looking out upon them, they saw that the last comers were enough to more than double the number of besiegers. They had soon disposed themselves about the Roman camp, a solid mass ten men deep.

Baculus, a little recovered from his wounds and sickness, watched their movements with the light of battle in his eyes, but still heavy doubt sat upon his face.

"Caius, you are commander," he said, "and have doubtless learned from Cæsar many of the things that I do not know. I have been in many a hard battle from Spain to Gaul, and have always fought out. But this looks the worst chance I ever saw. Why, there are at least twenty of them to one of us. If they had any artifice at all, they would hold our camp inside of an hour."

"By Pluto," put in Sannio, "it looks as though I might never enjoy the spending of my treasure. I wish my mother had it. I much begrudge it to yonder speckled, spotted, striped barbarians.'

But there was little time for talk as well as little 
desire for it. Posted at some distance from the camp, the Gauls now began to hurl upon it the red-hot balls of clay which they had made. The Romans dreaded them, for wherever they touched they scorched and seared the flesh with cruel pain. A perfect storm of the balls rained upon the camp. Soon one of the huts had caught fire from them, and the flames leaped forth and up with a threatening crackle. The soldiers quickly extinguished them. But three more of the huts burst into flame. They rushed to these, and now a dozen were on fire, and the lurid flames were lapping and licking in all directions, fanned by the stiff breeze that began to sweep over the camp.

Then with a rush and a yell, the mass of the Gauls dashed with horrid yells and a rumbling rush upon the camp. Hundreds of them carried bundles of brush with which they quickly filled the ditch. Then they climbed and pushed right up the walls to the wooden rampart.

The Romans had left the huts to burn, and now stood on the walls to meet the enemy. Despite the knowledge that all their baggage and property were being crumbled to ashes, every soldier stood to his place and fought, almost stifled by the billows of smoke and sparks that rolled about them. The fire raged hotter and fiercer as the Gauls pressed harder and nearer. Groans and screams of men wounded unto death mingled with the crackle and roar of the whisking flames. Many Romans fell, overcome by the heat, and many Gauls for the same cause dropped upon the earth, where they were either rolled carelessly into the muddy waters of the ditch or trampled to death where they lay. 
For three hours the attack lasted. Finally, when the flames had subsided, the Romans, breathing more freely, fought more vigorously, and soon drove the Gauls away.

The besiegers, thus beaten off, drew away out of javelin cast, and, after the Roman manner, began to build a wall and ditch about the Roman camp. As they had no picks, spades, or dirt baskets, they dug the earth with their swords, and carried it into place with their thick heavy blankets. In an incredibly short time, the thousands of Gauls had finished their work, and the Romans found their own walls encompassed by a second wall, behind which lay an enemy, seemingly determined to besiege them.

"They know our stores of provision were destroyed by the fire," said Caius, "and they mean to set themselves down here and starve us out. We must make a sally and drive them away."

"That will never do," said Baculus. "I love a fight above all things; but we can never cut our way through those walls of men. We are already wearied with fighting, and have had nothing to eat since the morning. Now there is nothing for the men to eat, so they will be strong enough to fight. Best try if you can send a messenger to Cæsar for help."

"Truly, Caius," said Sannio, "I believe for once Baculus is right, especially about something to eat. No matter how other things may press, I find it most difficult to argue with my stomach, for it has no ears."

"I trust your experience, Baculus," said Caius. "If a messenger must be sent, the sooner the better. Let us call the men to an assembly." 
As he passed on his way to the prætorium, he heard three or four of the legionaries talking and laughing, despite their burns and wounds. It seemed that they had seen Lanius attempt to shelter himself in one of the huts when the fighting began. They had seen him run out with his tunic in a blaze soon after the fire started. To them his dread of fight and fire had been equally ridiculous.

"Poor wretch," said Caius to himself. "I wonder why Cæsar has allowed so useless a creature to follow the army these years. But I guess he must expect to have some use for him somewhere. Cæsar makes and holds friends everywhere he can, or I should have publicly accused this scoundrel to him long before now."

The trumpets sounded, and the men came dragging themselves to the prætorium - those who were able. But even of these most were hurt, some with arrows and javelins, others burnt with the red balls, and still others blistered and scorched and half stifled by the flames.

Caius mounted the tribunal, and said: "Fellow soldiers, not to deceive you, we are in a close place, near our last extremes. You have fought like good and brave men. But we are without food and shelter, and cold and hunger fight against us as well as those Gauls. We cannot long hold out against them all, unless we have help. I wish a man who will undertake to find his way through the lines of our enemy and carry a message to Cæsar. Who will go ?"

At once a dozen stepped forward. Among the number were Sannio, Baculus, Titus, and Vorenus. 
"I cannot spare you, Baculus, for your advice is needed by me," Caius said. "Sannio, you would stop to joke with the first man you met. Titus and Vorenus fight too well to be spared. But Baculus may name a man of the other volunteers, and he in turn may name a second after the manner of the good old Roman custom. Who shall be named first, Baculus?" "Porcius, here, once carried such a message in Spain," said Baculus. "I name him."

A smile of joy and pride spread over the face of Porcius. "Right gladly will I go," he said. "I will fool the Gauls and steal through their camp and they will never know it."

"But you are to name another man, so that in case you fail, the other may go," said Caius. "Who shall he be?"

"I am willing to go alone," said Porcius. "But since it is the custom and also your command, I choose Lollius. He is sly as well as brave."

And so it was arranged. Late that night, when quiet fell upon the Gallic camp as though they were all asleep, probably weary with the day's labor and fighting, the two Romans slid down from the Roman ramparts on opposite sides of the camp and disappeared like ghosts into the shadows. But the men had hardly time to breathe with the thought of relief to come, when a jangle of armor and a shout among the Gauls broke upon the stillness.

At day the Romans saw Porcius and Lollius hanging head downward upon low crosses, while the Gauls surrounded them and pricked them with their swords or cut away their ears and noses. One Gaul gouged 
out an eye for Porcius and then another cut out his tongue. The two men bore their torture in silence, till they died.

The Romans upon the walls were restrained only by the knowledge that their hungry few had not the slightest chance to break over the Gallic walls and rescue their comrades.

And so no message had gone. The Gauls did not attack. They contented themselves with taunting the Romans with cowardice and failure, secure in the belief that the Romans could not escape.

At night, a hundred men offered to make another effort to take a message. "As well we few die trying to take a message as for all the garrison to starve here," they said.

Caius selected Vertico, a Gallic slave of one of the soldiers. "If you win your way to Cæsar, you shall have freedom and enough gold to buy a farm and a hundred head of cattle to stock it with," said Caius to him. "Dress in your Gallic garments and go."

The Gaul did as he was bidden, and through the darkness passed silently out of the camp. Nothing further was heard of him, and so the garrison had hopes that he had escaped to Cæsar.

Now, day after day, the men waited and suffered with pain and hunger. Caius had all he could do to keep them from breaking from the camp and making a dash to escape through the enemy. At last, on the fifth day, while in the tall four-story tower, which had escaped the fire, he chanced to notice a Roman javelin sticking in a beam. He wondered at this, and looked more closely. Then he saw that a small roll of papyrus 
was attached to it. He twisted the javelin free, and unrolled the papyrus. A few words in Greek read, "Be courageous, expect aid."

He went down and summoned the men and told them what he had found. "Let us wait," he said. "Cæsar

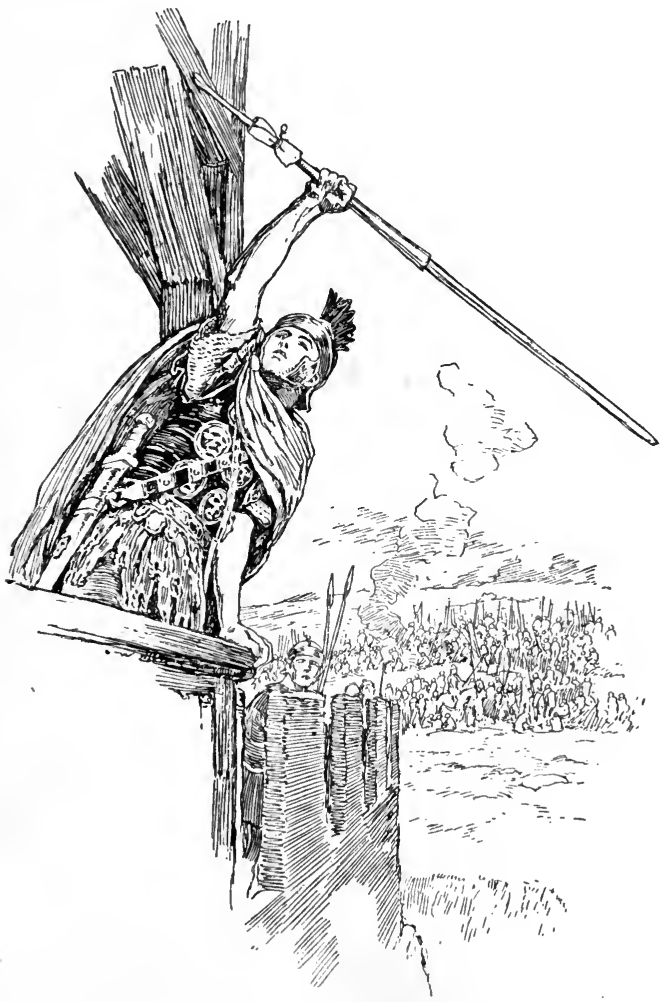

will come. Vertico reached Cæsar, and has returned to hurl this into our camp.'

Toward night of the next day, the Roman soldiers saw the Gauls, without apparent reason, begin to scatter in 
all directions, many even leaving their arms. Soon not an enemy was in sight.

"They play us a trick," said Caius. "We must stay in the camp."

"Not the Gauls to play a trick or perform a stratagem," said Baculus. "They have heard that Cæsar is coming. I am sure we shall be relieved before the night is old."

And even as he spoke, the standards of three legions appeared on the hills, the bugles sang cheerily, and help was at hand.

Cæsar himself had come. He praised the men for their courage and fortitude and commended Caius and Baculus most heartily. He heard the story of Titus and Vorenus and promoted the former toward the right and the front of the legion.

"I do not see why I too was not promoted," later said Vorenus to Titus.

"Perhaps you never hunted with the Proconsul," stolidly replied Titus. And to the inquiries of Vorenus as to what he meant, he would answer not another word.

That night when all had eaten and rested, as Caius walked about the camp, he overheard Lanius telling a group of soldiers how he had fought. They listened with slight interest, for they had heard the story of his hiding.

But no man was happier than Vertico. He was already planning the management of his farm and cattle. 


\section{CHAPTER IV}

\section{THE COMMANDER PLAYS THE SPY}

DURING the following winter, the Tenth legion with Labienus in command was stationed among the Nervians. Caius happened to learn that Labienus had ordered one of the Roman scouts to dress as a Gaul and go to Bagacum, the chief city of the Nervians. Here the men of that nation were about to have an assembly, ostensibly to celebrate some Druidistic rite, but Labienus had reason to believe that in fact it was for the purpose of fomenting an uprising against the Romans.

Caius saw the scout in his Gallic disguise as he left the camp, and it set the young Roman to thinking. He had never ceased to wish to see again the Nervian maiden whom he had assisted. He could not forget her, even during the time he thought so often of Trebonia. But it was not safe for a Roman to venture among these people, and chance had thrown in his way no opportunity of meeting her. Why not disguise as a Gaul and go among them ? The more he thought of it, the more eager he was to go, though he knew the danger; for there was great unrest among the Gauls, and rumors of a threatened revolt throughout the whole country. Especially would his situation be precarious if he should fall into the hands of the Nervian youth whom he had vanquished in the battle of the Sabis the youth who had shown such hatred of him. Caius 
had since learned that he was Carvillax, a noble of highest rank among the Nervians, of great authority since the death of King Boduagnotus, and himself a suitor for the old king's daughter. Nevertheless, Caius determined to go.

The next day was a holiday, and the Roman officers and soldiers were relieved from all drill and camp duty. Caius found a Gaul in the camp who would exchange his garments and weapons for those of Roman style; with the aid of Titus, in his tent, he was soon clad in red and blue striped, tight-fitting trousers, a red cloak over his shoulders, a brazen helmet adorned with aurochs horns on his head, and about his waist a broad leathern belt to which swung, by a chain, a long Gallic sword of bronze.

"If your mother could see you, she would disown her son," said Titus.

"So much the better," said Caius, looking at his image in a small silver mirror, a present from Trebonia. "If my own mother would not know me, I am sure the Gauls will not find me out."

"What message shall I take to your mother when I return home next year without you?" asked Titus, who was strongly against so rash a venture.

"Do you really think it so dangerous as that?" asked Caius, with some misgiving.

"Why, yes," answered Titus. "What if a Gaul speaks to you? Can you answer him in good Gallic speech? Do you think he would not know you were a Roman? What would you do?"

"I'd have to take to my heels and run," answered Caius, "for my Gallic is not good. I know only three 
or four of their many dialects. But I am going, come what may."

"Well, if you must, you must, But let's give your disguise a trial." And Titus led the way out of the tent, round a corner to where Baculus stood talking with two or three other centurions. "Centurion Baculus, can you tell me where to find centurion Sannio?" asked Titus. "This Gaul wishes to speak with him."

"He commands a guard about the quæstorium," said Baculus, looking closely at Caius, but showing no sign of recognition. "Lead him on. We want no Gauls here."

"Good," said Caius as soon as they were out of hearing. "If Baculus did not know me, it's all right. I am away."

A walk of a few hours brought him to the walls of Bagacum. The gate was open, and all who came passed in freely. The Nervians had gathered from all regions in great numbers, and although the place was of considerable size, it was full to overflowing. The narrow streets among their small, round, wattled houses were gay with their many-colored garments. Here and there were Druidic bards who chanted songs extolling the glory of their ancestors, the death of their heroes, and the promise of the gods for their future. The bards were surrounded by groups of warriors, women, and children, all of whom either joined in the song, listened with rapt attention, or cheered by rattling their spears on their shields. Caius walked among them, full of interest in the curious throng. 
Presently he saw a shouting procession following in the rear of a big Gaul who was walking toward the center of a large open space, a sort of market place. In the

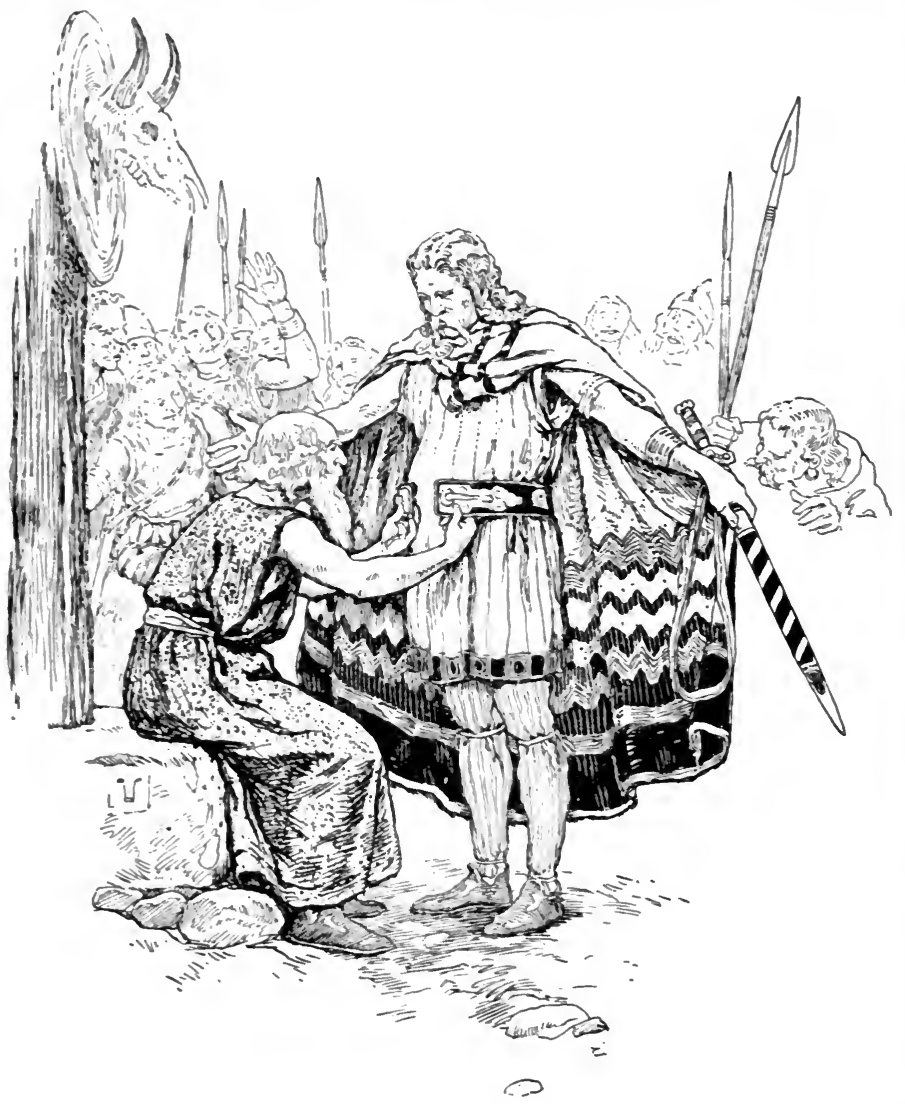

center of this space several magistrates were standing about a tall pole on the top of which was a huge shield, and on this was fastened the skull and horns of an aurochs - a sort of national coat of arms. 
"Bujorax to the measuring belt!" shouted a Gaul, pointing to the big man in the lead. "He has grown old and fat, but he thinks he can fight if war comes."

"But he can't," said another. "He has much money, and has lived too well on fat boar, sweet honey, and good mead. The belt will never reach around his big middle."

Caius followed, curious to know what they were about. He saw one of the magistrates, with an ornamented belt in his hands, measuring the waists of the men. "You are lean and strong, Segibo," said the officer to one just measured. He passed the belt about another. "It barely reaches around you, Turonix. Be careful; eat a little less. And here is Bujorax," he continued, slipping the belt about the waist of the big Gaul and drawing it tight. "What," he exclaimed. "The belt will not meet about the noble Bujorax! There was always enough of the belt and to spare before, and I have measured you once every year for the last thirty. You grow fat and lazy. Eat less and exercise more." And Bujorax turned away, much downcast because he had reached the time every Gaul dreaded - the age when he was too fat for the measuring belt to meet about him.

As Caius turned away he was attracted by a large group of men seated upon wolf and bear skins spread upon the ground: In their midst were smoking carcasses of swine, human skulls filled with sweet mead, and blazing fires to cheer the hardy men. With their swords and knives they cut away huge morsels of meat and ate them with greedy relish, washing them down with liberal draughts from the skulls. 
"Here is a bite of choice pork fit for a warrior of the gods," cried a long-faced Gaul, with huge, stiff, red mustaches. "Eat it, Bujorax. To the bravest we always give the choicest morsels. And they say you slew more Cimbrians years ago than all the Gauls together." And he extended the dainty bit on the point of his sword.

"No, no," said Bujorax, who now joined the group. "The belt would not reach around me, and I shall eat no more dainties till I grow lean again." And he pushed away the morsel, though it was plain he wanted it.

"Well, drink mead then," urged another, pushing toward Bujorax a human skull rimmed with gold. "And better, drink from my best cup, made from the round skull of a Roman I slew at Sabis. By the sacred mistletoe, but I had a hard time to bring it off. I thought I would bring away all the heads of the men I killed, but the coming of the red-coated little man changed things so I barely got away with this one and my own."

"No, no, no mead," said Bujorax. "I must grow lean again. War comes on like a bright cloud over the hills, and I am too fat to fight."

"Perhaps the brave Bujorax will drink some wine," said another as he extended a cup similar to the other, filled with wine. "We bought it from a trader and gave a stout boy for it. But we dare not tell the magistrates, for they would censure us for buying wine."

The wine Bujorax could not refuse. He had been firm enough in refusing the everyday food of the Gauls, but wine from Italy was a luxury which the fickleness of Gallic character could never resist. The old Gaul 
placed the skull to his lips and drank so greedily that the other begged him to leave a drop for himself.

A brawl in another part of the group drew attention, and Caius saw there several men pressing about another. One of them was swearing and talking vigorously. "Pay me my money," he was saying to the one who was surrounded. "Pay me my money, or I shall demand the penalty."

"I cannot pay," replied the other. "I have borrowed your money, wagered it in play, and lost it but now. I can by no means pay, and am ready to suffer the penalty. So there!"

And then, to the surprise of Caius, he saw this man led out and placed on a long shield upheld by four others, while a crowd pressed up from all parts.

"What cause for this deed?" asked a magistrate who approached.

"He sold his life for money," shouted a half dozen others. "He sold his life for money, lost the money in gaming, and now he pays the penalty."

The magistrate walked away without further notice of the matter. The victim lay stretched at his length on the shield, his head thrown far back, no sign of fear on his bold face. Then the man from whom the money had been borrowed stepped briskly up, and with a swing of his long sword smote the neck so dexterously that the head dropped and rolled on the cold and muddy ground. And now the three wives and servants of the dead man came up, each clamoring and crying for the honor of being buried with him.

Other groups of warriors stood here and there talking in low tones. Caius at last ventured to approach one 
of these groups. He found that they were talking of a war against the Romans which was now being planned throughout Gaul.

"And how stand you ?" asked a Gaul, turning to him. "For submission to the Romans or for war with them?"

"For war," boldly answered Caius as best he could in the Nervian tongue. He at once turned quickly away from the group lest he should be asked other questions, but from the corner of his eye he saw that his action had drawn attention to himself. This gave him a fright. He now realized that he was almost sure to be drawn into a discussion with some Gaul, when his speech would betray him. The consequences might be anything but pleasant. 


\section{CHAPTER V}

\section{THE COMMANDER IS MADE A PRISONER}

But Caius was loath to leave. So far he had failed to see the maiden, though he had searched in many places. Now he was just giving up in disappointment and turning away toward the town gate, when he felt himself plucked by the edge of his Gallic cloak. He wheeled quickly to grapple with his assailant, and found himself face to face with the maiden. She was blushing.

"Are you not the Roman youth who helped a Nervian prisoner walk to Cæsar's camp after the battle of the Sabis?" she asked.

"No, I am a Gaul," answered Caius, awkwardly, but his face belied his words, and he saw that he was clearly recognized.

"Yes, you are that Roman," she said, with gladness, in a low tone. "But you must be gone," she continued, with disappointment spreading on her face. "Already your actions have awakened suspicion and distrust, and you are watched. Go quickly."

"Is this the welcome you give me?" he asked gloomily. "I came only to find you."

"Hush," she said, "and go. I do not want you to lose your life. Pass between these houses here, and hurry down the street you find on the other side. It leads to a small gate that is unguarded.'

Her evident fright coupled with his knowledge of the 
situation constrained him to obey. With a farewell glance at her, he hurried off between the houses she had pointed out, and soon found himself in a narrow street, which was almost deserted. Down this he hastened as rapidly as he dared, fearing lest he should attract too much attention to himself. He was nearing the gate when the Gaul that he had heard called Segibo joined him, coming into the street from a side passage.

"What! are you leaving so early?" asked Segibo. "The assembly has not yet met."

"No, I am not leaving," invented Caius, in his best effort at Gallic. "I am going to meet my brother at the gate. He also comes to the assembly."

"As I expect to meet a friend at the gate, I will go with you," said Segibo, walking on and talking of the assembly, with frequent keen glances at Caius. The latter answered in as few words as possible, conscious that with every word he uttered he was increasing the suspicion of the Gaul.

Arrived at the gate, Segibo remained with him, and as no brother came, the Roman found his chance for escape every moment growing less and less. Some dozen other Gauls had soon gathered about the two, and Caius felt none the easier when he recognized Carvillax among them.

At last Carvillax stepped boldly before Caius and said, "Declare yourself truly. Are you not a Roman spy?"

Realizing the desperateness of his plight and hoping to pass through the gate and make a run for his life, he reached for his short Roman sword, only to find the long awkward Gallic one. Even before he could draw 
it for a thrust, Segibo had seized him about the arms from behind and held him helpless.

They dragged him with rude cuffs before the magistrate. As they went along a great throng gathered about them. "A Roman spy!" "The Roman dog!" "Kill him!" and like curses and execrations greeted his ear. Indeed, many of them struck him, leaving him bruised and sore

Then Carvillax mounted upon a large stone and began to speak to the throng that had gathered, and they fell silent and listened. "Of old, our fathers would not have dallied with a Roman prisoner. Much less would they have delayed in the case of a captive spy. Our brave and noble ancestors would have sacrificed this spy among the sacred oaks to the great gods of our people before sunset. Now, since these Romans have slain thousands of our heroes and also our good king, Boduagnotus, let us make haste to please the gods by the quick sacrifice of this spy."

A great shout of assent arose, along with a deafening rattle of the men's spears upon their shields. Then a bard in long robe, his white beard falling to his waist, stood forth and sang of the days of old, the bravery of their ancestors, and the sacrifice of prisoners that had won favor of their gods in former times. And soon the great throng was in a frenzy of excitement, and the demand for the sacrifice was loudly made from one end of the town to the other.

The Ouadd, or sacrificing priest, could make no human sacrifice without the consent of the chief Druid. So now Caius was led away into the depths of the sacred forest to the abode of the priest. 
As they went, the sun was falling low in the west, and as they passed deeper and deeper into the dim woods where the trees were larger and thicker, Caius began to feel the force of the gloom and mystery of

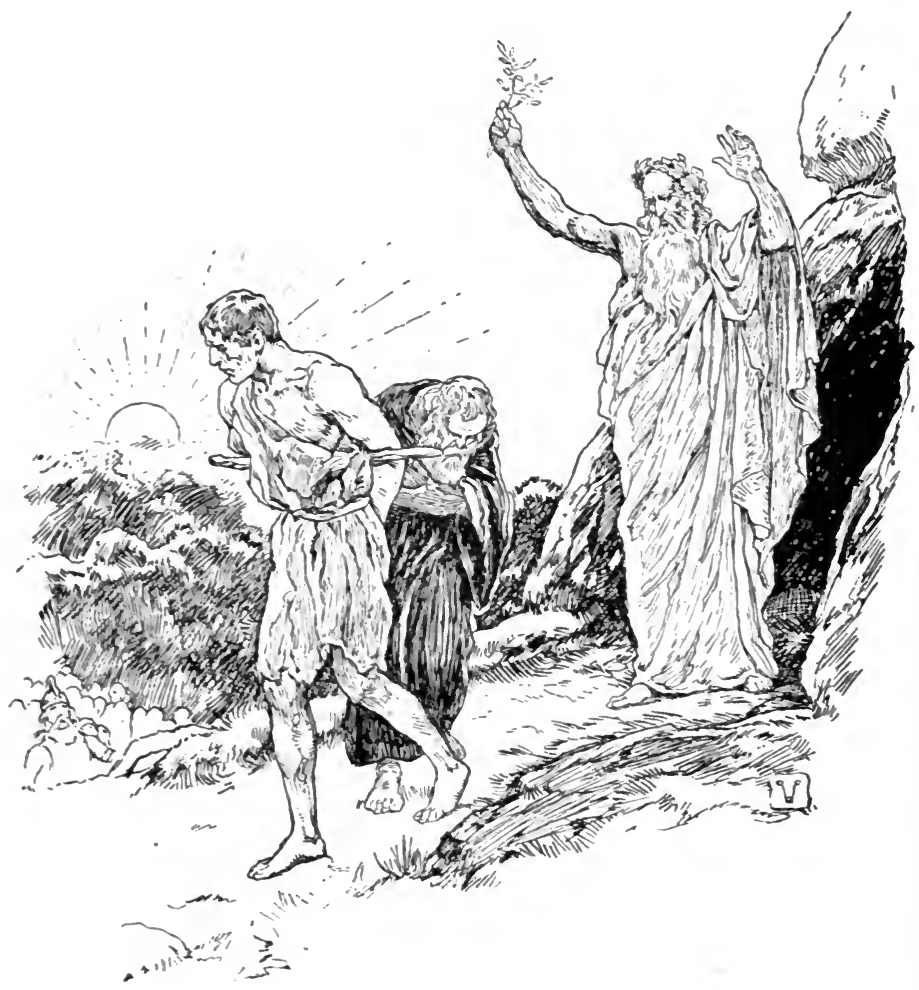

Druidism. To increase his awe, the crowd, before so noisy, now moved in silence, and only spoke in hushed and solemn whispers.

At last they approached a grove of great oaks, thicker than the others. On one side rose dimly a steep hill 
near the top of which was a dark grotto. The throng approached this with solemn step and perfect silence. The Ouadd led the way. None were admitted except the Ouadd and Caius. On a great stone seat the Roman perceived, dimly outlined, an aged man with long beard and hair, wearing a white robe reaching to his feet. On his head was a chaplet of oak leaves. About the sides of the cavern hung great branches of the sacred mistletoe.

The Ouadd talked with the chief Druid in dread and solemn tones and in words of mystic meaning, not one of which Caius understood.

At last an agreement seemed to have been reached. The old Druid dismissed them with a wave of a mistletoe branch, and the whole party returned to the town in silence.

Caius knew not what decision had been made, but from the downcast look he saw on the maiden's face as he was led through the gate, back into the town, he was convinced that he could hope for but little mercy from his barbarian captors. 


\section{CHAPTER VI}

\section{THE COMMANDER IS NOT SACRIFICED}

By the command of Carvillax, Caius was placed in one of the wattle-work huts of the town, and bound to a stout post, with just freedom enough to lie down. No one was left with him, but from the tramp of feet back and forth before the door, he was in no doubt that a guard had been placed.

Thus left alone, the young soldier's first impulse was to rail at his fate and to rage at the foolish hardihood of his adventure. Shame almost overcame him. He was one of Cæsar's trusted officers. Here he had stuck himself into a nest of danger, from which he had small hope of escape. He remembered that human sacrifice used to be made by the Romans themselves, and he had heard old Simmias tell how, once in the great wars with Carthage, the Romans had buried alive in the cattle market two Greeks and two Gauls. Much less would the Nervians hesitate to sacrifice him. He was now certain that he would be offered to the Nervian gods on the morrow, with all the horrid rites of the Druids, unless he could in some way contrive to escape. But as he could in no way imagine how this was to be done, he now wished that he had followed the advice of Titus and, at the least, left a message for his mother.

Then he thought of the golden-haired, white-armed beauty of the Nervian maiden, and of the solicitude with which she had urged him to escape. And, too, 
he thought of how unbecoming of a soldier of Cæsar to waste time in a quarrel with fate, as long as there was any hope to be placed in action of hand or brain. And he was glad he had come, and with set jaws he determined to invent a way of escape, and if he should fail in that, he would meet his death as befitted a Roman patrician.

As he could do nothing toward his escape at present, he composed his mind and soon slept, dreaming of the old shepherd days with his mother, Titus, Simmias, and even the faithful dog, on the sunny slopes of the Italian hills.

How long he slept, he did not know. He was awakened by a touch and a soft voice calling, "Caius, Caius," in a low whisper. He moved uneasily and sat up.

"Stir not; I am Bridiga," she said.

"What are you doing here?" he asked in astonishment, as he recognized her.

"You know not much of maidens," she said. "Else you would not ask that."

"You are the first maiden I have thought of," he boldly returned, forgetful of Trebonia. "But why are you here?"

"Caius, I have come to try to save your life. The young noble, Carvillax, is bent upon your death. They have secured the consent of the chief Druid, and will sacrifice you when morning comes. I have bribed the guard there at the door and entered. Take now my garments and give me yours. Dress quickly in mine and pass forth without a word to the guard, and go by the street to the left. Hasten, for the day is not far." 
"But what will they do with you when they find that you have aided me to escape?" he asked. For a moment hope had come to him and then as quickly departed; for he knew without asking that she would be offered to the gods in his stead.

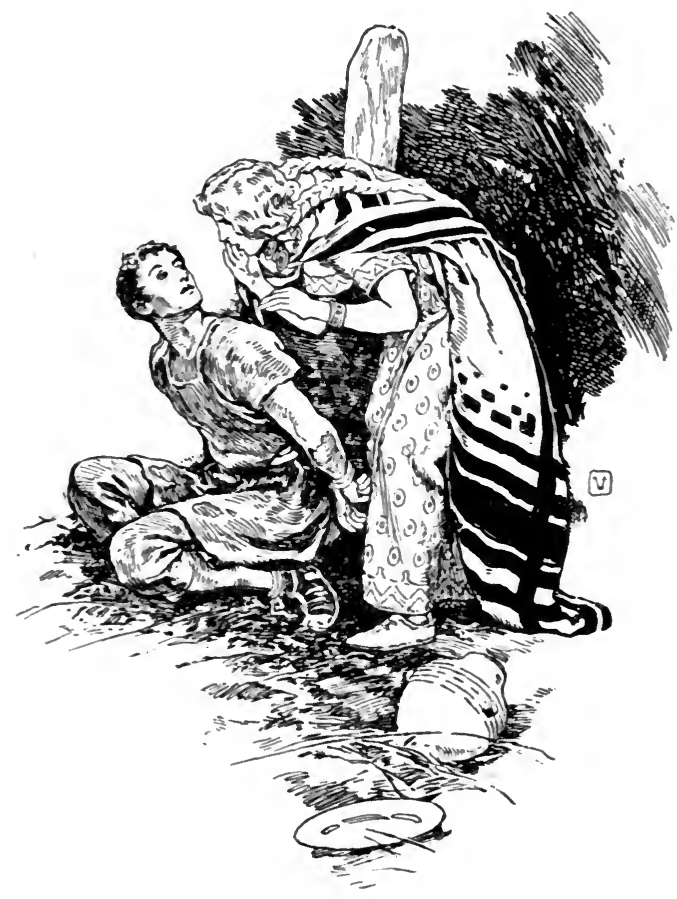

"I do not know," she replied. "It is enough if you are saved. Change garments and go quickly, now, that you may be safely out of town before day comes."

"I will not unless you go too," said Caius stoutly. "I shall not leave you here to be killed in my stead. 
Come, Bridiga, come with me. I came here to find you because I love you; and if you will, you shall be my very own, and we shall dwell at Rome."

"Oh, I cannot, Caius," she said. "The guard will not let two of us forth from the door, for he expects only me, and he is commanded to keep you even with his life. But if you will dress in my garments and go confidently, you may escape. Two of us cannot. Do, do go. If you live, we may see each other again in the future. If you stay here, you will surely die to-morrow."

"I will not go and leave you," said Caius. His tone was so grim and firm that she knew she need urge the young Roman no further.

"Then I must leave you," she said. "Even now the guard grows restless for fear of discovery."

"Why not bribe the guard to let us both out and go with us in safety to the Roman camp?" said Caius, with a new hope springing up in his mind.

But just then they heard a shout and a rattle of arms from the street. They both started with sudden dread. Bridiga remained breathlessly waiting till the noise subsided.

"Farewell, Caius," she whispered, and tenderly stroking his face with her hand, she slipped away and was gone.

Their alarm had been caused by the first stir of armed men with the coming of the day, which soon dawned, clear and frosty. All the town was astir early, men, women, and children swarming everywhere, wild with excitement. After a time, a horn sounded loudly and Caius was led from the hut. A procession 
was formed, at the head of which rode a body of armed men. These were followed by six brown-robed Bards, chanting a Druidic hymn.

Caius, guarded by eight soldiers, came next, followed by four Ouadds in their long robes. Last of all came an army of men, women, children, and dogs, barking, shouting, rejoicing, mocking, and jeering.

They conducted him into the depths of the same oak wood into which they had gone the evening before. Now, in the morning light, Caius thought he should have been able to see the woods more clearly, but the trees grew so thick and their limbs were so interlaced above, that the sunlight only here and there broke through the dead leaves still clinging to them and fell upon the dark ground and its thick coat of swamp ferns and rushy grasses. The air was damp and heavy, the shade cold and dismal. No bees hummed among the leaves, no butterflies gladdened the eye, and no birds sang among the trees.

Soon they reached an open space, circular in form, smooth and clean, about which the huge oaks stood like a wall, their long gnarled limbs forming a dome above. On one side of this space near one of the oaks stood a wooden altar, its top flat and smooth. Propped against others of the oaks, on rude pedestals of wood, were images of the Gallic gods, sad-faced, devoid of art, unsightly, covered with mold, and rotting. In the midst of the circle lay a deep pool of black water. From the huts and caverns about sounded the doleful chanting of the Druids.

Armed men stripped Caius, bound his hands and feet, and laid him at his length on the altar. The 
young Roman did not struggle, he did not even speak. He thought of the fortitude with which his countrymen had met pain and death in the service of Rome Mucius Scævola, young Manlius Tarquinius, and Regulus at Carthage. This gave him courage, and yet he was hot with shame at the thought of his own selfish purpose - the pursuit of a Gallic maid. But she had been willing to die in his stead. So he was resigned.

In a strangely calm way, he reflected that he had not seen her in the throng that followed, though he had looked for her, anxiously. Where could she be ?

He did see the haughty, sneering face of Carvillax that seemed to mock him. "He will take my Bridiga," he said to himself, with a cruel pain at his heart.

He was roused from these thoughts by the voices of the Bards, who now slowly chanted in doleful tones this song:-

\section{O our gods,}

Tarann, maker and mover of the world;

Bel, the bright sun; Heus,

The rough ruler of war;

Ognius, the priest of poetry; and all

The other gods of Gaul;

$\mathrm{O}$ our gods,

In the forests, in the flames of the fire,

In the sun's round rim,

In the moon's mild light,

In the rough rumble of the thunder,

And in the flash of the fire from the sky,

Thee we see. 


\section{O our gods,}

We know that thou art, and wast,

And will be, in time that is now,

In that to come, in all the years that are

Gone, living and being eternal,

Thee we know.

O our gods,

Thanks to thee we give.

A fell foe in war into our

Hands is come, a foe from the

Hosts of the king of the world;

For this, our thanks to thee.

O our gods,

That thou mayst bless us,

Mayst drive from our troubled land

The foes that harry and harm and

Hinder and hurt us, we pray thee,

Crush them and kill them

And drive them apart.

O our gods,

Now to thee, under the mistletoe,

Emblem of man's soul eternal to be,

This man, our foe, a victim to thee,

To please thee and gladden thee,

Him we sacrifice.

When this rude hymn was finished, the four Ouadds, wearing garlands of oak, approached the altar with stately tread, and solemnly took their places, one at each of its corners. They sprinkled some small pieces of bread on a fire at one side and poured out on the ground a little wine. The Bards called once more upon 
the gods to avenge the slaughter of their countrymen in return for this sacrifice. The Ouadds at their places, slowly, and with upturned eyes, each lifted on high his knife, bright and keen, until the points all aimed at the heart of the young Roman.

And then, from somewhere, a small sprig of brightberried mistletoe came fluttering down and dropped on his breast and lodged there. A look of awe spread over the faces of the Druids, and the knives were slowly lowered.

"The gods do not approve," whispered the Ouadds. And Caius was led back to the town. 


\section{CHAPTER VII}

\section{THE COMMANDER FIGHTS AND RUNS AWAY}

CaIUs was led back and placed in his prison again, bound hand and foot. No man among all that horde of angry barbarians, much as they wished, dared to touch him in harm, so great was the Gallic veneration for the Druids and their authority. The Roman was safe, at least for the present. But closed in his narrow prison, he could hear the muttered grumblings of the bolder spirits outside, as they strove to arouse the weaker. Above all the tumult, he heard the voice of Carvillax, raging in anger and disappointment. And the Roman knew that his Nervian rival was still doing all in his power to bring about his death.

It was late in the night before the uproar subsided. Bound as he was, and perhaps doubly guarded, Caius now lay and thought. He could picture to himself less hope of escape than before; still, sleep would not come, and he lay and tried to invent some way for loosing his cords and saving his life, hopeless though he thought it was. Then through the darkness, he dimly saw a silent form approach, quick and lithe, and again Bridiga was at his side.

"Caius, the fall of the sprig of mistletoe saved you to-day," she said hastily. "They deemed it a bad omen, and we Gauls respect signs and omens very much. But, just now, at midnight, when the deity is thought to be most propitious, they have again sought 
the chief Druid and secured his consent to sacrifice you to-morrow. I heard them talk; Carvillax plans and rules. They will build of osier twigs a huge frame in the form of a man. In this you will be placed, fire will be set to it, and you will be burned to death. You were barely saved to-day. If you are here tomorrow, there is no hope. I have bribed the guard, and he will go with you."

All this time she had been clipping his cords with a short dagger. Soon he felt himself free and a sword was shoved into his hand.

"Come, quickly now!" she said. "The day comes soon, and there is no time to lose."

And she led him out at the door, stiff from the blows he had received and from the cords that had bound him. The guard left the place without a word and followed them in silence as they hastily darted between houses and threaded narrow passages, she leading the way. Soon they reached a small gate in the wall that was unguarded, and through this they passed out into the open country. Here Bridiga stopped.

"The guard will guide you to the Roman camp," she said. "I return."

"You return!" Caius exclaimed. "I thought you were going with me."

"No, I cannot, I must return to Bagacum," she said demurely. "I am to marry Carvillax and be queen of the Nervians."

"By Pollux, you shall do no such thing," he exclaimed. "Come, you are going to the Roman camp to marry me. Lead on, guard!" And he seized her arm and led her away. 
"I did not know you really wanted me to go," she whispered, joy trembling in every breath.

"Did not know? To find you, to even see you, is the reason I came to Bagacum and nearly lost my life," he said. "Do you think I will now leave without you ?"

"Well, at any rate, you may leave without me and even yet lose your life, unless we hasten," she said. "Our flight may be discovered at any moment, and you must not think we will not be sought and pursued through all Gaul.'

And so the youth and maid hurried away, over hill and marsh, happy as a youth and maid are wont to be, despite any and all dangers.

After they had gone several miles, the stars began to fade, and the moon to grow dim. A bank of ragged clouds that lay over the east grew rosy, and a few birds chirped overhead among the rattling branches of the great oaks.

The young people now began to hope they could reach the Roman camp without being overtaken. And just then as the wintry sun arose, through the frosty air of the morning the shouts of men came faintly to their ears. Though weary they pressed forward as fast as they could drag their feet. The shouts grew louder, and they knew that they must soon be overtaken.

"Caius, hasten and leave me," said Bridiga. "I am the daughter of King Boduagnotus, and come what may, I will not be harmed by the Nervian people. I can go no further, I am so weary." She sat down. Though she had been inured, according to Gallic 
custom, to hardship from infancy, she could no longer keep pace with the seasoned young soldier of Rome.

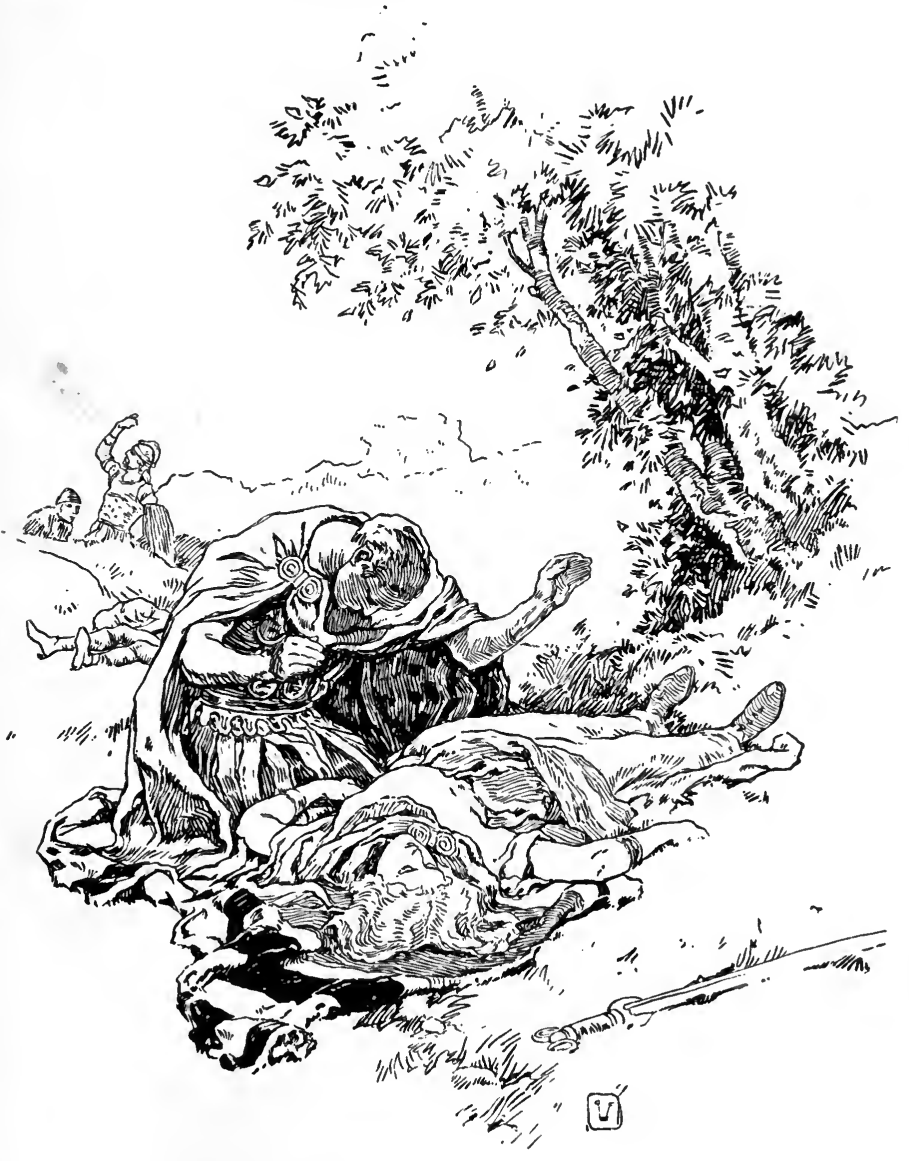

“By Pollux! I will not leave you,” returned Caius. "Come aside here, and we three will hide ourselves, and perhaps the hunt will go by us." 
So they hid themselves at the distance of a bow-shot from the road they had been following. Their shelter was one of the thick hedges of intertwined trees and bushes which the Nervians were accustomed to train for the purpose of checking the advance of their enemies' cavalry. Though the leaves were off the trees of the hedge, it was still so thick that the three were well hidden, and their pursuers might have passed them by, had not a lean dog sniffed them and come running and snarling at them. The guard struck savagely at the animal, but it dodged and ran back to the road, barking and yelping more loudly than ever.

Then three Nervian soldiers came running out to where they were hidden. Caius and the guard set themselves stoutly and drew their swords, and Bridiga grasped her dagger.

Caius found that he could fight but awkwardly with . the long, bronze, two-handed sword which Bridiga had given him. The Gaul with whom he was quickly engaged was skillful with his weapon as well as strong of body, and it was only by the greatest effort that Caius could stand before his attack. Without his shield, too, Caius was fully exposed to the furious blows that were aimed at his head. In the beginning he had placed himself before Bridiga with the determination to save her with his life, but he quickly found that in leaping to escape the blows of the Gaul, he was drawn away and had no time for anything but to leap and parry, all the time panting and drawing hard for breath. At last, however, the Gaul in his eagerness rushed with such mad fury that he stumbled, and Caius, using his heavy sword with both hands, quickly 
ran it through the body of his enemy and left it sticking. And then he himself fell, panting with exhaustion.

But he was up again in an instant. Close at hand lay the guard, dead; and near him the Gaul with whom he had fought, sorely wounded. Not far away, huddled into a knot, with a horrid frown on his face, lay the third Gaul, and close by was Bridiga in a pool of blood, pale and still.

Along the road a short distance away there now sounded the rush of large numbers of men in hot pursuit. Caius stayed only to sprinkle a handful of earth over the body of Bridiga in token of burial. Then he plunged into the depths of the Belgian forest. 
. 


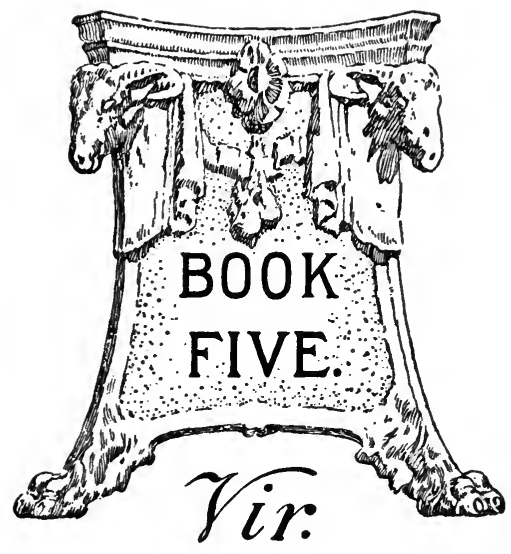




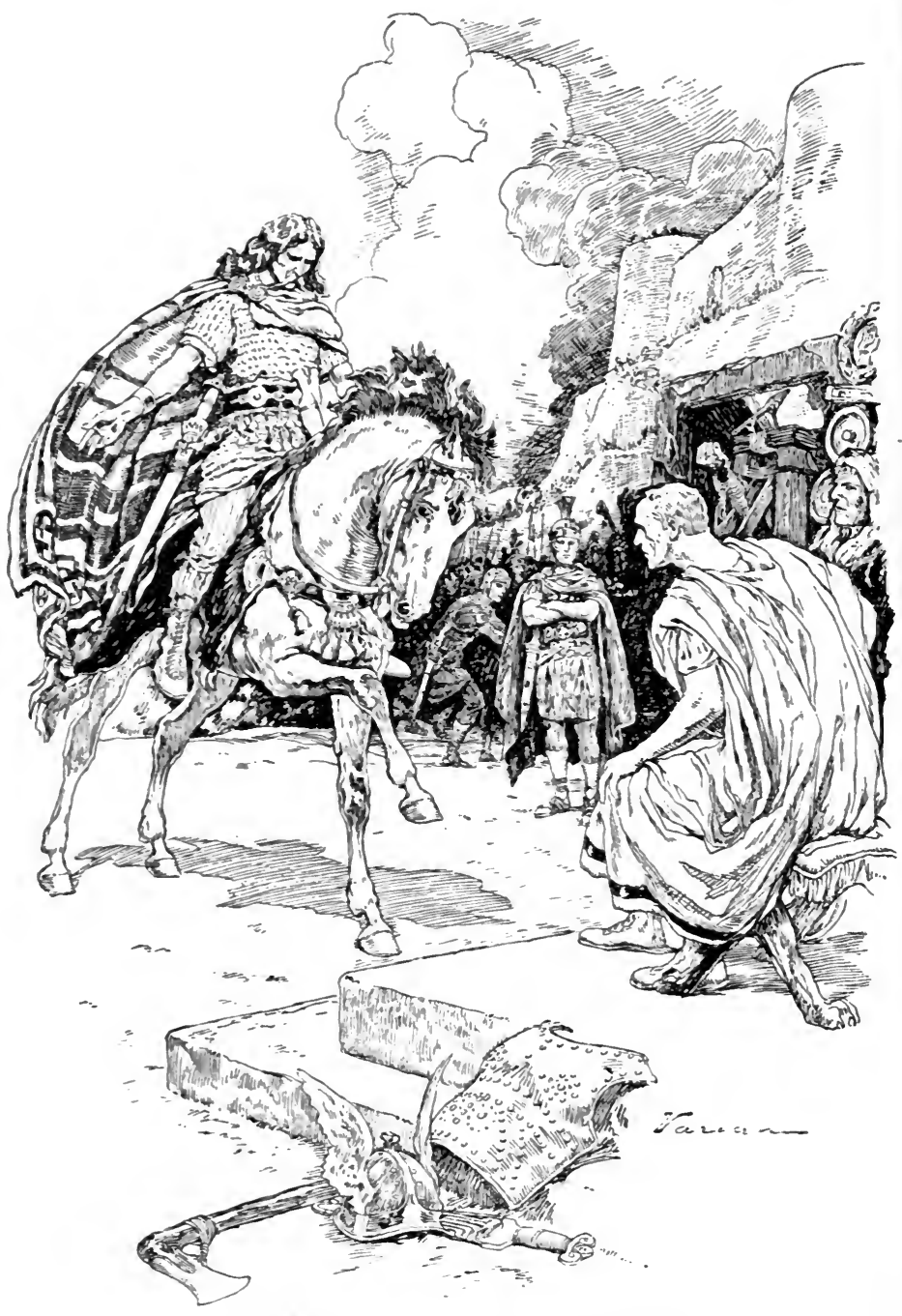

The Man sees a Great Surrender 


\section{CHAPTER I}

\section{THE MAN MEETS A GLAD SURPRISE}

ON a sunny afternoon two years after the occurrences last recorded, a Roman officer of about four and twenty, followed by a cohort of mounted soldiers, might have been seen riding, at a steady, though somewhat wearied gait, along the old Hæduan road to Bibracte, the capital of the Hæduans. He was the bearer of an important message to Cæsar's Roman agent in the town.

He was a stoutly built man, tall and straight. His face was brown with exposure, but it showed firm, strong, and kindly.

As they rode, the soldiers joked and laughed. But the young officer mused. He had spent six years in the army of Cæsar, marching up and down Gaul, across and abroad over the whole Celtic land. He thought of the thousands of lives he had seen laid down in a hundred battles and sieges. Again, in his mind, there rose the tumbling black smoke from the ashes of a thousand towns and villages that he had seen lapped up by red flames, lit either by victorious Romans or despairing Gauls. His face grew positively sad as he heard again the cries and screams of the hordes of Gallic women and children he had seen left fatherless and destitute after some great slaughter at the Romans' hands. He thought of the huddles of women and children he had seen here and there, throughout Gaul, 
bemoaning, in hunger and wretchedness, their loss of relations, friends, and liberty.

As he mused, the officer now realized that he was no longer the Caius who had entered Gaul, full of a great bitterness toward its people. He had grown to be a strong and seasoned soldier, and had risen to the rank of legatus. But he had hated bloodshed and carnage more and more with each great battle he had seen. He heartily wished it could all be ended. But he felt that such could not be the case soon. Roman arms and honor must be upheld, and above all else, Cæsar's plans must be carried out to a definite end.

And now within the last few weeks, he had seen the Roman army besiege Avaricum in an effort to put down the great rebellion which was spreading throughout all Gaul, threatening to drive out the Roman army in disgrace, and upset Roman dominion in the land forever. From the Roman entrenchments above Avaricum he had seen the smoke from twenty Gallic towns rising at the same time, and he with other Romans knew the Gauls meant to starve the Romans at the sacrifice of their own homes. While directing a cohort of soldiers who were working some engines in an attack on the walls, he had seen a Gaul who cast balls of fire and tallow upon a Roman turret, shot in the right side and killed, so that he tumbled headlong from the high wall into the fire which his own efforts had kindled. Another Gaul took his place and was in his turn pierced with a bolt, and toppled into the crackling flames below. Then another, and another, and still others shared the same fate.

"This shows," he mused, "how invincible are these 
people. Here have we been for six years trying to subdue them, and yet they fight and die. But, I remember, too, how invincibly Cæsar's men, at his command, worked away during the siege in the coldest rain and wind, with scarcely enough food to keep them alive. I remember also, that Cæsar, always anxious for the welfare of his soldiers, offered to raise the siege. 'No!' shouted they. 'Let us take the place!' Perhaps Cæsar knows that the end must be near. The gods know I hope so."

As he thus thought and felt, he was broken in upon by the exclamations of his companions at the sight of the thick walls and low houses of Bibracte, and soon he had arrived in the market place of the town, where he was surrounded by a throng of the townsmen, eager to question and learn the news.

Caius at once sought the house of Procillus, now wedded with Hilda, the daughter of Ariovistus, and living in the capital city of the Hæduans as an agent of Cæsar. The message was soon delivered and the two sat and talked over past happenings and the future prospects of Gaul.

"I am much uneased for the welfare of my land," said Procillus. "The present uprising is the greatest since Cæsar came into Gaul. Even the Hæduans here, Cæsar's stanchest friends and supporters, are restless and have been restrained from joining in the general revolt only by the belief that Cæsar is well-nigh invincible. The calls that Cæsar has made on the Hæduans and Boians have almost exhausted their resources and there has been much suffering. The younger and bolder leaders among them think this 
would be their best opportunity to free themselves from the Roman yoke. Also, many hostages given to Cæsar by other nations are now quartered among the Hæduans to be fed, housed, and clothed. There are now three hundred Nervians who have been quartered here for nearly two years - ever since those people almost captured the legion of Quintus Cicero, shortly after you were so nearly offered a victim to their gods. By the way, I saw to-day the maiden whom you so boldly and rashly went to see. She is a hostage at the house of old Coturix, the father of Dumnorix and Diviciacus.'. You remember Diviciacus as a stanch ally of Cæsar, and Dumnorix, whom Cæsar had killed for treachery.",

"I remember them both," said Caius. "But you are mistaken about the girl. I have grieved always that she was slain in the forest not far from Bagacum.'

"At any rate, the girl of whom I speak is called Bridiga, the daughter of old King Boduagnotus. She has grown to be a most beautiful and stately woman."

"I much doubt, Procillus, if the Bridiga whom I knew lives," returned Caius. "I saw her dead myself, and performed the rite of burial. But I shall soon see. If she is alive, I shall be the happiest of men, for I love her. I came to Gaul to avenge the death of my father, who was slain by a Gaul, and by his death I was disinherited of a goodly fortune and my mother left in wretched poverty. I came into this land, hating all Gauls and believing them all base and mercenary, but I have learned that I was mistaken and that there are noble and worthy men in otherlands besides in Rome. Now I have loved this maid since the first day I saw 
her, and if she be yet alive, I shall find her at once. Pray tell me how I may find the house where she is quartered."

"Old Coturix lives upon the hill over which this street passes," said Procillus. "You will know the house because it is the largest and best there. But you must wait until I can have food brought for you."

But Caius in his eagerness was already at the door, when a great tumult of voices rose and swelled and spread on the night's stillness - voices angry, snarling, full of the hoarse roar of animal savagery. The Roman youth stopped, filled with an undefined dread. "What means that?" he asked, turning to his companion.

"I do not know," hurriedly replied Procillus. "Remain here and I will find out." And so saying, he stepped forth into the narrow street, closing the door behind him.

Caius quickly placed his ear to an opening in the wall and listened. The voices had come nearer, had spread, were everywhere, now mingled with the crash of battered house walls, the occasional clash of arms, and shrieks and screams of pain.

"Why should we give all our substance from year to year to feed a Roman army that will conquer us and make us all slaves?" he heard one voice say.

"Why should we feed the Roman dogs when our own wives and children are perishing for lack of food ?" said another.

"Come forth, old Mercator from Rome. I will pay you the debt I owe you." And with this he heard a shout of pain, a curse, and a yell of Gallic triumph.

"The Gergovians have beaten Cæsar from their STANDARD BEARER - I7 
strong-walled city," shouted another. "Now is our time to drive them all from Gaul."

"Our wives and children starve in order that Cæsar's soldiers may feed. Come out, old trader in Gauls. You have often enough sold Gallic noblemen into slavery in the Roman forum. Now here is death for you."

And so the clamor swelled and grew.

"We must escape, Caius," exclaimed Procillus as he came hurriedly back into the room. "The Hæduans are in revolt and are even now killing all Roman citizens, traders, and hostages to Cæsar that they can find in Bibracte. Dress quickly in this Gallic garment and seek to reach the gates and depart if possible."

The youth's only thought was of Bridiga. If she were really alive, he must find her. Now he dashed for the door without his armor, or even his sword. Procillus barely arrested him by the arm. "Wait," he exclaimed. "Would you rush to your death? They would kill you before you get twenty paces from the door. Do as I bid. Put on your armor except your helmet, throw over all this Gallic cloak, and then go quickly as though you were a Gaul."

Caius obeyed and was soon in the street in the midst of the raging populace, moving as rapidly as he dared toward the house of Coturix. Torches flared here and there, dimly lighting a sea of faces. But Caius rapidly passed among them unnoticed, and soon reached the house he sought. At the door, he found an old man and his wife, but no maiden.

"Are you the noble Coturix ?" Caius asked hurriedly. "I am," was the brief reply. 
"Where is Bridiga, the Nervian hostage who lodges with you ?". he breathlessly asked.

"We do not know," the old Gaul replied. "She has fled."

Caius's mind was in a state of utter confusion. Would these old people wish to save the girl or would they be ready to hand her over to the Gauls to slaughter? Did they know he was a Roman? Or did they think him a Gaul? What should he say to win their confidence and thus find and rescue her? All this he wondered, as he stood a moment, with dropped head. Even while he debated this question in his mind, a knot of Gauls had gathered at the door.

"Where is the hostage that has been quartered with you, Coturix?" the leader called.

"We do not know; she has fled," answered the old man.

"We are certain she was here only yesterday; I saw her," argued the spokesman. "And how is she clean gone so quickly?"

"Friends, I have spent my life among you, in the service of the state. I have given my two noble sons, Dumnorix and Diviciacus, to serve you. If you now doubt my word, search my house," replied he, simply.

"We know you for a man of honor," replied the spokesman. "We will not search your house. Come, men, let us hasten on."

Meanwhile, in the confusion, Caius had quietly slipped past the old people, and entered the room. Passing through it, he found himself in a rather smaller room, dimly lighted. Of a sudden, he also found himself, much to his amazement, confronted by a hand- 
some creature, with long golden locks, who stood braced, with a drawn dagger, ready to spring upon any intruder. Caius stood for a moment dumfounded, then quickly recovered his wits, and drew his sword.

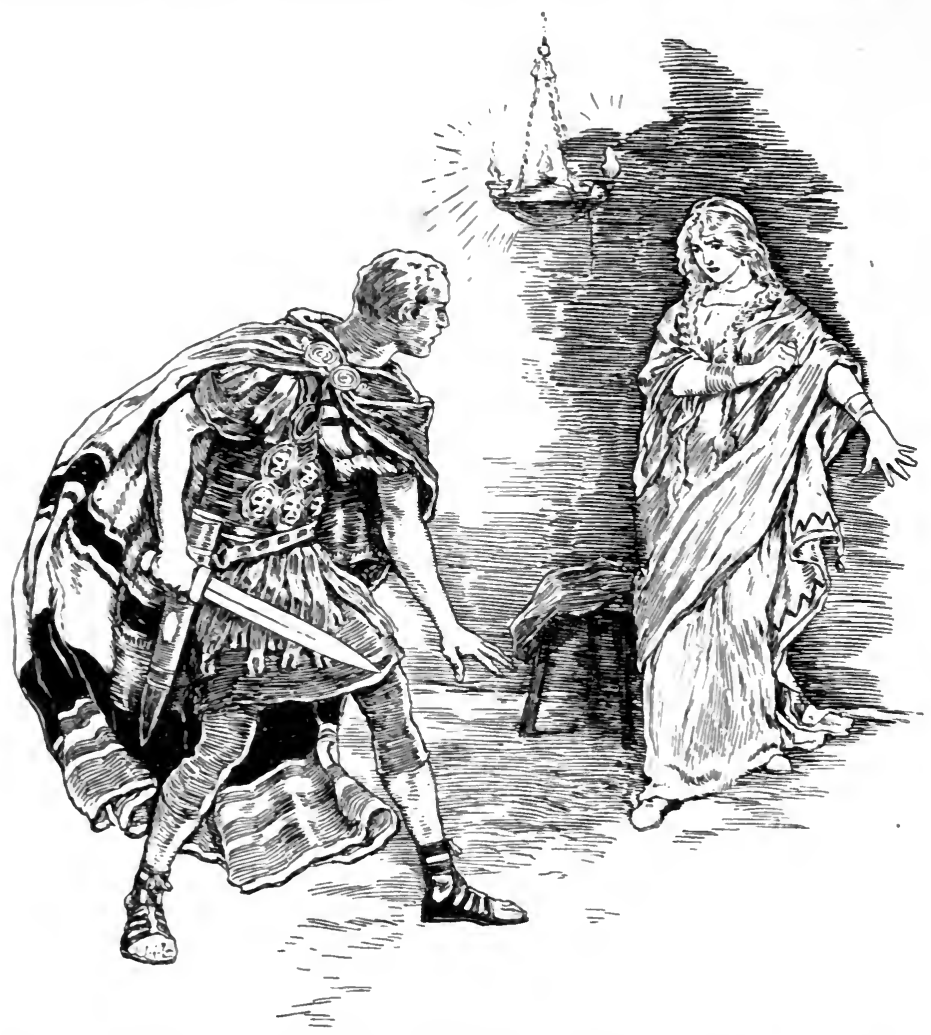

In this movement, the Gallic cloak with which he had partly covered his head, fell so that the light shone full in his face.

"O Caius, it is I, Bridiga!" she exclaimed. "Would you kill me with your cruel Roman sword?" 
"Bridiga!" he exclaimed. "Is it really you? I thought you were a big Gallic soldier ready to stab me with that dagger. How you have grown! And how beautiful! And just to think! I have thought all this time you were dead."

"And just to think," she mimicked, "I have had some thoughts, too. I thought all the time that Roman soldiers were brave. But I know one who ran away and left his sweetheart in the forest beset by enemies."

Caius turned red and tried to excuse himself, but she in jest mocked him the more.

And while they teased each other in sheer happiness, forgetful of the danger that surged about them, old Coturix came in, and seeing their glances, he understood.

"Go, my children," he said. "You must not tarry here. Others of the townsmen are likely to come at any moment to search the house. I cannot answer for the consequences if you are found. Here are Gallic cloaks. Throw them on and go. At the city gate show this ring I will give you, and the guard will let you pass. Travel by the southern road. At the great oak standing at the first brook, a small road turns away into the hills. Follow it for a mile, and you will reach a little farm, kept by Gitus, a dependent of mine. Show him the ring and ask for food and two horses. Escape to Cæsar's camp if you can. Farewell." 


\section{CHAPTER II}

\section{THE MAN FORGETS HIS MOTIVE}

Next day, Caius and Bridiga, on horses given them by the client of old Coturix, were riding rapidly southward toward Gergovia, where Caius supposed Cæsar was yet posted.

"I wish I had my cohort of good Roman legionaries," lamented Caius, as the ascent of a long hill forced them to slacken their pace. "We may need them at any time on this road, and besides, Cæsar will censure me for a careless, improvident officer."

"Perhaps you had better leave me here and go back and look for your dear cohort," said Bridiga, teasingly.

"You know very well I shall not leave you," said Caius.

"Know very well you won't leave me?" mocked she. "How should I know it? How am I to know what you would not do? Really, I rather believe you would leave me; for a soldier who will bury a maiden alive and leave her in the forest is likely to leave her again."

Caius reddened, for he had always felt that he had run away with undue haste on that frosty echoing morning in the forests of Belgium.

"But," he asked, "what is to be said of a maiden who fainted to deceive a man who had risked his life and all his military glory merely to see her? Could you think of no other way to get rid of me?"

"But just think again," she parried, "of a man who 
would go two whole years without asking after the maid who risked her life to drop a sprig of mistletoe to save him from the glory of the gods!"

"And you climbed into the oak and dropped the sprig of mistletoe?" he exclaimed. "And I had never guessed it. You were so good to me. And yet in all these two years you sent me no message that you were alive."

"They told me you were dead," she said. "And some one told me of a beautiful Roman girl. Besides, soon afterward, you cruel Romans came into our land and fought us and took hostages. I was in that number and have been held as a common slave among the Hæduans at the command of Cæsar. Oh, I hate him ! $\mathrm{He}$ is the cause of all the trouble of our people. But I love you, and because all my family are dead, I shall try to learn to be a good Roman for you." And so they joked and bantered each other as they rode.

Later in the day, on coming to a turn in the road, they saw ahead of them two persons, apparently Gauls, riding horseback, hastening forward as rapidly as possible. Caius's first impulse was to turn aside into the forests and avoid coming in contact with them, but he reflected that time was precious, and perhaps those ahead would be deceived by his. and Bridiga's Gallic disguise, and so allow them to pass unmolested. So the young people hurried on, and in a short time came up with the strangers, and were just passing when Caius and Procillus recognized each other at the same moment. The latter and his wife had barely escaped from Bibracte with their lives, and were glad enough that all might travel together to Cæsar's camp. 
For some leagues, their way lay through the land of the Hæduans. In the summer sun, the grain fields lay ripening, and herds of sleek cattle browsed in the

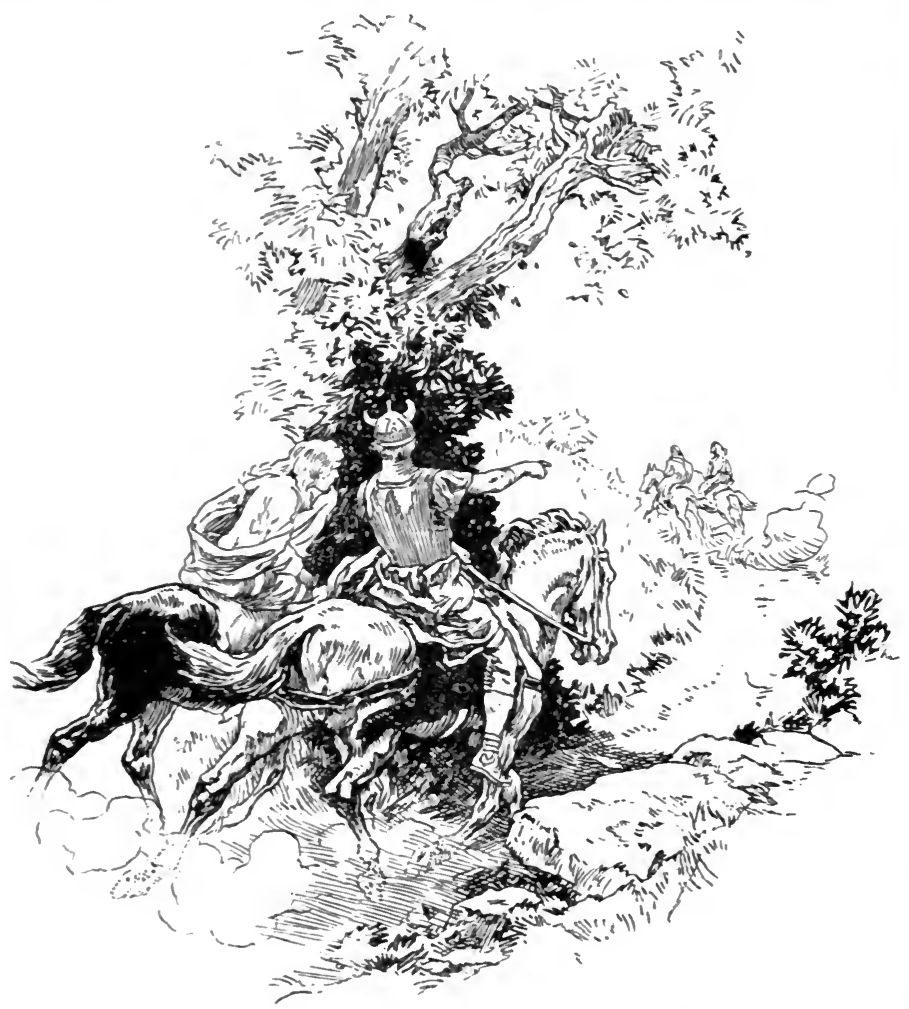

woods and grass lands. Cæsar had wisely fostered this nation that substance might be procured for his army. But soon they came into the lands of other people, and they lay blighted and bare. Houses, villages, and towns lay leveled in ashes, the crops were destroyed, and swarms of vultures showed where the cattle had 
been killed in flocks. Here and there groups of halfclad women and children huddled in hunger and misery. "Vercingetorix made havoc here," remarked Caius. "With his cavalry he means to harass Cæsar constantly and destroy all food supplies so as to force the Romans to leave Gaul."

A little farther on, they came up with a most singular group. One Gaul with ears cut off and tongue twisted out, and another with eyes gouged from their sockets, were led by a third, whose ears and nose had been sliced away. The dried and clotted blood from their hurts, splotched and smeared over their faces and bodies, rendered them a ghastly sight. As they heard the horses come up, they hastened to stagger out of the road, and one of them fell.

"O travelers, whoever you be, have pity on us and give us food," one of them cried. "For six days we have not tasted food, and our pain is great. We die in hunger and our shame is known to all men." And each wailed and wept.

"How come you in such a plight?" asked Procillus. Caius did not ask, for such sights had grown common to him in the beginning of the year, when Vercingetorix, the wily and energetic chief of the Arvernians, was making most determined efforts to force all Gaul into his army.

"O our master, because we refused to join the army of Vercingetorix, he has thus maltreated us. We had taken the oath for Cæsar. Vercingetorix has maimed hundreds of our people in this manner. Even the Romans treat us not so. But food, give us food, or we starve." 
They were given bread and bacon from the small store which Caius and Bridiga carried, but the one whose tongue had been wrenched out could make only pitiable efforts, and finally gave up, and lay on the ground, wailing and crying.

"Tell me," said Caius, "where Cæsar's army is now."

"We were told yesterday that Cæsar had followed Vercingetorix northward and now prepared to besiege him in Alesia," one of the Gauls replied. "I hope Cæsar may capture him and do to him as he has done to us. The curse of all the gods be upon the Arvernian upstart!"'

The Gauls readily told him how to find Cæsar's army, and then the four with all haste set out northwestward to strike a road leading more directly to where Cæsar was reported to be. About dusk of the second day afterwards, the party reached the Roman camp. Caius asked to be led to the tent of the Imperator himself.

"Well, Caius," said Cæsar, "the Hæduans have already repented of their rashness and sent me back your cohort, safe and sound, but I thought you were dead. A Gallic deserter told me, and I had no reason to doubt it. But I see now that you have at least rescued one of the hostages," he went on, glancing at the blushing face of Bridiga.

Caius quickly told the tale of their escape and wanderings, and his own imprudence with regard to the cohort. Cæsar saw in the faces of the two their story.

"Well, Caius, I regret that you were careless with the cohort, but I think I understand the reason why, 
and I can forgive you. Mars is often slighted when Cupid calls. I am glad to see you back, for there is great work to be done to take the city of Alesia. All Gaul has at last united, and the hardest struggle we have had is now before us. Even if I loved you but a little, I need you much. But what is to be done with the maid?"

"I would marry her if I may," boldly answered Caius.

"You shall if you will," said Cæsar. "And a right good marriage, too, for she is a princess, the daughter of King Boduagnotus, the ruler of the Nervians. And by Venus, they are the bravest of all the Gauls. They almost beat us in that battle on the Sabis."

"She has been a princess to me all the while since I first saw her, even before I knew she was the daughter of a king," said Caius.

"Well, then, Caius, you shall marry her if you wish, at a more opportune time. But I really think you could make a marriage at Rome that would be more help to you. Nevertheless, since I see your mind is set, marry her. Take your sweetheart now to the tent of Trebonius and leave her with Trebonia, and say that Cæsar begs that she will keep her under her protection. Then report to me for duty."

And Caius and Bridiga turned and started out of the tent. At the door, Caius stopped and said, "I forgot, Imperator, to tell you that Procillus also is here and wants to speak with you."

"All neglect is forgiven you now, Caius," said Cæsar, laughingly. "Tell him to come to me." And he waved Caius out. 


\section{CHAPTER III}

\section{THE MAN SEES A GREAT SIEGE BEGUN}

Alesia, where Vercingetorix had chosen to make a stand against Cæsar, was situated on a rocky eminence lying between two small rivers. On the western side of the town was a large plain, and on all other sides were small valleys, beyond which swelled a chain of hills, thus almost inclosing the town. Alesia itself was strongly walled, and the greatest portion of the eminence dropped sheer and perpendicular away from the foot of the ramparts, thus offering little promise of success in an effort at scaling.

As Vercingetorix had at least eighty thousand men shut up in the town, and Cæsar had only about fifty thousand with which to combat them, the Imperator, with his usual strategical foresight, determined to besiege the place rather than to risk an assault which would be almost sure to prove a failure.

So he summoned old Lucius Cornelius Balbus, his chief engineer, and gave his commands. Soon this officer with his assistants were busy, laying out camps on the hills and better points of vantage. Then the legionaries, with pick, shovel, and earth baskets, built the camp, strong walled and deep ditched, and joined them each to the other with long trenches and walls of earth. In some places the trench was twenty feet deep and twenty feet wide, with its sides perpendicular. 
This work was hastened day and night, and soon a line of continuous fortifications encircled the whole town. In such places as were most exposed to attack, three trenches were dug. The earth taken from them was built into walls parallel with the trenches, on the side away from the town. The wall was strengthened with hurdles and trees wattled in. At the top of these walls there projected toward the town a continuous line of bristling points formed of bushy-topped trees with the limbs chopped off and brought to sharp points, looking like stag's horns.

Outside of these main trenches and toward the walls of Alesia, five rows of parallel ditches with slanting sides were dug. In the bottom of these, sharpened brush and limbs were fastened. These were of such length that they could be interwoven above the ground in such manner as to form a stout hedge of threatening points. Still beyond this were dug eight rows of conical pits, three feet deep and three feet apart, placed checkerwise. In the bottom of each of these was sunk a stake the thickness of a man's thigh, upright, sharpened, and the point hardened with fire. Some of the soldiers called these wolf pits in which the Gallic wolves were to be caught. "No," said Titus. "They are lilies." And the soldiers laughed, some one told Cæsar, and thenceforward they were lilies.

Beyond the rows of lilies, lines of stakes were driven into the ground, and to the top of these were fastened iron hooks with barbed points. These the soldiers called "spurs." New names had to be found for these objects, for they had never before Cæsar's time been used in the Roman army. 
Before these works were finished, the Romans were one night startled from their dreams by the thunder of a great body of cavalry. A sentinel reported that it

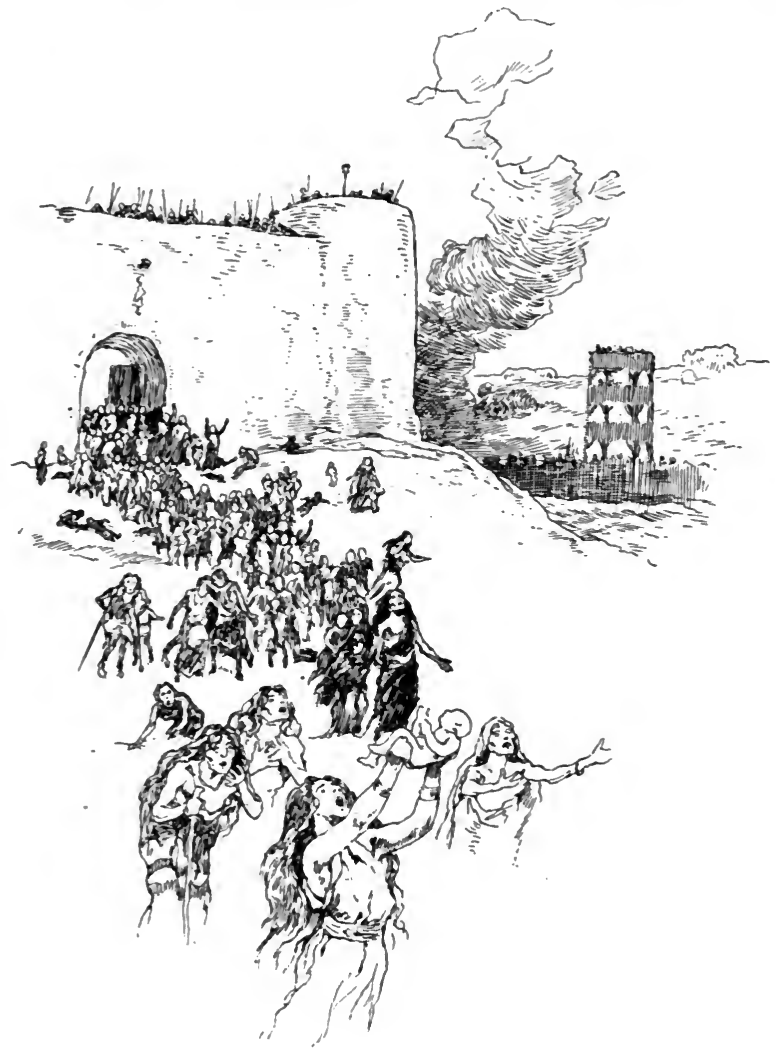

was the cavalry of Vercingetorix, leaving Alesia before it should be completely shut in. A deserter from Alesia brought word the next morning that Vercingetorix had sent away his cavalry to raise help among the 
other Gallic nations for one final, stupendous effort against the Romans.

"We shall soon have an army on each side of us," said Cæsar. "Fellow soldiers, we must hasten our fortifications."

And so the lilies and the spurs, the walls and the trenches, the camp and the towers, were built with all dispatch. The soldiers worked so willingly and with such good results that Cæsar said he could overturn the heavens with such men. And, this word being passed among them, they worked all the harder.

Then, as it was certain that an army of relief collected from all Gaul would come to Alesia, a line of fortifications similar to the line next the town was built on the outer side of the Roman army, so that the Romans themselves lay between the two lines, one next to Alesia, seven miles in circuit, and the other next to the country, fourteen miles about.

On a day near the end of five weeks, when the Roman fortifications were almost completed, at about the third watch, the Roman soldiers heard a great noise of weeping and lamenting, and looking up to the gates of the city, they saw issue forth an army different from any they had encountered. The old men, the women, and the children were being sent away in order to save the food supplies in the town for the fighting men. On they came, down the slopes, with outstretched hands, some of the women holding out their small children, pleading with Cæsar to take them as slaves and give them food. Starvation stalked in the town, they said, and one chief had even urged that the women and children should be eaten. 
Cæsar saw in this condition one of the surest means of helping to reduce Vercingetorix to submission by forcing these useless consumers back upon the town. So the Roman soldiers with spear and sword pricked them back up the slopes to the gates, amid their doleful cries and lamentations.

At the end of forty days the Roman works were completed. Hardly had the soldiers a breathing spell from their labors when the Gallic army of relief appeared upon the hills southeast of the town, a horde 250,000 strong. The Romans heard the shouts of joy in Alesia, and knew that a final test was near at hand. Each nerved himself, under Cæsar's exhortation, to do his best for the glory of the state and the Imperator.

Even the next day there was a cavalry battle, though lasting but a short time, and the Gauls had the worst of it.

Cæsar was now inclosed by 330,000 Gauls. His own army was less than one sixth of that number. But in this case as in all others, the resources and courage of Cæsar seemed to increase with the magnitude of his opposition. He put the best face upon all matters, and the soldiers were cheered and strengthened. 


\section{CHAPTER IV}

\section{THE MAN HEARS ANOTHER STORY}

AT midnight of the second day after the relief army had appeared before Alesia, Caius was awakened from his slumber by a confusion of shouts and yells, mingled with the rattle of arms, the steady call of the Roman sentinels, and the hoarse blare of the trumpets. He knew his place on the walls, as every Roman knew his place. He hastened to it, and despite the darkness and confusion, found there most of the men of his cohorts. From the shouts on all sides, he could tell that an attack was being made in the complete circuit of the outer line of works.

The Romans stood stoutly to their posts, though taken unawares. In the darkness Caius could dimly discern, at the outer edge of the second trench, the forms of thousands of Gauls, working like demons, filling the ditch with bundles of brush and hurdles, while beyond them pressed other thousands in solid mass. They hurled upon the Romans a storm of javelins, arrows, and stones. The Romans in their turn cast javelins, pointed stakes, leaden balls, and stones of a pound weight upon their assailants. Thus the Romans used no shields, and many were killed and wounded. The thuds of the stones as they struck, the hissing and whirring of arrows and javelins, the shouts and yells of attack and defense, were mingled thick with the screams and groans of death. 
But in spite of all, the Gauls were advancing. Now they had filled a ditch and were leaping and scrambling over it and right up to the wall, pulling away the pointed tree tops which still held them back. The Romans redoubled their efforts, and the Gauls were checked only on the brink of the wall.

Just at this juncture the Roman fortifications next to the town were attacked by the Gauls from within. With shouts and yells more fearful than the others, if possible, they pressed upon the ramparts. Caius was thus forced to send half his men to defend the inner wall. This so slacked the storm of missles his men had been casting upon the outer assailants, that the latter began once more with renewed efforts to make headway.

Caius realized that the situation was extremely desperate, and began to wonder why Cæsar did not send aid to this part. And just then Cæsar himself appeared.

"Why so few men, Caius?" he asked. "Have so many been killed already? Where is Lanius?"

"I do not know, Imperator," replied Caius. "I have not seen him."

"I ordered him to come to this part with three cohorts," said Cæsar. "I do not understand." And he was gone.

Then Caius shouted a few words of encouragement to his men, they fought with increased energy, other cohorts came up, and soon the enemy was repulsed in all parts.

Exhausted by this exertion, Caius at once retired to his tent for a snatch of sleep. He was so weary, 
he threw himself down without removing any of his armor except his helmet, and he was soon in a sound sleep.

He was awakened by a jangling noise and a blow upon his shoulders. He sprang up, clutching wildly.

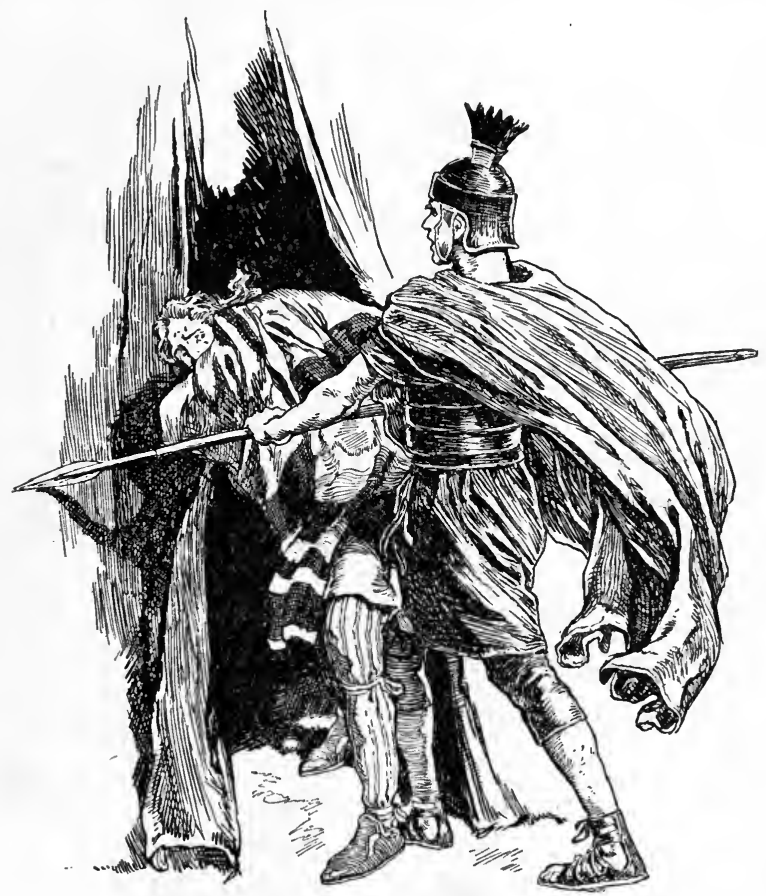

He grasped the tunic of some one who was near, and this was left in his hand as the wearer slipped away. The noise within caused the guard at the door to place his spear across the entrance of the tent. The intruder was thus stopped.

When a light was brought, the guard pulled away the 
cloak with which the captive covered his face, and there stood Eredox, at last fairly caught.

At day; Caius carried the old Gaul before Cæsar and told of the several attempts that had been made on his life, and of his belief that Eredox had made each of them.

Cæsar commanded that Eredox be led away to instant crucifixion. "You have tried to take the life of one of my best officers at a time when I most need all I have. If you had given no other cause, I would make you pay the penalty. Besides, I have some recollection of your name as one of the chief of the cutthroats in Sulla's butcheries of good Roman citizens. Let him be led to crucifixion at once, Lictor," said Cæsar.

The face of Eredox showed no sign of emotion. "If you would grant me the remnant of my life, I can tell something that might be of value to this youth here," he said, pointing toward Caius. "I can also tell why I tried to kill him and why I will never try again."

"Caius," said Cæsar, "you have served me well and may ask favors. Shall I spare the life of this fickle and treacherous Gaul who has tried so often to kill you and now claims to know things of value to you ?"

"Imperator, I much doubt him," said Caius. "Do as you will with him without regard to my poor interests."

"Then, I spare you, Gaul," said Cæsar, "in the case of your telling a straight tale. If you do not, it may be the worse for you, yet. There is time to hear you now. Your countrymen are not likely to attack my camp this morning. So proceed." 
At a signal from Cæsar, all others retired except Caius and Eredox. The latter then began: "To go back so all will be understood, I was born a noble of the Senones. At twelve years of age, I was given as a hostage by my people to the Allobroges, and they after a time treacherously sent me as a hostage for themselves to Rome. There I was finally freed from all restraint, saw something of a gladiator's life, and at last enrolled as a soldier in the legions of Sulla. I served through all his campaigns and came to be well known for my bravery in the battle of Chæronæa. After Sulla's return to Rome, during his proscriptions, I was constantly engaged in aiding him to rid himself of his enemies, receiving many and ample rewards.

"One day Lanius, a rough butcher, who lived near the cattle market and who had saved a little money, came to me and proposed to divide with me the rich estate of this youth's father if I would safely get him out of the way. I wanted to know of what crime we could accuse him, so we would have at least a shadow of an excuse in case any questions were asked. He said we needed no excuse, except the wealth of the man, and that he was guilty of no crime whatever. To kill him and secure his property would be easy and safe in the excitement of the times. I was not difficult to convince, as I had already carried out two or three such schemes, and really felt little fear. So I killed him in his own house with the aid of two other Gauls, but he fought more fiercely than we expected and he killed both of my friends."

Caius had sought his sword and half drew it from its scabbard. 
"Hold, young man, and be quiet," said the old rogue, coolly. "I have Cæsar's promise of safety. Besides, I have not yet told the thing that may be of help to you."

"Yes, Caius, he has our promise," said Cæsar, with that calm that showed when his greatest rage was suppressed. "Let him proceed."

"Under pretense of necessary legal delay of I know not what sort, old butcher Lanius put off giving me my share of the booty. I went to him for it time and again, but always there was some reason why it was not ready for me. Others for whom I had performed similar services put me off in the same way. Meanwhile Sulla settled the legion in which I had served, at Spoletum, and allotted me a considerable property there. But I wished money so I could live at Rome. I had grown too old to be a gladiator again, and had worn out the bounty of Sulla. Soon he retired to his villa and died. Then I had nothing further to depend upon.

"So I went to old Lanius a last time and asked for my due. Once again he tried to put me off with some idle excuse. He was living in grandeur in the house of Caius's father. I was angered beyond what I could bear. So I slew him there and escaped to my little farm at Spoletum, where I lived till Cæsar's coming to Gaul. All the time I was living there, this youth," indicating Caius, "dwelt near by, but I did not know who he was.

"Now, why have I tried more than once to kill this young man also? you ask. At Spoletum, when I tried to take his sheep, I had no care as to whether I 
killed him or not, for I did not know him. I only wanted a sheep or two. Later when I heard that there was a young Lanius with the army of Cæsar in Gaul, I knew he must be the son of the old Lanius. So I went to him and told him my story and demanded payment of him. He said he had no clear title to the property and might yet lose it. If I would kill young Caius, he would divide. This I tried more than once to do, but always failed. Every effort has been made in the night after we had planned it well. When Cæsar prepared to embark for Britain, Lanius planned to decoy Caius into the forest and force him to sign a deed to him for all the property, and Fortune helped us, for he rambled away into the woods just at dark. Lanius, myself, and two hired Gauls followed him, and we were sure we should succeed or kill him. But Fortune failed us, and he was rescued at the last moment."

"Here, Imperator, is the very paper they tried to force me to sign," said Caius, drawing the papyrus from his belt. "They dropped it as they left, and I found it and have kept it till now."

Cæasar ordered a lictor to bring Lanius before him. "He proved a coward in not leading the cohorts last night as I commanded him, and now I find he is an assassin besides. I had hoped all the time to make the fellow of some use to me."

"Now," went on Eredox, "you can see why I shall never trouble young Caius more. There is no hope of profit in it. Lanius will know that I have betrayed him and that I have revenge upon him and his father through the punishment you will wreak upon him. I rejoice in that, and shall be glad to face him in a trial 
before you, and to see his hateful face work and draw with fear, and to see his cowardly cringing and pleading for your mercy. I am old now and poor. If you allow, I shall go to my people, and spend my last days with them."

"We have heard you patiently, Eredox," said Cæsar. "The man whom you murdered, the father of Caius here, was the best friend of my youth, almost a father to me, and I find it hard to keep my word not to do you harm. I shall send a guard with you to the edge of the camp. Beware lest you ever trouble me or any of mine again. Come, Balbus, and guide this brute to the gates, and see him well without.

"I grieve that we let this old scoundrel go free," said Cæsar. "Your father was my dearest friend. He favored me and helped me at a time when I most needed it, and I could crucify his murderer with good heart. Perhaps now you understand why I have wished to aid you in some slight degree. We shall see if we cannot recover your property, too."

At this moment the lictor returned to say that Lanius was nowhere to be found in the camp. 


\section{CHAPTER V}

\section{THE MAN BECOMES A LIEUTENANT}

THE relieving hordes of the Gauls had now been defeated in two assaults on the outer fortifications of the Romans. It soon became clear to the Gallic leaders that their followers were becoming discouraged. Unless a victory were soon won, the men would lose heart and leave for their homes. Hence the chiefs set to work with cunning energy to discover if there might be some weak point in the Roman fortifications which they might attack with greater hope of success.

On the northwest of Alesia they found out there was a large and high hill which on account of its extent old Balbus had left entirely without the wall, which ran at its base. The Gauls learned that this was the weakest place in the Roman lines and that it had been left not strongly guarded. They determined to storm this point with sixty thousand of their best men picked from all Gaul.

On the third day later, about noon Caius stepped from his tent, which was placed near that of Cæsar. Not far away rose a tower used by the Imperator for a scrt of lookout over the entire line of fortifications. As there had been no fighting during the morning, the tower was occupied only by a few sentinels under the command of Titus. Caius walked leisurely over toward the tower. 
"Hello, Titus," he called. "What see you from your high perch? Do the Gauls bestir themselves to-day ?"

"Scarcely at all," returned Titus. "They seem to have grown careless. I wonder if they have decided to give up fighting and mean to besiege us."

Caius saw Titus whirl and look toward the northwest hills, from which point now rose the shouts and yells of attack, the rattle of spears and shields, and the clash of swords.

"Awaken the Imperator, guard," shouted Titus. "The Gauls are attacking the legions of Antistius and Caninius at the northwest hill."

At the same instant, Caius saw thousands of the besieging Gauls leap forth from their camps and rush upon the Roman works in the plain, while their horns called to battle from hill to hill. They were answered by the blare of the Roman tubas, the Roman battle shout, and the heavy running of the armor-clad legionaries to their places on the ramparts.

Cæsar, already mounting the tower whence he might have an outlook over the whole field, was, even before he reached the top, giving orders to his couriers and officers, swarming at its foot.

The besieged Alesians came pouring down from the town with weapons, movable pent houses, ladders, hurdles, bundles of brush, wall hooks, and engines to attack Cæsar's inner lines of defense. At the same time, thousands of women and children appeared on the walls of the town, their hair streaming, hands extended, wailing, crying, praying, urging the men to fight stoutly, and not to give them over to Roman slavery. 
Cæsar's army was thus attacked in strong force, both front and rear. Cohort after cohort was hurried to the point of assault, and each Roman knew that his own life depended upon beating off the enemy. Mass upon mass of Gauls pressed to the attack, feeling that this was their last chance to crush the Romans and to free themselves.

Where Caius was posted, there was little fighting for more than an hour. He and his cohort were compelled to hold their places and watch the struggle in other parts.

"How goes the fight at the hill ?" shouted Caius to a messenger who hurried past.

"It is being fought hard and bravely," panted the messenger as he dashed on to Cæsar's tower. "The missiles have given out."

A few moments later Caius saw Labienus hasten past with six cohorts to the aid of Antistius and Caninius.

"Hurrah, Caius, we are going to have a pretty fight now," called out old Baculus as he marched past. "They say these men at the hill are the best fighters among the Gauls."

"Caius, if I don't get back alive, be so good as to see that what plunder I have collected and my will are sent to my mother by the cattle market at Rome," said Sannio. And the cohort had passed out of earshot.

The battle had raged for some hours. The Gauls seemed no nearer to breaking the Roman lines than ever before. Caius was just beginning to think the battle would end without his cohorts' striking a blow. Even as he thought, a storm of Gallic shouts broke upon 
his ear from the rear, and turning, he beheld wave after wave of Gauls rolling down from the gates of Alesia, straight upon the point he was holding. He scarcely had time to array his men at the townward wall before arrows, stones, and heavy javelins thrown by the Gallic soldiers and engines began to fall upon them. Under cover of this storm of missiles the Gauls advanced with a rush, under the command of Vercingetorix himself. Besides their swords, spears, and shields, the first ranks bore in their arms great bundles of brush and hurdles. With these they filled the ditches and scrambled over, mass upon mass crushing forward, though hundreds fell to be trampled upon by still others to come. Soon they approached the main wall, and with hooks fastened on long poles, began to tear away the wattled covers of the palisades. They worked furiously, while from their rear the arrows, stones, and javelins fell upon the little band of Caius in an ever thicker hail. The Romans stood firm, hurled their javelins, and cast stones and leaden bullets, but the Gauls pressed on in such heavy masses, supporting each other, pushing on up the face of the wall, that at last their faces were beginning to appear above it, their big blue eyes flashing with the rage and madness of battle.

Then the Roman short swords began to weave back and forth like the shuttles of so many looms. Titus stabbed a Gaul who had reached the top of a scaling ladder and stood ready to leap upon the wall. He fell headlong, roaring and screaming, and dragged down with him two others into the great ditch. And yet others were not lacking to take their places, and still 
they swarmed upward on their ladders, and still the Roman swords worked, cut and thrust, edge and point, and filled the ditch with the bodies of the Gallic slain.

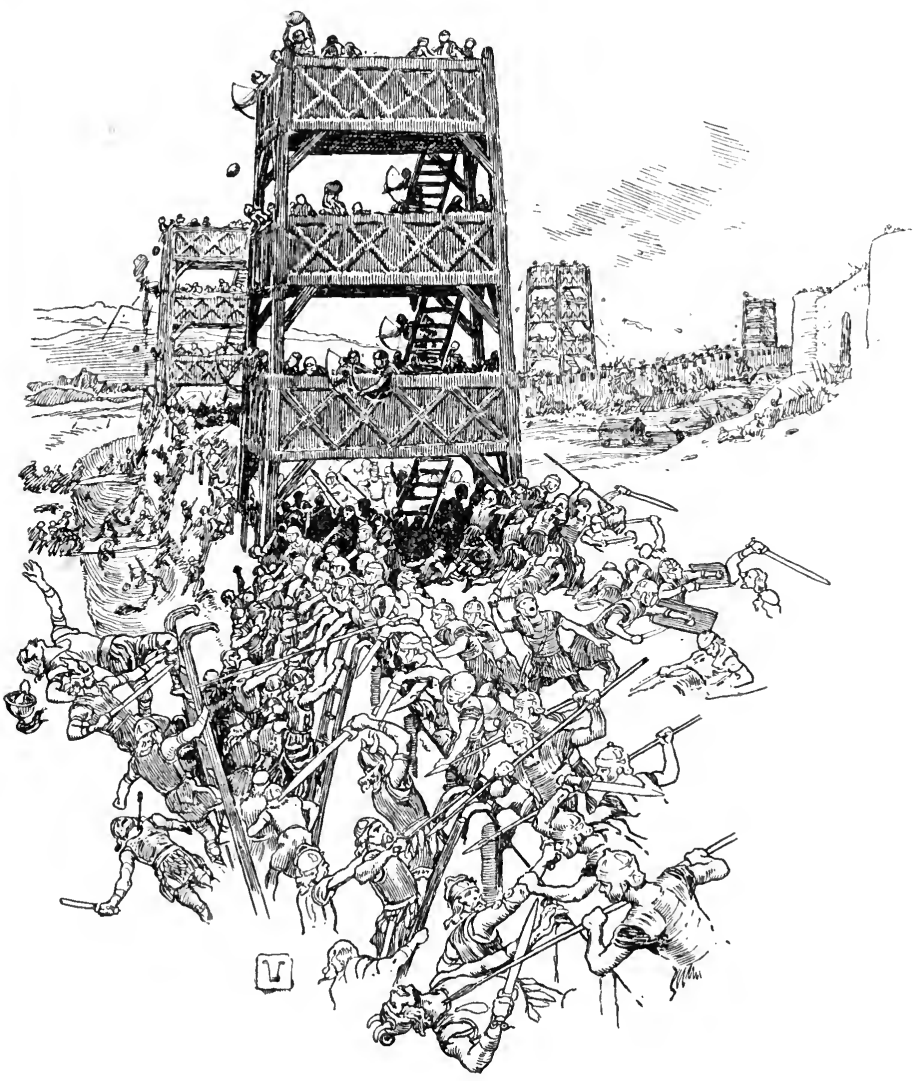

But the Gallic missiles cast from the rear were not failing to find marks among the legionaries. Almost half the Romans were dead or wounded. A stone of a pound weight broke the sword arm of Titus and killed 
the legionary behind him. The Roman line constantly fell thinner and more ragged, and ever the Gauls pressed closer and harder.

Caius himself, dizzy and half crazed with pain from a stone which had struck his head, ran up and down his lines, encouraging his men, slaying a Gaul here and another there, and seeming to be everywhere at once.

But now the lieutenant Brutus came to his aid, sent by Cæsar with six cohorts. The Gauls were driven down from the wall, but again the masses pressed together, and came climbing up. The fresh soldiers fought stoutly, encouraged by Brutus and Caius, but the swords and missiles of the Gallic hosts began to thin them down. Cæsar, perceiving this from the tower, sent the lieutenant Fabius with seven cohorts more. The slaughter raged afresh, and now a scaling party was led by Vercingetorix himself. The command of the Romans at this point had fallen to Brutus and Fabius, and Caius stood at the head of the few remaining men and fought, sword in hand.

Then right in front of where he stood, Vercingetorix himself appeared at the top of a ladder, shouting, encouraging his men, and striking with all his might. For an instant his fierce eyes rested upon Caius, and with a savage yell he braced for a spring upon the youth. Quick as a flash Caius had prized off the hook of the ladder. With a long swing it reared and fell backward, crashing with its load of Gallic warriors among their companions on the ground, slinging the chief far over among his rearmost followers. At once a cry arose that Vercingetorix was killed, and the Gauls ceased their efforts and fled. 
Caius and his legionaries dropped on the ground exhausted. But at the same instant they sprang up again, for they saw the purple cloak of Cæsar, passing on horse, rushing breakneck to the northwest wall, where the fighting had been hard. They saw the Imperator reach the place, and they saw the Romans, sword in hand, sally over the wall. A moment later they saw the Gauls flying by thousands, closely pursued by a large body of German cavalry which Cæsar had sent by a roundabout way to take the Gauls in the rear. And then had begun one of those routs of which Cæsar was accustomed to write, "and many of the enemy were cut down by ours." The Gauls fled like mad, running over and trampling each other, pursued, hacked, hewed, and ridden down by the hordes of fierce, crested Germans.

Nor did the Gauls stop at their camps. They dashed right over and through them, and on into the forests and hills. The combined forces of all Gaul were totally defeated, and the siege of Alesia was over.

Thenceforth, Gallic liberty was at an end, and the Gallic land but a Roman province. Never again would the Roman matron dread the Gaul at the gates of Rome. 


\section{CHAPTER VI}

\section{THE MAN RECEIVES HIS GREATEST JOY}

ON the next morning quiet reigned about Alesia. On the outer hills and in the great plain no Gaul was seen except those who lay stark and dead, pierced, hewn, crushed, or impaled upon the lilies. From the town no shouts, no rattle of armor, no battle calls, came down to the Romans. The legionaries swarmed over the hills and the plain, burying their own dead, and stripping from the fallen Gauls their gold and silver ornaments and such other articles as struck their cupidity or fancy. Roman traders were everywhere, eager to buy bargains in slaves and plunder from the soldiers.

As Caius walked among the outer defenses, he came upon Titus, tugging at a richly dressed Gaul who had fallen upon a lily and been impaled upon the sharpened stake. The fire-hardened point, now smeared with blood and bits of blackened flesh, thrust forth from his back. Caius came up just as Titus with his great strength succeeded in dragging the body out on level ground.

"What have you found here, Titus?" he asked.

"A rich booty," grunted Titus, with a shrug of satisfaction. "Enough to support me at Rome for a year." And he fell to undoing a heavy collar of twisted gold from the massive neck of the barbarian. 
Something in the appearance of the Gaul caught the attention of Caius, and turning the stiffened body so he could see the face, he recognized Carvillax, his Nervian rival and personal enemy. Caius quietly returned to camp. Here, at last, was one enemy who would trouble him no more.

After a time, Cæsar, clad in a rich toga, came from his tent. He mounted the tribunal, and busied himself giving orders and dispatching messengers. Now, all of a sudden, a single, long-drawn, doleful note from a Gallic trumpet sounded upon the walls of Alesia. All eyes turned up in that direction.

Presently there emerged from the gates a single figure, mounted on a splendid white war horse. Calmly and leisurely the figure rode down the hill, entered the gates of the Roman camp, and circled slowly about Cæsar and his officers. When he had completed the circuit, he brought his horse to a stand before the Proconsul. For a moment he looked straight into the eyes of Cæsar, and then he said, "Cæsar, you have vanquished a brave man, you yourself the bravest of all."

And every beholder believed him brave, and not one but looked with admiration upon the handsome form and noble bearing of this prince among the Gauls, the bold and wily Vercingetorix, chief of the Arvernians. He wore a finely wrought shirt of chain mail, richly ornamented. On his legs were varicolored trousers, the characteristic garment of his race. His head was bare. From his well-formed features shone forth clear, flashing, blue eyes. Great ringlets of long waving hair hung upon his head, and a long tawny 
red mustache curled fiercely above his thin proud lips. This was the one man of all Gaul who had shown himself a worthy antagonist of even Cæsar.

After his first words he sat his horse, still and silent for some minutes, then slowly dismounted, drew off his armor, and sat down on the ground at Cæsar's feet, saying never another word. This was his surrender. The first and the last organized resistance of the Gauls against Roman dominion was forever broken. In the hearts of the officers pity stirred for the misfortune of so brave a foe, and they spoke no word till after Cæsar had ordered Vercingetorix to be led away and placed in chains.

Then Cæsar commanded the Gallic prisoners thus surrendered to march out of the town and to pile their arms within the Roman works. As the famished thousands staggered past, with cries and curses they cast their weapons, a mountain of steel and bronze grew, and beneath it lay buried Gallic liberty. Food was supplied to the starving Gauls, and then one was given as a slave to each Roman soldier, who in most cases immediately sold his Gaul to the traders to be disposed of in the slave market at Rome.

When Cæsar had thus made disposition of the prisoners, he looked around on his officers, and with a smile said: "Fellow soldiers, you have all conducted yourselves most soldier-like. Our arms have been successful beyond our greatest expectations. Such victories have not been won since Alexander conquered Asia. The plunder and prisoners are yours. Now, there is one other reward I wish to bestow in your presence. Lictor, request Fannia, the wife of Tre- 
bonius, to bring the Nervian hostage that I intrusted to her care."

Presently there issued from a large and splendid tent near the tribunal the Roman matron, Fannia, and with her two other women. One of them was Trebonia. The other was clad in a soft robe of white wool in the Roman style, bound about with a rich tasseled girdle. She was a young woman of singularly graceful and noble bearing. As they came nearer, Caius could scarcely believe his eyes when he recognized her as the beautiful Bridiga, paling and blushing by turns, and her face growing soft and glad when her eyes had lighted upon him.

"Here, fellow soldiers, is a rare jewel which I would bestow in marriage upon our young soldier and officer, Caius Volcatius Tullus. She is a Nervian princess, and he a Roman patrician. They have been true to each other in the greatest danger, and have in turn saved each the other's life. Now may you all join me in wishing them long happiness in their mutual love." And there among the sights and sounds of war they were married in accordance with the good old Roman customs.

Trebonia, light and happy, wished them well, and forgot them quickly, for she was busying herself in an effort to enmesh the lieutenant, Antistius. And she was rewarded. He loved her for six whole months.

As Caius and Bridiga walked about the camp in the afternoon, old Matho, the merchant, met them, bowing and smiling, and seeming almost beside himself with joy.

"By all the gods, but here is my little Bridiga. She 
is the one who nursed me back to life, Caius. I taught her Latin, our tongue. And how you have grown! I never thought I should see you again. And here you

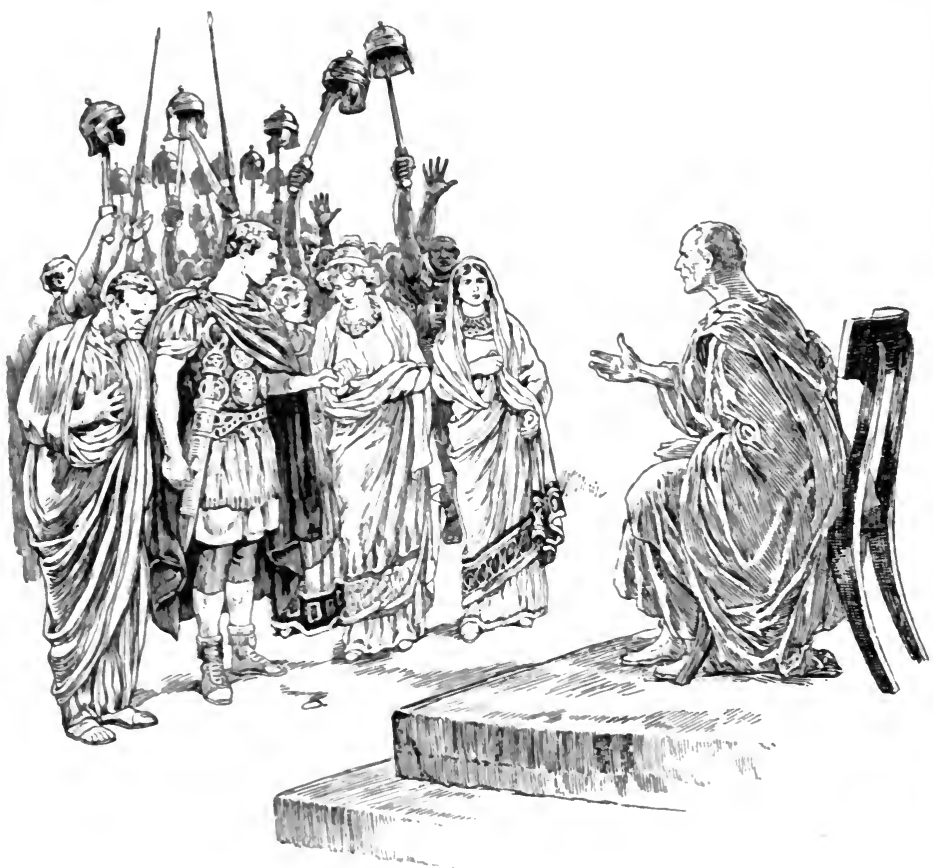

are the wife of my good friend, Caius. How glad I am that this is so."

"I am so glad to see you, Matho, too," said Bridiga. "And how do you fare?"

"Ah, well enough, to-day," he said, trying hard to subdue his joy to becoming soberness. "Truly the gods have blessed me. Cæsar paid me double for what I lost in his service, and I have traded with it and made much gain. To-day I bought many captives. When 
I sell them at Rome, I shall be rich, rich, rich, and my daughter, Nigra, just your age, shall live in a palace." And he laughed broadly, already forgetful of Caius and Bridiga and everything else, save his own good fortune. The young people passed on.

As all things were now settled, and Caius and his mother were once more independent and likely to soon come into possession of their former property, Caius urged his mother with her household, Simmias and Chloe, to come to Gaul to live. But she wished rather to pass her last days in the comforts of the City, and so removed to Rome.

Caius was appointed to high office in the province under Cæsar, and he, with Bridiga, dwelt in peaceful content in Gaul, ruling with justness and moderation. He was promoted from time to time, and did all in his power to aid in improving the condition of the Gauls, the people whom he had once so hated. He took a most active part in spreading throughout Gaul the civilization of Rome. He founded schools, built roads and canals, encouraged improved agriculture, and established law and order.

And in the culture and civilization which have always distinguished the land where Caius dwelt, may still be traced much that is due to his efforts. For to the work of Julius Cæsar and his devoted followers in Gaul is due the staying of the tide of barbarism rolling down from the North, till Rome could spread her law and culture, and thus prepare the ground for the broader, richer, and nobler civilization which blossoms in their stead. 


\section{CHAPTER VII}

\section{CONCLUSION}

Eighteen years after the taking of Alesia, on a spring day, when all Italy grew fresh and sweet with greening trees, bursting blossoms, and singing birds, a portly Roman, clad in the toga of a provincial governor, entered a little shop near the cattle market at Rome. He was followed by two stout youths, who, from their fair features and robust forms, were evidently his sons.

The keeper of the shop, an old man with the scarred face and the erect carriage of a soldier, bowed low. "Your humble servant, sir," he said. "What comfort can my poor shop offer you ?"

The other peered hard into the old shopman's face and said, "Do I again see Sannio?"

"Caius Volcatius Tullus, by Pluto!" almost shouted Sannio, for it was he. "And what brings the governor of Gaul into my poor shop? And how have you been? And are these your boys? And where is the princess Bridiga?"

"Not so fast, Sannio," laughed Caius. "I cannot answer all your questions at once, but I'll begin with your first. I am in your shop because I wanted to see an old friend, one who shared many a danger with me, and one who helped me to learn to be a soldier. I have been well, and I have prospered. I am in Rome to 
place my sons to study under the famous rhetorician, Porcius Latro, who has such crowds of young men following him about the forum. I also came to take possession of the property that was my father's. By

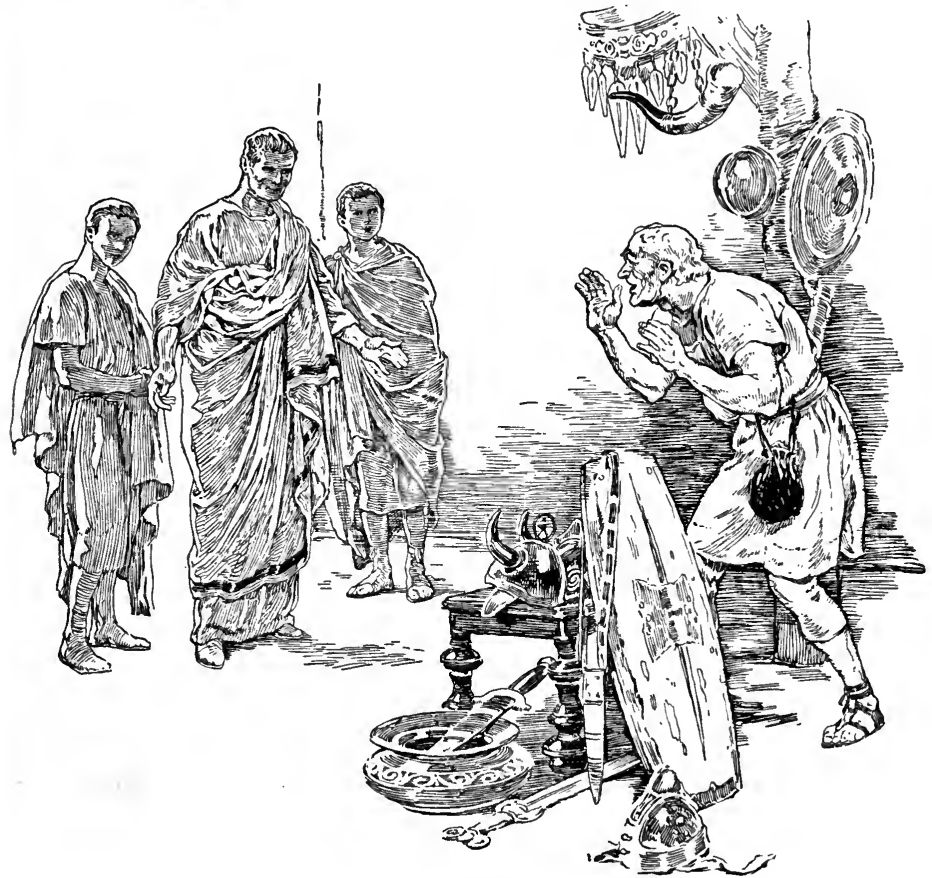

a law which Cæsar secured, it fell to my mother. As she is now no more, it is mine."

"Ah, that reminds me of that villain, Lanius, who tried so often to kill you," exclaimed Sannio. "Bad enough end came to him. You remember, he deserted Cæsar before the walls of Alesia and fled, no one knew whither. Well, he joined Pompey in the hope of promotion, and then lived fast for a year or two. He did 
not get the office he wanted, and soon he deserted Pompey, and attempted to get to Cæsar again with important letters of trust. But Pompey caught him and had him crucified head downward along with some common thieves."

Caius expressed no regrets, for he felt none. Forgiveness and love toward enemies were not traits of Roman character.

"But tell me of yourself, Sannio," he said.

"Oh, I have lived along as best I could since I grew too old for service in the army, and hung up my sword in the temple of Mars. My mother died, and this little place that I had given her, now serves me as a shop where I may earn a living, though as the proverb goes, my teeth sometimes grow too long for lack of use on solid and plentiful food. But one glory I have. I went through the wars with Cæsar. Alas! a black day it was for Rome when he was struck down. We shall not see his like again."

"No," said Caius. "Common men such as we are not capable of estimating the greatness of Julius Cæsar. But tell me of Baculus."

"Ah, old Baculus," said Sannio. "By the Roman eagles! How he loved a fight! He would leave the richest plunder in any battle for one more stroke at the enemy. He was a soldier, too. Such are not seen in every legion. And he died a soldier's death. In a battle, with the Parthians in Asia, he was attacked by four light-armed Parthians. After he had killed three of them, the last one ran and was so hard pressed by Baculus that he dropped his spear. It lodged point backward and up so that Baculus dashed head- 
long upon it, and thus tore out his vitals. The other soldiers grieved long and sorely for him."

And so they discussed others of their old comrades. The two boys listened with wide-awake interest to the stories these two old soldiers told of the many scenes of blood and carnage they had seen in the Gallic land.

Late in the day, Caius and his sons bade Sannio a reluctant farewell, and then departed to seek the teacher of rhetoric, Porcius Latro. 
APPENDIX 


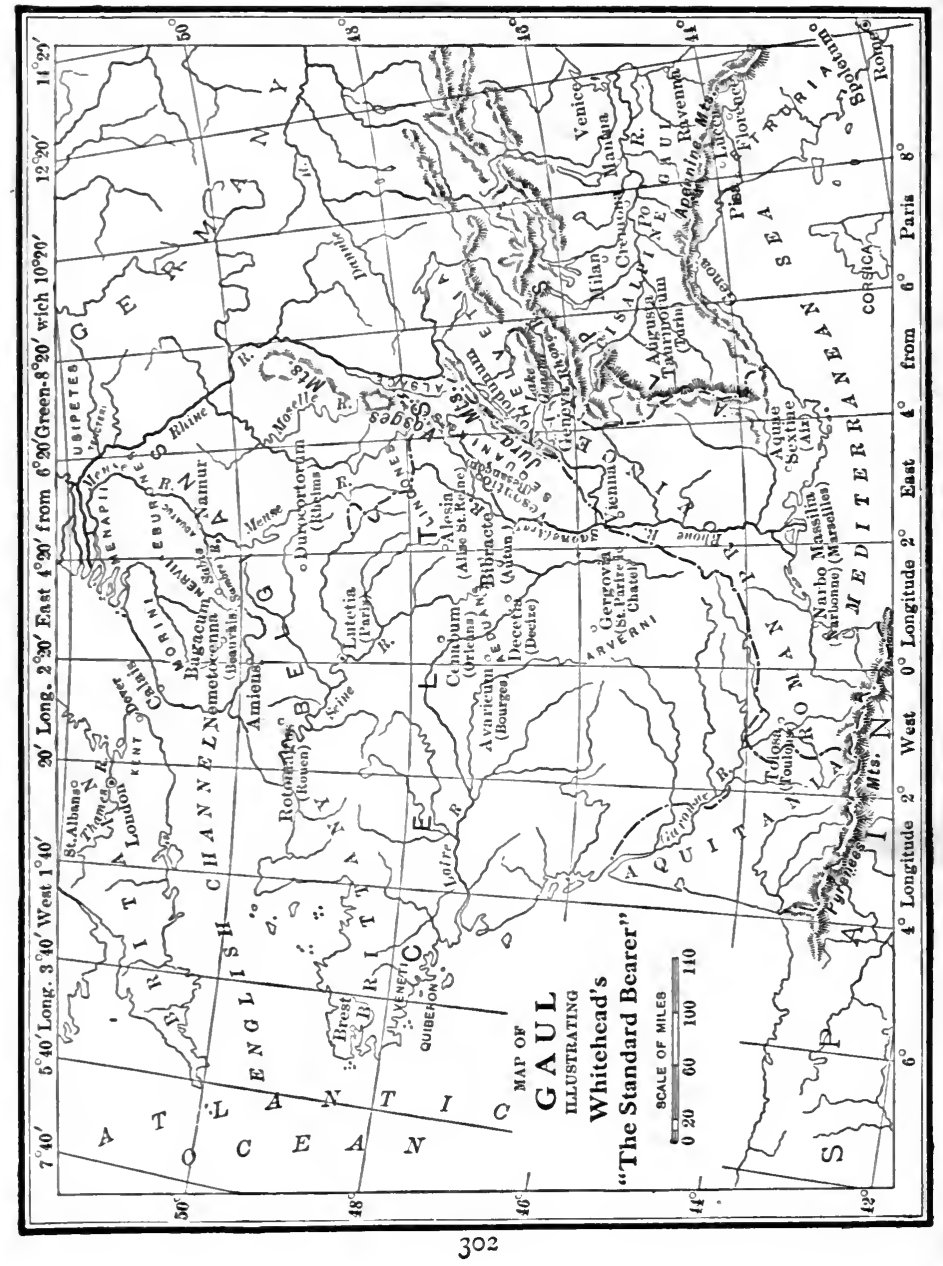




\section{PRONUNCIATION OF PROPER NAMES}

A .

Africa (ăf'-ri-cạ).

Alba (ăl'-bạ).

Alesia (a-lè'-shi-a).

Allobrogians (ăl-lō-brō'-ğĭ-ăns). Andronicus (ăn-drọ-nī'-kụs).

Antistius (an-tis'-ti-us).

Apennines (ăp'-ẹn-nines).

Ariovistus (ā-ri-ō-vis'-tus).

Arvernians (är-ver'-nĭ-ans).

Avaricum (ā-vā'-ri-cum).

\section{B}

Baculus (băc'-ŭ-lŭs).

Bagacuin (bạ-gā'-cụm).

Balbus (băl'-bus).

Bibracte (bi-brăk'-tē).

Bituriges (b̆̌-tū'-rĭ-gēs).

Boduagnotus (bod-ụ-og-nō'-tus).

Bridiga (brĭd'-ig-a).

Bujorax (bū'-jō-răx).

\section{C}

Cæsar (sē'-zạr).

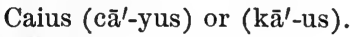

Camilla (că-mĭl'-la).

Campania (căm-pā'-ni-ạ).

Carnutes (kär'-nū-tēz).

Carvillax (cär-vil'-lăx).

Ceres (sế'-rēz).

Chæronæa (kē ro né'a a).

Chloe $\left(k \bar{k}^{\prime}{ }^{\prime}-\breve{e}\right)$.

Cimbrians (sĭm'-brĭ-ans).
Circus (sĭr'-kus).

Cisalpine (šs-ăl'-pine).

Considius (kōn-sǐd'-i-us).

Coprax (kō'-prăks).

Cornelia (cŏr-nēl'-i-a).

Cornelius (cŏr-nēl'-i-us).

Cotta (cōt'-tạ).

Coturix (cō-tu'-rix).

Crassus (crăs'-sus).

Crispina (crǐs-pī'-nạ).

Critognatus (krit-og-nā'-tus).

Crixus (crǐks'-us).

Curo (koor' -0 ).

\section{D}

Delphi (děl'-fī).

Deverra (dē-ver'-rạ).

Diviciacus (div-ǐ-shi- $\left.\bar{a}^{\prime}-k u s\right)$.

Dumnorix (dum'-nō-riks).

E

Eredox (eّ'-red-ox).

Esquiline (ěs'-kwǐ-līn).

\section{F}

Fannia (făn'-ni-ạ).

Flaminia (flăm-ĭn'-i-ạ).

Forum (fō'-rum).

G

Galba (gal'-bạ).

Gaul (gâll).

Geneva (je-nē'-va). 
Gergovia (gěr-gō $\left.\nabla^{\prime}-i-a ̣\right)$.

Gitus (git'-us).

Gracchus (grăk'-kus).

\section{H}

Hæduans (hēd'-u-ăns).

Hannibal (hăn'-ni-băl).

Hercules (hēr'-ku-lēz).

Hercynian (hẽr-sīn'-ì-ạ).

Heus (hè-us).

Hilda (hĩl'-dạ).

Hirtius (hīr'-tĭ-us).

\section{I}

Intercidona (inn-tĕr'-cìd-o'-11ạ).

\section{J}

Jugurtha (jū-gụr'-thạ).

Julius (jūl'-yus).

Jura (jūr'-ạ).

\section{L}

Labienus (lā-bi-e ét-nus).

Lanius (lăn'-i-us).

Latro (lă'-trō).

Libra (lì'-brạ).

Lingones (lĭn'gō-nēz).

Lollius (lŏl'-lĭ-us).

Longa (lŏng'-ạ).

Lucan (lūc'-ăn).

Lucius (l' $\bar{u}^{\prime}$-shius).

\section{M}

Magetobriga (ma-je-tob'-ri-ga).

Mandubians (man-dũ'-bi-ăns).

Marcus (mär'-kus).

Marian (mā'-ri-an).

Marius ( $m \bar{a}^{\prime}$-ri-us).

Mars (märs).

Matho ( $m \bar{a}^{\prime}$-tho).
Menapians (měn- $\bar{a}^{\prime}-$ pi-ans).

Mercator (mẽr-ka $\bar{a}^{\prime}$-tor).

Metius (mét-shius).

Meturio (mět-̄̄'-ri-ō).

Mithridates (mïth-ri-dā'-tēz).

Moselle (mōs-ěl' ${ }^{\prime}$ ).

Mutilus (mū' $\bar{u}^{\prime}$ tr̆-lus).

N

Neptune (něp'-tūne).

Nervians (nẽr'-vi-ans).

O

Ognius (ŏg'-nĭ-us).

Oppius (ŏp'-pi-us).

Ouadd ( $\left.\overline{o u}^{\prime}-\mathrm{a} d\right)$.

$\mathbf{P}$

Pansa (păn'-sạ).

Parisii (păr'-ì-sì).

Parthians (pär'-thĩ-ans).

Pedius (ped'-í-us).

Phœnician (fe $\bar{e}^{\prime}-n \check{\imath}^{\prime}-$ shians).

Pilumnius (pill-um'-ni-us).

Pluto (plū'-to).

Pollux (pol'-luks).

Pomponia (pom-pót-ni-a)).

Pomponius (porn-pó'-ni-us).

Porcius (pōr's'shus).

Procillus (prō-sīl'-lus).

Publius (pub'-lì-us).

Pullo (pul'-ō).

\section{Q}

Quintus (kwin'-tus).

\section{R}

Raudian (räw'-dĭ-an).

Rauracians (râ-ră'-shans).

Ravenna (rā-věn'-nạ).

Rhine (rine). 
S

Sabis (sā'-bis).

Sannio (săn'-ň̀-ọ).

Segibo (sĕg'-ĭ-bo).

Senones (sen'-ọ-nēz).

Sequanians (se-kwăn'-yans).

Sextius (seks'-tǐ-us).

Simmias (sı̆m'-mi-as).

Spoletum (spọ-lè-'tum).

Styx (stǐks).

Sulla (sǔl'-ạ).

\section{$\mathrm{T}$}

Tarann (tăr'-ăn).

Tencteri (tengk'-tẹ̄-rī).

Teutons (t $\bar{u}^{\prime}$-tons).

Tiber (tī'ber).

Tiberius (ti-bē'-rĭ-us).
Titus (ti'-tus).

Trebonia (tre-bŏn'-ya).

Trebonius (tre-bŏn'-yus).

Tullus (tŭl'-lus).

\section{U}

Umbria (ŭm'-brĭ-ạ).

Usipites (ụ̂-sĭp'-e-tēz).

\section{V}

Venus ( $\nabla \overline{\mathrm{e}}^{\prime}$-nus).

Verbigeni ( $\left(\bar{r} r-b \mathrm{j}^{\prime}\right.$-e-nī).

Vercingetorix (

Vertico (vẽr'-tǐ-kộ).

Vesontio (ve-son'-shō).

Volcatius (vol-kā'-shus).

Vorenus (vộ'-rě'l-nus). 

$\therefore$

$$
\text { , }
$$





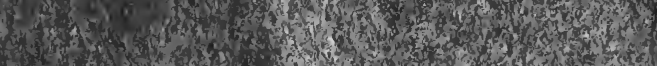

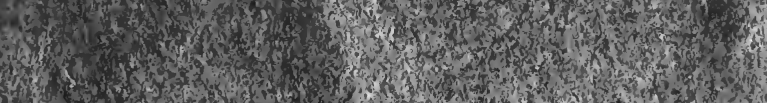

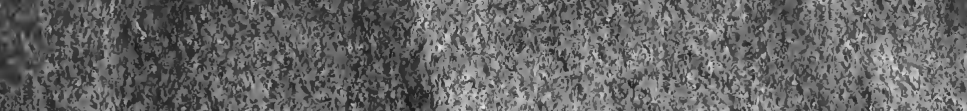

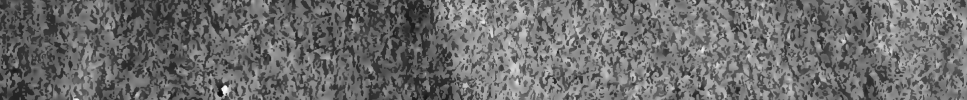

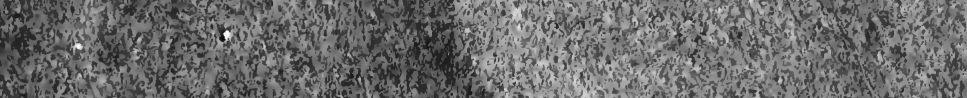

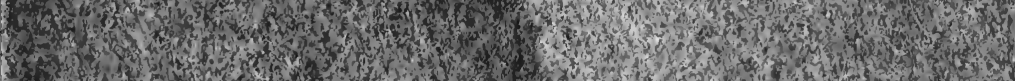

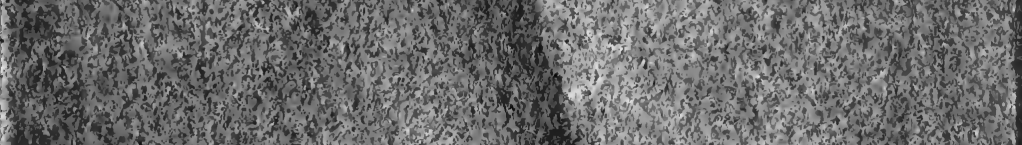
4) 3 (2)

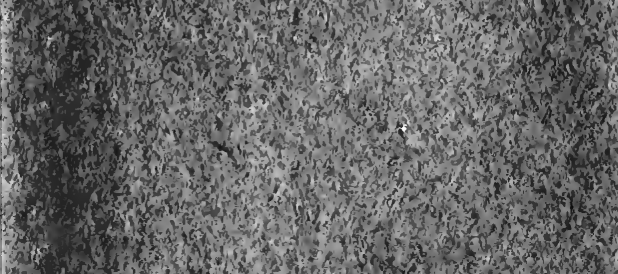

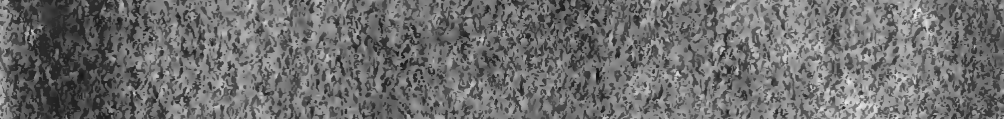

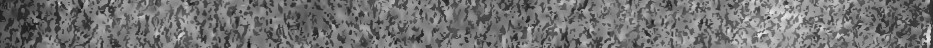

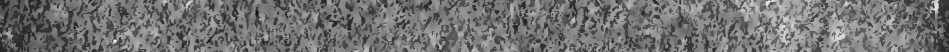
1)

H.

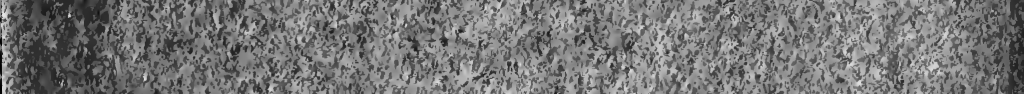
$2+20 x+2$

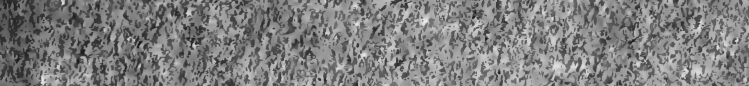

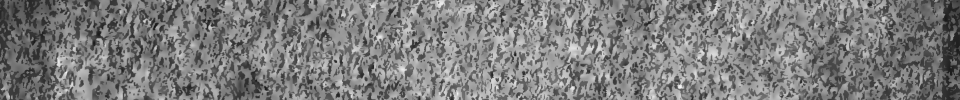
(n) Hor

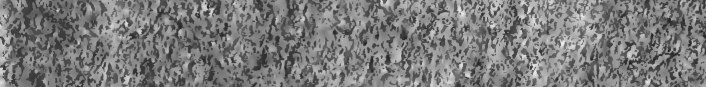

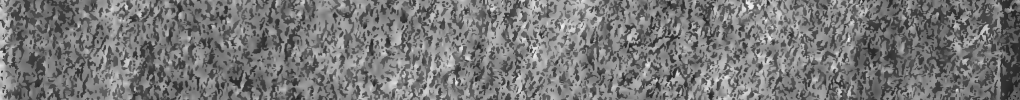

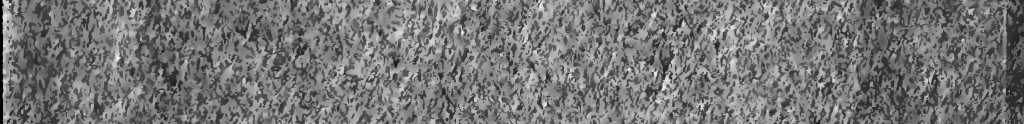
36.

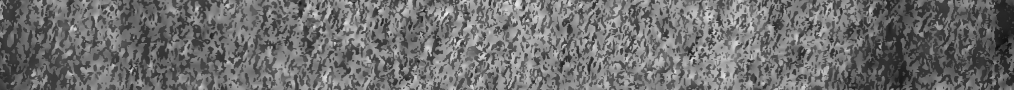


RETURN CIRCULATION DEPARTMENT

TO $\rightarrow 202$ Main Library

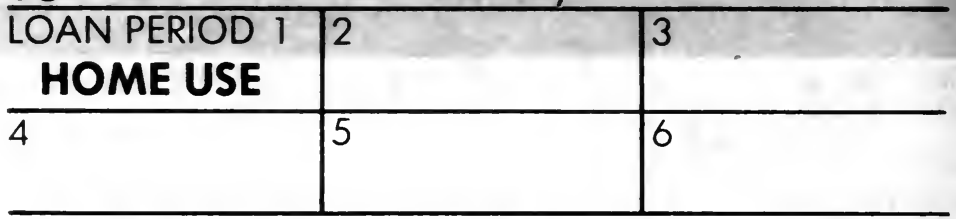

ALL BOOKS MAY BE RECALLED AFTER 7 DAYS

Renewals and Recharges may be made 4 days prior to the due date.

Books may be Renewed by calling 642-3405.

\section{DUE AS STAMPED BELOW}

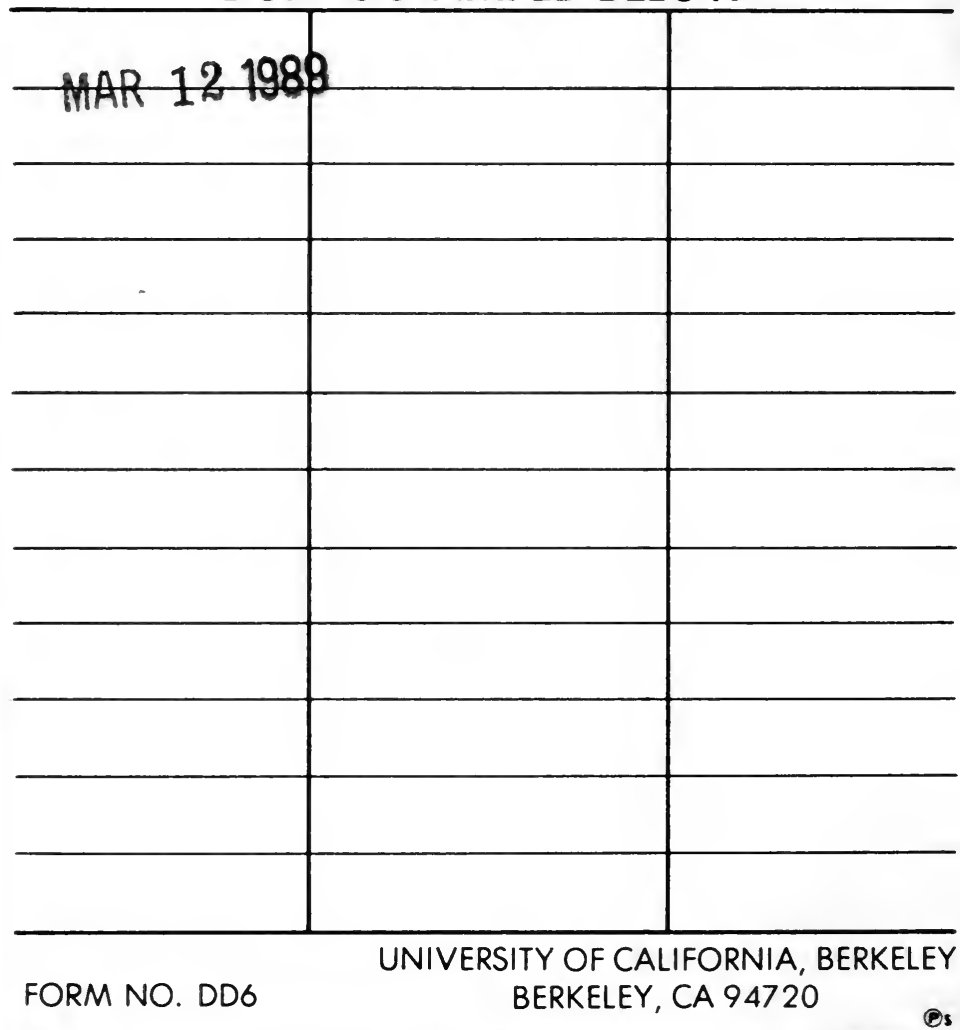




\section{YB 76488}

\section{U.C. BERKELEY LIBRARIES}

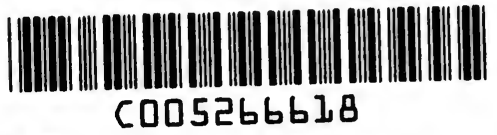

THE UNIVERSITY OF CALIFORNIA LIBRARY 
